UNIVERSIDADE DE SÃO PAULO

FACULDADE DE FILOSOFIA, LETRAS E CIÊNCIAS HUMANAS

PROGRAMA DE PÓS-GRADUAÇÃO EM GEOGRAFIA HUMANA

MARCELO GONÇALVES DA SILVA

\title{
A TITULAÇÃO DAS TERRAS DAS COMUNIDADES TRADICIONAIS QUILOMBOLAS NO BRASIL: Análise da atuação do Estado
}

Versão Original

São Paulo 
MARCELO GONÇALVES DA SILVA

\section{A TITULAÇÃO DAS TERRAS DAS COMUNIDADES TRADICIONAIS QUILOMBOLAS NO BRASIL: Análise da atuação do Estado}

Versão Original

Tese de Doutorado apresentada ao Programa de Pós-Graduação em Geografia Humana da Faculdade de Filosofia, Letras e Ciências Humanas da Universidade de São Paulo, como parte dos requisitos para obtenção do título de Doutor em Ciências, no Programa: Geografia (Geografia Humana).

Orientadora: Prof ${ }^{\mathrm{a}}$. Dr $\stackrel{\text { a }}{ }$. Neli Aparecida de MeloThery

São Paulo 


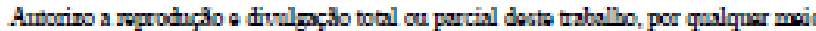
couvenciousl ou eletrtaico, pura fins do estudo e porgrisa, derde qua citod a foute.

Catalogatio na Publicachlo

Servico de Bibficteca o Documentacto

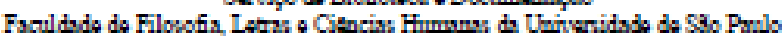

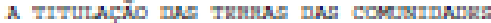

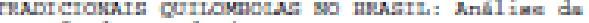

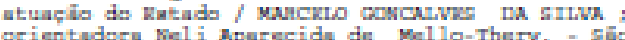
erientwderu Meli Apurecide de Malla-Thery. - gö́ Vuulo, 2017.

$310 \mathrm{E}$.

Tewe (Deutorada) - Faculdade de Vilewofia, Ietru e Ciencian Humanes da thivernidade de glo Dwala.

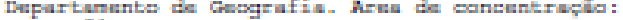
Cenogratio Hunans.

1. Cengrafia Dalítica. 2. Nolftien Dóblien. Inrritariein. A. Comuniduden Cuilombalan. I. Me11e Thery. Meli Aparweide de, erient. II. Titula.| 
SILVA, M.G. A Titulação das Terras das Comunidades Tradicionais Quilombolas no Brasil: análise da atuação do Estado. Tese de Doutorado apresentada ao Programa de Pós-Graduação em Geografia Humana da Faculdade de Filosofia, Letras e Ciências Humanas da Universidade de São Paulo, como parte dos requisitos para obtenção do título de Doutor Ciências, no Programa: Geografia (Geografia Humana).

Aprovado em:

Banca Examinadora

Prof. Dr.

Instituição:

Julgamento:

Assinatura:

Prof. Dr.

Instituição:

Julgamento:

Assinatura:

Prof. Dr.

Instituição:

Julgamento:

Assinatura:

Prof. Dr.

Instituição:

Julgamento:

Assinatura:

Prof. Dr.

Instituição:

Julgamento:

Assinatura: 

Esta obra é dedicada ao povo quilombola do Brasil, em especial à Comunidade de Cunani... 


\section{AGRADECIMENTOS}

Agradeço primeiramente a Deus pela saúde, força de vontade e disposição para iniciar, desenvolver e concluir esse duro trabalho;

À Neli, pela oportunidade, orientação de qualidade, compreensão pela distância e até mesmo ausência em alguns momentos, pelo carinho e preocupação até mesmo com as questões pessoais que foram surgindo nesses quatro anos de jornada;

À Sônia, minha Linda, por estar sempre disposta a ajudar e por compreender a distância e ausência, mesmo estando tão perto;

Aos meus pais e irmãos, por sempre acreditarem no meu potencial e trazer uma palavra de incentivo nos momentos mais difíceis;

Ao Roni Mayer Lomba, amigo para a vida toda e para tudo na vida, que se enfiou comigo nos extremos do Amapá em busca da voz da comunidade de Cunani. Sem sua ajuda esse trabalho não teria sido possível;

Aos demais amigos do SARADAM, Kátia Rangel, Sisto Magro e Geovane Grangeiro, pelo trabalho incansável em prol do povo amapaense;

Ao Thiago Marra, Aristóteles Neto e Hélio Carlos pela amizade e companheirismo desde a época da graduação e pela ajuda prestada no desenvolver deste trabalho;

Aos amigos do INCRA, especialmente Margarida, Marcos Quadros, Mateus, Rosana, Delcio, José Marcelo e Geraldo, que sempre se mostraram solícitos a ajuda e contribuir com críticas construtivas; à Luci Espechit e Danilo Rodrigues pela compreensão e ajuda no período das disciplinas;

À Maria Helena, Lígia e Jeane que contribuíram para a revisão deste trabalho;

À Patrícia, que cuidou da pequena Alice para que eu pudesse cuidar da pesquisa, assim como os servidores/funcionários da USP cuidaram de mim para que eu cuidasse da tese;

Ao cidadão e contribuinte paulista, por tornar possível o financiamento deste curso;

Muito obrigado a todos! Não teria feito nada sem a ajuda de cada um de vocês! 
A maior característica do subdesenvolvimento não é a carência da riqueza, nem a falta dos benefícios civilizatórios, como diria Darcy Ribeiro.

Não.

A característica mais marcante do subdesenvolvimento está no desprezo à criatura e aos direitos humanos"

Orlando Villas Boas 


\section{RESUMO}

DA SILVA, M. G. A Titulação das Terras das Comunidades Tradicionais Quilombolas no Brasil: análise da atuação do Estado. 2017. 310p. Tese (Doutorado). Programa de Pós-Graduação em Geografia Humana da Faculdade de Filosofia, Letras e Ciências Humanas da Universidade de São Paulo - USP.

A Constituição Federal de 1988 inovou ao estabelecer que o Estado Brasileiro deve emitir os títulos de propriedade definitiva aos remanescentes das comunidades tradicionais quilombolas que estejam ocupando suas terras. Após quase três décadas de busca pela garantia desse direito fundamental, os resultados alcançados são insatisfatórios, haja vista que, até o fim de 2016, apenas 152 territórios foram titulados em benefício de 294 comunidades e cerca 15.910 famílias. Atualmente, apenas no INCRA, existem 1.692 processos administrativos iniciados e destes, cerca de $85 \%$ não contam sequer com o Relatório Técnico de Identificação e Delimitação (RTID) da área pleiteada concluído e publicado. O objetivo deste estudo é analisar o papel do Estado brasileiro na gestão dessas políticas, assim como avaliar a atuação dos órgãos executores dessas ações. Em estudo de caso, analisaremos as controvérsias institucionais ocasionadas pela sobreposição de interesses territoriais entre INCRA e IBAMA/ICMBio no processo de regularização do Território Quilombola de Cunani, localizada no município de Calçoene, no Estado do Amapá, que teve parte de seu território tradicional afetado pelo Parque Nacional do Cabo Orange - PNCO. Estabeleceu-se como fundamento metodológico a análise de processo e de impactos das ações enquanto política pública territorial de reparação/afirmação de diretos étnicos constitucionais, configurando-se, portanto, num tema relevante para a análise da geografia política das relações entre estado, sociedade e território. Dentre os resultados obtidos, destacamos os números que demonstram a baixa capacidade histórica do principal órgão responsável pelas ações (INCRA) em executar os recursos orçamentário-financeiros destinados à regularização das terras quilombolas, que foi de apenas $35,1 \%$ do que foi autorizado pelo Governo entre 2004 e 2015; a espacialização dos resultados alcançados pela política, que revelam uma disparidade regional das áreas tituladas e de famílias atendidas, concentrando esses índices nas regiões Norte, Nordeste e, mais recentemente, no Centro-Oeste; a análise que identifica uma instabilidade jurídicoinstitucional ocasionada pela Ação Direta de Inconstitucionalidade (ADI 3239) que contesta o Decreto Federal 4.887 de novembro de 2003; a constatação de que os interesses das comunidades tradicionais quilombolas nunca ocuparam um espaço prioritário na agenda dos sucessivos grupos políticos que se instalaram no Governo Federal e em sua base política de sustentação no Congresso Nacional. Conclui-se que a manutenção do Decreto 4.887 de novembro de 2003 sustentará a conveniente e estratégica decisão de "quem governa" de se amparar na instabilidade políticoinstitucional representada pela ADI-3239 para não se contrapor aos interesses de grupos que estão em sua base social e político-partidária (com quem se governa). Nesse contexto, a garantia do direito ao território étnico das comunidades tradicionais quilombolas prosseguirá em ritmo insatisfatório e socialmente insustentável, alcançando apenas os processos administrativos cujas demandas não suscitam custos sociais ou políticos a "quem governa", contrariando assim o dispositivo constitucional e os princípios da Administração Pública.

Palavras-chave: Geografia Política. Políticas Públicas Territoriais. Comunidades Quilombolas. 


\section{ABSTRACT}

The Federal Constitution of Brazil (1988) established that the Brazilian State should grant definitive property titles to the remnants of the traditional quilombolas communities (maroons) of the lands occupied by them, an innovative proposition. However, the results achieved are unsatisfactory after nearly three decades of guarantee of this fundamental right, since only 152 territories were titled for the benefit of 294 communities and about 15,910 families by the end of 2016. There are currently 1,692 administrative processes initiated just in INCRA and of these approximately $85 \%$ do not even have the Relatório Técnico de Identificação e Delimitação (RTID -Technical Identification and Delimitation Report) of the requested area completed and published. The objective of this research was to analyze the Brazilian State role in the management of these policies, as well as to evaluate the performance of the executing agencies of these actions. In a case study, we analyze the institutional controversies caused by the overlapping of territorial interests between INCRA and IBAMA / ICMBio in the process of regularization of the Cunani Quilombola Territory, located in the Calçoene District, in the Amapá State (Brazil) which had part of its traditional territory affected by the Parque Nacional do Cabo Orange (PNCO - Cape Orange National Park). Methodologically, the research was based on the process and impacts analysis of the actions as a territorial public policy for reparation/affirmation of ethnic constitutional rights, being therefore a relevant topic for the Political Geography analysis about relations between state, society and territory. Among the results obtained, we underline: the numbers that demonstrate the low historical capacity of the main agency responsible for actions (INCRA) to execute the financial resources destined to regularize the quilombola lands (only $35.1 \%$ from the total authorized by the Government between 2004 and 2015); the spatial dynamics of the results achieved by the policy, revealing a regional disparity between the titled areas and the families served, concentrating these indices in the North, Northeast and more recently in the Center-West of Brazil; the identification of legal and institutional instability caused by the Ação Direta de Inconstitucionalidade 3239 (Direct Unconstitutionality Action - ADI 3239) which disproves the Federal Decree 4887 (November 2003); the understanding that the interests of the traditional quilombola communities never occupied a priority topic in the successive political groups agenda settled in the Federal Government and in its political base of support in the National Congress. We conclude that the Decree 4887/2003 maintenance will support the convenient and strategic decision from "who governs" to rely on the political-institutional instability represented by ADI-3239 in order not to oppose the interests of groups that are in their social base and Political party (with which the government is made). In this context, the right guarantee to ethnic territory in traditional quilombola communities will continue to develop unsatisfactorily and socially unsustainable reaching only the administrative processes whose demands do not demand social or political costs to "who rules", thus contradicting the constitutional provision and principles of Public administration.

Keywords: Political Geography. Public territorial policies. Quilombolas Communities. 


\section{Lista de llustrações}

\section{Lista de Figuras}

Figura 01: Modelo de Análise e Avaliação de Políticas Públicas Territoriais

Figura 02: Legislação da Titulação das Terras Quilombolas: da previsão constitucional, dos decretos e da normatização (1988 a 2016).

Figura 03: Fluxograma do Processo de Titulação das Terras Quilombolas.

Fonte: DFQ/INCRA. Data não informada.

Figura 04: Localização das Comunidades Tradicionais Quilombolas com

Território Titulado pelo INCRA: 1995 a 2017.

Figura 05: Comunidades Quilombolas beneficiadas por Ações da SPU:

PPA 2012 a 2015

Figura 06: INCRA: Área Titulada por Região Administrativa: 2004 a 2015, em hectares.

Figura 07: Localização das comunidades quilombolas com territórios delimitados noAmapá: RTID Publicados e Títulos Expedidos (2016).

Figura 08: Primeira proposta de delimitação do Território Quilombola do Cunani.

Figura 09: PNCO/IBAMA: Parecer Proposta de Criação de Remanescente

Figura 10: Edital № 001/04: Reconhecimento como área de remanescente de comunidade quilombola da comunidade de Cunani.

Figura 11: ICMBio: Criação da Câmara de Conciliação.

Figura 12: Quadro Fundiário do Território Quilombola do Cunani:

Sobreposição com Glebas Cunani (GEA), PARNA Cabo Orange (ICMBio) e posseiros.

Figura 13: Tramitação do Processo Cunani/INCRA versus ICMBio no CCAF/AGU

Figura 14: Proposta aceita pelo INCRA no âmbito da CCAF

\section{Lista de Gráficos}

Gráfico 01: Distribuição regional das terras tituladas - Brasil: 1995 a 2003 
Gráfico 03: INCRA: Proporção de processos quilombolas sem RTID (\%): 2004 a 2015.

Gráfico 04: INCRA: Total de processos iniciados e processos sem nenhuma instrução, por PPA.

Gráfico 05: INCRA: Processos quilombolas por fase de instrução, 2004 a 2007

Gráfico 06: INCRA: Processos quilombolas por fase de instrução, 2008 a 2011.

Gráfico 07: INCRA: Processos quilombolas por fase de instrução, 2012 a 2015

Gráfico 08: Distribuição Regional das Terras Quilombolas Tituladas: PPA 2004-07

Gráfico 09: Titulação de terras quilombolas: Famílias Beneficiadas. PPA 2004-07

Gráfico 10: Distribuição Regional das Terras Quilombolas Tituladas: PPA 2008 a 2011

Gráfico 11: Distribuição Regional das Terras Quilombolas Tituladas: PPA 2012 a 2015

Gráfico 12: INCRA: Evolução da distribuição espacial das terras

quilombolas tituladas, por Região e PPA - 2004 a 2015

Gráfico 13: INCRA - Titulação de Terras Quilombolas: Famílias

Beneficiadas, 1995 a 2015

Gráfico 14: INCRA: Recursos Previstos, Autorizados e Pagos nas ações de titulação de terras quilombolas: 2004 a 2015. Fonte: INCRA/DFQ.

Organizado pelo autor.

Gráfico 15: DESPESAS DE CAPITAL: Recursos Previstos, Autorizados e

Pagos pelo INCRA nas ações de titulação de terras quilombolas, 2004 a 2015.

Gráfico 16: DESPESAS CORRENTES: Recursos Previstos, Autorizados e

Pagos pelo INCRA nas ações de titulação de terras quilombolas, 2004 a

2015

Gráfico 17: DESPESAS DE CAPITAL: Recursos Previstos, Autorizados e Pagos pelo INCRA nas ações de titulação de terras quilombolas, por PPA.

Gráfico 18: DESPESAS CORRENTES: Recursos Previstos, Autorizados e Pagos pelo INCRA nas ações de titulação de terras quilombolas, por PPA

Gráfico 19: DESPESAS CORRENTES: Recursos Previstos, Autorizados e

Pagos pelo INCRA nas ações de titulação de terras quilombolas - PPA 2004 a 2007

Gráfico 20: DESPESAS DE CAPITAL: Recursos Previstos, Autorizados e Pagos pelo INCRA nas ações de titulação de terras quilombolas - PPA 2004 a 2007. 
Pagos pelo INCRA nas ações de titulação de terras quilombolas - PPA 2008 a 2011.

Gráfico 22: DESPESAS DE CAPITAL: Recursos Previstos, Autorizados e Pagos pelo INCRA nas ações de titulação de terras quilombolas - PPA 2008 a 2011.

Gráfico 23: DESPESAS CORRENTES: Recursos Previstos, Autorizados e Pagos pelo INCRA nas ações de titulação de terras quilombolas - PPA 2012 a 2015.

Gráfico 24: DESPESAS DE CAPITAL: Recursos Previstos, Autorizados e

Pagos pelo INCRA nas ações de titulação de terras quilombolas - PPA 2012 a 2015

Gráfico 25: INCRA - DESPESAS CORRENTES: Valores Pagos por

Família beneficiada, por PPA.

Gráfico 26: INCRA - DESPESAS DE CAPITAL: Valores pagos por Família beneficiada, por PPA.

\section{Lista de Quadros}

Quadro 01: Proposta de Avaliação em Profundidade de Políticas Públicas de Caráter Social

Quadro 02: Participação Societal: novas relações entre Estado e Sociedade na criação de Políticas Públicas.

Quadro 03: Matriz de Análise e Avaliação de Políticas Públicas Territoriais Quilombolas

Quadro 04: Movimento Negro Brasileiro: fases e características.

Quadro 05: Áreas tituladas efetivamente destinadas às comunidades tradicionais quilombolas: 1995 a 2017

Quadro 06: Títulos outorgados pela FCP (1999 a 2003)

Quadro 07: INCRA - Titulação das terras quilombolas no Amapá: situação dos processos administrativos, 2016

Quadro 08. Ocorrência de Conflitos envolvendo comunidades quilombolas - 2014 a 2015. 


\section{SUMÁRIO}

Introdução 15

Pressupostos da Pesquisa 18

Objetivos 20

Hipóteses $\quad 20$

Aspectos Metodológicos 22

CAPÍTULO I - As Políticas Públicas e a Geografia do Poder Territorial

1.1 - A regularização de terras quilombolas: uma política pública territorial 28

1.2 - A titulação das terras quilombolas como objeto de 31 interesse da Geografia Politica

1.3 -OReconhecimento das Territorialidades Étnicas: opapel constitucional do 34 Estado Soberano

1.4 - Estado e Poder Territorial

1.5 - Titulação das terras quilombolas: parâmetros para a análise

1.6 - Matriz de Análise e Avaliação de Políticas Públicas

Territoriais

CAPÍTULO II - Terras Quilombolas: aspectos históricos da luta por um direito fundamental

2.1 - Gênese dos processos de formação das territorialidades étnicas no Brasil e continente americano

2.2 - Direitos Étnicos Territoriais das Comunidades Quilombolas 74 no Brasil: da constituição da demanda à demanda constitucional

2.3 - Movimento Negro e a Questão Quilombola

2.4 - A titulação dos territórios quilombolas: um direito constitucional

2.5 - Os quilombos e os quilombolas: o que eram e o que são? 
2.6 - Controvérsias quanto a delimitação das terras quilombolas

e as possibilidades de desapropriação

CAPÍTULO III - Regularização das Terras Quilombolas: da 108 previsão constitucional à normatização dos instrumentos administrativos

3.1 - A regulamentação do Art. 68 do ADCT: das iniciativas parlamentares à atuação do Executivo

3.2 - INCRA e FCP: disputas pelas atribuições da titulação das terras 116 quilombolas

3.3 - Os Decretos da Era Lula: Novos paradigmas para a 123 titulação das terras quilombolas. Será?

3.4 - A normatização do Decreto 4887: Do caos à prostração 130

3.5 - Uma síntese dos procedimentos administrativos para titulação de terras quilombolas

3.6 - Solução de controvérsias e impasses institucionais

CAPÍTULO IV: Titulação das terras quilombolas: análise de 152 processo e de impacto

4.1 - Análise de processo e de impacto: os resultados das ações 152 de territórios quilombolas no Brasil

4.2 - Titulação de Terras Quilombolas de 1995 a 2003: a fase Pré-Decreto 4.887 de 2003

4.3 - A Fase Pós-Decreto 4887 de Novembro de 2003 160

4.3.1 - Análise dos valores executados por família 189 beneficiada, área titulada e localização das terras quilombolas

4.3.2 - Aprofundando a análise: Fatores (geo)políticos e sua influência na titulação das terras quilombolas

4.4 - Titulação das terras quilombolas no PPA 2016-19 
CAPÍTULO V: As ações de titulação das terras quilombolas no Amapá: do reconhecimento de direitos à gestão de conflitos

5.1 - Síntese do processo histórico de formação do território amapaense: Da criação do Território Federal ao Estado do Amapá

5.2 - Titulação de terras quilombolas no Amapá: Histórico das ações e quadro atual

5.3 - Conflitos Fundiários e institucionais na titulação das terras quilombolas no Amapá

5.4 - A transferência das glebas de terras federais para o Estado do Amapá e suas consequências para as ações de titulação de terras quilombolas

CAPÍTULO VI - A Comunidade Quilombola do Cunani: da invisibilidade social à busca pelo reconhecimento de direitos

6.1 - As terras da comunidade quilombola do Cunani

6.2 - O Parque Nacional do Cabo Orange (PNCO)

6.3 - Uma sobreposição de interesses institucionais ou violência territorial?

6.4 - Da sobreposição territorial à invisibilidade social: 253 Conhecendo o processo de regularização do território da comunidade de Cunani

6.5 - Os procedimentos para solução da controvérsia: A peregrinação burocrática na CCAF

6.6 - Retomando a análise do processo administrativo INCRA

6.7 - A voz da comunidade: avaliação da atuação do poder público frente ao reconhecimento de seus direitos étnicos territoriais. 
Referências

ANEXO A

305

ANEXO B 



\section{A TITULAÇÃO DAS TERRAS \\ DAS COMUNIDADES TRADICIONAIS QUILOMBOLAS NO BRASIL:}

Análise da atuação do Estado

\section{Introdução}

Há uma canção da música sertaneja de raiz que me comove sempre que a ouço ou simplesmente me recordo de seus versos. Trata-se de "Preto Velho", composição de Belmiro, Tião Carreiro e Lourival dos Santos, ouvida sempre nas vozes inconfundíveis dos mestres Tião Carreiro e Pardinho. Transcrevo, a seguir, a poesia de sua letra:

Perguntei ao Preto Velho

Por que chora meu herói?

Preto Velho respondeu "É meu coração que dói"

Eu já fui bom candeeiro, fui carreiro e fui peão Já derrubei muito mato e já lavrei muito chão Com carinho carreguei os filhos do meu patrão

Em troca do que eu fiz, só recebi ingratidão

Perguntei ao Preto Velho Por que chora meu herói?

Preto Velho respondeu "É meu coração que dói"

Sempre chamei de senhor quem me tratou a chicote Livrei o patrão de cobra na hora de dar o bote Eu sempre fui a madeira e o patrão foi o serrote 
Sofri mais do que boi velho com a canga no cangote

Perguntei ao preto velho

Por que chora meu herói?

Preto velho respondeu

"É meu coração que dói"

Da terra eu tirei o ouro e o patrão fez seu anel Mas agora estou velho e meu patrão mais cruel

Está me mandando embora

Vou viver de déu em déu

O que me resta é esperar

A recompensa do céu

Ao conhecer esta canção, inda criança, me impressionava muito imaginar que um ser humano foi tratado com tamanho desrespeito e crueldade, seja por ser velho ou por ter a cor da pele diferente da do patrão. Obviamente que, para minha mente infantil, bastante justa e objetiva, qualquer explicação que não fosse um pedido de desculpas ao tal Preto Velho e o devido reconhecimento pelo seu esforço, não serviria. $O$ correto seria o levar volta à fazenda e Ihe prestar a devida assistência em seus últimos momentos de vida.

Conforme fui amadurecendo e conhecendo novas fontes históricas a respeito do tema da escravidão e de como o negro foi ou é integrado à sociedade brasileira, compreendi que a letra da canção Preto Velho não fala necessariamente de um único homem, descartado e relegado "à própria falta de sorte" por aqueles que exploraram suas forças à custa do chicote da escravidão e agora o querem o mais longe possível para que não atrapalhe a nova forma de explorar a fazenda, através do trabalho livre, assalariado, moderno. Preto Velho é, na verdade, o povo afrodescendente da segunda metade do Séc. XIX, prestes a ter o seu papel de mãode-obra cativa (por tantos séculos fundamentais a um regime escravocrata précapitalista) trocado pelo de sucata humana. É aquilo que já cumpriu a sua função e que passa a ser cada vez mais odiada por quem a dominava, pois ocupa espaço e traz inconvenientes. Deveria portanto ser atirada para bem longe para que não se 
transformasse em problemas maiores ou, tal qual o destino do velho da canção, que vivesse de de déu em déu, esperando a recompensa do céu.

Porém, tão significativa quanto essa descoberta foi a de que todo esse vergonhoso processo foi instituído e até financiado pelo próprio Estado Brasileiro, seja aquele do Segundo Reinado, ainda no período Imperial, seja por aquele da Primeira República. Em nenhuma dessas antigas fases do Estado Brasileiro, os gestores das políticas públicas nunca se preocuparam em promover a integração social e econômica dos negros recém-libertos. Ao contrário, trataram de estimular, em políticas oficiais, o simultâneo processo de "embranquecimento" da população brasileira e a importação de mão-de-obra assalariada da Europa. Não bastasse atirar o negro recém-liberto à própria sorte, a Lei de Terras de 1850 havia ainda retirado a possibilidade de regularização fundiária de terras devolutas ou públicas pela simples ocupação e cultivo, restando aos negros pagar em dinheiro ao Estado pela terra devoluta que por ventura viessem a ocupar.

Obviamente que esta não foi uma alternativa que estava ao alcance dessas famílias e, assim, foram habitar as favelas e morros das grandes cidades ou, no caso daquelas famílias expulsas das grandes fazendas de exploração de café ou cana, para as áreas inóspitas, remotas e insalubres do "sertão" ou das "florestas" brasileiras, em busca de e refúgio e sobrevivência.

Foi praticamente um século depois da Abolição da Escravatura (1888) e da Proclamação da República (1889) que o Estado Brasileiro reconheceu, de forma discreta e sutil, a violência moral e territorial a que haviam sido acometidos esses povos. Foi quando promulgou, na Carta Magna de 1988, um artigo que tratava do reconhecimento do direito fundiário dos descendentes dos escravos e quilombolas sobre as terras ocupadas historicamente por eles, tal qual a do Preto Velho cantado nos versos da música caipira.

Este reconhecimento está previsto especialmente no Artigo 68 do Ato das Disposições Constitucionais Transitórias (ADCT) da Constituição Federal de 1988, e trata das ações de titulação das terras quilombolas. Estas ações são apropriadas neste estudo em duas perspectivas diferentes, porém complementares: primeiro, como uma política pública territorial e, por outro lado, como uma política de reparação dos direitos étnicos coletivos dessas populações tradicionais afrodescendentes. Em conjunto, visam garantir, mesmo que tardiamente, a 
segurança fundiária das áreas ocupadas por esses povos e fornecer condições sustentáveis para sua reprodução material e cultural.

Art. 68. Aos remanescentes das comunidades dos quilombos que estejam ocupando suas terras é reconhecida a propriedade definitiva, devendo o Estado emitir-lhes os títulos respectivos. (BRASIL: Constituição Federal)

O reconhecimento pelo Estado brasileiro do direito dessas populações sobre as terras tradicionalmente ocupadas e a consequente emissão dos títulos definitivos de propriedade é compreendido no âmbito deste estudo como o fundamento básico para o alcance de outros direitos fundamentais das famílias quilombolas, como a melhoria dos seus índices de desenvolvimento humano e social, da autonomia de suas decisões sobre seus modos de vida, do respeito às suas territorialidades, bem como da possibilidade de sua emancipação, enquanto atores políticos e sociais reivindicadores e conquistadores de seus direitos.

Contudo, o atendimento às demandas de titulação das terras das comunidades tradicionais quilombolas ensejam ações do poder público que resultam, de acordo com as características geográficas da região em que está inserida, na criação ou agravamento de impasses políticos, tensões sociais e conflitos fundiários, bem como de impasses e controvérsias institucionais no seio da própria Administração Pública. Cabe, portanto, ao Poder Público, gerir os interesses diversos que obstacularizam a efetivação das ações de titulação dessas terras, especialmente nas situações em que certos setores da sociedade têm suas demandas e interesses impactados por essas ações.

\section{Pressupostos da Pesquisa}

O pressuposto básico desta pesquisa se fundamenta na compreensão de que as ações de regularização das terras quilombolas, que tem por objetivo final a outorga dos títulos de propriedade das terras que ocupam, constituem-se como direitos humanos legítimos das comunidades tradicionais quilombolas e devem ser tomadas pela União como demandas urgentes, em busca da efetivação de direitos 
fundamentais que, historicamente, não foram garantidos a essas comunidades devido, especialmente, a ineficiência ou omissão do próprio Estado em cumprir com suas obrigações constitucionais.

Fundamento-me ainda na assertiva de que as demandas quilombolas pela regularização de suas ocupações devem ser compreendidas como produto de processos pretéritos de intervenção territorial promovidos ou estimulados pelo Estado brasileiro, desde os projetos geopoliticamente estratégicos de colonização e ocupação do território nacional, especialmente para a ocupação da porção centrooeste-norte do Brasil (KOHLHEPP, 2002). O Estado, nesse contexto compreendido como o vetor da modernização e planejamento do território, não incluiu as populações tradicionais quilombolas e as suas identidades étnico-territoriais em seus projetos estratégicos, aumentando significativamente as pressões exercidas pelos atores não-quilombolas (pequenos, médios e grandes agricultores e pecuaristas, ambientalistas, corporações do segmento minerário, imobiliário etc.) sobre essas comunidades, que resultaram, em muitos casos, em tensões, conflitos e perda paulatina de frações de suas terras, desterritorializando parcial ou integralmente as comunidades.

Em outro contexto, também fundamento minha análise na consideração de que, uma vez iniciado o processo administrativo de regularização das terras quilombolas, são gerados impactos significativos no uso político e econômico do território, nas estratégias de intervenção na estrutura, no ordenamento e desenvolvimento territorial, em múltiplas escalas (RUCKERT, 2010), ocasionando por vezes disputas geopolíticas caracterizadas pelos conflitos que contrapõem os interesses de setores da sociedade que sustentam grupos político-partidários eleitos para exercer a função de discricionariedade e de controle da agenda do poder público.

Admito que esse processo desencadeie alterações significativas nas relações de apropriação do espaço geográfico por grupos políticos diversos e nas suas interações e apropriações do território. É, portanto, uma investigação relevante para a ciência geográfica, especialmente no campo da Geografia Política, no contexto da abordagem das relações de poder e atuação do Estado e dos demais atores políticos na garantia dos direitos étnicos territoriais. 


\section{Objetivos}

O objetivo central da pesquisa é analisar a atuação do Estado brasileiro na execução das ações de titulação das terras quilombolas desde sua previsão no texto constitucional de 1988. Dentre os objetivos específicos, destacamos:

- Compreender o processo histórico da luta pela garantia dos direitos fundamentais dos povos quilombolas na legislação brasileira, especialmente da regularização fundiária de suas terras, notadamente, a partir da atuação dos grupos de pressão política e social;

- Identificar e analisar as iniciativas do Parlamento e do Executivo brasileiro na regulamentação desse dispositivo constitucional;

- Analisar os resultados alcançados na efetivação das ações de titulação das terras quilombolas, bem como os impactos ocasionados por esse processo, a partir da Constituição de 1988;

- Avaliar a atuação do estado na gestão dos impasses, tensões e conflitos, bem como das controvérsias institucionais instauradas no seio da própria administração pública federal na condução dos processos de titulação das terras quilombolas. Considera-se para avaliar tal atuação, um estudo de caso que aborda o processo de titulação das terras da Comunidade Quilombola do Cunani, localizada no estado do Amapá, extremo norte do Brasil.

\section{Hipóteses}

A hipótese central, que subsidia as discussões apresentadas nesse trabalho, fundamentou-se na premissa de que as ações de titulação de terras quilombolas, apesar de abrigadas pelo texto constitucional desde 1988, são regulamentadas e sustentadas por uma base político-institucional extremamente frágil, tornando-as sensíveis às conveniências políticas e ao posicionamento ideológico-partidário dos grupos que se alternam na chefia do Poder Executivo. 
Isso explicaria, em grande medida, os cenários de instabilidade políticoadministrativa a que estas ações são expostas sistematicamente, bem como: a) as disparidades regionais nos resultados obtidos (quantidade de títulos expedidos, de terras tituladas e famílias atendidas por região administrativa e unidade federativa);

b) a baixa eficiência dos órgãos executores dessas ações - Fundação Cultural Palmares (FCP) e Instituto Nacional de Colonização e Reforma Agrária (INCRA) - na execução dos recursos orçamentários e financeiros direcionados a essas ações; c) o extenso, moroso e complexo rito burocrático para a elaboração dos Relatórios Técnicos de Identificação e Delimitação (RTID) dos territórios quilombolas.

Deve ser ressaltada ainda uma possível relação entre os baixos índices de eficiência e eficácia das ações com o baixo investimento público na infraestrutura operacional de apoio aos trabalhos técnicos relacionados à ação e na capacitação e qualificação do reduzido quadro de servidores lotados, nos serviços de regularização dos territórios quilombolas do INCRA.

Nesse contexto, as hipóteses confirmadas no decorrer dessa pesquisa foram elencadas nos seguintes termos:

- Os resultados das ações de regularização das terras quilombolas não ocorrem num ritmo suficientemente satisfatório para garantir a segurança fundiária das comunidades quilombolas, fazendo com que o passivo administrativo para titulação de terras adquira dimensões políticas e socialmente insustentáveis;

- As dificuldades, encontradas pela Administração Pública Federal, especialmente o INCRA, para realizar a titulação das terras quilombolas geram um cenário de insegurança fundiária para as comunidades tradicionais e as áreas de entorno do território pleiteado, o que converge para o agravamento de tensões sociais e conflitos fundiários, territoriais e sobreposições de interesses institucionais, que comprometem não apenas os direitos fundamentais dessas populações tradicionais, mas também de outros setores da sociedade em geral.

- A manutenção da sistemática burocrática e metodológica prevista pela legislação vigente, especialmente no que se refere à necessidade de elaboração de relatórios antropológicos como peça dos relatórios de 
identificação e delimitação da área pleiteada pelas comunidades, bem como a excessiva tutela do Estado sobre as decisões referentes a pontos sensíveis da condução dessas ações, como a ressignificação do termo quilombo, o conceito de terras ocupadas e a obrigatória cláusula de coletividade do domínio das terras do título outorgado, impedem a criação das condições necessárias ao destravamento das titulações de terras quilombolas.

- As sucessivas tentativas de regulamentação do Art. 68 dos ADCT e da normatização dos trabalhos técnicos, no âmbito do INCRA, condenou as demandas fundiárias das comunidades quilombolas a estarem vinculadas, na prática, a uma política de Governo, refém da orientação ideológica-partidária que o fundamenta e das necessidades de acomodação de interesses diversos na agenda pública, distanciando essas demandas das políticas de Estado.

Foi parcialmente refutada a hipótese de que a fragilidade jurídico-institucional gerada pela contestação do Decreto 4.887 de 2003, por meio da ADI 3.239, no Supremo Tribunal Federal, explicaria o fracasso das ações de titulação das terras quilombolas. O que se constatou é que os grupos que ocuparam e ocupam o Governo Federal e os cargos decisórios do INCRA desde 2004 se utilizaram (e ainda se utilizam) estrategicamente do argumento da existência da ADI 3.239 para se justificar em relação à morosidade com que os processos administrativos se arrastam na autarquia. Se "rendem" à ameaça representada pela ADI 3.239 para, sob esse pretexto, não se contraporem efetivamente ao interesse de grupos de pressão e de interesses que são priorizados pelo Governo como, por exemplo, os setores do agronegócio, minerários, ambientalistas, dentre outros.

\section{Aspectos Metodológicos}

A investigação, que fundamenta a realização deste trabalho, estabeleceu-se com vistas à criação de um aporte metodológico que permitisse aprofundar a análise das estratégias de controle da agenda pública, das formas de gestão das intervenções operadas pelo poder público em relação ao atendimento das 
demandas quilombolas, assim como para a superação dos conflitos fundiários e institucionais identificados no processo. Nesse contexto, a proposta metodológica de Rodrigues (2008), denominada avaliação de políticas públicas em profundidade ou em aprofundamento, foi admitida como parâmetro metodológico inicial para o desenvolvimento dos procedimentos de investigação, uma vez que as ações de titulação de terras quilombolas requerem um tipo de abordagem para além da simples análise de resultados obtidos em determinados períodos. Essa discussão será retomada com mais detalhamento no decorrer do Capítulo 01, que versará, dentre outros temas, sobre os parâmetros para a análise das ações, objeto desse estudo.

Para o cumprimento dos objetivos propostos, optou-se por uma abordagem metodológica descritivo-analítica do processo histórico que convergiu no reconhecimento constitucional das demandas fundiárias das populações quilombolas e para sua regulamentação infraconstitucional, dos impactos da execução dessas ações nos âmbitos da política fundiária nacional e regional, bem como uma análise da gestão institucional dos recursos orçamentários e financeiros e das estratégias de atuação do órgão federal (INCRA). Por fim, realizou-se um estudo de caso, para confirmar ou refutar algumas hipóteses desenvolvidas no decorrer da pesquisa. Com vistas ao cumprimento dessas demandas, foram executados os seguintes procedimentos:

- Revisão da literatura científica dedicada à análise e avaliação de políticas públicas, assim como das ações de titulação das terras quilombolas no Brasil, destacando aqueles trabalhos mais relevantes para o nosso objeto central de estudo. Optou-se por realizar essa revisão ao longo dos capítulos, à medida que os temas pertinentes a tais contribuições eram abordados;

- Revisão dos dispositivos supra e infraconstitucionais que fundamentam as ações de titulação das terras quilombolas;

- Identificação, classificação e análise de documentos e dados contidos nos processos administrativos e/ou de relatórios técnicos de gestão disponibilizados pelo poder público. Esse material foi posteriormente sistematizado pelo autor com vistas à elaboração de gráficos, quadros, figuras e citações textuais, que se encontram por sua vez distribuídas no decorrer 
dos capítulos. Todas as informações que sustentaram a elaboração desses instrumentos analíticos foram sistematizadas de forma sintética e estão disponíveis para consulta como anexo a esse trabalho.

- Análise de eficiência e impacto das ações de regularização de terras quilombolas, estabelecendo critérios objetivos para a identificação dos possíveis gargalos administrativos, políticos e sociais, que dificultam a execução dessas ações.

- Coleta de dados primários, junto a atores sociopolíticos envolvidos diretamente nas ações de titulação das terras quilombolas, via entrevista semiestruturada, que possibilitaram a discussão, a respeito das hipóteses desenvolvidas no decorrer da pesquisa, bem como da realização do estudo de caso na Comunidade Quilombola de Cunani, localizada no município de Calçoene, no norte do estado do Amapá, região Norte do Brasil.

A partir da experiência do pesquisador como servidor do INCRA, da produção e sistematização dos dados primários e da revisão bibliográfica e processual acima descrita, criaram-se condições para a realização da análise de processo, capaz de integrar os elementos da análise prática e teórico-conceitual com os dados de implementação física (número de títulos expedidos, de famílias atendidas e área titulada), orçamentária e financeira das ações de regularização de terras quilombolas, obtidas junto a sítios eletrônicos oficiais, relatórios de gestão e prestações de contas anuais disponibilizadas pelas autarquias federais (INCRA), ou mesmo via solicitação pessoal, quando das visitas técnicas realizadas.

Essa gama de informações e dados permitiu a comparação de recursos orçamentários e financeiros (planejados, autorizados e executados) com os resultados obtidos por período Planos Plurianuais (PPA's) e Leis Orçamentárias Anuais (LOA), assim como estabelecer a distribuição espacial dos resultados obtidos pelas unidades federativas e regiões administrativas do Brasil.

No decorrer do trabalho de campo, realizado, entre os dias 22 de março e 01 de abril de 2017, quando este pesquisador se deslocou até o estado do Amapá, realizaram-se visitas técnicas para coleta de depoimentos de agentes públicos, lideranças dos movimentos quilombolas e de entidades civis que atuam na questão quilombola, bem como para acesso a documentos oficiais (processos 
administrativos), disponibilizados pela Superintendência Regional do INCRA no Amapá.

Como descrito anteriormente, os procedimentos para coleta de dados primários fundamentou-se na necessidade de reconhecer a percepção dos vários atores políticos e sociais a respeito das ações de titulação das terras quilombolas no Brasil e, mais especificamente, no estado do Amapá. Nesse sentido, foram utilizadas ferramentas multimétodos, conciliando elementos quantitativos e qualitativos ao levantamento, especialmente no que se refere aos questionários de pesquisa e guias de entrevista - Survey. Essa técnica de coleta de dados primários está em acordo com o preconizado por Freitas et. al (2000), que afirma

Os métodos de pesquisa podem ser quantitativos (survey, experimento etc.) ou qualitativos (estudo de caso, focus group etc.), devendo sua escolha estar associada aos objetivos da pesquisa. Ambos os tipos possuem, naturalmente, vantagens e desvantagens. Não há obrigação alguma de se eleger apenas um método; cada desenho de pesquisa ou investigação pode fazer uso de diferentes métodos de forma combinada, o que se denomina de multimétodo, ou seja, aliando o qualitativo ao quantitativo (e não só tendo mais de uma fonte de coleta de dados. (FREITAS et al, 2000, p. 105)

No que se refere à escolha da ferramenta tipo survey, Freitas et al. (2000) declara ainda que pode ser descrita como a obtenção de dados ou informações sobre características, ações ou opiniões de determinado grupo de pessoas ou a partir do representante de uma população-alvo, por meio de um instrumento de pesquisa (normalmente um questionário).

Tal descrição alinha-se a diversos objetivos propostos por essa pesquisa, especialmente àqueles voltados à análise crítica de: a) desempenho e impacto das ações de regularização de territórios quilombolas, b) atuação das instituições públicas (especialmente o INCRA e ICMBio) na condução desses processos; c) obstáculos impostos pelo regulamento jurídico-administrativo (especialmente a partir do Decreto 4887 de 2003 e nas consequentes Instruções Normativas do INCRA), d) mecanismos de melhoria do desempenho das ações de titulação.

Considerando o que é preconizado por Freitas et al (2000), foi realizado um pré-teste com o objetivo de refinar o instrumento, visando a garantia de que ele 
realmente medirá aquilo a que se propõe. Para Gil (1991), devem ser consideradas no Pré-Teste os seguintes aspectos: clareza e precisão dos termos; quantidade de perguntas, forma das perguntas, ordem das perguntas e introdução. Nesse momento, foram observadas, portanto, a coerência e clareza das proposições, se as respostas obtidas não indicavam dificuldades quanto ao conteúdo das indagações e se a disposição e apresentação do formulário garantiriam uma abordagem satisfatoriamente detalhada e coerente com os objetivos dessa pesquisa.

Assim, foram realizadas entrevistas semiestruturadas (com a devida autorização do respondente para a gravação do áudio) para um registro detalhado de informações e opiniões críticas relativas a alguns aspectos inerentes: a) ao panorama geral das ações de regularização de territórios quilombolas no Brasil e no Amapá; b) às dificuldades enfrentadas para a emissão dos títulos de domínio; c) à avaliação da atuação do poder público na gestão dos conflitos que envolvem a efetivação dos direitos das comunidades quilombolas. O perfil almejado para a seleção dos respondentes dessa etapa da pesquisa privilegiou aqueles atores que desempenharam papéis estratégicos ou de destaque no decorrer da implementação das ações, seja como gestores públicos, pesquisadores, lideranças das comunidades quilombolas e dos movimentos civis organizados.

Deve-se ressaltar que, em todas as etapas da coleta de dados, foram oferecidas a confidencialidade das respostas aos colaboradores, mas todos abriram mão desse expediente, conforme pode ser constatado nos próprios registros de áudio. Também foi garantido aos respondentes que suas respostas e opiniões seriam utilizadas única e exclusivamente no âmbito científico e acadêmico, o que pode ser constatado nos registros de áudio das entrevistas.

Estruturamos a elaboração desta monografia em 06 capítulos. O primeiro trata, em termos gerais, da apresentação do tema enquanto objeto de análise relevante para a Geografia Política e a análise das Políticas Públicas Territoriais, além de propor uma matriz para a análise das ações de titulação das terras quilombolas. O segundo se dedica ao debate dos principais aspectos históricos que estão na gênese das demandas quilombolas e do processo que convergiu para a inserção dos direitos territoriais destas comunidades étnicas tradicionais no texto constitucional de 1988. O terceiro capítulo identifica, nas relações políticas e institucionais desencadeadas pelo processo dinâmico de regulamentação desses 
direitos étnicos territoriais e da disputa interinstitucional travada entre INCRA e FCP por estas atribuições, alguns fatores para a análise geopolítica da questão quilombola no Brasil, sobretudo a partir da perspectiva da atuação do próprio Estado e Governo ("quem governa"). O quarto capítulo é dedicado à realização de uma análise de impacto e de processo das ações de titulação das terras quilombolas no Brasil, explorando os dados orçamentários e financeiros destinados à essas ações e comparando-os com os resultados obtidos e com a espacialização destes resultados pelo território brasileiro, buscando compreender os processos e os paradigmas adotados pela Governo por período. O capítulo seguinte trata da análise da titulação das terras quilombolas no Amapá e, como fundamento para a compreensão deste quadro, recupera o histórico recente de formação do território amapaense e de como os processos políticos influenciam na gestão daquele território e das demandas das comunidades tradicionais quilombolas naquele estado. O sexto e último capítulo é dedicado à análise do caso da Comunidade Quilombola do Cunani, localizada no extremo norte do Amapá, cujo território tradicional foi decretado em 1980 como Parque Nacional do Cabo Orange (PNCO), atualmente sob gestão do Instituto Chico Mendes da Biodiversidade (ICMBio), o que tem representado um entrave para o reconhecimento e titulação das terras tradicionais da comunidade como território quilombola pelo Estado Brasileiro. 


\section{CAPÍTULO I - As Políticas Públicas e a Geografia do Poder Territorial}

Compreender as políticas públicas de reconhecimento das territorialidades étnicas e titulação de seus limites territoriais enquanto instrumento constitucional de intervenção do estado no território e, por consequência, da constituição de uma nova geografia do poder territorial nas escalas locais e/ou regionais é o objetivo principal deste capítulo. É nesse contexto que analisaremos o papel do Estado Brasileiro na gestão das políticas públicas territoriais e como isso impacta as relações de poder entre os diversos grupos sociais e de interesse, e destes com o próprio EstadoGoverno, além de tomá-las como prerrogativa para a compreensão dos desafios enfrentados para a garantia dos direitos étnicos territoriais das comunidades quilombolas. Outro objetivo é propor uma matriz de avaliação dessas políticas que permita sistematizar esta investigação, possibilitando a realização de uma análise em profundidade dessas ações à luz da análise e avaliação das políticas públicas territoriais.

\section{1 - A regularização de terras quilombolas: uma política pública territorial}

A regularização das terras quilombolas é uma ação executada pelo Governo Federal e por algumas unidades federativas brasileiras que tem como objetivo principal emitir títulos de propriedade definitiva das terras ocupadas pelos remanescentes (ou descendentes) dos quilombos. São várias as questões jurídicas, filosóficas, políticas, conceituais e até semânticas que pairam sobre o tema, que tratam desde a definição do significado do termo quilombo, da identificação de quem seriam os remanescentes dessas comunidades e da metodologia que deve ser observada para a identificação desses povos e para a delimitação e destinação dos territórios reivindicados.

O marco legal para a execução dessas ações pelo Estado Brasileiro só veio a ser instituído no ordenamento jurídico brasileiro a partir da Constituição Federal de 
1988, uma vez que o Artigo 68 do Ato das Disposições Constitucionais Transitórias asseverou que

Art. 68. Aos remanescentes das comunidades dos quilombos que estejam ocupando suas terras é reconhecida a propriedade definitiva, devendo o Estado emitir-lhes os títulos respectivos. (BRASIL: Constituição Federal)

O texto constitucional deixa clara a obrigação do Estado Brasileiro em reconhecer a propriedade e emitir os títulos das terras ocupadas pelos descendentes das comunidades quilombolas. Contudo, a execução dessas ações envolve uma série de intervenções que tem o potencial de provocar impactos consideráveis no quadro fundiário e no ordenamento territorial em diversas regiões, seja no campo ou na cidade, seja nas áreas mais remotas ou mesmo naquelas de grande valorização para os diversos setores da política e economia nacional, como agropecuária, mineração, mercado imobiliário, turismo e movimentos ambientalistas e o próprio Estado Brasileiro.

Elementos como esses fazem das ações de titulação de terras quilombolas uma das mais importantes políticas territoriais executadas pelo Estado Brasileiro nas últimas décadas, não apenas pela tardia oportunidade de reparação do direito à segurança fundiária que foi historicamente negado a esses povos, mas também pela capacidade de desencadear tensões, impasses e conflitos territoriais que têm o Estado brasileiro como mediador, gestor ou mesmo como provedor desses eventos.

No contexto das ações de titulação de terras quilombolas enquanto instrumento de intervenção territorial apropriado pelo Estado, é importante destacar que a abordagem geográfica como uma ferramenta de análise extremamente relevante para a compreensão dos fenômenos que são desencadeadas a partir delas, uma vez que, conforme salienta Dos Anjos (2006, p. 339)

A geografia é a ciência do território e este componente básico continua sendo o melhor instrumento de observação do que aconteceu - porque apresenta as marcas da historicidade espacial do que está acontecendo - porque, tem registrado os agentes que atuam na configuração geográfica atual - e do que pode acontecer, - porque é possível capturar as linhas de forças da 
dinâmica territorial e apontar as possibilidades da estrutura do espaço no futuro próximo. Não podemos perder de vista que é essa a área do conhecimento que tem o compromisso de tornar o mundo e suas dinâmicas compreensíveis para a sociedade, de dar explicações para as transformações territoriais e de apontar soluções para uma melhor organização do espaço. A geografia é, portanto, uma disciplina fundamental na formação da cidadania do povo brasileiro, que apresenta uma heterogeneidade singular na sua composição étnica, socioeconômica e na distribuição espacial.

Tendo como plano de fundo a fala de Dos Anjos (2006), compreendemos que a análise dos processos vinculados às políticas territoriais, inclusive as voltadas às demandas étnicas das comunidades tradicionais, dentre elas as quilombolas, se constituem num objeto de extrema relevância para o campo de estudos do campo da Geografia Política e da Geopolítica. Isto se dá, sobretudo, pela compreensão de que o território é objeto e meio do poder do Estado (COSTA, 1992), ao passo que para Ruckert (2010, p.18) as políticas territoriais são entendidas como o campo das ações emanadas dos poderes centrais, regionais e locais sobre os diversos territórios. São fundamentos, portanto, que subsidiam a análise das políticas públicas territoriais como instrumentos de poder territorial típico do Estado e, portanto, objeto relevante para a análise aqui proposta

A abordagem das políticas territoriais em Geografia Política é realizada adotando-se a análise dos usos políticos e econômicos do território, isto é, as estratégias de intervenção na estrutura, no ordenamento e no desenvolvimento territorial, em múltiplas escalas. (RUCKERT, 2010, p. 17)

As políticas territoriais podem ser assumidas, portanto, como o fio condutor para a compreensão dos processos de intervenção do Estado na gestão do ordenamento territorial e das redes de poder, no sentido de que se constituem na materialização da vontade e da capacidade do Estado sobre o território (territorialidade estatal). É, por consequência, o ponto chave para que se realize a avaliação do papel das instituições oficiais (aparato estatal) que exercem o poder de intervenção territorial emanado da legitimação constitucional do Estado. 


\section{2 - A titulação das terras quilombolas como objeto de interesse da Geografia Politica}

Apesar de os estudos atuais no campo da Geografia Política e da Geopolítica se dedicarem, dentre outros temas, ao estudo da lógica de apropriação territorial resultante das relações entre estados e entre estados e sociedades, há uma grande carência de estudos voltados à análise direta de processo e de impactos das relações de poder desencadeadas pela efetivação das ações de titulação das terras quilombolas. Compreendemos, ainda, que o reconhecimento da nova geografia do poder local ou regional vinculada à titulação das terras quilombolas trás consigo a oportunidade de reconhecimento da dimensão e relevância destes processos enquanto vetores de novos modelos de disputas sociais e, não obstante, da emergência de um novo redimensionamento e/ou recategorização dos conflitos de interesses territorializados, pautados especialmente a partir do reconhecimento constitucional das territorialidades étnicas. Esta análise pode se dar em recortes no tempo e no espaço que possibilitem a delimitação das características dos fenômenos e dimensionamento dos impactos nos processos fundiários locais ou regionais, por um lado, mas também na consideração da sua importância para o surgimento de impasses institucionais e institucionalizados no seio do próprio aparato estatal, por outro.

O que se pretende é estabelecer que a temática que denomino, no âmbito dessa pesquisa, como políticas públicas de reconhecimento das territorialidades étnicas, pode ser realizada a partir da análise das relações que caracterizam uma nova geografia do poder territorial desencadeada pelas ações de regularização das terras quilombolas em diversas escalas de análise. Em outras palavras, trata-se da análise de fatos e fenômenos objeto de interesse da abordagem geopolítica.

É importante destaca que, atualmente, os estudos relacionados à Geopolítica, seja no âmbito da Geografia ou de outras ciências, como as Relações Internacionais, Ciência Política, Direito, Economia, História, dentre outras, abordam fenômenos políticos que extrapolam o objeto do pensamento geopolítico clássico. Compreendem também como interesse dessa Nova Geopolítica (Vesentini, 2003) os processos de disputa de poder e território experimentados pelos atores políticos 
além dos Estados-Nação. Isto se dá porque a Geopolítica clássica é fundamentalmente estatizada (BECKER, 2005), feita pelos Estados e para os Estados (VESENTINI, 2003), cujo objetivo principal consistia em substanciar estratégias de expansão de territórios e impérios e fundamentar discursos ideológicos dos Estados. Conforme afirma Adorno (1997)

\begin{abstract}
A geopolítica desempenhou papéis de destaque em vários Estados, principalmente aqueles envolvidos com interesses expansionistas ou imperialistas, ganhando maior expressão em cenários de guerra ou, quando não, em políticas territoriais regidas por governos essencialmente militares. Tradicionalmente assim conhecidos e utilizados, os sucessivos estudos geopolíticos se detiveram na interpretação da própria ideologia utilizada pelos Estados para galgarem sua afirmação internacional.
\end{abstract}

Desde os tratados clássicos desses fundadores do pensamento geopolítico, muitos elementos extremamente relevantes foram evoluindo: as técnicas de combate foram aprimoradas, as formas de exploração de energia foram inovadas e tornaram-se mais eficientes e poderosas, o acesso rápido e difusão farta de informações e dados por boa parte dos países do mundo é uma realidade que se consolida ainda mais a cada dia. As distâncias parecem ter sido diminuídas com deslocamentos cada vez mais velozes, seguros e baratos, ao passo que as economias de grande parte das nações do globo parecem estar cada vez mais interdependentes, sobretudo devido à internacionalização dos mercados financeiros (BAUMANN, 1996; GONÇALVES, 1996; ZINI JR, 1996; KIDWELL, 1993).

Entretanto, apesar de todas essas evoluções, que acabaram por definir uma sucessão de novos cenários geopolíticos pelos últimos séculos, talvez a maior e mais importante de todas as mudanças não tenha sido simplesmente o avanço das tecnologias de guerra ou das redes de circulação de bens e informações, mas uma consequência disso, que é criação de um novo cenário sócio-político e cultural, propício ao fortalecimento das identidades locais e à ascensão e fortalecimento da importância de novos atores geopolíticos e suas territorialidades, que por sua vez tem participação direta e indireta cada vez mais contundente das questões que envolvem, dentre outras, a gestão do território e o reconhecimento das territorialidades dos grupos historicamente social ou politicamente reprimidos pela 
ação ou omissão do Estado.

Se referindo à geopolítica da região amazônica no início do século $\mathrm{XX}$, Becker (2005) trata do paulatino fortalecimento do que denomina "coerção velada", representada pelas pressões de atores não-estatais para interferir nas ações do Estado sobre o planejamento e gestão de seus territórios, além de identificar dois "movimentos internacionais": o primeiro no nível do sistema financeiro, da informação, do domínio do poder efetivamente das potências; e outro relacionado ao que denominou internacionalismo dos movimentos sociais.

Vesentini (2003), ao tratar das novas geopolíticas surgidas na era da globalização e do enfraquecimento relativo dos Estados, aponta novos atores ou sujeitos geopolíticos que podem ser identificados:

(...) desde as civilizações ou grandes culturas até as ONG's, passando por empresas multi ou transnacionais, pelas organizações internacionais (ONU, OMC, FMI etc) e pelos "blocos" ou mercados regionais (União Europeia, Nafta, Mercosul etc).

Assim, em meados da segunda década dos anos 2.000, é cada vez mais sólida a superação do paradigma que delimita a geopolítica apenas sob um viés de disputa de territórios e poder entre estados-nação, onde o objetivo principal seria o reposicionamento de fronteiras políticas e alargamento das fronteiras econômicas com vistas à expansão territorial, defesa nacional e abertura e garantia de novos mercados para as corporações nacionais, ideia que se aproxima daquilo que Costa (1991) denominou "determinismo territorial". O que deve ser destacado, porém, é que, assim como nas últimas décadas novos países e continentes ganharam importância em seus contextos regionais - em alguns casos até mesmo num contexto mundial -, instituições não governamentais, corporações multinacionais e transnacionais, sindicatos e movimentos sociais organizados não podem mais ser minimizados a personagens coadjuvantes no campo da Geopolítica, pois elementos como identidade territorial e a luta pelas territorialidades e direitos étnicos passam a ser variáveis extremamente relevantes para a compreensão dos fenômenos geopolíticos, assim como os próprios conceitos de estado, nação, território e recursos foram relevantes para os tratados fundamentados no determinismo territorial. 
Interpretar o poder relacionado ao território significa relacioná-lo à capacidade dos atores de gerir, de implantar políticas econômicas e tecnológicas, com incidência estratégica no território, por parte tanto do Estado como dos múltiplos atores do/no poder, em alianças ou conflitos na gestão de políticas por capitais privados e por segmentos da sociedade civil que representam as diferentes regiões do território. (RUCKERT, 2004, p.149)

Trabalhando na esfera das escalas da análise geopolítica, Becker (2005) identifica um conceito chave para a nossa investigação, que é a "geopolítica abaixo da escala do Estado", admitindo que:

Todos os agentes sociais organizados, corporações, organizações religiosas, movimento sociais etc., têm suas próprias territorialidades, acima e abaixo da escala do Estado, suas próprias geopolíticas, e tendem a se articular, configurando uma situação mundial bastante complexa.

Dessa forma, fica evidente que o poder de pressão social, institucionalizado ou não, aumentou significativamente as possibilidades de atuação em prol da defesa de suas próprias territorialidades. Isto ocasiona, consequentemente, o aumento das tensões e conflitos entre os atores geopolíticos "abaixo da escala do estado" pelo atendimento de suas demandas estimuladas, sobretudo, pela consolidação de um processo de democratização das instituições, da política e da própria sociedade que o Brasil vem experimentando desde a Constituição de 1988.

\section{3 - O Reconhecimento das Territorialidades Étnicas: o papel constitucional do Estado Soberano}

Nesse contexto, em que novos cenários e desafios são impostos, em que demandas reprimidas por séculos ganham um novo espaço na agenda social e que 
um novo papel do Estado é demandado pela sociedade, se torna essencial que a abordagem geopolítica assuma como objeto de análise as questões étnicoterritoriais, sobretudo naquilo que se refere à garantia dos diretos à regularização das terras das comunidades tradicionais, tais como as quilombolas.

Reforço a fala de Adorno (1997), quando determina que a abordagem central dos estudos geopolíticos migrará da atenção ao promulgado Estado Territorial Orgânico aos movimentos políticos de classe e suas formas de manifestação pelo poder estatal', pois a geopolítica tradicional apresenta-se incapaz de traduzir o ato das políticas territoriais e a lógica das territorializações das relações sócio econômicas.

Para Pedrazza (2010, p. 16. Tradução nossa), a geopolítica representa o duplo desafio de trabalhar, por um lado, no nível teórico-metodológico e, por outro, num nível empírico através dos estudos de caso. Destaca ainda que:

\begin{abstract}
A criação de uma teoria implica na observação da realidade, sua evolução e detectar variáveis mais significativas, incluindo o motor que direciona a configuração dessa realidade. (...) A teoria é resultado de um processo de abstração a partir de variáveis significativas, selecionadas de uma realidade que conduz a um nível explicativo, e se realiza desde uma perspectiva: um lugar a partir do qual se situa o teórico para observar essa realidade. A esta perspectiva o lugar do qual observamos a realidade se denomina cosmovisão: uma ideia da organização do mundo que cria o marco ou paradigma para o resto das ideias e que inspira teorias e modelos em todos os níveis. Mostra o desenho universal da realidade e sua essência e se aplica a todos os campos: a política, a economia, a religião, a moral ou a filosofia. (PEDRAZZA, 2010, p. 16. Tradução nossa)
\end{abstract}

A abordagem da Geografia Política a respeito das relações entre Estado, Sociedade e Território admite várias perspectivas de análise. No âmbito das políticas públicas territoriais, tais como a regularização de territórios étnicos, destacamos inicialmente o papel do Estado enquanto ente territorial soberano. Esteves (2006, p.15), ao tratar desse Estado territorial moderno, destaca que a soberania nasceu sob o signo da construção de mecanismos de controle sobre indivíduos, grupos sociais e territórios, em um ambiente de profunda instabilidade e desordem. 
(...) cabe lembrar que a emergência do estado territorial soberano é em geral atribuída aos tratados de Vesfália de 1648, que puseram fim à Guerra dos Trinta Anos. Assinalaram estes, em primeiro lugar, a progressiva tentativa de imposição de limites à interferência da igreja sobre os nascentes governos seculares europeus; em segundo lugar, a autonomia em face dos demais Estados, tomados como juridicamente iguais e, finalmente, em terceiro lugar, a prerrogativa de manutenção da ordem no interior de suas fronteiras, bem como o controle sobre os recursos materiais e humanos necessários ao exercício do poder soberano. (ESTEVES, 2006, p.15)

Bastos Jr. (2014, p. 181-2), ao tratar da identificação do conjunto de elementos constitutivos do modelo de estado territorial soberano, apresenta uma matriz operativa a partir da qual, afirma, se estrutura a forma da política na modernidade:

(...) o modelo aqui identificado de "estado territorial soberano" será tratado como princípio organizativo e será decomposto em quatro dimensões distintas (autoridade, princípio organizativo, fundamento de legitimidade e critério para construção de identidades) que servirão de fio condutor para a compreensão das transformações experimentadas no processo de consolidação desse modelo de organização da comunidade política e dos seus influxos no desenvolvimento do conceito de soberania.

O instituto da territorialidade, compreendido por Bastos Jr (2014) no âmbito da construção das identidades que legitimam o estado a partir de sua própria soberania e, portanto, também deve ser considerado sob a perspectiva do reconhecimento de outras identidades territoriais e, portanto, outras territorialidades.

Sua ideia motriz (construção de identidades) decorre do reconhecimento de que qualquer grupamento pressupõe a fixação de vínculos de identidade entre seus membros que os distinguem daqueles que the são estranhos (do seu outro). No estado territorial soberano, é o atributo da cidadania que irá diferenciar o nacional do estrangeiro e que irá vincular aquele ao estado nacional, reconhecendo-Ihe direitos e imputando-lhe responsabilidades. A relação de pertencimento do indivíduo ao estado nacional tradicionalmente serve como o ponto de partida para a compreensão 
de cidadania. Ademais, foi justamente com base neste elo formal entre Estado e cidadão que foi possível forjar a concepção moderna de Nação como "comunidade política de destino". Trata-se de uma construção artificial que, fixada com base na demarcação de um elemento contingente (a fronteira), pretende uma espécie de homogeneização interna mediante o cultivo do passado (mitos sobre as origens do povo) e a promoção de elementos compartilhados (língua, etnia e religião).

Bastos Jr. (2014) destaca ainda que o estado territorial é, por obvio, um estado com fronteiras físicas e com um senso bem resolvido das relações dentro/fora e nós/eles. É justamente neste ponto, na consideração das relações estabelecidas nas fronteiras territoriais e da acomodação das diversas territorialidades envolvidas no processo de apropriação, organização e reordenamento do território (e de territórios) que se dá o fenômeno geopolítico que mais nos interessa no âmbito desta discussão: qual o alcance da soberania (poder territorial) do Estado frente a imperiosa função de garantir que as territorialidades "abaixo da escala do estado" (BECKER, 2005) não fragmentem a territorialidade nacional, que é um dos pilares que sustenta o próprio Estado? À nossa perspectiva, esse limite se dá, especialmente no âmbito das políticas públicas territoriais, nos termos definidos pela Constituição.

No caso específico da regularização de territórios quilombolas, compreendemos esses limites sobre dois fundamentos básicos, distintos entre si, porém complementares em sua função. O primeiro trata da garantia constitucional da igualdade e a justiça como valores supremos, explícitos ainda no preâmbulo do texto constitucional. Nesse sentido, cabe ao estado garantir que as territorialidades étnicas sejam reconhecidas e respeitadas em suas particularidades e demandas específicas. O segundo trata da materialização da vontade constitucional, que obriga a ele, o Estado, a executar ações que visem a formalização desses direitos étnicos territoriais e fundamentais, ou seja, que crie e efetive condições para a segurança fundiária, jurídica e territorial a esses povos tradicionais, a partir da outorga do título de propriedade das terras que ocupam. O poder territorial contido na soberania do Estado em prol da vontade constitucional é, em nosso entendimento, a questão chave para a conjugação do interesse das diversas demandas territoriais frente àquelas apresentadas pelas comunidades étnicas e suas territorialidades 
específicas, sobretudo, quando equaliza as condições de disputa pela apropriação territorial.

É nesse sentido que toma relevância a proposição de Raffestin (1993, p.143), em que aponta que "o território se forma a partir do espaço, é o resultado de uma ação conduzida por um ator sintagmático (ator que realiza um programa) em qualquer nível". Esclarece ainda que "ao apropriar de um espaço concreta ou abstratamente (por exemplo, pela representação), o ator territorializa o espaço". Estas reflexões são importantes à medida que trazem à baila a possibilidade de se pensar o território como algo criado e formatado a partir da ação humana em prol de suas próprias motivações, sejam elas de caráter produtivo, cultural, social, político etc.. Silva (2012), orienta que a contribuição de Raffestin (1993) oferece a compreensão de que:

(...) a ideia de poder passou a ser assumida em suas diversas origens e manifestações, mas sempre focando sua projeção no espaço. O próprio uso e transformação dos recursos naturais se configuram como instrumentos de poder, o que ressalta a consideração da natureza como elemento presente no território. O autor também buscou diferenciar conceitualmente espaço e território. Para ele, o espaço está relacionado ao patrimônio natural existente em uma região definida, enquanto o território abrange a apropriação o espaço pela ação social de diferentes atores. Assim, o território incorpora o jogo de poder entre os atores de um determinado espaço. (SILVA, 2012, p. 151-2)

Nesse contexto o papel do próprio Estado enquanto regulador e vetor de estruturação de reestruturação do espaço (MELLO, 2003) está no fundamento para a compreensão dos processos de construção das políticas públicas territoriais atualmente vigentes no Brasil. No contexto da análise Cartografia Quilombola no Brasil, Dos Anjos (2006, p. 339) afirma que:

O território é, na sua essência, um fato físico, político, social, categorizável, possível de dimensionamento, onde geralmente 0 Estado está presente e onde estão gravadas as referências culturais e simbólicas da população. Dessa forma, o território étnico seria o espaço construído, materializado a partir das referências de identidade e pertencimento territorial, onde geralmente a sua população tem um traço de origem comum. As demandas históricas e os conflitos com o sistema dominante têm imprimido a esse tipo de 
estrutura espacial exigências de organização e a instituição de uma autoafirmação política, social, econômica e territorial.

Nesse sentido, o território se forma a partir da construção de uma ideia de pertencimento físico, psicológico ou identitário de um ator ou grupo a um fragmento do espaço geográfico, em resposta às motivações e intencionalidades de seus pares. Assim, a concepção de território está basicamente ligada às relações de poder existentes entre os mais diversos atores políticos, admitindo, portanto, que o território concreto, imaginário ou idealizado carrega em si as marcas de poder de um ator sobre seus pares e deste sobre outros grupos.

O território, nessa perspectiva, um espaço onde se projetou um trabalho, seja energia e informação, e que, por consequência, revela relações marcadas pelo poder. O espaço é a "prisão original", o território é a prisão que os homens constroem para si. (RAFFESTIN, 1993, p.143-144).

Ao tratar da formação dos chamados sistemas territoriais, Raffestin (1993) reconhece que "um sistema de ações ou de comportamentos se traduz por uma produção territorial que faz intervir tessitura, nó e rede". Estabelece ainda que:

Esses sistemas de tessituras, de nós e de redes organizadas hierarquicamente permitem assegurar o controle sobre aquilo que pode ser distribuído, alocado e/ou possuído. Permitem ainda impor e manter uma ou várias ordens. Enfim, permitem realizar a integração e a coesão dos territórios. Esses sistemas constituem invólucro no qual se originam as relações de poder. (RAFFESTIN, 1993)

Discutir o território e sua apropriação pelos mais diversos grupos sociais e políticos nos termos estabelecidos por Ruckert (2010) e Raffestin (1993) nos obriga a considerar como fundamentais as relações de poder entre os atores políticos e 
sociais e suas respectivas formas de apropriação do território. Significa tratar, portanto, da territorialidade. Para Raffestin (1993), a territorialidade é uma relação entre o homem ou grupos sociais e o território, bem como as consequências do produto dessa relação para com os outros homens e grupos.

\begin{abstract}
A territorialidade aparece então como constituída de relações mediatizadas, simétricas ou dissimétricas com a exterioridade. É urgente abandonar as analogias animais para tratar da territorialidade humana. A territorialidade se inscreve no quadro da produção, da troca e do consumo das coisas. Conceber a territorialidade como uma simples ligação com o espaço seria fazer renascer um determinismo sem interesse. É sempre uma relação, mesmo que diferenciada, com os outros atores. (...) Cada sistema territorial segrega sua própria territorialidade, que os indivíduos e as sociedades vivem. A territorialidade se manifesta em todas as escalas espaciais e sociais; ela é consubstancial a todas as relações e seria possível dizer que, de certa forma, é a "face vivida" da "face agida" do poder. (RAFFESTIN, 1993, p.161-162)
\end{abstract}

No contexto da importância da consideração das relações de poder entre os indivíduos e grupos sociais para o entendimento das noções de território e dos processos de territorialização, Haesbaert (2005, p.6.775) estabelece que:

(...) se o espaço social aparece de maneira difusa por toda a sociedade e pode, assim, ser trabalhado de forma genérica, o território e os processos de des-territorialização devem ser distinguidos através dos sujeitos que efetivamente exercem poder, que de fato controlam esse(s) espaço(s) e, consequentemente, os processos sociais que o(s) compõe $(\mathrm{m})$. Assim, o ponto crucial a ser enfatizado é aquele que se refere às relações sociais enquanto relações de poder - e como todas elas são, de algum modo, relações de poder, este se configura através de uma noção suficientemente ampla que compreende desde o "anti-poder" da violência até as formas mais sutis do poder simbólico. (Grifo nosso)

Haesbaert (2005, p.6.777) destaca ainda a importância de se reconhecer dois tipos ideais ou referências extremas para a investigação do território: o funcional e o simbólico. 
Enquanto "tipos ideais" eles nunca se manifestam em estado puro, ou seja, todo território "funcional" tem sempre alguma carga simbólica, por menos expressiva que ela seja, e todo território "simbólico" tem sempre algum caráter funcional, por mais reduzido que ele seja. Num esquema genérico dos extremos deste já aludido continuum entre funcionalidade e simbolismo (...).

As noções de território e territorialidade estão ligadas, portanto, ao fruto das relações de poder político e econômico entre os atores, sejam estes indivíduos ou grupos sociais.

\section{4 - Estado e Poder Territorial}

Ao tratar sobre o termo "poder" em sua teoria geral da Política, Bobbio (1987) identifica pelo menos três teorias fundamentais: a substancialista, a subjetivista e a relacional. Sobre a teoria substancialista, indica que "o poder é concebido como uma coisa que se possui e se usa como um outro bem qualquer", identificando em Hobbes uma típica interpretação dessa teoria, pois salienta que, nas palavras de Hobbes "o poder de um homem (...) consiste nos meios de que presentemente dispõe para obter qualquer visível bem futuro".

Que estes meios sejam dotes naturais, como a força e a inteligência, ou adquiridos, como a riqueza, não altera o significado precípuo do poder entendido como qualquer coisa que serve para alcançar aquilo que é o objeto do próprio desejo. (BOBBIO, 1987, p.77)

Bobbio (1987), ao tratar sobre a teoria substancialista do poder, evoca ainda as palavras de Bertrand Russel, sintetizando a categorização das três formas de poder identificadas enquanto:

(...) poder físico e constritivo, que tem a sua expressão concreta mais visível no poder militar; poder psicológico à base de ameaças de punição ou de promessas de recompensas, em que consiste principalmente o domínio econômico; poder mental, que se exerce através da persuasão e da dissuasão e tem a sua forma elementar, 
presente em todas as sociedades, na educação. (BOBBIO, 1987, p.77)

Ao caracterizar a teoria subjetivista do poder, Bobbio (1987) recupera a interpretação de Locke (1694), a qual sustenta a tese que:

(...) por "poder" entende não a coisa que serve para alcançar o objetivo mas a capacidade do sujeito de obter certos efeitos, donde se diz que "o fogo tem o poder de fundir os metais" do mesmo modo que o soberano tem o poder de fazer as leis e, fazendo as leis, de influir sobre a conduta de seus súditos. Este modo de entender o poder é o adotado pelos juristas para definir o direito subjetivo: que um sujeito tenha um direito subjetivo significa que o ordenamento jurídico the atribuiu o poder de obter certos efeitos. (BOBBIO, 1987, p.77-78)

Na perspectiva de Bobbio (1987), porém, a teoria relacional é aquela mais aceita pelo discurso político contemporâneo, "que remete ao conceito relacional do poder e estabelece que por „poder' se deve entender uma relação entre dois sujeitos, dos quais o primeiro obtém do segundo um comportamento que, em caso contrário, não ocorreria". Outra definição do poder relacional destacada por Bobbio (1987) é aquela proposta por Robert Dahl, onde o poder é uma categorização dentro de um conceito mais amplo, a influência.

Ancorado na perspectiva do poder relacional, o poder territorial, no sentido empregado em nossa proposta teórica, responde pela capacidade de determinado agente/ator, público ou privado, individual ou coletivo, fazer valer o seu interesse sobre o território e seus recursos, sejam eles materiais ou imateriais, potenciais ou latentes, tangíveis ou intangíveis, considerando a motivação e intencionalidade de cada um dos atores envolvidos. Nesse contexto, admitimos que os objetivos ou demandas dos atores podem ser de ordem estratégica (proteção ambiental, defesa militar, planejamento territorial, circulação etc) ou comum (exploração dos recursos naturais, estabelecimento de núcleos de habitação planejados ou não, áreas agricultáveis etc).

Assim, reconhecemos em nossa posição uma estreita ligação com o estabelecido por Nye Jr. (2012), que discute o significado do chamado "poder relacional". Tal qual Nye Jr., observamos, de fato, que estabelecer conceitos 
geopolíticos que atendam às expectativas - e sobretudo às perspectivas, de um sem número de atores estatais, militares, econômicos, políticos, bem como de pensadores da academia e de ativistas e voluntários de organismos nãogovernamentais é tarefa bastante complexa e realmente complicada. Nesse ínterim, após destacar várias passagens que relatam diferentes concepções de poder, chama-nos a atenção a conclusão de Nye Jr., onde afirma que:

(...) no fim, é com os resultados, não com os recursos, que devemos nos importar. Precisamos prestar mais atenção aos contextos e às estratégias. As estratégias de conversão de poder passam a ser uma variável fundamental que não recebe atenção suficiente.

Nesse contexto de análise, podemos concluir que o poder sobre o território emana das relações entre os atores sócio-políticos. Na perspectiva de atendimento de suas necessidades e interesses sobre o território e seus recursos, materiais ou imateriais, estabelecem um sistema de associações, impasses, tensões, conflitos e lutas na disputa pela ocupação, uso, posse, domínio, gestão e/ou soberania sobre o território.

É a partir dessa premissa básica que fundamentamos nosso entendimento a respeito do processo de apropriação do poder sobre o território, ou poder territorial e, mais adiante, nos propomos a lançar algumas bases gerais para o entendimento desse processo nas políticas públicas territoriais e os direitos étnicos, especialmente nas ações de titulação das terras quilombolas no Brasil.

A compreensão da lógica de apropriação do poder territorial desempenhada pelos mais diversos grupos de interesse, dentre eles os povos tradicionais quilombolas, classificadas por Haesbaert (2014) como "grupos subalternos", são essenciais para a correta interpretação da intencionalidade e trunfos que convergem para determinada política e do modus operandis dos atores sócio-políticos envolvidos no processo. As ações de intervenção territorial, por sua vez, são implementadas tendo em vista a necessidade da gestão do território e, por consequência, de um sistema que possibilite o ordenamento da estrutura fundiária do país, do zoneamento produtivo, das práticas de conservação e proteção 
ambiental etc., pensadas nas mais diversas escalas de análise e planejamento (RUCKERT, 2010).

\begin{abstract}
A importância da análise dos usos do território circunstancia-se tanto às concepções clássicas da geografia política - o poder unidimensional do Estado - quanto aos enfoques contemporâneos sobre a multidimensionalidade do poder, os múltiplos territórios e as múltiplas territorialidades. Assim, a multidimensionalidade do poder adotada para as políticas territoriais é conceituada no sentido de que diferentes atores produzem o espaço, (re)estruturam o território através da prática de poderes / políticas / programas estratégicos, gestão territorial, enfim. A gestão de ações / programas que contém caráter (re)estruturante e/ou com capacidade de alavancagem de desenvolvimento endógeno imprime, assim, novos usos do território. (RUCKERT, 2010, p. 20)
\end{abstract}

Abordando a importância da dimensão territorial no contexto das políticas públicas, Mello-Théry (2011) entende o território como um elemento norteador, admitindo-o, portanto, com um papel fundamental no planejamento e execução das atividades e programas a serem implementados. Essa compreensão reforça o que afirma Correa (1996), quando estabelece que a gestão do território implica o controle da organização social, o que denota a importância da consideração das políticas públicas territoriais como um instrumento geopolítico de extrema relevância.

Partindo da análise e avaliação dos processos de tomada de decisões que envolvem as ações instituídas pelo estado, governos e sociedade civil, no que se refere à titulação das terras quilombolas, pode-se concluir que as políticas públicas territoriais se definem pelo conjunto de instrumentos adotados pelos governos, seja num âmbito federal, estadual ou municipal em prol do esforço de materialização dos anseios ou demandas de um determinado grupo de interesse ou pressão, partidos políticos, movimentos sociais etc., que podem se reunir a partir de motivações e intencionalidades comuns, pautadas em aspirações políticas, sociais, culturais, econômicas etc.

As políticas públicas, dessa forma, são concebidas como fruto de uma relação dos conflitos entre os interesses dos governos e demais atores a ele associado por um lado, e o Estado e seus princípios constitucionais e demais grupos de interesse não diretamente associados aos governos, de outro. Nesse sentido, entende-se 
estas políticas públicas como uma tentativa de uma busca de afirmação dos direitos, demandas e/ou conveniências de determinados grupos ligados ao Governo (quem governa e para quem se governa) frente à negação/omissão dos direitos, demandas e/ou conveniências de outros grupos (quem não governa e para quem não se governa), seja de forma autoritária, velada, discriminatória, omitiva, inconsciente etc.

Uma das bases teóricas que sustenta essa concepção baseia-se no fato de que os governos geralmente trabalham suas proposições a partir de uma motivação externa, ou seja, influenciado pela pressão, lobby, acordos e/ou associações que atendem a demandas específicas de um determinado grupo social ou político. Para materializar essas demandas, o governo combaterá, comprometerá ou pelo menos se omitirá a respeito do direito dos demais grupos sócio-políticos. É importante notar que, mesmo que a política pública governamental não afete diretamente os interesses dos demais grupos, essa afetação se dará de forma indireta, à medida que os recursos orçamentários, financeiros, políticos, humanos e de infraestrutura direcionado para as demandas do grupo A poderiam estar sendo direcionados às demandas dos grupos B, C ou D. Essa definição se alinha em muitos aspectos ao modelo de formulação e análise de políticas pública conhecido como "arenas sociais". Souza (2006) entende que esse modelo:

(...) vê a política pública como uma iniciativa dos chamados empreendedores políticos ou de políticas públicas. Isto porque, para que uma determinada circunstância ou evento se transforme em um problema, é preciso que as pessoas se convençam de que algo precisa ser feito. É quando os policy makers do governo passam a prestar atenção em algumas questões e a ignorar outras (...) Esses empreendedores constituem a policy community, comunidade de especialistas, pessoas que estão dispostas a investir recursos variados esperando um retorno futuro, dado por uma política pública que favoreça suas demandas. Eles são cruciais para a sobrevivência e o sucesso de uma ideia e para colocar o problema na agenda pública. Esses empreendedores podem constituir, e em geral constituem redes sociais. Redes envolvem contatos, vínculos e conexões que relacionam os agentes entre si e não se reduzem às propriedades dos agentes individuais. As instituições, a estrutura social e as características de indivíduos e grupos são cristalizações dos movimentos, trocas e "encontros" entre as entidades nas múltiplas e intercambiantes redes que se ligam ou que se superpõem. $O$ foco está no conjunto de relações, vínculos e trocas entre entidades e indivíduos e não, nas suas características. Este método e referencial teórico partem do estudo de situações concretas para investigar a integração entre as estruturas presentes e as ações, estratégias, constrangimentos, identidades e valores. As 
redes constrangem as ações e as estratégias, mas também as constroem e reconstroem continuamente. A força deste modelo está na possibilidade de investigação dos padrões das relações entre indivíduos e grupos (SOUZA, 2006, p. 32-33).

Em termos gerais, tratar das ações de titulação das terras quilombolas significa necessariamente abordar, como ponto de partida, as relações de disputa por um bem finito e estratégico, que é o território.

Ainda que lutas sociais de transformação, obviamente, não se resumam à busca de delimitações zonais, estas têm adquirido um grau de centralidade, especialmente em movimentos como os dos chamados povos tradicionais.(...) A "lógica de dominante zonal" de construção do espaço precisa então, ser rediscutida, especialmente se lembrarmos que o próprio Estado contemporâneo, mesmo reconfigurado, principalmente no caso de alguns países latino-americanos, continua pautando suas políticas territoriais e/ou regionais (conceitos muitas vezes usados como sinônimos) em termos de espaços zonais, de superfícies ou áreas bem delimitadas. (HAESBAERT, 2014, p.03-05)

Em contrapartida, traz nos componentes produtivo e sociocultural uma faceta que não pode ser nunca desprezada, que é a territorialidade. Essas relações de disputa, por vezes enquadradas como verdadeiras questões geopolíticas, envolvem diversos atores, como o poder público, as forças armadas, a sociedade civil, as pequenas, médias e grandes corporações empresariais, os movimentos sociais etc. 
Tomemos como exemplo agora um caso que está mais ligado ao mundo agrário, rural - 0 dos chamados povos tradicionais. Conjugam-se aí dinâmicas de contenção com (contra)lógicas subalternas de dominância zonal. Aqui, é importante lembrar que essas zonas às quais são relegados muitos grupos "tradicionais", que à primeira vista parecem ser conquistas desses grupos, são também e sobretudo resquícios, espécie de resíduo ou sobra após a devastação brutal que o colonialismo promoveu em território americano. Nesse sentido, também podem ser vistas como formas de contenção territorial, na medida em que contêm a expansão desses grupos e tentam confiná-los em áreas muitas vezes periféricas e/ou extremamente precarizadas. (HAESBAERT, 2014, p.11)

Haesbaert (2014, p. 11-12) ainda chama a atenção para uma ambiguidade que caracteriza a luta dessas comunidades, uma vez que entende que, após a conquista de um território residual, as comunidades passam a ser relegadas a situações de precariedade e isolamento:

A luta pela definição de seus territórios envolve ainda uma reinvenção identitária, implicada na própria legislação que, pelo menos em determinado momento, força o grupo a uma definição clara entre eles e "os outros", definição a partir da qual será traçada sua delimitação territorial. Assumidas ou atribuídas, essas identidades estão imersas num jogo político de estabelecimento de uma área ou zona bem definida. Numa sociedade em que tanto se fala em hibridismo e trocas culturais, a definição clara de territórios por uma base étnica pode parecer paradoxal. Mas o mais importante é perceber que esses territórios dos povos tradicionais são também uma conquista desses grupos e que, ainda que indiquem certa separação étnico-cultural - mas que pode representar a única condição que resta para sua sobrevivência enquanto culturas distintas -, implicam em outra conquista que é a subversão da lógica privatista da terra e a instituição do seu usufruto coletivo. Pelo lado socioeconômico, trata-se de espaços relativamente vastos (principalmente na região Amazônica) que estão vedados à apropriação privada e que, pelo menos em tese, são de usufruto comunitário, exclusivo desses grupos sociais. (Grifo nosso)

Para a análise das ações de reconhecimento e titulação das terras quilombolas, é importante destacar a necessidade de estabelecer algumas delimitações a respeito das forças políticas, sociais e econômicas que cooperam ou obstaculizam esses esforços. 
A primeira dessas considerações consiste na identificação das possibilidades e dos limites de atuação de duas forças que dividem as prerrogativas constitucionais do poder público: o estado e o governo.

Bobbio et al (1998) traz uma definição contemporânea do termo governo, identificando duas acepções básicas. Na primeira, o Governo se define como:

(...) o conjunto de pessoas que exercem o poder político e que determinam a orientação política de uma determinada sociedade. É preciso, porém, acrescentar que o poder de Governo, sendo habitualmente institucionalizado, sobretudo na sociedade moderna, está normalmente associado à noção de Estado. (BOBBIO et al, 1998, p 555).

A segunda acepção, mais ampla, define o termo para além de um grupo de pessoas que detém o poder de governo (governantes), mas também o complexo de órgãos que institucionalmente têm o exercício do poder. Nesse sentido, o governo constitui um aspecto do Estado (BOBBIO et al, 1998, p. 555). O poder executivo é composto pela administração pública, responsável pela gestão da burocracia estatal, e pelo Governo, que é formado pelo conjunto de órgãos decisórios. Rocha (2009, p.142) chama a atenção para as ações concorrentes entre o estado e os governos, apontando que:

O governo possui a discricionariedade, que é a liberdade de ação e de escolha nos limites da legalidade, mas o Estado possui princípios que limitam a opção ideológica dos governos. As opções ideológicas dos governos correspondem à fonte soberana do poder, que nas democracias é expressa pelo voto popular, mas é definida por um conjunto complexo de forças sociais que compõe uma elite efetivamente poderosa.

Sobre a prerrogativa, que é a discricionariedade do poder executivo, o clássico texto de Locke (2006) estabelece que se trata da possibilidade do governo preencher as lacunas deixadas pelo poder legislativo no emaranhado das leis, constituindo-se assim um verdadeiro poder. 
Há muitas coisas em que a lei não tem meios de desempenhar um papel útil; é preciso então necessariamente deixá-las a cargo do bom-senso daquele que detêm nas mãos o poder executivo, para que ele as regulamente segundo o exigirem o bem público e suas vantagens. Mais que isso, convém às vezes que as próprias leis se retraiam diante do poder executivo, ou antes, diante da lei fundamental da natureza e do governo, ou seja, que tanto quanto possível todos os membros da sociedade devem ser preservados. (LOCKE, 2006, p.79)

A partir da consideração de um contexto constitucional de separação dos poderes e dos freios e contrapesos entre eles e da discricionariedade ou prerrogativa do governo na condução das ações de titulação das terras quilombolas, identificamos o governo como um ator político à parte do Estado: um não pode ser completamente integrado ao outro, pois apresentam motivações, estruturas, intencionalidades e trunfos diferentes entre si. Em outras palavras, admitimos que o Governo possa ser entendido como uma personificação do poder central eleito pelo povo a partir do voto para cumprimento de mandato por um período determinado, ou seja, são os representantes do povo ocupando ferramentas do estado, dotados do poder discricionário, responsáveis pela gestão dos recursos orçamentários e materiais da Administração Pública e do controle da agenda do PoderExecutivo.

No caso brasileiro, que é uma república presidencialista pluripartidária, esses titulares encontram-se liderados pelo Presidente da República, que é o Chefe de Estado e do Poder Executivo, sendo sustentado politicamente pelo partido político e pela eventual coligação partidária a que pertence. De acordo com o ordenamento das variáveis políticas conjunturais, esse suporte poderá evoluir para uma coalizão de governo e, a partir daí, cooperar para o sucesso das aspirações do executivo no seio do poder legislativo. Em outras palavras, a ideia de Governo pode ser sintetizada na identificação de "quem governa" e "com quem se governa".

Dentro da consideração de um cenário político mais amplo, essa perspectiva abre caminho para a correspondente e relevante identificação do outro lado da dicotomia: "quem não governa" e "para quem não se governa". Em linhas gerais, o grupo "quem não governa" é aqui identificado como as forças de oposição no seio do poder legislativo, o poder judiciário e a maior parcela do executivo, entendida como a máquina pública formada pela administração direta excetuando-se, no 
entanto, os cargos de confiança indicados discricionariamente pelo Governo. $\mathrm{O}$ grupo dos "para quem não se governa" é constituído pelas forças da sociedade que mantém suas bases filosóficas, ideológicas e/ou conveniências econômicas e/ou políticas contrapostas às daqueles grupos de sustentação do governo eleito.

Dado esse cenário de disputa pelo poder político em várias frentes de ação, é possível assumir que o estado teria instrumentos para frear a atuação do governo a partir de instrumentos constitucionalmente previstos. Tais ferramentas podem ser encaradas como artifícios administrativos e jurídicos contra a usurpação do poder estatal pelo governo visando o atendimento de interesses restritos aos grupos que 0 sustenta ou financia. Por seu lado, o governo usa a prerrogativa de liberdade de tomada de decisões deixadas pelas lacunas das leis - discricionariedade, que são balizadas a partir de critérios ideológicos ou de conveniência econômica e/ou política compartilhados pelos grupos sociais que estão em sua base: "quem governa" e "com quem governa".

Nesse contexto, é de grande relevância o amadurecimento do debate que delimita as relações entre estado e governo. Para Rocha (2009, p.141),

\begin{abstract}
A diferença entre Estado e governo é atualmente mais acentuada com a personalização jurídica do Estado, porque o Estado como pessoa tem vontade própria, distinta da vontade individual do governante. No Estado Democrático e de Direito há a perspectiva de reduzir a participação do governo ao máximo possível. Fazem parte deste Estado e não fazem parte do seu governo a Constituição, o conjunto de servidores públicos estáveis, o patrimônio público, a máquina burocrática pública, as forças públicas, etc. Isto porque a sociedade precisa que estas instituições sejam estáveis e impessoais, que não estejam sujeitas às mudanças de governo no processo eleitoral e que sejam republicanas - pertencente ao conjunto da sociedade e não aos interesses de quem está no poder. Isto é uma peculiaridade da democracia constitucional, nos regimes autoritários a ausência de limites aos governos os levam absorver ao máximo o Estado. O princípio republicano de responsabilidade política dos governos está presente nas constituições modernas das democracias e das monarquias, como limite ao poder e como identificação da coisa pública distinta do governo.
\end{abstract}

Dadas essas definições, é possível identificar como uma das funções do estado trabalhar para que o governo não se apodere da (infra)estrutura e das 
prerrogativas estatais de forma a reduzir os recursos do estado a meras ferramentas de um projeto particular direcionado aos interesses "para quem se governa", como por exemplo a implementação de intervenções no território em prejuízo do interesse comum da sociedade. Nesse contexto, emerge a necessidade de consideração da sociedade civil nesse processo.

Nas democracias constitucionais contemporâneas, sociedade civil e estado constituem uma dicotomia onde a delimitação e significado de um depende necessariamente da observação da extensão e significado do outro. Nesse sentido, Bobbio (1987) estabelece que:

(...) negativamente, por sociedade civil, entende-se a esfera das relações sociais não reguladas pelo Estado, entendido restritivamente e quase sempre também polemicamente como 0 conjunto dos aparatos que num sistema social organizado exercem o poder coativo. (BOBBIO, 1987, p.33).

Porém, até a ascensão do estado burguês, estado e sociedade se confundiam numa mesma instituição, sendo a segunda uma categorização interna da primeira (BOBBIO, 1987). Contudo, com a nova idealização das funções e limites do Estado, restringindo-o, ganham força novos fundamentos ideológicos que cooperam para uma nova configuração do jogo do poder. Dentre essas novas bases ideológicas, são destacadas:

(...) a afirmação de direitos naturais que pertencem ao indivíduo e aos grupos sociais independentemente do Estado e que como tais limitam e restringem a esfera do poder político; a descoberta de uma esfera de relações interindividuais, como são as relações econômicas, para cuja regulamentação não se faz necessária a existência de um poder coativo, posto que se auto-regulam. (BOBBIO, 1987, p.33-34)

Com a ascensão dos estados democráticos e constitucionais, a sociedade civil adquire um novo status de representatividade dentro do jogo político do poder, constituindo-se como um dos principais atores políticos. A partir dessa concepção do termo, que se alia à concepção defendida no tópico anterior, que trata da identificação dos atores "para quem se governa" ou "para quem não se governa", 
parte-se para a consideração das várias subdivisões da sociedade civil enquanto instituição formada por diversos atores não-estatais imbuídos do poder de pressão e coação junto ao governo e ao poder estatal que lhe é atribuído. Nesse sentido, são destacados os grupos de interesse, os grupos de pressão, os lobistas e os partidos.

Os grupos de interesse podem ser definidos como associações de indivíduos ou instituições que se unem pela defesa de uma causa em comum, que podem estar relacionadas à melhoria da qualidade de vida de determinadas populações a partir da garantia de direitos constitucionalmente previstos, pela revisão da postura do poder central eleito frente a uma demanda específica etc.. Segundo Bobbio (1998) sua definição mais explícita se acha em Truman (1951), para o qual grupo de interesse é:

(...) qualquer grupo que, à base de um ou vários comportamentos de participação, leva adiante certas reivindicações em relação a outros grupos sociais, com o fim de instaurar, manter ou ampliar formas de comportamento que são inerentes às atitudes condivididas.

Assim, os grupos de interesse podem ser entendidos mais como instâncias de posicionamento ou alinhamento frente a determinado tema ou questão sócio-política ou cultural do que um grupo de ação política, como é o caso, por exemplo, dos grupos de pressão.

Os grupos de pressão são definidos por Bobbio (1998) como um conjunto de indivíduos com motivações comuns que tentam influenciar as decisões do poder político, mas não obter o poder político para si. Seus trunfos são as sanções positivas (prêmios) ou negativas (punições) ou mesmo pela simples ameaça de sanções que estão ao seu alcance, "seja a fim de mudar a distribuição prevalente de bens, serviços, honras e oportunidades, seja a fim de conservá-la frente às ameaças de intervenção de outros grupos ou do próprio poder político".

Finalmente podemos concluir que são grupos de pressão aqueles grupos organizados que, embora tendo em mira influenciar sobre a distribuição dos recursos numa sociedade, seja para mantê-la sem alteração, seja para introduzir mudanças em seu favor, não participam diretamente no processo eleitoral e por isso mesmo não estão interessados em gerir in proprio o poder político, e sim em 
aproximar-se dele com facilidade e frequência e a influenciar as opções. (BOBBIO, 1998, p.564).

Ao fazer um paralelo entre a atuação dos grupos de pressão nos Estados Unidos e no Brasil, Rodrigues (2000, p. 07) aponta que:

O atual período democrático que desfrutamos tem sido eminentemente propício ao aparecimento de grupos da sociedade civil. A explosão de grupos que os Estados Unidos viu brotar em sua sociedade nos anos setenta encontra seu paralelo brasileiro no atual período democrático. Meio ambiente, transparência política, reforma agrária, idosos, mulher, fome, todos estes temas estimularam a formação de grupos de pressão no Brasil.

No que se refere à atuação dos grupos de pressão no sentido de influenciar a tomada de decisão do poder público na implementação de suas políticas, Rodrigues Vencidos esses trâmites salienta que:

No trabalho de persuadir legisladores e autoridades públicas encarregadas da formulação de políticas públicas, os grupos de pressão apresentam uma variedade de estratégias. Em primeiro lugar, sua atuação pode ocorrer dentro e fora do Congresso Nacional. Em segundo, pode almejar o processo legislativo ou a implementação das políticas. No primeiro caso, o trabalho pode ser dirigido a parlamentares individualmente, a bancadas especializadas ou a partidos políticos. Como, no Brasil, o Poder Executivo tem iniciativa de lei, os grupos também dirigem sua atenção para autoridades e funcionários ali lotados. Por fim, todo o processo pode ser pontuado por um forte trabalho de divulgação nos meios de comunicação de massa, visando, acima de tudo, influenciar a opinião pública.

Ainda sobre a sorte de atores que operam no seio da sociedade civil, os lobistas são caracterizados por Bobbio (1998) como o grupo de intermediários entre os grupos de pressão e o poder central eleito, integrantes do poder legislativo ou mesmo do judiciário. Destaca ainda que: 
Lobbying é, portanto e sobretudo, uma transmissão de mensagens do grupo de pressão aos decision-makers, por meio de representantes especializados (em alguns casos, como nos Estados Unidos, legalmente autorizados), que podem ou não fazer uso da ameaça de sanções. (BOBBIO, 1998, p563-564).

Os partidos também são peças fundamentais para o equilíbrio do jogo do poder político. Apresentam características muito semelhantes àquelas apresentadas pelos grupos de pressão, tais como "a função de transmissão do questionamento político, de mediação entre sociedade e Governo, de recrutamento político, de participação política e de integração social" (BOBBIO, 1998, p.565). Contudo, Bobbio (1998) identifica três características assumidas pelos partidos políticos que os diferenciam dos grupos de pressão, que são a função de competição eleitoral, a função de gestão direta do poder e talvez a função de expressão democrática.

$\underline{0}$ grande desafio, nesse momento, passa a ser a compreensão da intencionalidade do governo nas suas decisões discricionárias e do grau de aderência dessa intencionalidade com os impactos gerados por essas decisões.

Para exemplificar essa ideia, sugerimos a provocação: os atos discricionários tomados pelos sucessivos governos brasileiros desde a promulgação da Constituição de 1988, no âmbito das ações de titulação das terras quilombolas, promoveram condições efetivas para que se alcançasse a segurança fundiária das comunidades ou trouxeram consigo elementos que dificultaram esse processo?

Em nossa perspectiva, qualquer resposta a essa provocação não estaria completa caso não fossem consideradas todas as variáveis dessa equação: 1) a atuação do Estado enquanto guardião da constitucionalidade dos atos do Governo e do interesse público dessas ações; 2) dos limites da ação discricionária do Governo e da intencionalidade de suas decisões e controle da agenda pública; 3) das várias facetas assumidas pela sociedade civil quando da adesão ou distanciamento do projeto político-ideológico defendido pelo Governo.

Apreende-se que essas ações são frutos de um processo de conquista sóciopolítica que se originou do conjunto de mobilizações junto ao poder executivo, legislativo e da sociedade em geral. Porém, se analisada a partir dos instrumentos jurídico-administrativos que convergiram para a legislação vigente (Artigo 68 das ADCT, Decreto 4887 e da Instrução Normativa 57 do INCRA) e dos resultados que foram alcançados desde 1988, nos permitem concluir que algumas das 
características da ação direta (e indireta) do Governo não resultaram na conquista dos direitos das comunidades quilombolas à segurança fundiária, mas trabalharam, mesmo que involuntariamente, pela restrição da participação das comunidades na tomada de decisões estratégicas sobre o atendimento de suas demandas territoriais.

A despeito do fracasso das ações, o que será demonstrado com mais detalhes nos decorrer deste trabalho, observa-se a perpetuação de um discurso políticoideológico que muitas vezes assume uma visão partidarizada, que aprisiona esses grupos a uma perspectiva-possibilidade-promessa de titulação de suas terras que

nos parece atender muito mais aos objetivos dos grupos de pressão e partidos políticos ligados ao governo do que realmente aos interesses das comunidades quilombolas em ter suas terras regularizadas.

Nesse momento, tendo em vista a complexidade que envolve a questão das ações de titulação das terras quilombolas, passaremos à apresentação de uma proposta metodológica voltada à análise da efetivação desses direitos, que será a referência metodológica básica para o decorrer do trabalho aqui apresentado.

\section{5 - Titulação das terras quilombolas: parâmetros para a análise}

Os estudos referentes às políticas públicas no Brasil têm crescido em termos de quantidade e qualidade nas últimas décadas, e tornou-se objeto de estudos em diversas áreas da ciência (SOUZA, 2003; TREVISAN, van BELEN, 2008). Frey (2000) aponta que, além de muito recentes, a maioria desses estudos dão ênfase ou à análise das estruturas e instituições ou à caracterização dos processos de negociação das políticas setoriais específicas, abordando, sobretudo, os efeitos dos programas públicos de forma descritiva e com graus de complexidade analítica e critérios metodológicos bastante distintos.

Na perspectiva de Mello-Théry (2011), política pública é processo pelo qual os diversos grupos tomam decisões coletivas, as quais se convertem em uma política comum. Uma de suas características principais é que 
revestidas da autoridade soberana do poder público, cujas dimensões acontecem simultânea e permanentemente, estão entrelaçadas, inter-relacionadas e são interdependentes, influenciando-se de forma mútua.

As políticas públicas, no sentido definido por este trabalho, exprimem a materialização dos interesses de "quem governa" e de "com quem se governa" frente aos interesses, por vezes, conflitantes dos atores que "não governam" e "para quem não se governa". Deriva desse jogo, a disputa pela construção e controle da agenda pública, dos recursos orçamentários, financeiros, humanos e estruturais para execução das ações consideradas prioritárias e dos critérios, para atendimento das demandas sociais e políticas.

$\mathrm{O}$ amadurecimento epistemológico dos conceitos que envolvem os temas ligados aos estudos das políticas públicas tornou-se relevante na proposta de Frey (2000). Em suas palavras, as instituições políticas (polity) se referem a

(...) ordem do sistema político, delineada pelo sistema jurídico, e à estrutura institucional do sistema político-administrativo, enquanto que os processos políticos (politics) adquirem uma dimensão mais processual, frequentemente de caráter conflituoso, no que diz respeito à imposição de objetivos, aos conteúdos e às decisões de distribuição. (FREY, 2000, p.216-217).

Nessa perspectiva, Frey (2000) identifica ainda uma dimensão material (policy), que se refere aos conteúdos concretos, isto é, à configuração dos programas políticos, aos problemas técnicos e ao conteúdo material das decisões políticas. Destaca ainda uma dimensão temporal, voltada inclusive para as prerrogativas de avaliação das políticas públicas, reconhecida como "policy cycle", que se revela um modelo heurístico bastante interessante, para a análise da vida de uma política pública.

Em sua análise sobre os estudos das políticas públicas no Brasil, na concepção das policy arena, que se pautam no quanto as expectativas e reações das pessoas afetadas por medidas políticas têm um efeito antecipativo para o processo político de decisão e implementação, Frey (2000) identifica quatro formas de política, a saber: 1) as políticas distributivas, 2) as políticas redistributivas, 3) políticas regulatórias e 4) 
as políticas constitutivas ou estruturadoras. Estabelece ainda que estas formas de política podem ser caracterizadas, a partir da forma e efeito dos meios de implementação aplicados, do conteúdo das políticas e do modo de resolução de conflitos políticos.

É nesse contexto que emerge a necessidade de sistematização de métodos de análise e avaliação dessas políticas públicas, pois constituem-se em ferramentas de extrema relevância para a compreensão dos processos de disputa de poder, ao passo que subsidiam a tomada de decisão dos governos e a participação dos grupos de pressão nesses processos, com significativa influência nos usos do território.

É possível identificar diversas correntes teórico-metodológicas que conferem à análise e avaliação de políticas públicas uma grande riqueza de abordagens práticas e teóricas. Como ponto de partida, pode-se resgatar a análise de Tinôco et al. (2011), que indica os principais modelos de avaliação e os paradigmas que se relacionam a cada um deles.

Nesse contexto, o primeiro modelo de avaliação identificado é o chamado modelo de avaliação tradicional, que é definido como uma avaliação técnica, que enfatiza os efeitos da política mediante pesquisa do sistema causal que busca explicar o seu funcionamento. Os autores correlacionam esse modelo de avaliação a um paradigma positivista, onde se destaca o método experimental que

(...) consiste em se estabelecer duas amostras homogêneas, uma submetida à ação pública e a outra não. Quando a política alcança a maturidade, uma medida dos efeitos a ela relacionados é operada sobre a amostra experimental, que será confrontada com o estado da outra amostra (Santos \& Verrier, 1993).

Nesse mesmo contexto de análise, Vianna (1996) resgata a proposta de modelo de avaliação de políticas públicas apresentada por Franco e Cohen (1988).

Essa proposta se pauta no entendimento de que

(...) as análises de políticas públicas podem ser de quatro tipos: investigação, investigação avaliativa, avaliação e monitoramento. Estes se diferenciam pelo momento em que são realizados (antes, durante ou depois da política); pelo objeto do estudo; pelos objetivos do estudo; pelas técnicas que empregam; e pela relação que estabelecem com a política. 
Na proposta de Franco e Cohen (1988), os estudos de avaliação das políticas públicas já implantadas (ex post) podem ser organizados em avaliação de processo e avaliação de impacto, ou seja, a avaliação de processo foca a fase de implementação de determinada política, enquanto que a avaliação de impacto se atém aos efeitos dos resultados de uma política, admitindo-se que ambas podem ocorrer durante e depois da fase de implantação (ex post), compreendendo, portanto, o cálculo do custo benefício e do custo efetivo de uma política (VIANNA, 1996).

Por outro lado, o instrumento analítico das políticas seriam as variáveis, cujo tipo de relação que estabelecem entre si definiria as políticas. As variáveis podem ser assim classificadas: variáveisparâmetro, variáveis-instrumento e variáveis-objetivo. As primeiras indicariam as condições de uma política; as segundas seriam as variáveis independentes da política; e as últimas, as dependentes da política ou que designam o objetivo da política. Por exemplo, em um projeto educacional cujo objetivo é melhorar o rendimento de um grupo de alunos, as variáveis-parâmetro ou condição seriam as condições sócio-econômicas das famílias dos alunos e os coeficientes de inteligência desses alunos; a variável-objetivo ou dependente, o rendimento dos alunos; e as variáveis-instrumento ou independentes, o estado nutricional dos alunos, os métodos pedagógicos e a infraestrutura escolar. Cada política compreende uma situação de interdependência das variáveis, ou melhor, um modelo de relação entre as variáveis, (VIANNA, 1996, p. 20).

Discorrendo especificamente sobre a avaliação de processos na proposta de Franco e Cohen (1.988), Vianna (1.996) aponta que

Seu objeto é a aferição da adequação entre meios e fins, considerando no contexto em que a política está sendo implementada os aspectos organizacional e institucional, social, econômico e político. O objetivo do estudo é permitir a correção do modelo de causalidade e, consequentemente, da implementação, visando reorientá-la em função dos objetivos propostos. (VIANNA, 1996, p.35)

Por outro lado, ao discorrer sobre a avaliação de impactos na proposta de Franco e Cohen (1988), Vianna (1996) destaca que 
A avaliação de impacto tem como objetivo determinar se houve modificação; a magnitude dessa modificação, quais segmentos afetou e em que medida; e quais foram as contribuições dos distintos componentes da política na realização dos seus objetivos. (...) Os modelos de avaliação de impacto são: experimental clássico, quaseexperimental e não experimental. (VIANNA, 1996, p36-37)

Outro ponto que deve ser destacado em relação ao modelo tradicional, destacado por Tinôco et al (2011) como uma dificuldade inerente ao paradigma positivista, refere-se ao fato de que é a expertise de um ou mais avaliadores, selecionados segundo medidas de performance anteriores que deve garantir a pertinência do conhecimento e dos julgamentos produzidos, resgatando ainda a fala de Lascoumes (1988), que sugere que a boa metodologia guarda relação com o bom expert. Fagundes e Moura (2009) afirmam que

O paradigma positivista, ainda muito presente no campo, é alvo de fortes resistências por parte de abordagens qualitativas, construcionistas e participativas. Como apontado neste artigo, a emergência destas abordagens alternativas nas últimas duas décadas teve impacto na ampliação das reflexões sobre os diferentes contextos e implicações da avaliação. As metodologias participativas, em especial, trazem novos desafios para o campo. Além de envolverem a necessidade de uma preparação pessoal e coletiva, um aprendizado das formas de participação, tais metodologias pressupõem a formação de consensos e tomada de decisões conjuntamente. Isso implica uma circulação diferenciada do poder, que não fica centrado no pesquisador/avaliador, visto como expert, mas é compartilhado com os indivíduos e as comunidades.

Tinôco et al. (2011, p.310) também chama a atenção para esse outro lado do espectro das metodologias de análise e avaliação das políticas públicas, apontando para o modelo de avaliação pluralista, assentado no paradigma do construtivismo, definido como uma metodologia onde

(...) a avaliação se transforma numa construção coletiva na qual os diversos atores envolvidos julgarão a pertinência da ação estatal e não observarão simplesmente se os efeitos da mesma estão de acordo com os objetivos iniciais.

Nesse contexto, o especialista assume um papel de facilitador de um processo mais amplo de discussão e avaliação da política que, ao contrário do paradigma positivista, privilegia as verdades relativas, em que os diferentes pontos 
de vista dos envolvidos pela política pública são considerados, ao passo em que as reações dos atores sociais (grupos de interesses e de pressão) e dos diversos contextos a que estão relacionadas devem ser consideradas pelo especialista numa avaliação coletiva.

(...) a dificuldade da escolha e formulação da metodologia permanece um problema de difícil solução, visto que a avaliação pluralista de combinar a racionalidade científica com a racionalidade política dos atores políticos. (TINÔCO et al, 2.011. p 310)

Alheia a essas dificuldades, Tinôco et al (2.011) salientam que fatores como a maior descentralização e participação de atores não governamentais em políticas de âmbito local tem contribuído para a adoção do modelo pluralista no âmbito brasileiro e de outros países, como é o caso da França.

Em outra contribuição sobre o tema, Rodrigues (2008) apresenta a proposta de avaliação de políticas públicas denominada avaliação em profundidade ou avaliação em aprofundamento. Nesse contexto, a proposta de Rodrigues (2008) é apresentada como uma resposta

(...) aos modelos de análise que buscam avaliar políticas públicas tomando como questões centrais, que orientam os instrumentos de coleta de dados, aqueles que dizem respeito única e exclusivamente ao que foi o fio condutor da formulação dessas políticas. É ainda mais cética em relação aos modelos universais, quando aplicados a contextos particulares, com total desconsideração das especificidades atinentes a cada situação e aos locais sobre os quais incidem políticas públicas formuladas nos longínquos centros de decisão, o que considero a ocorrência de um duplo distanciamento, cujos resultados são fortes omissões e/ou deslizes analíticos. (RODRIGUES, 2008. p.10).

Discorrendo a respeito dos diferentes tipos de dados e informações que deverão ser abarcados pela análise e avaliação pautada no modelo de avaliação em aprofundamento, Rodrigues (2008) destaca o uso de diversas ferramentas metodológicas, tais como:

(...) questionários em novos e variados formatos; grupos focais que inovem em relação às propostas tradicionais; entrevistas em profundidade aliadas às observações de campo; análise de conteúdo do material institucional com atenção ao suporte conceitual e às 
formas discursivas nele expressas, abordagem cultural, com compreensão dos sentidos formulados, em diferentes contextos, sobre um mesmo programa; etc.

Ao passo em que discorre sobre seu caráter multi e interdisciplinar, Rodrigues (2008) salienta inclusive que a avaliação em profundidade é obrigatoriamente extensa, detalhada, densa, ampla e multidimensional. Nesse sentido, acaba por discriminar alguns tópicos essenciais para a efetivação desse tipo de análise e avaliação de políticas públicas de caráter social:

\begin{tabular}{|c|c|}
\hline Tópicos & Aspectos \\
\hline $\begin{array}{l}1 \text { - Análise de conteúdo do } \\
\text { programa com atenção a } \\
\text { três aspectos }\end{array}$ & $\begin{array}{l}\text { Formulação: objetivos, critérios, dinâmicas de } \\
\text { implantação, acompanhamento e avaliação. } \\
\text { Bases conceituais: paradigmas orientadores e as } \\
\text { concepções e valores que os informam, bem como os } \\
\text { conceitos e noções centrais que sustentam essas } \\
\text { políticas; } \\
\text { Coerência interna: não-contradição entre as bases } \\
\text { conceituais que informam o programa, a formulação de } \\
\text { sua implementação e os itens priorizados para seu } \\
\text { acompanhamento, monitoramento e avaliação. }\end{array}$ \\
\hline $\begin{array}{l}2 \text { - Análise de contexto da } \\
\text { formulação da política }\end{array}$ & $\begin{array}{l}\text { Levantamento de dados políticos, socioeconômicos em } \\
\text { que foi formulada a política (instâncias local, regional, } \\
\text { nacional internacional e transnacional). } \\
\text { Apreensão do modelo político, econômico e social que } \\
\text { sustentou a política à sua época de formulação. } \\
\text { Levantamento de outras políticas e programa } \\
\text { correlacionados à política em foco. } \\
\text { Atenção ao marco legal que ampara a política, } \\
\text { articulando-o ao contexto referido nos itens anteriores. }\end{array}$ \\
\hline $\begin{array}{l}3 \text { - Trajetória institucional de } \\
\text { um programa }\end{array}$ & $\begin{array}{l}\text { Grau de coerência/dispersão do programa ao longo do } \\
\text { seu trânsito pelas vias institucionais. } \\
\text { Pesquisa de campo com realização de entrevistas com } \\
\text { diferentes agentes e representantes de instituições } \\
\text { envolvidas na formulação e implementação de uma } \\
\text { mesma política. } \\
\text { Atentar para os aspectos culturais inerentes a esses } \\
\text { espaços institucionais e organizacionais. }\end{array}$ \\
\hline $\begin{array}{l}4 \text { - Espectro temporal e } \\
\text { territorial }\end{array}$ & $\begin{array}{l}\text { Possibilidades de articular, na avaliação, as perspectivas } \\
\text { e objetivos de propostas generalizantes às } \\
\text { particularidades locais. } \\
\text { As possibilidades de implementação de políticas, de } \\
\text { forma localizada, que levem em conta seu percurso } \\
\text { temporal e territorial. }\end{array}$ \\
\hline
\end{tabular}

Quadro 01: Proposta de Avaliação em Profundidade de Políticas Públicas de Caráter Social. Fonte: RODRIGUES, 2008. Adaptado pelo autor. 
Em sintonia com a proposta de avaliação em profundidade, De Paula (2005) propõe a construção de novos canais de participação popular, em nível de poder local (vertente societal), pregando para isso a criação de novas relações entre estado e sociedade, sendo o primeiro auxiliado pelo segundo na coordenação política dos interesses sociais. Para o melhor entendimento dessa proposta, recorremos ao quadro a seguir:

\begin{tabular}{|c|c|}
\hline Dimensões & Características \\
\hline $\begin{array}{l}\text { Uma nova visão de } \\
\text { desenvolvimento }\end{array}$ & $\begin{array}{l}\text { Ênfase na qualidade de vida dos } \\
\text { cidadãos e expansão das capacidades } \\
\text { humanas, compreendendo que o } \\
\text { desenvolvimento - diferentemente da } \\
\text { compreensão que hegemonicamente se } \\
\text { tem do ponto de vista econômico - está } \\
\text { associado à "capacidade cultural do país } \\
\text { para formular um projeto nacional e } \\
\text { mobilizar capacidade política e } \\
\text { administrativa para implementá-lo" } \\
\text { (Sachs, 1996; 1999) }\end{array}$ \\
\hline $\begin{array}{l}\text { Concepção participativa e deliberativa de } \\
\text { democracia e gestão social }\end{array}$ & $\begin{array}{l}\text { Procura-se criar organizações } \\
\text { administrativas que } \\
\text { possibilitem a participação popular. Uma } \\
\text { gestão que tenha como princípio a } \\
\text { participação popular "contrapõe-se à } \\
\text { gestão estratégica na medida em que } \\
\text { tenta substituir a gestão tecnoburocrática, } \\
\text { monológica, por um gerenciamento mais } \\
\text { participativo, dialógico no qual o processo } \\
\text { decisório é exercido por meio de } \\
\text { diferentes sujeitos sociais" (Tenório, } \\
\text { 1998). Esta se apresenta como principal } \\
\text { característica da administração pública } \\
\text { societal, pois abre espaço para a } \\
\text { democracia participativa, permitindo a } \\
\text { incorporação de novos temas de } \\
\text { interesse público na agenda política. }\end{array}$ \\
\hline Reinvenção político-institucional & $\begin{array}{l}\text { Nesta dimensão, são abordadas a forma } \\
\text { e a dinâmica institucionais, que } \\
\text { dependendo de sua estruturação poderá } \\
\text { ou não permitir a co-gestão. E para que } \\
\text { se abranja um arranjo institucional que } \\
\text { estimule práticas democráticas, essas } \\
\text { instituições precisam ser recriadas, com o } \\
\text { objetivo de transformar as relações entre } \\
\text { Estado e sociedade. Nas experiências }\end{array}$ \\
\hline
\end{tabular}


societais, identificam-se inovações de
gestão através de fóruns temáticos,
conselhos gestores de políticas públicas
e orçamentos participativos; estruturas
que colocam em questão a tradicional
prerrogativa do Executivo do Estado de
formular e implementar as políticas
públicas, assim como abrem espaço para
que a população controle estas
denominadas políticas.

Quadro 02: Participação Societal: novas relações entre Estado e Sociedade na criação de Políticas Públicas. Fonte: De Paula (2005), adaptado pelo autor.

Convém destacar que as propostas de Tinôco et al. (2011) e Rodrigues (2008) representam uma clara tentativa de superação dos modelos tradicionais de avaliação de políticas públicas pautadas, no que denominam paradigma positivista. Contudo, julgamos necessária uma reflexão mais profunda a respeito desse posicionamento.

Compreendemos que os mecanismos de análise e avaliação de políticas públicas tradicionais não são suficientemente capazes de abarcar todas as dimensões e perspectivas que essas políticas envolvem. De fato, são portadores de várias limitações e provocam, por diversos fatores, uma dificuldade de se alcançar uma correta abstração do conteúdo dos processos em foco e/ou uma detecção mais apurada dos impactos sócio-políticos, ocasionados pela intervenção do Estado. Contudo, isso não significa necessariamente que algumas das ferramentas de análise e avaliação sob o paradigma positivista (avaliação de processo e avaliação de impacto) devam ser desconsideradas pelos especialistas em suas abordagens teórico-metodológicas, pois elas possibilitam a busca por um distanciamento estratégico do entrevistador em relação aos posicionamentos ideológicos e políticopartidários dos atores envolvidos nos fenômenos investigados, sobretudo, quando a investigação tem por objeto uma política/ação pública que tem o potencial de trazer consequências efetivas ao status quo de determinada localidade ou região, tal qual a titulação das terras quilombolas. Ao buscar critérios para observação e interpretação dos fenômenos, minimamente alheios a preferências político-partidárias ou ideológicas, preservam-se vários elementos coerentes da investigação científica e abrem-se perspectivas relevantes para a busca da qualidade teórico-metodológica 
da pesquisa, que jamais poderia ser alcançada, caso a pesquisa objetivasse, a priori, a busca pela confirmação de um discurso ideológico ou político-partidário préconcebido.

Mesmo reconhecendo que o modelo tradicional de análise não é suficiente em si para apreender todas as variantes do complexo sistema de análise e avaliação que envolvem as ações de titulação das terras quilombolas, a abordagem positivista não deve nunca ser totalmente desconsiderada, mas reposicionada quanto ao seu papel, dentro da proposta de análise e avaliação do especialista, constituindo-se numa contribuição preliminar/introdutória. Nesse contexto, o aperfeiçoamento das técnicas positivistas de análise das ações de titulação das terras quilombolas devem se tornar demandas contínuas, a fim de possibilitarem o acesso a resultados cada vez mais comprometidos com a isenção na observação dos fenômenos e processos, a partir dos dados e informações sistematizadas.

Agregando ferramentas e mecanismos ditos positivistas aos modelos construtivistas ou em profundidade, surgem diversas possibilidades de enriquecimento das metodologias de análise a serem desenvolvidas, abrindo espaço para uma nova perspectiva teórico-metodológica que dificilmente será abarcada pelos paradigmas críticos a esse tipo de abordagem.

\section{6 - Matriz de Análise e Avaliação de Políticas Públicas Territoriais}

Para se realizar a análise das ações de titulação das terras quilombolas, com todas as complexidades e peculiaridades que Ihe são características, elaborou-se uma "matriz" para a condução do processo de análise no Brasil e, mais adiante, no estado do Amapá.

Essa proposta representa a possibilidade de congregar, num único instrumento, os mecanismos e as ferramentas de análise de processos e impactos, bem como da identificação das principais virtudes, trunfos, entraves e limitações das ações, seja nas fases de formulação, planejamento ou execução, seja para abrir caminho para uma crítica propositiva, com vistas à melhoria de sua eficiência e 
eficácia, tomando como objetivo a melhoria da qualidade de vida das comunidades afrodescendentes a partir da garantia de sua segurança fundiária.

Propõem-se que as ações deva ser encaradas como um processo dividido em etapas que, em seu conjunto, possibilite uma condução lógica e racional de sua gestão. É necessário esclarecer que o estabelecimento dessas etapas é uma decisão para testar as hipóteses e atingir os objetivos de nosso trabalho e não representa, necessariamente, as diretrizes que foram estabelecidas, quando da formulação das políticas. Em outras palavras, o modelo aqui exposto é a ferramenta e o referencial de análise crítica desenvolvido pelo pesquisador, com vistas à análise das ações e não um postulado integrado à política pública em si. Assim, as etapas contidas, no esquema abaixo, representam um caminho a ser perseguido pelo pesquisador e não o caminho estipulado, quando da formulação da ação.

A matriz proposta estabelece o cumprimento de 07 etapas básicas para a análise e avaliação das ações de titulação das terras quilombolas que coincidem, em grande medida, com as próprias etapas do ciclo da política em si: formulação, planejamento, implementação, avaliação, revisão ou aperfeiçoamento, reavaliação e encerramento, conforme observado na Figura 01.

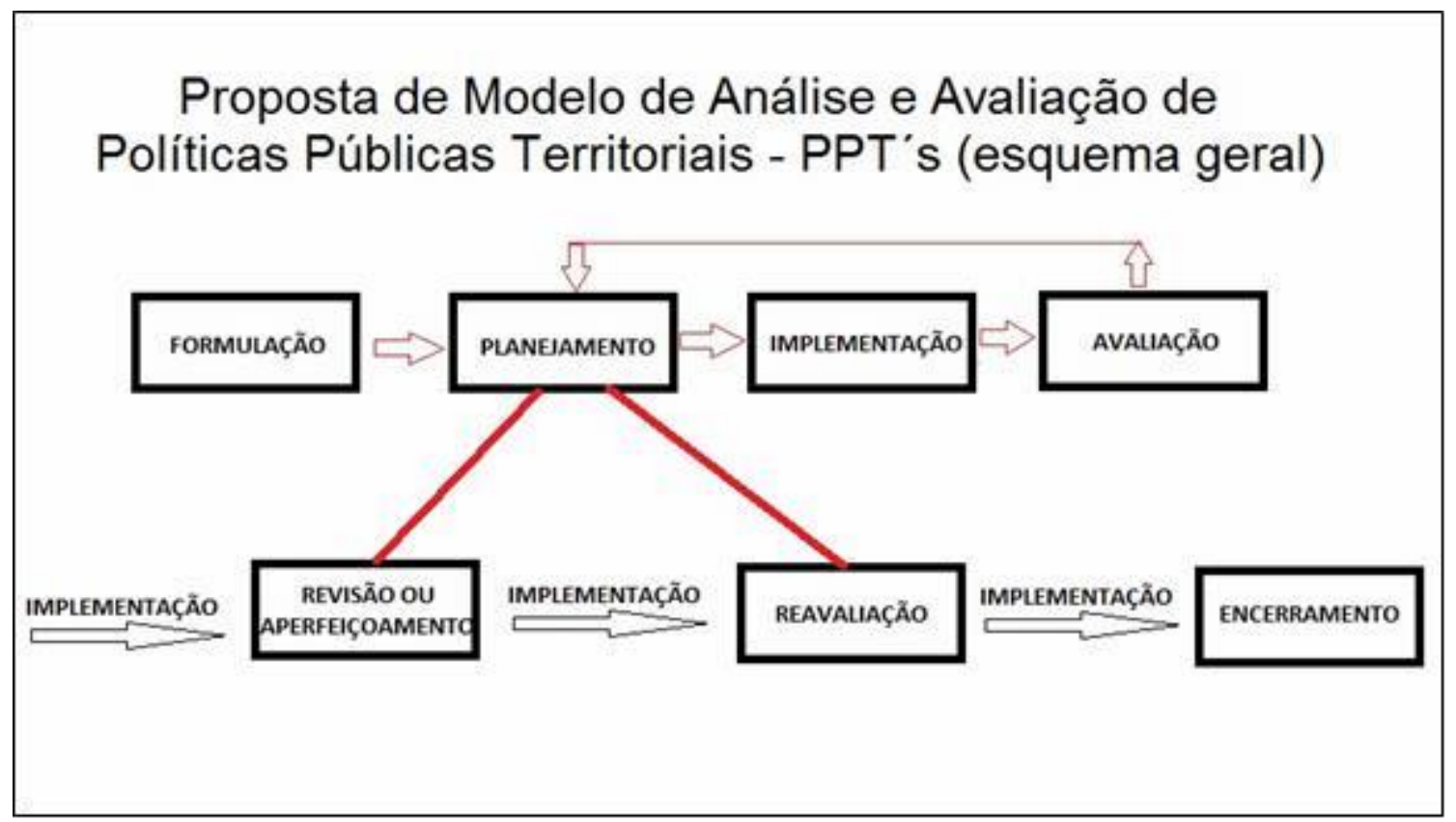

Figura 01: Modelo de Análise e Avaliação de Políticas Públicas Territoriais 
Nesse momento, é importante ressaltar que a etapa implementação subjugase, inicialmente, às etapas de formulação e planejamento. Contudo, uma vez iniciada, a implementação passa a ser considerada como algo contínuo e, por consequência, permeia também as demais etapas podendo, naturalmente, ser repensada, corrigida ou reorientada após o cumprimento das etapas da revisão e aperfeiçoamento e da etapa de reavaliação.

A etapa da formulação compreende um complexo sistema de disputas pelas agendas governamentais, que são seu ponto crítico. Nesse contexto, o poder público depara-se com a pressão de grupos, partidos, lobbys, movimentos sociais etc.. Esse estímulo pode gerar a necessidade de o poder público realizar a identificação das demandas apresentadas por esses atores. Uma vez identificadas as demandas, abre-se caminho para o levantamento e análise de custos sociais, políticos e financeiros, que a política em questão acarretaria, assim como os custos de benefícios e de oportunidades para a implementação de uma possível intervenção. Caso tal etapa seja superada, as diretrizes para a formulação da política passam a ser definidas e devem estar em sintonia com a filosofia, critérios e princípios considerados relevantes pela gestão pública, atuando a discricionariedade do Governo como o crivo principal. Havendo conveniência político-administrativa que sustente essas demandas, providencia-se a instauração do marco jurídico para sustentação legal da proposta, que, a partir de então, passa a ser considerada legalmente como uma política pública de direito, mas ainda não de fato, pois não raro políticas públicas com marco legal aprovado, encontram obstáculos institucionais e de infraestrutura para a sua efetivação prática.

No que se refere à etapa de planejamento, destaca-se a necessidade de definição de estratégias de atuação, como cronograma de execução física e eleição de métodos e técnicas de intervenção. Note que essa fase do planejamento pode ocorrer simultaneamente à etapa de formulação (diretrizes das políticas públicas territoriais), mas são atividades distintas e, por isso, são classificadas em etapas diferentes. Uma vez definidos esses termos, os recursos orçamentários (previsão), quadro de servidores e colaboradores, firmamento de contratos e/ou convênios são previstos. O ponto crítico da etapa de planejamento pauta-se pela ingerência política (muitas vezes político-partidárias) que influenciam as decisões que deveriam ser vinculadas ao princípio da impessoalidade na administração pública, o que acaba forçando muitas vezes a alteração da decisão técnica em favor de interferências 
externas ao próprio trâmite burocrático. Tal fenômeno ocorre, por exemplo, na definição da ordem em que cada uma das demandas será trabalhada: nem sempre a ordem cronológica da abertura do processo é o critério respeitado para a publicação das ordens de serviço, por exemplo.

A etapa da implementação é caracterizada pela execução física da política e a busca pelo cumprimento dos objetivos definidos nas etapas de planejamento. Por consequência, formulação e planejamentos deficientes ou equivocados, além da possível substituição do governo eleito devido ao término de mandato, por exemplo, representam grandes dificuldades na fase de implementação, que são seu ponto crítico.

A etapa de avaliação é um dos pontos chave para o sucesso da matriz proposta, pois evidencia a importância de diversos fatores que representam indicativos imprescindíveis, para uma avaliação mais aprofundada e relevante das políticas territoriais. Nesse contexto, são analisados os valores de orçamento previstos em comparação com a respectiva execução financeira, não se limitando apenas à quantidade dos recursos gastos, mas também da qualidade das ações executadas. Não obstante, a utilização de indicadores, para análise da melhoria da qualidade de vida das populações envolvidas, são fundamentais como variação do Índice de Desenvolvimento Humano - IDH, qualidade ambiental, segurança fundiária etc. Indicadores ligados à esfera produtiva e ao grau de utilização das terras também devem ser observados, como a variação do tamanho da área produtiva, volume produzido e valor da produção, assim como a assimilação de novas tecnologias produtivas. Por outro lado, melhorias acessórias também são fatores importantes para a etapa de avaliação, pois indicam como os benefícios (ou prejuízos) que a política pública em foco trouxe à população envolvida se interligam com as demais políticas públicas, como aquelas voltadas à habitação, educação, crédito produtivo, conservação ambiental etc. A solução de conflitos fundiários também deve ser considerada na etapa de avaliação, analisando inclusive o registro histórico de ocorrência desse tipo de conflito e comparando-o com as novas ocorrências, quando for o caso. O ponto crítico dessa etapa constitui-se na complexidade dos fatores a serem observados pela equipe avaliativa, bem como na sensibilidade necessária para a correta interpretação dos conflitos fundiários que serão identificados.

$\mathrm{Na}$ etapa revisão e aperfeiçoamento, as deficiências, entraves e obstáculos identificados na etapa de avaliação podem ser corrigidos ou reorientados e, de 
posse dessas informações, provocar desde pequenas ou graduais alterações ou mesmo a reformulação de todo o planejamento. Em casos mais específicos, a revisão e aperfeiçoamento do planejamento podem não ser suficientes, sendo necessário, portanto, a realização de ajustes nos critérios e/ou diretrizes estabelecidos ainda na fase de formulação da política. Não foram incluídas no bojo dessa discussão os ajustes ou reformulações, que alcancem a filosofia e princípios que sustentaram a formulação da política, pois acredita-se que, nesse caso, estaria sendo encerrada uma política e promovendo a formulação de outra.

Diferentemente da avaliação, a etapa da reavaliação conta com a inserção de novos elementos oriundos da etapa de revisão e aperfeiçoamento da política. Esse fato deverá tornar o trabalho ainda mais complexo, mas novas variáveis certamente serão incluídas na análise. Do ponto de vista metodológico, a reavaliação deverá seguir os mesmos parâmetros desenhados para a etapa de avaliação, salvo nos casos em que a etapa de revisão e aperfeiçoamento tenham avançado em elementos até então desconhecidos, quando da primeira avaliação.

$\mathrm{O}$ encerramento pode se dar a partir de diversas ações, dentre as quais podemos destacar: o cumprimento das demandas apontadas pelos grupos de interesse e presentes no escopo do projeto, que norteou a política, a alteração da filosofia e dos princípios contidos numa política anterior, a extinção da conveniência político-administrativa, a extinção do marco legal, que ampara a política. 


\begin{tabular}{|c|c|}
\hline \multicolumn{2}{|c|}{ Matriz de Análise de Ações de Titulação de Terras Quilombolas } \\
\hline Etapa & Pontos de Interesse \\
\hline Formulação & $\begin{array}{l}\text { Pressão de grupos de interesse } \\
\text { Identificação de demandas } \\
\text { Análise de custos sociais e políticos; benefícios, oportunidades. } \\
\text { Eleição de filosofia, critérios, princípios e diretrizes das políticas; } \\
\text { Conveniência político-administrativa; instauração de marco legal } \\
\\
\text { Ponto-crítico: controle de agenda }\end{array}$ \\
\hline Planejamento & $\begin{array}{l}\text { Estratégias de atuação: cronograma, métodos e técnicas de } \\
\text { intervenção, negociação de metas a serem alcançadas por período } \\
\text { e região de planejamento. } \\
\text { Recursos: previsão orçamentária, quadro de recursos humanos, } \\
\text { parcerias, contratos, convênios. } \\
\text { Ponto crítico: ingerência política em assuntos técnicos }\end{array}$ \\
\hline Implementação & $\begin{array}{l}\text { Capacidade de execução de recursos orçamentários e financeiros; } \\
\text { Capacidade de cumprimento das metas acordadas, com } \\
\text { homogeneidade regional dos resultados obtidos. } \\
\text { Ponto-crítico: etapa de planejamento equivocado ou deficiente. }\end{array}$ \\
\hline \multirow[t]{2}{*}{ Avaliação } & $\begin{array}{l}\text { Previsão Orçamentária e a Execução Financeira. } \\
\text { Meta planejada e resultado obtido } \\
\text { Identificação de obstáculos físicos, políticos, econômicos e } \\
\text { institucionais e identificação de oportunidades. } \\
\text { Regionalização de resultados e a efetividade das ações; } \\
\text { Analise da qualidade e eficiência percebida pela sociedade } \\
\text { demandante das políticas e dos demais atores envolvidos no } \\
\text { processo. } \\
\text { Análise de Indicadores de melhoria da qualidade de vida: IDH, } \\
\text { qualidade ambiental, segurança fundiária, ocorrência de eventos } \\
\text { violentos. } \\
\text { Variação da área produtiva, volume e valor da produção. } \\
\text { Melhorias acessórias: oportunidade de acesso a outras Políticas } \\
\text { Públicas (educação, habitação, crédito produtivo etc.). }\end{array}$ \\
\hline & $\begin{array}{l}\text { Gestão de conflitos fundiários, controvérsias e impasses } \\
\text { institucionais, minimização de impactos sociais às populações } \\
\text { atingidas e custos políticos da efetivação das políticas. } \\
\begin{array}{l}\text { Ponto Crítico: acordos e arranjos político-partidários e pressão da } \\
\text { base "com quem se governa". }\end{array}\end{array}$ \\
\hline $\begin{array}{c}\text { Revisão ou } \\
\text { aperfeiçoamento }\end{array}$ & $\begin{array}{l}\text { Validação de filosofia, critérios, princípios e diretrizes das políticas; } \\
\text { Conveniência político-administrativa; } \\
\text { Reavaliação de marco legal; }\end{array}$ \\
\hline
\end{tabular}




\begin{tabular}{|c|l|}
\hline Reavaliação & $\begin{array}{l}\text { Pressão de grupos de interesse; } \\
\text { Readequação de demandas; } \\
\text { Reconsideração de custos sociais e políticos; benefícios, } \\
\text { oportunidades. } \\
\text { Ponto-crítico: pressão externa pelo controle de agenda por grupos } \\
\text { sociais impactados; custos sociais e políticos da implantação das } \\
\text { ações. Mudança de Governo. }\end{array}$ \\
\hline Encerramento & $\begin{array}{l}\text { Cumprimento da demanda identificada; } \\
\text { Revisão ou reinterpretação do marco legal. }\end{array}$ \\
\hline
\end{tabular}

Quadro 03: Matriz de Análise e Avaliação de Políticas Públicas Territoriais Quilombolas

Após a exposição das principais referênciais que norteiam a matriz de análise aqui proposta, passaremos a aplicá-la nas ações de titulação das terras quilombolas. Nesse contexto, dedicaremos o próximo capítulo à consideração dos antecedentes históricos, políticos e sociais responsáveis pela criação e perpetuação das demandas territoriais e fundiárias das comunidades brasileiras afrodescendentes que convergiram, em 1988, na previsão do direito à titulação de suas terras tradicionalmente ocupadas. 


\section{CAPÍTULO II - Terras Quilombolas: aspectos históricos da luta por um direito fundamental}

A discussão a respeito da definição conceitual da expressão comunidades quilombolas e de suas terras tradicionais têm sido objeto de diversas polêmicas e debates políticos, institucionais e até mesmo acadêmicos. Em grande medida, estes impasses estão atrelados à própria dificuldade de se estabelecer um consenso a respeito das definições do termo quilombo, o que por sua vez tem sido tema de sucessivas ressignificações desde a previsão do direito fundiário das comunidades no texto constitucional de 1988. A compreensão dos fundamentos históricos que permeiam esse debate é o objetivo deste capítulo e, para tal, realizaremos uma leitura do processo de formação das territorialidades étnicas quilombolas no Brasil e no continente americano, bem como da atuação do movimento negro organizado na questão territorial que envolve as comunidades negras no Brasil para, a partir dai, compreendermos as motivações e o contexto político e social da previsão desse direito na Constituição de 1988.

\section{1 - Gênese dos processos de formação das territorialidades étnicas no Brasil e continente americano}

A compreensão do processo histórico de formação das demandas territoriais das comunidades tradicionais quilombolas no Brasil está vinculada a um contexto mais abrangente, relacionado ao sistema escravocrata que se instalou no processo de colonização das Américas. Conforme explica Price (1992), no contexto da própria formação do Novo Mundo:

(...) o homem que se tornaria o primeiro maroon afro-americano chegou na década do desembarque de Colombo, no primeiro navio de escravos que desembarcou nas Américas. (Tradução nossa) 
Para Reis e Gomes (2001, tradução nossa)

(...) o trafico de escravos para a América consumiu a vida de cerca de 12 milhões de homens e mulheres africanos, representando um dos mais importantes empreendimentos culturais e comerciais na criação do sistema econômico mundial.

Price (1992) salienta que, por mais de quatro séculos, essas comunidades foram formadas a partir da fuga de escravos que eram explorados nas plantation das Américas, do Brasil ao sudeste dos Estados Unidos, do Peru ao sudoeste da América:

Conhecidos de forma variada, como palenques, quilombos, mocambos, cumbes, mambises ou ladeiras, essas novas sociedades variaram de pequenos bandos que sobreviveram menos de um ano para estados poderosos que englobavam milhares de membros que sobreviveram por gerações e até séculos. Hoje, seus descendentes ainda formam enclaves semi-independentes em várias partes do hemisfério - por exemplo, no Suriname, Guiana Francesa, Jamaica, Colômbia e Belize - orgulhosos de suas origens negras e, em alguns casos pelo menos, fiel a uma cultura tradicional única, forjada durante os primeiros dias da história afro-americana. (PRICE, 1992. Tradução nossa)

A gênese do processo histórico de configuração do que nossa legislação compreende atualmente como os territórios históricos de resistência de escravos fugitivos é identificado, no contexto abordado por Price (1992), como fruto da busca por áreas inóspitas e de difícil acesso para que, assim, encontrassem refúgio e liberdade:

No sul dos Estados Unidos, os pântanos isolados eram os lugares favoritos. Na Jamaica, um dos grupos maroons mais famosos 
viveram nos "cockpit country", onde profundos cânions e dolinas em pedra calcária são abundantes, mas onde água e solos férteis são escassos. E nas Guianas, aparentemente, as florestas impenetráveis forneceu segurança aos maroons. (PRICE, 1992. Tradução nossa).

Contudo, ainda no contexto abordado pelo autor, várias foram as formas empregadas para tentar manter os limites desses territórios de refúgio e a liberdade dos negros que ai habitavam, mas reconhece como típicos os acordos estabelecidos com "a sociedade branca" no Brasil, Colômbia, Cuba, Equador, Jamaica, México e Suriname, em que:

(...) propôs-se às comunidades maroons sua liberdade, o reconhecimento de sua integridade territorial e criou-se algumas provisões para atender às suas necessidades econômicas. Em troca, os tratados exigiam que os maroons acabassem com todas as hostilidades em relação às plantations, devolvessem todos os futuros fugitivos e, muitas vezes, ajudassem os brancos a caçá-los. (PRICE, 1992. Tradução nossa)

O autor salienta que, obviamente, algumas comunidades nunca alcançaram esse tipo de acordo, sendo esmagadas por ataques armados, assim como, por outro lado, alguns tratados propostos foram rapidamente sendo recusados ou violados.

No entanto, novas comunidades maroons apareciam quase tão rapidamente quanto as antigas eram exterminadas, e eles permaneceram, de uma perspectiva colonial, a "praga crônica" e a "gangrena" de muitas sociedades de plantation até a Emancipação final. (PRICE, 1992. Tradução nossa)

Abordando especificamente o caso Brasileiro, Reis e Gomes (2001) estimam que $40 \%$ dos negros importados para as Américas foram parar no Brasil, direcionados às atividades ligadas às plantations, fazendas, ranchos, minas, cidades, fábricas e trabalhos domésticos. Constituíram, assim, o que denominaram "o esqueleto econômico do Brasil durante os primeiros quatro séculos de sua

\footnotetext{
Segundo a Enciclopédia Britânica, trata-se de uma região de aproximadamente $1.300 \mathrm{~km}^{2}$ no interior da Jamaica. É parte da grande platô de calcário branco e tem uma topografia cárstica típica, com inúmeras colinas cônicas e esféricas cobertas com densa vegetação acima das depressões e dos poços (dolinas) com vertentes íngremes - os "cockpits". Fonte: $<$ www.britannica.com/place/Cockpit-Country>
} 
história, começando pela ocupação portuguesa do século XVI" (REIS e GOMES, 2001. Tradução nossa).

Essas situações demonstram um contexto histórico em que as relações de poder político e econômico eram determinantes para a configuração de um quadro geopolítico extremamente negativo aos direitos que hoje consideramos como fundamentais para a pessoa humana, tais como aqueles evocados pela Organização das Nações Unidas (ONU), a partir da Convenção no107 e 169 da Organização Internacional do Trabalho (OIT), que é a base para a garantia dos direitos das comunidades tribais.

\section{2 - Direitos Étnicos Territoriais das Comunidades Quilombolas no Brasil: da constituição da demanda à demanda constitucional}

Para que se possa compreender as demandas pela regularização das terras das comunidades quilombolas espalhadas pelo Brasil, é preciso resgatar o percurso histórico, político e jurídico, que convergiu na garantia constitucional desses direitos na Constituição de 1988 e, a partir daí, na legislação quilombola, atualmente, em vigor, especialmente o Decreto 4.887 de 20 de novembro de 2003 e da Instrução Normativa INCRA nำ57, de novembro de 2009. Essa reflexão será iniciada, a partir da análise da questão dos direitos étnicos territoriais das populações negras, nos textos constitucionais e normativos do arcabouço jurídico nacional.

A primeira constatação é a de que as constituições brasileiras sempre reservaram lugar ao tratamento das questões ligadas à igualdade. Mesmo na Constituição de 1824, outorgada pelo Império ainda sob o regime escravocrata, a igualdade perante a lei era objeto do Artigo 179 XIII: A lei será igual para todos, quer proteja, quer castigue, e recompensará em proporção dos merecimentos de cada um. Contudo, conforme destaca Baraviera (2005, p.02)

O negro situava-se em região limítrofe entre coisa e pessoa, mas na pior das situações, pois seu interesse era o último que prevalecia, ou seja, conforme o interesse dos senhores, o negro adquiria e perdia sua precária personalidade. Para efeitos penais, na condição de autor de delito, o negro era responsável - característica inerente à 
personalidade jurídica, sofrendo as penalidades legais. Quando assumia a condição de vítima, o negro voltava a ser mera coisa.

O Código Penal de 1830, sob a égide da Constituição de 1824, classifica e manda executar penas referentes aos então escravos, que promovessem a chamada Insurreição, ao qual dedica-se o Capítulo IV:

Art. 113. Julgar-se-ha commettido este crime, retinindo-se vinte ou mais escravos para haverem a liberdade por meio da força. Penas Aos cabeças - de morte no gráo maximo; de galés perpetuas no médio; e por quinze annos no minimo; - aos mais - açoutes.

Art. 114. Se os cabeças da insurreição forem pessoas livres, incorrerão nas mesmas penas impostas, no artigo antecedente, aos cabeças, quando são escravos.

Art. 115. Ajudar, excitar, ou aconselhar escravos a insurgir-se, fornecendo-lhes armas, munições, ou outros meios para o mesmo fim. Penas - de prisão com trabalho por vinte annos no gráo maximo; por doze no médio; e por oito no minimo.

Ainda sob a Constituição Imperial, vale destacar o teor da Lei no 04 de 10 de Junho de 1835, que "Determina as penas com que devem ser punidos os escravos, que matarem, ferirem ou commetterem outra qualquer offensa physica contra seus senhores, etc.; e estabelece regras para o processo", prevendo inclusive que:

Art. $1^{\circ}$ Serão punidos com a pena de morte os escravos ou escravas, que matarem por qualquer maneira que seja, propinarem veneno, ferirem gravemente ou fizerem outra qualquer grave offensa physica a seu senhor, a sua mulher, a descendentes ou ascendentes, que em sua companhia morarem, a administrador, feitor e ás suas mulheres, que com elles viverem. Se o ferimento, ou offensa physica forem leves, a pena será de açoutes a proporção das circumstancias mais ou menos aggravantes.

A Lei $n^{\circ} 04$ de 10 de Julho de 1835 só veio a ser parcialmente revogada, "na parte em que impõem a pena de açoute”, pela Lei 3.310 de 15 de Outubro de 1886.

Contudo, um período histórico significativo para a compreensão do papel do negro no sistema social agrário brasileiro compreende justamente na segunda metade do Séc. XIX, quando se dão dois movimentos importantes para a vida do negro, seja ele livre ou cativo. O primeiro ponto é representado pela Lei no 601 de 20 
de setembro de 1850, a chamada Lei de Terras.

\begin{abstract}
A Lei de Terras de 1850 e seu respectivo regulamento de 1854 possibilitou a normatização agrária que o Brasil precisava, embora, se conteste o seu caráter de expropriação das camadas menos favorecidas. (...) foi o resultado de toda uma reorganização da questão agrária brasileira, buscando adaptar-se às exigências do avanço do capitalismo, juntamente com a necessidade de promover um ordenamento jurídico da propriedade da terra no Brasil, já que desde os tempos de colônia a situação era confusa. (TAGLIETTI, 2005, p.03)
\end{abstract}

Para que se compreenda o teor da afirmação de Taglietti (2005) é necessário ressaltar que esse ato legislativo se deu no contexto do Segundo reinado, em que não se haviam criado instrumentos para se conhecer quem eram os donos das terras particulares no Brasil, sendo elas concessões por sesmarias ou posses reconhecidas pelo Império. Era urgente, portanto, haver um sistema de cadastro de ocupantes e ordenamento do território imperial brasileiro. Além disso, também era muito forte a pressão externa sofrida pelo Brasil para que estabelecesse o fim do trabalho escravo, pressões estas vindas especialmente Inglaterra.

Para Gadelha (1989), tratava-se do início de um processo tardio de mercantilização da terra, o que seria parte de um projeto elitista de transição para o trabalho livre. Assim, era necessário preparar o país para as mudanças que estavam se processando no sistema produtivo da época, ou seja, o caminho para o fim da escravidão, liberação dessa mão-de-obra e a necessidade de substituição da mesma (TAGLIETTI, 2005).

Se uma das questões centrais da lei era a preocupação em substituir a mão-de-obra escrava, havia um expediente muito significativo para a segunda metade do século XIX, que era a expansão da economia cafeeira, ou seja, a expansão de lavoura requeria terra e a garantia do fornecimento de mão-de-obra. (TAGLIETTI, 2005, p.08)

No bojo dessa modernização do ordenamento agrário brasileiro, promovido pelo Estado Imperial sob os interesses evidentes das classes oligárquicas da cada vez mais importante lavoura cafeeira, estava a instituição do fim da possibilidade de aquisição de terras públicas que não fosse a partir de compra, ou seja, não haveria 
mais a possibilidade de haver a doação de sesmarias ou emissão títulos públicos pela simples ocupação (cultivo e morada habitual na área, basicamente), que eram as alternativas vigentes até então. Desta forma, as terras devolutas ou públicas seriam, a partir da Lei de Terras, adquiridas somente a partir da compra direta junto ao Estado, o que excluía do processo a maior parcela da miserável população brasileira mantendo-a, portanto, ainda dependente dos grandes fazendeiros, mas a partir de vínculos de trabalho:

Face a esta sociedade, o homem livre, lavrador ou de ofício, achavase impossibilitado de manter sua independência, perante uma organização econômico-social, que exigia a submissão dos indivíduos ao direito da propriedade do solo. (GADELHA, 1989, p. 156)

Dentre os grupos sociais impactados por essas mudanças na legislação agrária, os negros eram os mais prejudicados pois, se por um lado todo esse processo convergiria na Abolição da Escravidão em 1888, por outro essa libertação da condição de cativo não veio acompanhada de nenhuma política de reparação, indenização ou inserção em algum tipo de programa de colonização para conferirIhes um lugar social digno. Esta havia sido uma preocupação de alguns setores do movimento abolicionista, tendo inspirado inclusive a proposta de André Pinto Rebouças, a qual Marangoni (2011) discorre a respeito, sintetizando que:

(...) grandes proprietários venderiam ou alugariam lotes de terras a libertos, imigrantes e lavradores. Trata-se de uma modalidade de reforma que prescinde da democratização fundiária, restringindo-se às regras do mercado então vigentes. Quando a campanha abolicionista tomou vulto, tais propostas foram pouco a pouco sendo deixadas de lado.

Evidentemente que foram deixadas de lado pois o bem estar social do negro não era exatamente o cerne da questão a ser resolvida, mas os interesses dos setores oligárquicos que dominavam o cenário político à época. Ao contrário, o que se vê na Lei é a clara opção pela substituição da mão-de-obra do negro cativo pelo imigrante europeu assalariado, empreitada que foi, inclusive, financiada pelo Estado a partir da venda das próprias terras devolutas que "sobravam" das demarcações das terras 
particulares (sesmarias, posses etc.).

Gerações inteiras de famílias negras foram assim expulsas das fazendas em que eram cativas para vilas ou cidades para tentar algum tipo de sobrevivência na economia urbana, enquanto outros grupos migraram para áreas cada vez mais inóspitas do território nacional, buscando lugares onde a mão do homem branco ou do Estado não os alcançava e, nesses refúgios, se estabeleciam e muitos prosperavam. Em Minas Gerais, por exemplo, é comum ouvir relatos de quilombolas que se lembram de histórias de comunidades de escravos libertos e seus descendentes que se formaram neste período e buscaram se instalar em áreas endêmicas de malária, por exemplo, que eram evitadas pelo homem branco. O problema é que, com o passar do tempo, aquelas terras antes remotas, inóspitas e insalubres eram alcançadas pelas fronteiras agrícolas e se tornavam, portanto, mais valorizadas e visadas. Assim, como os negros não tinham condições de acumular recursos financeiros para comprar aquelas terras do Estado e se tornarem os "legítimos proprietários" das mesmas, acabavam cedendo a pressões da expansão agrícola e se viam obrigados literalmente a abandoar suas ocupações, em muitas vezes depois de resistirem, buscando novas áreas ainda mais remotas, inóspitas e insalubres e, assim, recomeçava o círculo vicioso.

No que se refere à primeira Constituição Republicana, de 1891, Baraviera (2005, p.03) destaca que

(...) houve forte repulsa ao regime monárquico que antecedeu à República, afastando-se os privilégios dos títulos de nobreza, mas não há maior preocupação com a igualdade racial. Ao contrário. Nos incisos $1^{\circ}$ e $2^{\circ}$ do $\S 2^{\circ}$ do art. 70 , são excluídos dos direitos políticos mendigos e analfabetos, condição da grande maioria dos recémlibertos.

A Constituição de 1934, porém, inova ao inserir pela primeira vez a palavra raça num texto constitucional Brasileiro. Baraviera (2005, p.04) afirma que

Vê-se um avanço no texto ao mencionar expressamente a questão racial. Todavia, o avanço nesse aspecto é diluído em outras não menos importantes conquistas sociais, como a igualdade por motivo de sexo (conquista feminina), religião ou política. Mas mais significativo é que, embora pregasse a igualdade, incluída a de raça, a Constituição guardava os ranços do preconceito: "Art. $121 \ldots \S 6^{\circ} \mathrm{A}$ 
entrada de immigrantes no território nacional soffrerá as restricções (...) necessárias à garantia da integração ethnica e capacidade physica e civil do immigrante... Art. 138. Incumbe à União, aos Estados e aos Municípios, nos temos das leis respectivas: b) estimular a educação eugênica". De forma quase expressa, o texto demonstra que os imigrantes seriam bem aceitos somente se pertencessem a etnias ditas "superiores", com padrões físicos desejáveis, o que novamente excluiria, dentre outros, o negro.

Baraviera (2005, p.05) segue sua análise sobre a questão racial nas constituições brasileiras e passa a analisar a Constituição de 1937 que,

(...) como as outras, propalou a igualdade no item 2 do art. 122, mas não fez menção expressa à raça. Curioso retrocesso. Sabe-se que a Constituição também deve ser observada em seu aspecto sociológico, ou seja, é preciso enxergar a eficácia das disposições. Nesse sentido, não parece haver diferença entre a Constituição de 1934, que falava em igualdade de raça e eugenia, e a de 1937, que aboliu a palavra raça, pois ambas carregavam preconceitos e, pela exiguidade de tempo entre uma e outra, não se pode esperar mudanças de mentalidade e comportamento social. Contudo, observada a evolução histórica do país e do texto constitucional, a mera inserção da palavra raça já configurava uma vitória.

A respeito da Constituição de 1946, Baraviera (2005) destaca que foi omissa em relação à igualdade de raça, enquanto que reconhece um grande avanço nas Constituições seguintes, de 1967 e 1969:

Não só voltou o vocábulo raça, como se mencionou a punição contra o preconceito. O texto é similar nas duas Cartas, estando no $\S 1^{\circ}$ do art.150 da Constituição de 1967, e no $\$ 1^{\circ}$ do art. 153 da Constituição de 1969: §1ํㅡ Todos são iguais perante a lei, sem distinção de sexo, raça, trabalho, credo religioso e convicções políticas. Será punido pela lei o preconceito de raça.

Se a questão da igualdade racial se mostra intermitente na história constitucional brasileira, não se observa, até o texto constitucional de 1969, menção alguma ao atendimento de qualquer tipo de demanda territorial ou mesmo fundiária que abarcasse as populações negras. 


\title{
2.3 - Movimento Negro e a Questão Quilombola.
}

\author{
Referindo-se aos movimentos políticos e sociais, que antecederam os \\ processos que culminaram com a inclusão da questão negra na Constituição de \\ 1988, Treccani² (2005) destaca que:
}

\begin{abstract}
Ainda nos anos 30 e 40 do século passado, a Frente Negra Brasileira abriu o debate sobre a questão do negro, defendendo que a abolição tinha sido "um processo inacabado", que o estado brasileiro tinha uma "dívida" a ser redimida. A ideia de uma "reparação" era apresentada como uma necessidade histórica. Essa dívida apresentava duas dimensões: aquela dos senhores que, ao longo dos séculos, se tinham beneficiado gratuitamente do trabalho escravo, e aquela que perdurava ainda, apesar da igualdade formal garantida pelo ordenamento jurídico, que era o estigma de ser negro, fato que gerava novas situações de exclusão. A luta antirracista levava à necessidade de elaboração de políticas de reparação.
\end{abstract}

Nesse contexto, não é necessário muito esforço para perceber que os textos constitucionais, que precederam a Constituição de 1988, sequer cogitaram a garantia dos direitos específicos das populações negras no Brasil, quanto menos das garantias da regularização fundiária a essas comunidades descendentes dos quilombos. Todavia, sobre o texto constitucional de 1988, Treccani (2005) destaca que

(...) incluiu, entre os objetivos fundamentais da República Federativa do Brasil (art. $3^{\circ}$, IV): "promover o bem de todos, sem preconceitos de origem, raça, sexo, cor, idade e quaisquer formas de discriminação (original sem grifo)". Apesar do combate ao racismo integrar os direitos fundamentais, sendo considerado crime inafiançável (art. $5^{\circ}, \mathrm{XLII}$ ), essa igualdade formal não conseguiu mudar o quadro de marginalização sofrida pelos negros. Uma nova experiência de reconhecimento efetivo de direito se deu por meio do art. 68 do ADCT, que possibilita a transformação das posses em domínio.

\footnotetext{
${ }^{2}$ Não foi possível ter acesso à obra física do referido autor, apenas à um arquivo referente à transcrição do original, mas que não conserva sua paginação, razão pela qual não disponibilizamos esta informação nas referências ao longo do texto.
} 
Sobre esse mesmo contexto, Rodrigues (2010) fala de uma cidadania de baixo para cima, afirmando que

\begin{abstract}
Esse período é emblemático para os movimentos sociais de forma geral, os quais se fortalecem no cenário de redemocratização do país. (...) No que tange aos movimentos negros, esse período demarca uma nova fase de sua atuação política, pois ultrapassa o viés da denúncia para investir na proposição de políticas públicas. Essa dinâmica em relação ao Estado tem sido marcada por avanços e recuos na resposta governamental, além do reflexo disso no seio dos próprios movimentos. Os principais fatos dessa dinâmica se dão ao longo dos mandatos presidenciais de três governos: José Sarney (1985-1990); Fernando Henrique Cardoso (1995-1999) e (19992003); Luiz Inácio Lula da Silva (2003-2007) e (2007-2011). (RODRIGUES, 2010, p. 267-8)
\end{abstract}

Avançando pelo contexto da fala de Rodrigues (2010), é importante citar o papel histórico desempenhado pelo movimento negro organizado no Brasil, em suas mais diversas facetas e períodos, na luta pela garantia dos direitos dessas populações, pois foi a importante e decisiva contribuição desses movimentos que convergiram na inclusão dos direitos étnicos territoriais das comunidades quilombolas no texto constitucional de 1988.

O trabalho de Domingues (2007) sintetiza, de forma esquemática e sistematizada, a identificação e trajetória do movimento negro no período republicano, contemporizando, contudo, que "a evolução histórica desse movimento não foi estanque ou linear; ao contrário, foi marcada por contradições, avanços, recuos e estagnações de diversas ordens" (DOMINGUES, 2007, p. 119).

O quadro foi organizado a partir da identificação de, pelo menos, três fases do Movimento Negro Brasileiro no período republicano: Primeira Fase - 1889 a 1937; Segunda Fase - 1945 a 1964; Terceira Fase - 1978 a 2000. Os pontos de convergência ou divergência político-ideológicas adotados como critérios de classificação foram os posicionamentos quanto à conjuntura internacional, termos de autoidentificação, seu entendimento a respeito das causas da marginalização do negro, suas propostas para solução do racismo, os métodos de lutas que consagraram, sua própria relação com o mito da democracia racial, as capacidades de mobilização que alcançaram, sua relação com a cultura negra, seu entendimento 
sobre a cultura da mestiçagem, o dia para reflexão ou protesto no tocante à sua condição étnica e as principais lideranças que despontaram nos seus quadros, conforme pode ser observado no Quadro 04: 


\begin{tabular}{|c|c|c|c|}
\hline $\begin{array}{c}\text { Movimento Negro } \\
\text { Brasileiro }\end{array}$ & $\begin{array}{c}\text { Primeira Fase } \\
(1889-1937)\end{array}$ & $\begin{array}{c}\text { Segunda Fase } \\
(1945-1964)\end{array}$ & $\begin{array}{c}\text { Terceira Fase } \\
(1978-2000)\end{array}$ \\
\hline Principais Entidades & $\begin{array}{c}\text { Frente Negra } \\
\text { Brasileira - FNB }\end{array}$ & $\begin{array}{c}\text { União dos Homens } \\
\text { de Cor - Uagacê - } \\
\text { UHC } \\
\text { Teatro Experimental } \\
\text { do Negro - TEN }\end{array}$ & $\begin{array}{l}\text { Movimento Negro } \\
\text { Unificado - MNU }\end{array}$ \\
\hline $\begin{array}{c}\text { Tipo de Discurso } \\
\text { Racial Predominante }\end{array}$ & Moderado & Moderado & Contundente \\
\hline $\begin{array}{l}\text { Estratégia Cultural } \\
\text { de Inclusão }\end{array}$ & Assimilacionista & Integracionista & $\begin{array}{c}\text { Diferencialista } \\
\text { (igualdade na } \\
\text { diferença) }\end{array}$ \\
\hline $\begin{array}{c}\text { Principais princípios } \\
\text { ideológicos e } \\
\text { posições políticas }\end{array}$ & $\begin{array}{c}\text { Nacionalismo e } \\
\text { defesa das forças } \\
\text { políticas de "direita" } \\
\text { nos anos } 1930\end{array}$ & $\begin{array}{c}\text { Nacionalismo e } \\
\text { defesa das forças } \\
\text { políticas de "centro" e } \\
\text { de "direita" nos anos } \\
\text { de } 1940 \text { e } 1950\end{array}$ & $\begin{array}{c}\text { Internacionalismo e } \\
\text { defesa das forças } \\
\text { políticas de } \\
\text { "esquerda } \\
\text { marxista", nos } \\
\text { anos } 1970 \text { e } 1980\end{array}$ \\
\hline $\begin{array}{l}\text { Conjuntura } \\
\text { internacional }\end{array}$ & $\begin{array}{c}\text { Movimento } \\
\text { nazifascista e } \\
\text { pan-africanista }\end{array}$ & $\begin{array}{c}\text { Movimento da } \\
\text { negritude e de } \\
\text { descolonização da } \\
\text { África }\end{array}$ & $\begin{array}{c}\text { Afrocentrismo, } \\
\text { movimento dos } \\
\text { direitos civis nos } \\
\text { Estados Unidos e } \\
\text { de } \\
\text { descolonização da } \\
\text { África }\end{array}$ \\
\hline $\begin{array}{l}\text { Principais termos de } \\
\text { auto-identificação }\end{array}$ & $\begin{array}{l}\text { Homem de cor, } \\
\text { negro e preto }\end{array}$ & $\begin{array}{l}\text { Homem de cor, } \\
\text { negro e preto }\end{array}$ & $\begin{array}{l}\text { Adoção "oficial" } \\
\text { do termo "negro". } \\
\text { Posteriormente, } \\
\text { usa-se, também, o } \\
\text { "afro-brasileiro" e } \\
\text { "afrodescendente" }\end{array}$ \\
\hline $\begin{array}{c}\text { Causa da } \\
\text { marginalização do } \\
\text { negro }\end{array}$ & $\begin{array}{c}\text { A escravidão e o } \\
\text { despreparo moral/ } \\
\text { educacional }\end{array}$ & $\begin{array}{c}\text { A escravidão e o } \\
\text { despreparo cultural/ } \\
\text { educacional }\end{array}$ & $\begin{array}{l}\text { A escravidão e o } \\
\text { sistema capitalista }\end{array}$ \\
\hline $\begin{array}{c}\text { Solução para o } \\
\text { racismo }\end{array}$ & $\begin{array}{l}\text { Pela via educacional } \\
\text { e moral, nos marcos } \\
\text { do capitalismo ou da } \\
\text { sociedade burguesa }\end{array}$ & $\begin{array}{l}\text { Pela via educacional } \\
\text { e cultural, } \\
\text { eliminando o } \\
\text { complexo de } \\
\text { inferioridade do } \\
\text { negro e reeducando } \\
\text { racialmente o } \\
\text { branco, nos marcos } \\
\text { do capitalismo ou } \\
\text { sociedade burguesa }\end{array}$ & $\begin{array}{c}\text { Pela via política } \\
\text { ("negro no poder!"), } \\
\text { nos marcos de } \\
\text { uma } \\
\text { sociedade } \\
\text { socialista, } \\
\text { a única que seria } \\
\text { capaz de eliminar } \\
\text { com todas as } \\
\text { formas de } \\
\text { opressão, } \\
\text { inclusive a racial }\end{array}$ \\
\hline Métodos de lutas & $\begin{array}{l}\text { Criação de } \\
\text { agremiações negras, } \\
\text { palestras, atos } \\
\text { públicos "cívicos" e } \\
\text { publicação de jornais }\end{array}$ & $\begin{array}{c}\text { Teatro, imprensa, } \\
\text { eventos } \\
\text { "acadêmicos" e } \\
\text { ações visando à } \\
\text { sensibilização da } \\
\text { elite branca para o } \\
\text { problema do negro }\end{array}$ & $\begin{array}{c}\text { Manifestações } \\
\text { públicas, imprensa, } \\
\text { formação de } \\
\text { comitês } \\
\text { de base, formação } \\
\text { de um movimento } \\
\text { nacional }\end{array}$ \\
\hline
\end{tabular}




\begin{tabular}{|c|c|c|c|}
\hline & & no país & \\
\hline $\begin{array}{c}\text { Relação com } \\
\text { o "mito" da } \\
\text { democracia racial }\end{array}$ & $\begin{array}{c}\text { Denúncia } \\
\text { assistemática } \\
\text { do "mito" da } \\
\text { democracia racial }\end{array}$ & $\begin{array}{c}\text { Denúncia } \\
\text { assistemática } \\
\text { do "mito" da } \\
\text { democracia racial }\end{array}$ & $\begin{array}{c}\text { Denúncia } \\
\text { sistemática } \\
\text { do "mito" da } \\
\text { democracia racial }\end{array}$ \\
\hline $\begin{array}{l}\text { Capacidade de } \\
\text { mobilização }\end{array}$ & $\begin{array}{l}\text { Movimento social } \\
\text { que chegou a ter um } \\
\text { caráter de massa }\end{array}$ & $\begin{array}{c}\text { Movimento social de } \\
\text { vanguarda }\end{array}$ & $\begin{array}{c}\text { Movimento social } \\
\text { de } \\
\text { Vanguarda }\end{array}$ \\
\hline $\begin{array}{l}\text { Relaç } \\
\text { "cultı }\end{array}$ & $\begin{array}{l}\text { Distanciamento } \\
\text { frente alguns } \\
\text { símbolos associados } \\
\text { à cultura negra } \\
\text { (capoeira, samba, } \\
\text { religiões de matriz } \\
\text { africana) }\end{array}$ & $\begin{array}{c}\text { Ambigüidade } \\
\text { valorativa diante } \\
\text { de alguns símbolos } \\
\text { associados à cultura } \\
\text { negra (capoeira, } \\
\text { samba, religiões de } \\
\text { matriz africana) }\end{array}$ & $\begin{array}{l}\text { Valorização dos } \\
\text { símbolos } \\
\text { associados } \\
\text { à cultura negra } \\
\text { (capoeira, samba, } \\
\text { religiões de matriz } \\
\text { africana, sobretudo } \\
\text { o } \\
\text { candomblé) }\end{array}$ \\
\hline $\begin{array}{l}\text { Como concebiam } \\
\text { o fenômeno da } \\
\text { mestiçagem }\end{array}$ & $\begin{array}{c}\text { De maneira positiva } \\
\text { (discurso } \\
\text { prómestiçagem) }\end{array}$ & $\begin{array}{c}\text { De maneira positiva } \\
\text { (discurso } \\
\text { prómestiçagem) }\end{array}$ & $\begin{array}{c}\text { De maneira } \\
\text { negativa } \\
\text { (discurso contra a } \\
\text { mestiçagem) }\end{array}$ \\
\hline $\begin{array}{c}\text { Dia de reflexão e/ou } \\
\text { protesto }\end{array}$ & $\begin{array}{l}13 \text { de Maio (dia da } \\
\text { assinatura da Lei } \\
\text { Áurea, em 1888) }\end{array}$ & $\begin{array}{l}13 \text { de Maio (dia da } \\
\text { assinatura da Lei } \\
\text { Áurea, em 1888) }\end{array}$ & $\begin{array}{c}20 \text { de Novembro } \\
\text { (dia } \\
\text { de rememoração } \\
\text { da } \\
\text { morte de Zumbi } \\
\text { dos } \\
\text { Palmares) }\end{array}$ \\
\hline Principais lideran & $\begin{array}{c}\text { Vicente Ferreira, } \\
\text { José Correia Leite, } \\
\text { Arlindo Veiga dos } \\
\text { Santos }\end{array}$ & $\begin{array}{l}\text { José Bernardo da } \\
\text { Silva, Abdias do } \\
\text { Nascimento }\end{array}$ & $\begin{array}{l}\text { Hamilton Cardoso, } \\
\text { Lélia Gonzalez }\end{array}$ \\
\hline
\end{tabular}

Quadro 04: Movimento Negro Brasileiro: fases e características.

Fonte: Domingues, P. (2007, p. 118-9)

(Adaptado pelo autor).

No que se refere ao Movimento Negro Unificado (MNU), Domingues (2007, p. 112) aponta que sua fundação, em 1978, representou a volta à cena política brasileira de um movimento negro organizado, após os primeiros anos da Ditadura Militar. Sobre o contexto de sua fundação, Domingues (2007, p. 112) aponta que

No plano externo, o protesto negro contemporâneo se inspirou, de um lado, na luta a favor dos direitos civis dos negros estadunidenses, onde se projetaram lideranças como Martin Luther King, Malcon X e organizações negras marxistas, como os Panteras Negras, e, de outro, nos movimentos de libertação dos países africanos, sobretudo de língua portuguesa, como Guiné Bissau, Moçambique e Angola. Tais influências externas contribuíram para o Movimento Negro Unificado ter assumido um discurso radicalizado contra a discriminação racial. No plano interno, o embrião do Movimento 
Negro Unificado foi a organização marxista, de orientação trotskista, Convergência Socialista. Ela foi a escola de formação política e ideológica de várias lideranças importantes dessa nova fase do movimento negro. Havia, na Convergência Socialista, um grupo de militantes negros que entendia que a luta antirracista tinha que ser combinada com a luta revolucionária anticapitalista.

Domingues (2007) explica que, na concepção do MNU, o racismo era um dos produtos do capitalismo e que a superação do primeiro só viria com a queda do segundo, a partir da construção de uma sociedade igualitária, numa política que conjugava raça e classe. Referindo-se ao Programa de Ação do MNU de 1982, Domingues (2007, p. 114) relata que

(...) o MNU defendia as seguintes reivindicações "mínimas": desmistificação da democracia racial brasileira; organização política da população negra; transformação do Movimento Negro em movimento de massas; formação de um amplo leque de alianças na luta contra o racismo e a exploração do trabalhador; organização para enfrentar a violência policial; organização nos sindicatos e partidos políticos; luta pela introdução da História da África e do Negro no Brasil nos currículos escolares, bem como a busca pelo apoio internacional contra o racismo no país.

Em todo caso, a atuação do movimento negro organizado foi de fundamental importância para a previsão constitucional do direito das comunidades tradicionais quilombolas em ter suas terras tituladas. Silva (1997, p. 13), ao relembrar a atuação desses grupos durante a constituinte de 1987 e 1988, aponta que

O movimento negro foi à ação para intervir no espaço de criação de novos direitos. Um fato inegável sob o ponto de vista teórico e prático, é que o Estado, a Política e o Direito são espaços de luta, nos quais contingências informam a superioridade de forças que são momentaneamente hegemônicas. Cada grupo de pressão, enfim, levou como resultado concreto o que suas energias e poder de mobilização representaram.

Outro ponto que deve ser ressaltado é que o Brasil se tornou signatário, a partir da Aprovação pelo Decreto Legislativo n 20 de 1965 e do Decreto no 58.824 de 1966 da Convenção 107 da Organização Internacional do Trabalho Sobre 
Populações Indígenas e Tribais de 1957. Dentre os Princípios Gerais da Convenção

107 de 1957, foi estipulado que

A presente Convenção se aplica: a) aos membros das populações
tribais ou semitribais em países independentes, cujas condições
sociais e econômicas correspondem a um estágio menos adiantado
que o atingido pelos outros setores da comunidade nacional e que
sejam regidas, total ou parcialmente, por costumes e tradições
que Ihes sejam peculiares por uma legislação especial; b) aos
membros das populações tribais ou semitribais de países
independentes que sejam consideradas como indígenas pelo fato
de descenderem das populações que habitavam o país, ou
uma região geográfica a que pertença tal país, na época da
conquista ou da colonização e que, qualquer que seja seu
estatuto jurídico, levem uma vida mais conforme às instituições
sociais, econômicas e culturais daquela época do que às
instituições peculiares à nação a que pertencem.

A Parte II da Convenção 107 de 1957 é dedicada ao tema "Terras", momento em que estabelece que

Artigo 11- O direito de propriedade, coletivo ou individual, será reconhecido aos membros das populações interessadas sobre as terras que ocupem tradicionalmente. Artigo $12-1$. As populações interessadas não deverão ser deslocadas de seus territórios habituais sem seu livre consentimento, a não ser de conformidade com a legislação nacional, por motivos que visem à segurança nacional, no interesse do desenvolvimento econômico do país ou no interesse da saúde de tais populações. 2. Quando, em tais casos, se impuser um deslocamento a título excepcional, os interessados receberão terras de qualidade ao menos igual à das que ocupavam anteriormente e que lhes permitam satisfazer suas necessidades atuais e assegurar seu desenvolvimento futuro. Quando houver possibilidade de encontrar outra ocupação ou os interessados preferirem receber uma indenização em espécie ou em dinheiro, serão assim indenizados com as devidas garantias. 3. As pessoas assim deslocadas deverão ser integralmente indenizadas por toda perda ou dano por elas sofrido em consequência de tal deslocamento. Artigo $13-1$. As modalidades de transmissão dos direitos de propriedade e de disposição das terras, consagradas pelos costumes das populações interessadas, serão respeitadas no quadro da legislação nacional, na medida em que atendam às necessidades de tais populações e não prejudiquem seu desenvolvimento econômico e social. 2. Serão tomadas medidas para evitar que pessoas estranhas a essas populações possam prevalecer-se de seus costumes ou da ignorância dos interessados 
em relação à lei com o objetivo de adquirir a propriedade ou o uso de terras pertencentes a essas populações. Artigo 14 - Programas agrários nacionais deverão garantir às populações interessadas condições equivalentes às que se beneficiam dos demais setores da comunidade nacional, no que respeita: a) à concessão de terras suplementares quando as terras de tais populações disponham sejam insuficientes para lhes assegurarem os elementos de uma existência normal ou para fazer face a seu crescimento demográfico; b) à concessão dos meios necessários ao aproveitamento das terras já possuídas por tais populações.

Ao tratar sobre a importância da Convenção 107 de 1957 e seu impacto nos países independentes, a própria OIT (2011, p. 06) assevera que

Embora tenha representado uma primeira tentativa de se codificar, em um instrumento legal de âmbito internacional, os direitos fundamentais desses povos, graves problemas persistiram, inclusive em ex-colônias que haviam se tornado independentes, principalmente em decorrência do tratamento diferente que recebiam em relação ao dispensado aos demais segmentos da população nacional.

Segundo texto publicado pelo Observatório Quilombola (2007), em seu sítio eletrônico, a elaboração da Convenção 107 de 1957 é fruto da influência de

(...) órgãos vinculados à Organização das Nações Unidas - criada em 1945 -, que executaram programas de desenvolvimento na América Andina entre 1952 e 1972. Esta Convenção foi ratificada por 18 países e renunciada por nove que vieram a aderir à Convenção 169. A Convenção 107 tinha como eixo a orientação de que povos indígenas e tribais viriam a integrar as sociedades nacionais majoritárias.

Ainda segundo OIT (2011, p. 06), sob influência da revolução social e cultural dos anos de 1960 e 1970, os povos indígenas e tribais também despertaram para suas origens étnicas e culturais, e consequentemente, para seu direito de serem diferentes sem deixarem de serem iguais. 
Conscientes de sua importância e sob a orientação de sólidas organizações de promoção de seus interesses e proteção de seus direitos, esses povos passaram a assumir, eles próprios, o direito de reivindicar, acima de tudo, sua identidade étnica, cultural, econômica e social, rejeitando, inclusive, serem chamados de "populações". A própria Convenção $n^{\circ} 107$, até então considerada um marco histórico no processo de emancipação social dos povos indígenas, passou a ser criticada por suas tendências integracionistas e paternalistas, fato admitido pelo próprio Comitê de Peritos que, em 1986, considerou-a obsoleta e sua aplicação inconveniente no mundo moderno. (OIT, 2011, p. 06)

Não obstante, o Observatório Quilombola sustenta que essas proposições foram alvos de resistências, sobretudo devido ao fato de não respeitarem a diversidade cultural, o que forçou a OIT a rever a Convenção 107. Em 1986, uma equipe de especialistas iniciou a revisão e seu conteúdo foi debatido na Conferência Internacional do Trabalho em 1988 e 1989.

As novas diretrizes apontavam para o reconhecimento da longa duração e permanência do modo de vida dos povos indígenas e tribais. Orientava para o respeito à diversidade de sua organização social e cultura frente às relações de trabalho tanto antes, como durante e depois da execução de projetos de desenvolvimento. Assim entrou em vigor internacional a Convenção 169. Ela garante que os povos tenham direito ao desenvolvimento a partir de suas próprias prioridades (...). Dados de julho de 2007 confirmam que até o momento 18 países a ratificaram. A Convenção 107 de 1957, ainda vigora em nove países.

Dentre as principais inovações da Convenção 169, OIT (2011, p. 08) aponta os critérios subjetivos da autoidentidade indígena ou tribal, ou seja, nenhum Estado ou grupo social tem o direito de negar a identidade a um povo indígena ou tribal que como tal ele próprio se reconheça. Outra inovação se dá pela distinção entre os termos "populações" e "povos" (limitada exclusivamente aos âmbitos das competências da OIT), onde o primeiro denota transitoriedade e contigencialidade, e o segundo caracteriza segmentos nacionais com identidade e organização próprias, cosmovisão específica e relação especial com a terra em que habitam. 
Apesar de acreditarmos que a Convenção 107 possa ter sido uma das referências para a inserção do direito de regularização das terras quilombolas no texto constitucional de 1988 (Artigo 68 dos ADCT), não foram encontrados elementos na literatura científica que nos permita confirmar essa hipótese. Outra hipótese, a ser verificada, pauta-se na possibilidade de as tratativas para a Convenção 169 terem servido, mesmo que de forma indireta, de embrião de algumas ideias que vieram a materializar-se no texto constitucional de 1988.

Em todo caso, inspirados ou não pela Convenção 107 ou pelas tratativas do texto que veio a se tornar a Convenção 169, Jorge (2015, p. 144) destaca que, no rol de suas pesquisas, a primeira referência à necessidade de atendimento dos direitos fundiários das comunidades quilombolas que foi possível encontrar trata de um trecho da Convenção Nacional do Negro de 1986, que teria servido de onde se lê, no capítulo IX - Sobre a questão da terra:

1 - Será assegurada às populações pobres o direito à propriedade do solo urbano, devendo o Estado implementar as condições básicas de infraestrutura em atendimento às necessidades do homem. 2 Será garantido o título de propriedade das terras às comunidades negras remanescentes de quilombos, quer no meio urbano ou rural. 3 - Que o bem imóvel improdutivo não seja transmissível por herança. Que o Estado promova a devida desapropriação.

A pesquisadora sustenta ainda que esse documento foi de fundamental importância para o processo que desencadeou no Artigo 68 do ADTC, revelando que:

(...) trazia demandas já apresentadas por levantamentos e estudos que vinham sendo feitos durante a década de 1980, tanto no estado do Maranhão (através do Centro de Cultura Negra com o Projeto Vida de Negro, onde ativistas teriam começado a pesquisar e contabilizar as formas de uso e posse da terra, manifestações culturais e religiosas de comunidades negras rurais), quanto no estado do Pará. (JORGE, 2015, p. 144-5)

No âmbito da nossa pesquisa, a primeira manifestação literal e direta pelas demandas de regularização das terras das comunidades negras tradicionais foi 
identificada na obra O Quilombismo, de Abdias do Nascimento, cuja publicação se deu em 1980:

\begin{abstract}
Nosso Brasil é tão vasto, ainda tão desconhecido e despovoado que podemos supor, sem grande margem de erro, que existem muitas comunidades negras vivendo isoladas, sem ligação ostensiva com as pequenas cidades e vilas do interior do país. Serão diminutas localidades rurais, desligadas do fluxo principal da vida do país, e mantendo estilos e hábitos de vida africana, ou quase, sob um regime de agricultura coletiva de subsistência ou sobrevivência. Podem até mesmo usar o idioma original trazido da África, estropiado, é bem verdade, porém mesmo assim linguagem africana conservada na espécie de quilombismo em que vivem. Às vezes podem até ganhar notícias extensas nas páginas da imprensa, conforme ocorreu à comunidade do Cafundó, situada nas imediações de Salto de Pirapora, no Estado de São Paulo. Os membros da comunidade herdaram uma fazenda deixada pelo antigo senhor, e não faz muito tempo as terras estavam sendo invadidas por latifundiários das vizinhanças. Obviamente brancos, esses latifundiários, com mentalidade escravocrata, não podem aceitar que um grupo de descendentes africanos possua uma propriedade imobiliária. Este não é um fato único, mas foi aquele que ganhou maior publicidade, mobilizando os negros paulistas em sua defesa. Ao visitar pela primeira vez a cidade de Conceição de Mato Dentro, em Minas Gerais, em 1975, tive oportunidade de me encontrar com um dos moradores de uma comunidade negra daquelas redondezas semelhante a Cafundó. Também herdaram a propriedade, segundo me relatou o dito morador, negro de 104 anos, ágil de inteligência e de pernas. Caminhava quase todos os dias cerca de 10 quilômetros a pé, e assim mantinha o contato do seu povo com a cidadezinha de Mato Dentro. O avanço de latifundiários e de especuladores de imóveis nas terras da gente está pedindo uma investigação ampla e funda. Este é um fenômeno que ocorre tanto nas zonas rurais como nas cidades.
\end{abstract}

Nessa mesma obra, relata também a perda de terras dos centros de Candomblé em Salvador - BA, denunciando que

(...) pelo menos nos últimos vinte anos, o cerco movido pela policia foi sensivelmente fortalecido por um poderoso aliado - a expansão imobiliária, que se estendeu às áreas distantes do centro da cidade onde ressoavam 06 atabaques. Mais ainda, em nenhum momento a Prefeitura esboçou barricadas legais para proteger esses redutos da cultura afro-brasileira - embora a capital baiana arrecadasse gordas divisas com a exploração do turismo fomentada pela magia dos orixás. (...) E nunca se soube da aplicação de sanções para os inescrupulosos proprietários de terrenos vizinhos às casas de culto, que se apossam impunemente de áreas dos terreiros. Foi assim que, em poucos anos, a Sociedade Beneficente São Jorge do Engenho 
Velho, ou terreiro da Casa Branca, acabou perdendo metade de sua antiga área de 7.500 metros quadrados.

Abdias do Nascimento ainda conclui ao refletir sobre as mazelas enfrentadas pelos negros no que tange à defesa de suas terras, afirmando que

Eis como a sociedade dominante apertou o cerco da destituição, da fome e do genocídio dos descendentes africanos. Até os poucos, as raras exceções que por um milagre conseguiram ultrapassar a fronteira implacável da miséria ou as instituições religiosas que ocupavam há séculos determinado espaço, se vêm de uma hora para outra invadidas em suas propriedades e usurpados em suas terras!

Giacomini (2009, p.03), por sua vez, constata que os quilombolas começaram a se organizar durante os anos 80 para garantir seu direito memorial à propriedade das terras que ocupam. Declara ainda que:

As lutas pelas terras de quilombos juntamente com as lutas dos movimentos negros urbanos pressionaram o trabalho da Constituinte de 1988, aprovando o Artigo 68 que garante o direito a esses grupos afrodescendentes que estejam morando em suas terras à propriedade definitiva atribuídos por um passado de luta e resistência. Essas conquistas apoiadas na Constituição Federal se tornam possíveis através da reconstrução histórica e cultural desses grupos étnicos. (GIACOMINI, 2009, p.03).

Giacomini (2009) sustenta ainda que o longo processo reivindicatório culminou no reconhecimento dos direitos das comunidades, caracterizadas como remanescentes de quilombos. Nesse sentido, a autora é categórica ao assumir que

(...) o primeiro resultado concreto apareceu no texto constitucional de 1988, por meio do Artigo 68 do Ato das Disposições Constitucionais Transitórias. E dos Artigos 215 e 216 de nossa Carta Magna que aponta diretrizes para a proteção do patrimônio e das manifestações culturais dos diferentes segmentos étnicos nacionais. (GIACOMINI, 2009, p.03) 


\section{4 - A titulação dos territórios quilombolas: um direito constitucional}

A previsão constitucional do direito das comunidades remanescentes de quilombos terem suas terras tradicionais reconhecidas e tituladas pelo Estado Brasileiro é, sem dúvidas, o marco fundamental para a garantia dos direitos étnicos territoriais das comunidades afrodescendentes no Brasil, uma vez que, a partir desse momento, o Estado estaria obrigado a cumprir com seu papel constitucional de executar políticas públicas que fornecessem a segurança fundiária e jurídica a essas comunidades historicamente relegadas pelo poder público nacional.

Arruti (2009) sustenta, porém, que o Artigo 68 do Ato das Disposições Constitucionais Transitórias (ADCT) se fez como parte integrante das comemorações do Centenário da Abolição da Escravatura, que se deu em 1988. Treccani (2006) reconhece a importância do desse Artigo constitucional ao apontar que

Apesar da abolição formal da escravidão decretada pela Lei Áurea (Lei $n^{\circ} 3.353$, de 13 de maio de 1888), passaram-se outros cem anos para que a Constituição Federal (Art. 68 do Ato das Disposições Constitucionais Transitórias - ADCT, da Constituição Federal de 1988), devolvesse aos descendentes dos antigos quilombos a propriedade dos territórios que lhes vai permitir o acesso à cidadania plena.

Para Fiabani (2008), o Artigo 68 do Ato das Disposições Constitucionais Transitórias apresenta um histórico de construção bastante conturbado, confuso e, até certo ponto, surpreendente:

A princípio, o artigo não teria se originado de emenda popular como citamos anteriormente. No entanto, ressaltamos que, na época da Constituinte, havia um movimento organizado no Maranhão e no Pará envolvendo as comunidades negras rurais. Inclusive, há documentos que atestam a preocupação dos camponeses e das lideranças em relação à Constituinte e à questão agrária. Resta saber se a reivindicação pela regularização das terras ocupadas pelas comunidades partiu do movimento do Maranhão e do Pará ou não. (...) Depois do "I Encontro de Comunidades Negras Rurais do Maranhão", no mesmo ano, o Centro de Cultura Negra do Maranhão 
e o Centro de Estudos e Defesa do Negro do Pará participaram da "I Convenção Nacional do Negro pela Constituinte", realizado em Brasília, convocada pelo o Movimento Negro Unificado. Deste evento saiu uma proposta de norma que garantisse os direitos das comunidades negras rurais. A proposta foi encaminhada à deputada federal Benedita da Silva, que apresentou ao Congresso Nacional Constituinte. Esta é a versão defendida pelo Centro de Cultura Negra do Maranhão, quanto ao surgimento do artigo 68 do ADCT: teria nascido nas discussões da base, em um evento que reuniu lideranças das comunidades negras, sendo encaminhada proposta à deputada Benedita da Silva que, por sua vez, conduziu-a à Assembleia Nacional Constituinte. (FIABANI, 2008, p.133-134)

Por outro lado, analisando os registros dos procedimentos observados no seio do processo formal da Constituinte, Fiabani (2008, p.135) identificou 08 audiências da Subcomissão dos Negros, Populações Indígenas, Pessoas Deficientes e Minorias, onde participaram antropólogos, lideranças do movimento negro, sociólogos, professores, historiadores, além dos deputados constituintes, mas em nenhuma delas a questão fundiária das terras quilombolas foi mencionada. Foi apenas na fase da proposição dos anteprojetos, que surge a menção à questão das terras quilombolas, já com o texto que dava mostras no que se transformaria 0 atual artigo 68, com os seguintes dizeres: "O Estado garantirá o título de propriedade definitiva das terras ocupadas pelas comunidades negras remanescentes de quilombos".

Durante a Assembleia Nacional Constituinte, Olympio Serra foi assessor da Comissão de Índios, Negros e Minorias. O antropólogo e historiador José Maurício Arruti obteve informações junto ao assessor Serra e descobriu que o artigo 68 teria sido algo improvisado, "sem uma proposta original clara ou maiores discussões posteriores, ainda que seja evidente a sua inspiração histórica e arqueológica e o desconhecimento de „problema social' implicado no tema”. (FIABANI, 2008, p.137)

Fiabani (2008, p.140) discute ainda os motivos pelos quais a questão da regularização das terras quilombolas foi incluída no Ato das Disposições Constitucionais Transitórias e não ficou no corpo permanente da Carta Magna. Essas razões são controversas, passando pelas correntes que defendem que a 
causa era até então tratada no seio das demandas da Cultura (permanentes) e, uma vez reprovada nesse contexto, configura-se como um dispositivo transitório atípico, vez que só pôde ser aprovado no apagar das luzes dos trabalhos de feitura da nova Constituição. Para Fiabani (2008), essas palavras resumem os argumentos do historiador Dimas Salustiano da Silva, assim como do antropólogo Adolfo Neves de Oliveira Jr e do deputado constituinte José Carlos Saboia. Sobre esse mesmo processo, Silva (1997, p. 12-3) nos relata que

\begin{abstract}
A evolução dos debates constituintes em 1987, que desaguaram no texto normativo de 1988, ora em apreciação, não pode ser considerada das mais interessantes. Preponderou, na análise que pode ser feita do "Diário da Constituinte", um espírito pragmático e regimental nas decisões. É possível que o senso comum imperante entre os congressistas tenha falado mais alto, segundo o qual comunidades negras remanescentes de quilombos remontam ao passado, representam resquícios insignificantes de uma história que deve ser esquecida, são tidas como populações fadadas ao desaparecimento, ou mesmo inexistentes, talvez minúsculas ou em pouca monta. Entrementes, a história da escravidão no Brasil, encarada sob outro aspecto que não o oficial e submetida a uma análise detida da conflituosa realidade fundiária urbana e rural brasileira, autoriza um outro tipo de compreensão do problema.
\end{abstract}

Nesse contexto, ganham relevância os argumentos que se baseiam no desconhecimento dos próprios deputados em relação à dimensão da causa em questão, por acreditarem que se tratava de casos raros e pontuais, como o do Quilombo dos Palmares. Essa é a base da compreensão da antropóloga llka Boaventura Leite, compartilhada por Fiabani (2008, p.141):

A probabilidade de que os deputados constituintes tenham aprovado o dispositivo constitucional certos de que se tratava de quilombos originados de escravos fugidos - e não de comunidades negras rurais em geral - foi confirmada pela Agência Estado, na reportagem publicada em agosto de 2007. Segundo a agência de notícias, „em 1988, quando discutiam e votavam os dispositivos transitórios da futura Constituição, os deputados constituintes não viram problema em incluir um artigo sobre a população remanescente dos antigos quilombos". Segundo a Agência Estado, „do centro à esquerda, do antigo PFL ao PT, todos os partidos concordaram com o artigo 68, que, em duas linhas, obriga o Estado a reconhecer e titular as terras de quilombolas". Para os deputados, tratava-se de ocupantes das 
terras onde houvera antigos quilombos, pois „era citado, entre os deputados um estudo do sociólogo e historiador Clóvis Moura, que mencionava 55 remanescentes de quilombos com existência documentalmente comprovada no Brasil'. Esta hipótese é muito mais do que plausível, pois, até 1988, a historiografia conhecia somente e trabalhava apenas com 0 conceito de quilombo antigo comunidades de cativos fugidos.

Sobre o fato de a questão dos territórios quilombolas terem sido colocadas no ADCT, Treccani (2005) assevera que não secundariza seu valor, pois é fruto do mesmo Poder Constituinte originário como os demais. Esclarece também que a transitoriedade do artigo se justifica pelo fato de que o mesmo perderá sua eficácia assim que o último território quilombola for titulado.

Silva (1997, p.26) conclui sobre a importância da previsão constitucional dos direitos dessas populações à regularização de suas terras, ponderando que

O Artigo 68 do ADCT está distante de ser a melhor resultante produzida pela conjugação de forças dos assessores teóricos, dos trabalhadores práticos e da pujança e combatividade do Movimento Negro. No entanto, é com isso que podemos contar. Trata-se de uma representação daquilo que fomos capazes de reproduzir, ao mesmo tempo que pedagogicamente sinaliza para onde devemos dirigir nossos esforços.

A previsão da titulação das terras quilombolas na Constituição é, sem dúvidas, uma das maiores conquistas dos movimentos étnicos organizados no Brasil. Porém, da forma como se deu essa previsão, várias questões fundamentais de natureza jurídica e principalmente política ficaram indefinidas - ou pelo menos mal delimitadas -, tal como a definição de quem eram os grupos étnicos sociais a que se referia o legislador constitucional.

\section{5 - Os quilombos e os quilombolas: o que eram e o que são?}

O debate, de extrema relevância, no contexto da regularização dos territórios quilombola, passa pela discussão a respeito do significado do termo quilombo e, por 
consequência, dos quilombolas. Esse ponto se destaca, à medida que serviu de fundamento para a aprovação do texto constitucional, e de que sua concepção é pedra angular dos critérios de identificação do objeto das ações de titulação das terras quilombolas. A real compreensão do "espírito da lei", ou seja, do significado que era apreendido pelo legislador, no momento de sua elaboração e aprovação, acaba sendo determinante, adiante, para a eleição dos critérios, princípios e diretrizes de implementação das políticas que são a ela vinculadas, como será discutido oportunamente.

No caso específico dos objetivos propostos por esse estudo, as divergências semânticas entre o conceito tradicional e contemporâneo do termo quilombo (quilombos novos) teriam o potencial de alterar fundamentalmente toda uma sistemática burocrática e legislativa observada nas titulações das terras, o que traria (ou ainda traz) consequências para a gestão social, política e fundiária das ações. Numa caracterização do conceito tradicional dos quilombos, Fiabani (2007, p.02) afirma que

O quilombo podia gerar-se quase naturalmente. Depois de instalado, crescia e tomava consistência à medida que recebia novos indivíduos. Fora casos excepcionais, a ampliação das comunidades quilombolas dava-se, sobretudo por agregação de membros provenientes do seu exterior - nativos, homens livres pobres e, sobretudo, cativos fugidos do campo e das cidades.

Maestri (2002, p.39), justifica a expansão do termo quilombo às comunidades rurais de afrodescendentes que não se originaram desses territórios, por uma questão de "direito social". Leite (2005) apresenta um conceito criado à perspectiva dos próprios quilombolas, apontando que se trata de um sentimento que converge na luta por uma demanda que não busca um passado a ser rememorado, mas um direito a ser reconhecido.

A expressão "quilombos contemporâneos", para se referir a comunidades negras em geral agrupadas em um território, surgiu após 1990. No referido ano, o conceito de quilombo foi ressignificado após longos debates entre os profissionais que tratavam da questão, parlamentares e lideranças das comunidades e do movimento negro. Muitas comunidades incorporaram a identidade quilombola. Parece meridianamente claro que os deputados constituintes acreditavam 
que se tratava de alguns poucos quilombos que foram identificados antes de 1888. (FIABANI, 2008, p.141)

Fiabani (2008) registra que a FCP, no início da década de 1990, assume um entendimento de que quilombos seriam sítios historicamente ocupados por negros que tenham resíduos arqueológicos de sua presença, inclusive as áreas ocupadas ainda hoje por seus descendentes, com conteúdos etnográficos e culturais. Trata-se de uma categorização que se aproxima do conceito difundido nas negociações do Artigo 68 da ADCT. Porém, a ressemantização do termo, que é uma das chaves para o entendimento de toda a questão das políticas de regularização das terras quilombolas, assume uma nova faceta:

(...) ao cruzarmos as informações obtidas através da Agência Estado com as afirmações de Alfredo Wagner de Almeida, José Mauricio Arruti, Rosa Acevedo e Edna Castro, confirma-se a ressemantização do termo quilombo, a partir de 1990. Também, confirma-se que a ressignificação ocorreu por ocasião do envolvimento destes profissionais com as comunidades negras que objetivavam 0 reconhecimento da condição "remanescente de quilombo". Em entrevista cedida ao autor, o antropólogo e historiador Pedro Paulo Funari entende que "a ressignificação é um fenômeno social normal e esperado". Para Funari, "os grupos e indivíduos que descendem, ou pensam descender, de escravos, pobres, imigrantes, indígenas, ressignificam, todo o tempo, as classificações sociais. (FIABANI, 2008, p. 143)

No bojo dessa discussão, Jorge (2015, p.143) propõe que, ao contrário do que comumente se observa nas relações entre Estado versus Movimentos Sociais, em que o Estado atende a uma "vocalização" sobre a agenda pública e lança, a partir dessa demanda, um dispositivo executivo para seu atendimento, o caso das terras quilombolas se deu de forma inversa, pois somente a partir do Artigo 68 do ADCT foi que esses povos passaram a demandar seu reconhecimento como quilombolas e se movimentarem socialmente, para garantirem o atendimento a seus direitos territoriais:

A imensa maioria dos grupos sociais que carregavam resquícios de ancestralidade negra, com historicidade e modo de vida próprio, não 
havia organizado ainda as suas demandas de forma sistemática, antes do dispositivo constitucional de 1988. (JORGE, 2015, p. 144)

Fiabani (2008, p.146) destaca ainda a nova ressemantização instituída pela FCP em 1994, em que o conceito oficial de quilombo adotado pela Fundação passou a ser:

(...) comunidades negras rurais que agrupam descendentes de escravos [que] vivem da cultura de subsistência e onde as manifestações culturais têm forte vínculo com o passado ancestral. Esse vínculo com o passado foi reificado, foi escolhido pelos habitantes como forma de manter a identidade.

A despeito dessa nova ressemantização, Fiabani (2008, p.148) destaca que a Associação Brasileira de Antropologia - ABA institui, em 1995, por meio de um Grupo de Trabalho, uma nova interpretação para o quilombo e também para os remanescentes:

Os remanescentes de quilombos não seriam somente os "grupos isolados ou de uma população estritamente homogênea. Também não seriam aqueles constituídos a partir de uma "referência histórica comum, construída a partir de vivências e valores partilhados. Mas seriam "grupos étnicos conceitualmente definidos pela Antropologia como um tipo organizacional que confere pertencimento através de normas e meios para indicar afiliação ou exclusão".

Fiabani (2014, p.61) atesta em sua fala que a ressignificação do termo foi um processo constituído aos poucos, ação consciente originada, sobretudo de fora das comunidades, com o objetivo estratégico de fundar um conceito que reunisse todas as matrizes formadoras de comunidades camponesas rurais negras, caboclas, mestiças, originadas ou não de quilombos. O autor é taxativo ao concluir que

A ressignificação do termo quilombo destruiu a história objetiva e abriu espaço para a invenção do passado e da tradição. O passado e a tradição passam a ser controlados, definidos e inventados segundo a vontade de determinados grupos, conscientes das suas intenções. Mesmo que a ressignificação tenha oportunizado a um número maior de comunidades reivindicarem o direito à titulação das terras, o ato 
representou a destruição da própria história da maioria das comunidades que não surgiram a partir do quilombo. Caso não seja resguardado o caráter político-ideológico dessa atribuição, as comunidades foram induzidas a romper os laços com suas próprias raízes históricas objetivas. (FIABANI, 2014, p.61)

Por outro lado, Treccani (2005), apresenta um entendimento divergente, ao avaliar que

Não se pode mais aceitar a falsa ideia de que as normas constitucionais tenham um conteúdo meramente programático, como pretendiam os juristas da escola positivista ou os liberais; elas são cogentes, isto é, determinam que o Poder Público e todos os cidadãos se engajem nesta missão transformadora, passando seus ditames da esfera abstrata dos princípios filosóficos para a prática política cotidiana. Isso só poderá ser alcançado na medida em que se conseguir erradicar a pobreza e a marginalização e reduzir as desigualdades sociais e regionais, promovendo o bem de todos, sem preconceitos de origem, raça, sexo, cor, idade e quaisquer outras formas de discriminação. É nesta perspectiva que devem interpretarse o reconhecimento do direito à terra e a garantia da manutenção de sua cultura própria para as comunidades quilombolas. A garantia de segurança jurídica alcançada com 0 reconhecimento de seu território é a base para a concretização dos demais direitos fundamentais. (TRECCANI, 2005)

O sítio eletrônico da Coordenação Nacional de Articulação das Comunidades Negras Rurais (CONAQ) aborda a questão, apontando que:

O Conceito de Quilombo ganha novo marco jurídico após a Constituição de 1988 e esse fato é determinante para a garantia do direito à terra a essas comunidades. É também um fator fundamental para o estabelecimento e organização do movimento quilombola em nível nacional, que, a partir da construção de sua identidade étnica reivindica o seu direito à terra.

Como pode ser constatado na fala de Fiabani (2014) e confirmada, mesmo que implicitamente pela fala de Treccani (2005) e CONAQ, a ressemantização do termo quilombo, como uma estratégia, para ampliar a gama de famílias passíveis de atendimento de suas demandas por regularização de terras, assumindo-se não mais 
como camponeses afrodescendentes, mas agora como remanescentes de quilombo, traz consigo impactos de natureza política e administrativa que não se fizeram presentes no contexto constituinte, conforme discutido anteriormente. Em tempo, reafirmo que essa estratégia representa um impacto sensível no contingente populacional e territorial, a ser atingido pelo planejamento das ações de execução dessas ações por parte do Poder Público.

Arruti (2003) pondera que, mesmo no âmbito dos movimentos negros brasileiros, o termo quilombo só havia sido introduzido

(...) como uma espécie de acervo simbólico para suas lutas urbanas, sem maiores consequências sobre sua histórica falta de atenção ao mundo rural, como para o Estado Brasileiro a questão negra sempre foi isolada como uma questão cultural, esvaziada de seus significados políticos, isso colocou tais comunidades negras rurais em situação curiosa. Elas são apoiadas e assessoradas por entidades do movimento social originalmente ligadas às lutas indígenas, da mesma forma que os recursos administrativos acionados pelo Estado têm forte inspiração no indigenismo oficial. Ocorre então a transmissão de uma experiência histórica da luta por territórios étnicos das comunidades indígenas para comunidades negras. (Arruti, 2003. p.14)

O autor denuncia ainda que a falta de critérios da FCP, para certificar as comunidades quilombolas, acarreta o uso indevido das políticas, com vistas à atração de recursos para o caixa dos municípios, além do estímulo à criação de associações nessas comunidades sem nexo efetivo com as demandas históricas da pauta quilombola.

(...) já são numerosos os casos conhecidos de comunidades que são "certificadas" pela Fundação Cultural Palmares (FCP) por demanda das suas prefeituras, mas sem que a própria comunidade saiba de tal certificação ou do que ela representa, em qualquer sentido, muito menos orçamentário. Isso faz com que a observação dos números sobre os quais falávamos no início deste artigo, ganhe um sentido absolutamente distinto. A multiplicação dos quilombos está, em muitos municípios, servindo a uma nova forma de exploracão destas comunidades, agora por meio do dinheiro público que lhes é destinado e do qual elas não usufruem na forma de políticas públicas. Além disso, tal exploração está associada a pelo menos outros dois efeitos perversos. De um lado, ela tem implicado na criação de associações comunitárias de cima para baixo, totalmente descoladas da noção de representação comunitária e tuteladas pelos 
interesses políticos locais assentados nas municipalidades. De outro lado, esse processo gera uma importante distorção na representação pública destas comunidades, quando aponta para um crescimento acentuado e acelerado das suas bases, sem que ele contribua efetivamente para consolidação de um movimento regional e nacional quilombola. (ARRUTI, 2006, p.108). Grifo nosso.

\section{6 - Controvérsias quanto a delimitação das terras quilombolas e as possibilidades de desapropriação}

Outro ponto de divergência estabelecido a partir das diversas interpretações do Art. 68 do ADCT diz respeito ao que se compreende como os critérios a serem adotados pelo Poder Público (INCRA) na identificação e delimitação das terras a serem tituladas em favor das comunidades quilombolas.

Ocorre que o Art. 68 do ADCT não estabelece, de forma explícita, os parâmetros para que se defina os limites do território a ser objeto da titulação. Tal definição se dá apenas de forma indireta, no momento em que o legislador estabeleceu que "aos remanescentes das comunidades de quilombos que estejam ocupando suas terras é reconhecida a propriedade definitiva". Constato, nesse contexto, que as terras objeto de regularização por meio do citado dispositivo constitucional devem ser aquelas que estavam sendo ocupadas pelos remanescentes de quilombo na data da promulgação do texto constitucional (05 de outubro de 1988). Nesse ponto, corroboro com as alegações do Partido da Frente Liberal (PFL), atualmente denominado DEMOCRATAS, que constituem uma das alegações da ADI-3239:

Ante o enunciado constante no Art. 68 do ADCT, descabe ao Poder Público desapropriar a área, visto que a propriedade decorre diretamente da Constituição. Nos termos da dicção constitucional, é reconhecida a propriedade definitiva. Ou seja, não há que se falar em propriedade alheia a ser desapropriada para ser transferida aos remanescentes de quilombos, muito menos em promover despesas públicas para fazer frente a futuras indenizações. As terras são, desde logo, por força da Lei Maior, dos remanescentes das comunidades quilombolas que lá fixam residência desde 05 de outubro de 1988. O papel do Estado limita-se, segundo o art. 68 do ADCT, a meramente emitir os respectivos títulos. (ADI-3239, p. 06). 
Discordo, contudo, da tese defendida pela ADI-3239 de que não há que se falar em propriedade alheia a ser desapropriada para ser transferida aos remanescentes de quilombo, pois compreendo que, nos casos em que por força de comprovado crime de esbulho ou espoliação, com sentença judicial transitada em julgado, há necessidade de o Estado promover a retomada da área para destinação à comunidade quilombola, independentemente se o referido crime ocorreu antes ou depois da promulgação da Constituição.

Entretanto, não haveria objeções, em meu entendimento, que outras áreas reivindicadas pela comunidade que não se enquadrem nos temos anteriormente definidos sejam obtidas pelo INCRA para destinação às comunidades. Contudo, tal destinação não se daria por força do Art. 68 do ADCT e sim, de outros dispositivos.

O primeiro é o Art. 216 da Constituição de 1988, (especialmente nos $\S 1^{\circ}$ e $5^{\circ}$ que tratam, respectivamente, da proteção do patrimônio cultural brasileiro por meio de tombamento e desapropriação; do tombamento de todos os documentos e os sítios detentores de reminiscências históricas dos antigos quilombos). Nos termos deste dispositivo, compreendo que o processo de desapropriação teria como objeto as porções do território pleiteado caracterizadas por elementos que fundamentam a preservação da identidade cultural e memória coletiva e que guardem relação direta e função indispensável às suas crenças e valores. São exemplos as áreas de valor simbólico, onde estão localizados os antigos cemitérios, templos religiosos, abrigos, refúgios etc. que, por motivos diversos, não estão localizadas nas "terras ocupadas pela comunidade". Constato, portanto, que o Art. 216 da Constituição Federal não é instrumento legítimo para que se promova a desapropriação por motivação fundamentada na sustentabilidade econômica da comunidade, tais como a ampliação das áreas para plantio, criação de animais, extração vegetal, pesca etc., tal como se observa atualmente na instrução dos procedimentos do INCRA. Para esses casos, em que a soma da área ocupada e objeto de esbulho não seja suficiente para garantir a sustentabilidade econômica e ambiental da comunidade e de suas gerações futuras, compreendo que o procedimento deveria ser fundamentado nas prerrogativas do Estado promover desapropriação por interesse social restrita aos casos em que se verifique a ocorrência de propriedades na região do território pleiteado que não cumpram a função social (nos termos da redação dada pela Lei no 8.629 de 25 de fevereiro de 1993) ou cujos proprietários a 
negociação do imóvel por meio de processo de compra e venda (nos termos do Decreto 433 de 24 de janeiro de 1992).

Este posicionamento ganha relevância à medida que considera como fundamento básico o fato de que o Decreto 4.887 de novembro de 2003 se restringir exclusivamente à regulamentação do Art. 68 do ADCT. Portanto, as áreas pleiteadas pelas comunidades tradicionais que não estejam em sua posse ou que não foram objeto de esbulho, teriam necessariamente que ser obtidas por instrumento diverso ao referido Decreto. Nesse sentido, essas áreas obtidas fora do que é amparado pelo Art. 68 do ADCT e por consequência do Decreto 4.887 de novembro de 2003 seriam incorporadas ao título do território quilombola apenas se esta for a vontade manifesta da própria comunidade. Caso esta não seja a decisão da comunidade, compreendo que estas terras deveriam ser repassadas aos quilombolas sob outras modalidades de destinação que porventura atendam melhor seus interesses, como por exemplo, por meio da criação de projetos de assentamento, reserva agroextrativista, etc. Este posicionamento encontra subsídio, inclusive, na própria Convenção 169 da OIT, que é clara ao instituir que:

Ao aplicarem as disposições desta parte da Convenção, os governos deverão respeitar a importância especial que para as culturas e valores espirituais dos povos interessados possui a sua relação com as terras ou territórios, ou com ambos, segundo os casos, que eles ocupam ou utilizam de alguma maneira e, particularmente, os aspectos coletivos dessa relação. (OIT-CONVENÇÃO 169, p. 05)

É evidente que, ao vincular obrigatoriamente a titulação das terras quilombolas sob a cláusula da coletividade do domínio, o Decreto 4.887 de novembro de 2003 transforma a possibilidade de titulação coletiva em regra, tornando essa a única opção das comunidades. Não respeita, portanto, as situações particulares que existem nas mais diferentes comunidades tradicionais que, por motivos diversos, inclusive de natureza íntima, não admitem a titulação de suas terras de maneira coletiva. É o motivo pelo qual, no Estado do Amapá, as comunidades de Carvão e Mazagão Velho terem solicitado o encerramento do processo de regularização de seus territórios.

A observação dessas especificidades possibilitaria, em meu entendimento, o destravamento de boa parte dos processos de regularização das terras quilombolas 
e contribuiria para a melhoria da qualidade de vida das comunidades tradicionais, da sustentabilidade econômica e ambiental de suas atividades, da segurança jurídica de suas ocupações e, o que considero mais importante, garantiria o direito da própria comunidade decidir sobre a forma de destinação que melhor lhe atenda, evitando assim a excessiva tutela do estado na tomada de decisões na condução do processo, fato que as obriga a se submeter, por exemplo, às clausulas de coletividade e pró-indivisibilidade da área do título outorgado, mesmo que essa não seja a sua vontade, mas é, equivocadamente, a única alternativa que lhe é dada pelo INCRA.

Contudo, existem outros desdobramentos desse posicionamento para a condução do processo de titulação das terras quilombolas. Trata-se da consideração de que, nos termos da desapropriação por interesse social para a reforma agrária, são insuscetíveis a pequena propriedade (imóvel composto por área de 01 a 04 módulos fiscais) e a média propriedade rural (imóvel composto por área superior a 04 até 15 módulos fiscais), desde que o seu proprietário não possua outra propriedade rural. Significa, portanto, que imóveis até 15 módulos fiscais ${ }^{3}$ e cujo proprietário não tenha outro imóvel rural estariam imunes ao alcance da legislação para regularização de terras quilombolas por desapropriação, restando, contudo a alternativa da negociação para compra e venda. Esse entendimento minimizaria, portanto, os impactos e custos sociais ocasionados pelas ações de desintrusão de pequenos agricultores familiares (ou camponeses) que adquiriram suas propriedades de boa fé e a exploram de forma mansa e pacífica. Reitero, nesse momento, que não se trata de reduzir os direitos das comunidades quilombolas a terem suas terras regularizadas, mas de resguardar a aplicação da norma constitucional nos limites de sua competência e minimizar o risco de que ações desempenhadas pela autarquia acabem gerando tensões e conflitos entre setores da sociedade que sofreram historicamente com a omissão e ineficiência do Estado

\footnotetext{
${ }^{3}$ Segundo informa o sítio eletrônico da Embrapa (www.embrapa.br) e do INCRA (www.incra.gov.br) o módulo fiscal é uma unidade de medida, em hectares, cujo valor é fixado pelo INCRA para cada município levando-se em conta: (a) o tipo de exploração predominante no município (hortifrutigranjeira, cultura permanente, cultura temporária, pecuária ou florestal); (b) a renda obtida no tipo de exploração predominante; (c) outras explorações existentes no município que, embora não predominantes, sejam expressivas em função da renda ou da área utilizada; (d) o conceito de "propriedade familiar". A dimensão de um módulo fiscal varia de acordo com o município onde está localizada a propriedade. $O$ valor do módulo fiscal no Brasil varia de 5 a 110 hectares. Esta medida é essencial para a classificação dos imóveis rurais entre: minifúndios: propriedades com área de até 1 módulo fiscal; pequena propriedade: entre 1 e quatro módulos fiscais; média propriedade: superior a quatro e até 15 módulos fiscais; grande propriedade: superior a 15 módulos fiscais.
} 
brasileiro, como os quilombolas e os pequenos agricultores familiares.

Há que se ressaltar que algumas Constituições Estaduais também se inspiraram no Artigo 68 dos ADCT e incluíram em seus textos artigos cujo objeto é a titulação das terras quilombolas. Treccani (2005) aponta que

Depois da vitória em nível federal, o movimento negro organizou-se também para influenciar nas constituições estaduais. Como resultado deste esforço também as constituições dos estados Bahia (art. 51 ADCT), Goiás (art. 16 ADCT), Maranhão (art. 229), Mato Grosso (Artigo 33 ADCT) e Pará (art. 322) reconhecem o direito dos remanescentes dos quilombos à propriedade de suas terras.

Treccani (2005) organizou uma tabela em que são condensadas as informações referentes aos atos constitucionais desses Estados, comprovando a forte relação entre o teor desses dispositivos com o da Constituição Federal de 1988:

\begin{tabular}{|c|c|c|c|c|}
\hline Bahia & Goiás & Maranhão & Mato Grosso & Pará \\
\hline Art. 51 ADCT & Art.16 ADCT & Art. 229 & Art. 33 ADCT & Art. 332 \\
\hline \begin{tabular}{|l} 
O Estado \\
executará, no \\
prazo de um \\
ano após a \\
promulgação \\
Desta \\
Constituição, \\
a identificação, \\
discriminação \\
e titulação das \\
suas terras \\
ocupadas \\
pelos \\
remanescentes \\
das \\
comunidades \\
dos \\
quilombos
\end{tabular} & \begin{tabular}{|l} 
Aos \\
remanescentes \\
das \\
comunidades \\
dos quilombos \\
que estejam \\
ocupando \\
suas terras, é \\
reconhecida a \\
propriedade \\
definitiva, \\
devendo o \\
Estado emitir- \\
Ihes os \\
respectivos \\
títulos.
\end{tabular} & \begin{tabular}{|l} 
O Estado \\
reconhecerá e \\
legalizará, na \\
forma da lei, \\
as terras \\
ocupadas por \\
remanescentes \\
das \\
comunidades \\
dos quilombos.
\end{tabular} & \begin{tabular}{|l|} 
O Estado \\
emitirá, no \\
prazo de um \\
ano, \\
independente \\
mente de estar \\
amparado em \\
legislação \\
complementar, \\
os títulos de \\
terra aos \\
remanescentes \\
de quilombos \\
que ocupem as \\
terras há mais \\
de 50 anos.
\end{tabular} & \begin{tabular}{|l} 
Aos \\
remanescentes \\
das \\
comunidades \\
dos quilombos \\
que estejam \\
ocupando \\
suas terras, é \\
reconhecida a \\
propriedade \\
definitiva, \\
devendo o \\
Estado emitir- \\
lhes títulos \\
respectivos no \\
prazo de um \\
ano, após \\
promulgada \\
esta \\
Constituição.
\end{tabular} \\
\hline
\end{tabular}

Tabela 01: Territórios Quilombolas nas Constituições Estaduais. Fonte: TRECCANI (2005). 
A Comissão Pró-Índio de São Paulo - CPI/SP, em levantamento mais atual (julho de 2015), estabelece que

\begin{abstract}
Mesmo estados que não contam com tal dispositivo em suas constituições, reconhecem às comunidades remanescentes de quilombolas o direito à terra em legislação infraconstitucional e/ou buscam garantir a sua efetividade por meio de políticas ou programas para regularização das terras. É o que ocorre em 10 estados: Amapá, Bahia, Espírito Santo, Maranhão, Pará, Paraíba, Piauí, Rio Grande do Norte, Rio Grande do Sul, e São Paulo.
\end{abstract}

Apesar de representarem um importante elemento para a compreensão e análise das ações de regularização das terras quilombolas, optamos por não abordar diretamente as legislações e a implementação dessas políticas nos âmbitos estaduais, prevalecendo o foco sobre a atuação do Governo Federal. Exceção será concedida, apenas, em situações em que o Governo Federal realiza parcerias/convênios com os Estados, para implementação dessas ações.

Todavia, o sentimento de decepção, com os resultados alcançados pelas ações de titulação de terras quilombolas, parece ser geral nos discursos dos representantes dessas comunidades. Na fala do Dr. Daniel Sarmento - Procurador Regional da República e integrante do Grupo de Trabalho Quilombos da 6ª Câmara de Conciliação e Revisão do Ministério Público Federal, contida na ATA DA AUDIÊNCIA PÚBLICA SOBRE A AÇÃO DO MPF NA DEFESA DAS COMUNIDADES QUILOMBOLAS, de 2013, estão presentes vários aspectos que resumem esse sentimento de frustração:

(...) desde 1988 existe um art. 68 do ADCT prevendo a destinação dos territórios tradicionais aos quilombolas e ao longo desses 25 anos e quase nada aconteceu. Existe um déficit muito grande de cumprimento desse como de outros direitos fundamentais conferidos a esses povos. Caracteriza o racismo institucional, que não é apenas de homens e mulheres que usam palavras feias para desqualificar pessoas e grupos, mas de instituições que negam direitos e utilizamse de suas estruturas burocráticas para impedir sua implementação.

Fiabani (2014, p.62) destaca que

A população brasileira em geral depositou confiança na Constituição de 1988. Acreditou que a mesma seria a balizadora das políticas do Estado, sobretudo, guardiã dos direitos individuais e coletivos. Entre 
as comunidades negras havia a expectativa de que suas terras seriam regulamentadas em breve, pois como assinalado, pela primeira vez foi aprovada uma Lei específica para este segmento social, no tocante à regularização fundiária. No entanto, o sonho tornou-se um pesadelo, pois as titulações não aconteceram. (FIABANI, 2014, p.62)

Entendemos que, tratados os percursos históricos, políticos e sociais que resultaram na formulação e planejamento dessas ações, o próximo passo constituise no desafio de compreendermos as prerrogativas constitucionais e os instrumentos normativos, que fundamentam os atos administrativos de implementação das ações de titulação das terras quilombolas, para que, em seguida, possamos travar uma discussão referente à análise direta de sua execução pela administração pública federal.

Nesse sentido, passaremos a discorrer a respeito da regulamentação e normatização da titulação das terras quilombolas no arcabouço jurídicoadministrativo brasileiro, assim como dos embates e conflitos institucionais, que se desencadearam para a definição das atribuições, para execução dessas atividades no âmbito da administração pública federal. Por fim, realizaremos uma análise a respeito dos procedimentos administrativos que regulamentam a regularização das terras quilombolas no âmbito federal. 


\section{CAPÍTULO III - Regularização das Terras Quilombolas: da previsão constitucional à normatização dos instrumentos administrativos}

Conforme demonstrado no capítulo anterior, um dos pilares que sustentam as ações de regulamentação de territórios no Brasil é o Artigo 68 do ADCT. Contudo, existe uma série de divergências, travadas especialmente no âmbito jurídico, acerca da necessidade ou não de se realizar a regulamentação desse dispositivo constitucional, salientando alguns estudiosos que tal artigo é auto-aplicável, ou seja, não dependeria de nenhum tipo de regulamentação por parte do Congresso ou do Executivo para que os títulos das terras quilombolas fossem devidamente emitidos a essas comunidades, uma vez que basta ao estado reconhecer um cenário que está instalado no cotidiano das comunidades remanescentes de quilombos que estejam ocupando suas terras.

Contudo, a despeito da corrente que defende a auto-aplicabilidade do texto constitucional, é fato que foram vários os movimentos que tiveram como objetivo regulamentar esse direito via projeto de lei no Congresso Nacional (Câmara dos Deputados e Senado Federal) ou por iniciativa do próprio Poder Executivo Federal (Presidência da República, via medidas provisórias ou decretos).

O que se propõe nesse capítulo é identificar nas relações políticas e institucionais desencadeadas pelo processo dinâmico de regulamentação desses direitos étnicos territoriais alguns fatores para a análise geopolítica da questão quilombola no Brasil, sobretudo a partir da perspectiva da atuação do próprio Estado e Governo. Além das iniciativas do Congresso e Executivo para regulamentação desse dispositivo, também serão abordadas as disputas interinstitucionais pelas atribuições da regularização de territórios quilombolas, especialmente entre 0 Instituto de Colonização e Reforma Agrária (INCRA) e a Fundação Cultural Palmares (FCP). Serão também objeto essencial de nossa análise os Decretos 4883 e 4887 de novembro de 2003, que definiram novos paradigmas para a titulação das terras quilombolas no Brasil, assim como suas consequentes normatizações realizadas pelo INCRA. Por fim, será realizada uma síntese dos procedimentos administrativos para titulação de terras quilombolas atualmente vigentes na legislação brasileira. 


\section{1 - A regulamentação do Art. 68 do ADCT: das iniciativas parlamentares à atuação do Executivo}

O processo de regulamentação do Artigo 68 do ADCT percorreu especialmente os mandatos dos Presidentes Fernando Henrique Cardoso (1995 a 2012) e Luiz Inácio Lula da Silva (2003 a 2010). Uma das características, mais devastadoras para o interesse dessas comunidades tradicionais, foi a grande quantidade e desconexão entre os instrumentos normativos que sustentaram as ações administrativas para emissão de seus títulos da terra, ou seja, os diversos e contraditórios procedimentos técnicos a serem adotados pelo órgão executor (FCP ou INCRA), para que fosse cumprido o rito burocrático que permitisse a geração do produto final: a emissão do título de domínio definitivo, que garanta a segurança fundiária da comunidade.

A primeira comunidade quilombola que experimentou uma ação pública que resultou na alteração de sua situação fundiária foi a Comunidade do Quilombo Frechal, por meio do Decreto Presidencial o 536 de 20 de maio de 1992, no mandato do então Presidente Fernando Collor de Mello. Esse procedimento teve como fundamento legal o art. 9º, inciso VI, da Lei oㅡ 6.938, de 31 de agosto de 1981, com a redação dada pela Lei oㅜ 7.804, de 18 de julho de 1989, ou seja, deu-se no âmbito da criação de uma Unidade de Conservação: Reserva Extrativista do Quilombo Frechal.

Em artigo dedicado à análise sobre as contradições implicadas na implantação do modelo de reserva extrativista, Ribeiro et al. [entre 2012 e 2015], explica que

Em 1974 com a chegada do intitulado proprietário da terra, trazendo consigo o absurdo do desmatamento e proibições, ou seja, novamente a escravidão. Este conflito chegou a durar 20 anos, mas 1985 cansados de tanta repressão, resolveram se organizar com um grupo assim mobilizando-se contra aquela exploração, foi fundada a Associação de moradores com participação de igreja junto com sindicato e diversas entidades de apoio, CCN (Centro de Cultura Negra do Maranhão) e a SMDH (Sociedade Maranhense de Direitos Humanos), onde juntos elaboraram um processo judicial da criação da Reserva Extrativista de Frechal, hoje conhecida no Brasil inteiro como Reserva Extrativista do Quilombo de Frechal, o reconhecimento de seus direitos e a luta afim de garantir a posse da 
terra, que há séculos vivem e cultivam no Quilombo de Frechal.

Não se trata, portanto, de um título de domínio de terras, emitido em favor da comunidade quilombola em si, mas de criação de uma unidade de conservação cuja gestão e regramento ficaram a cargo do IBAMA, conforme os Artigos $2^{\circ}, 3^{\circ}$ e $4^{\circ}$ :

\begin{abstract}
Art. 2o Caberá ao Instituto Brasileiro do Meio Ambiente e dos Recursos Naturais Renováveis - IBAMA, realizar a permanente gestão, no sentido de assegurar o uso adequado e racional da área descrita no artigo anterior, deste Decreto, mediante plano de utilização. Art. $3^{\circ} \mathrm{O}$ Instituto Brasileiro do Meio Ambiente e dos Recursos Naturais Renováveis - IBAMA, quando da implantação, proteção e administração da Reserva Extrativista do Quilombo Frechal, poderá celebrar convênios com as organizações legalmente constituídas, tais como cooperativas e associações existentes na reserva para definir as medidas que se fizerem necessárias à implantação da mesma. Art. 4ㅇ A área de reserva extrativista, criada nos termos deste Decreto, fica declarada de interesse social, para fins ecológicos, na forma da legislação vigente, ficando o Instituto Brasileiro do Meio Ambiente e dos Recursos Naturais Renováveis IBAMA autorizado a promover as desapropriações que se fizerem necessárias, respeitado 0 direito dos remanescentes das comunidades dos quilombos, nos termos do art. 68 do Ato das Disposições Constitucionais Transitórias.
\end{abstract}

Ribeiro et al [entre 2012 e 2015] reconhece que a proposta da criação da Reserva foi uma forma de legitimar a posse, direitos e reconhecimento aos trabalhadores que ali vivem há muitos anos, haja vista a inexistência de normas que regulamentassem o Artigo 68 do ADCT. A não regulamentação do Artigo 68 do ADCT é, inclusive, um dos elementos que marcaram os primeiros anos que sucederam a promulgação da nova Constituição, o que gerou iniciativas controversas como a evidenciada na comunidade de Frechal.

As primeiras iniciativas parlamentares que tentaram regulamentar o Artigo 68 do ADCT foram protocoladas no ano de 1995. A primeira delas é o Projeto de Lei do Senado o 129 de 1995, apresentado pela então senadora Benedita da Silva, que propunha o respectivo processo administrativo de discriminação das terras onde os remanescentes dos primeiros ocupantes das comunidades dos quilombos manteriam morada habitual. Seria regido, no que coubesse, às disposições previstas 
na Lei 6.383 de 07 de dezembro de 1976, que dispõem sobre o processo discriminatório de terras devolutas da União e dá outras providências. Na Câmara, esse projeto recebeu redação final pelo Substitutivo $\mathrm{n}^{\circ} 3207$ de 1997 . O texto da Câmara foi aprovado em 18 de abril de 2002 com redação totalmente reformulada em relação ao projeto original da Senadora Benedita da Silva. Tendo retornado ao Senado para nova aprovação, o projeto foi levado à apreciação da Presidência da República, cargo à época ocupado por Fernando Henrique Cardoso. Em 13 de maio de 2002 foi publicada a Mensagem ํㅜ 370, referente ao veto integral do projeto, por inconstitucionalidade e contrariedade ao interesse público.

\begin{abstract}
Verifica-se, primeiramente, que esse dispositivo constitucional confere o direito de propriedade "aos remanescentes das comunidades dos quilombos" e não "às comunidades remanescentes dos quilombos", como estabelecido no art. 1으 do autógrafo, que está, na verdade, a transferir o direito de propriedade assegurado constitucionalmente aos remanescentes para a comunidade da qual fazem parte. Vale dizer: o direito individual dos remanescentes fica transformado, por força do projeto, em direito coletivo da comunidade. Sem dúvida, ao assim preceituar, 0 art. $1^{\circ}$ do projeto contraria o art. 68 do ADCT e, por isso, é inconstitucional. (Mensagem da Presidência da República. DOU no 91, de 14 de maio de 2002, p. 25)
\end{abstract}

Além de contestar o direito de propriedade coletiva das terras, o veto também fundamentou-se nas premissas de que deveriam ser excluídos da propriedade das terras os remanescentes que, em 5 de outubro de 1988, não mais ocupavam as terras que até a abolição da escravidão formavam aquelas comunidades. 
Conclui-se, portanto, que o constituinte de 1988 visou a beneficiar tão-somente os moradores dos quilombos que viviam, até 1888, nas terras sobre as quais estavam localizadas aquelas comunidades, e que continuaram a ocupá-las, ou os seus remanescentes, após o citado ano até 5 de outubro de 1988. Ora, os incisos I, III e IV do parágrafo único do art. 1ํㅡ, ao inserirem dentro das terras cuja propriedade é reconhecida aos remanescentes das comunidades dos quilombos, áreas que não eram por essas pessoas ocupadas à época da entrada em vigor da Constituição de 1988, alargou inconstitucionalmente o alcance do art. 68 do ADCT, que - frise-se assegura a propriedade somente sobre as terras que eram ocupadas pelos quilombolas até 1888 e que continuavam a ser ocupadas pelos seus remanescentes em 5 de outubro de 1988. (Mensagem da Presidência da República. DOU no 91, de 14 de maio de 2002, p. 26)

Outras premissas que fundamentaram o veto presidencial se basearam na rejeição:

- À "categoria de auto-definição", sustentando a necessidade de haver registros factuais "da ocupação centenária das terras que, outrora, formavam os quilombos";

- Da legitimidade do Ministério Público em requerer a instauração do procedimento administrativo, uma vez que considera não se tratar "de direitos difusos ou coletivos, mas sim de direitos individuais dos remanescentes, que deles podem dispor a qualquer tempo";

- À perspectiva de titulação de terras que não eram ocupadas pela comunidade na promulgação da Constituição de 1988.

Sobre essa última assertiva, o veto presidencial reforça ainda que:

(...) é inadmissível a desapropriação de terras ocupadas por remanescentes das comunidades dos quilombos que visa a reconhecer a estes a propriedade daqueles imóveis. A autorização constitucional para a intervenção do Estado nos casos disciplinados pelo citado artigo cinge-se à emissão de títulos de propriedade. (Mensagem da Presidência da República. DOU no 91, de 14 de maio de 2002, p. 26)

À nossa perspectiva, sob o texto constitucional, o veto presidencial sustentouse em premissas equivocadas, uma vez que: 
- Cabe à própria comunidade, e não ao estado, decidir se a titulação do território será realizada de forma coletiva ou individual, ou seja, por comunidade ou por remanescente. Esse ponto, entretanto, não foi corrigido nem mesmo pelo Decreto 4.887 de 2003, conforme veremos adiante;

- Algumas comunidades tradicionais sofreram processo de expropriação de suas terras após 1888 e por, isso não as detinham mais sob sua posse em 1988. São casos em que o estado não pode se omitir e deve, aplicando seu poder constitucional e concedendo o direito ao contraditório aos nãoquilombolas envolvidos, trabalhar pela desapropriação desses imóveis e posterior destinação à comunidade tradicional nos termos do Art. 68 dos ADCT;

- A titulação das terras quilombolas é um direito difuso e coletivo, com benefícios tangíveis e intangíveis à sociedade, pois busca a reparação de direitos historicamente negados a esses povos e busca a pacificação no campo. É legítimo, portanto, ao nosso entendimento, que o Ministério Público atue em defesa dos direitos das comunidades em qualquer etapa do processo.

O segundo dispositivo foi apresentado na Câmara dos Deputados pelo Deputado Alcides Modesto e outros, constituindo-se no Projeto de Lei ํo 627 de 1995. Trata-se de um documento bem mais amplo e com proposições bem mais minuciosas que aquele apresentado no Senado. Inicialmente, por vincular como Patrimônio Cultural Brasileiro não apenas as terras ocupadas pelos remanescentes dos antigos quilombos, mas também aquelas áreas detentoras de recursos ambientais necessários à conservação dos usos, costumes e tradições, assim como também os sítios que contenham reminiscências históricas dos antigos quilombos. Dessa forma, o projeto parte da visão de que o Artigo 68 do ADCT não deve ser tomado como norma isolada no corpo da Constituição Federal. A delimitação do conceito de remanescentes de quilombos também era mais ampla, estabelecendo que 
(...) consideram-se remanescentes de comunidades de quilombos, para os efeitos dessa lei, aquelas populações que guardem vínculo histórico e social com antigas comunidades formadas por escravos fugidos, que lograram manter-se livres durante a vigência das leis escravistas do país. (Projeto de Lei no 627 de 1995)

Nessa mesma proposta, os procedimentos administrativos seriam executados por grupo técnico, designado pela Fundação Cultural Palmares (FCP), oriundos de suas respectivas associações científicas, diferentemente da proposta do Senado que estipulou o INCRA como órgão executor, por tratarem-se de áreas rurais e pela manifesta razão de ser essa a agência governamental mais habilitada para esses trabalhos.

Um importante aspecto abordado por essa proposta refere-se à forma de titulação das terras, apontando a necessidade da titulação coletiva e da inalienabilidade do imóvel titulado:

Deve-se considerar que, em se tratando de comunidades cujo uso da terra é feito de forma comunal, a titulação individual não é a mais adequada e contraria o disposto no artigo 216 do Corpo Permanente da Constituição Federal, posto que implica em estabelecimento de novo modo de ocupação da terra, interferindo no modo de fazer e viver da comunidade em sua identidade, que a constituição visa atender. Além disso, a cláusula de inalienabilidade das terras é necessária, já que a alienação dessas terras a terceiros implicaria na passagem do bem a outrem que não o grupo que encontra naquelas terras a referência à sua identidade, ação e memória. A proteção do patrimônio cultural brasileiro exige essa condição, portanto. (Projeto de Lei no 627 de 1995)

O Projeto de Lei o 627 de 1995 é claro ao posicionar-se pela ampliação do fundamento do Artigo 68 do ADCT, servindo, portanto, não apenas à sua finalidade fundiária (emissão dos títulos das terras), mas também como instrumento da proteção da identidade e do patrimônio cultural brasileiro, combinando para tal outros dispositivos constitucionais, especialmente aos artigos 215 e 216, que tratam da proteção ao patrimônio cultural brasileiro, conceituado como

(...) os bens de natureza material e imaterial, tomados individualmente ou em conjunto, portadores de referência à identidade, memória e ação dos grupos formadores da sociedade 
brasileira, nos quais se incluem as formas de fazer, criar e viver de cada um desses grupos, dentre os quais estão os remanescentes dos antigos quilombos. (Projeto de Lei № 627 de 1995)

Após avançar algumas das etapas do rito burocrático estabelecido pela sistemática que regula a Câmara dos Deputados, o Projeto de Lei oㅡ 627 de 1995 foi enviado à Comissão de Constituição e Justiça e de Redação em 26 de novembro de 1998, naquela que seria o último avanço do Projeto naquela casa legislativa, tendo sido arquivado no início da próxima legislatura, em 02 de fevereiro de 1999, nos termos do Artigo 105 do Regimento Interno da Câmara dos Deputados:

Art. 105. Finda a legislatura, arquivar-se-ão todas as proposições que no seu decurso tenham sido submetidas à deliberação da Câmara e ainda se encontrem em tramitação, bem como as que abram crédito suplementar, com pareceres ou sem eles, salvo as: I - com pareceres favoráveis de todas as Comissões; II - já aprovadas em turno único, em primeiro ou segundo turno; III - que tenham tramitado pelo Senado, ou dele originárias; IV - de iniciativa popular; V - de iniciativa de outro Poder ou do Procurador-Geral da República. Parágrafo Único: A proposição poderá ser desarquivada mediante requerimento do Autor, ou Autores, dentro dos primeiros cento e oitenta dias da primeira sessão legislativa ordinária da legislatura subsequente, retomando a tramitação desde o estágio em que se encontrava. (Câmara dos Deputados - Regimento Interno, p. 58)

Destacamos que, tendo em vista o que dispõe o regimento interno da Câmara, o fato de o autor do Projeto de Lei, Deputado Alcides Modesto não ter se recandidatado para mais uma legislatura representou um golpe decisivo para o arquivamento de seu projeto.

Há que se destacar ainda a existência do Projeto de Lei no 3.654 de 2008, de autoria do Deputado Federal Valdir Collato (PMDB/SC) que, segundo Fiabani (2013, p. 57)

(...) tem por objetivo regulamentar o artigo 68 da ADCT de modo a restringir os direitos das comunidades quilombolas. $O$ referido deputado quer mudar o sentido de "remanescente de quilombo' a fim de limitar o número de comunidades com direito à titulação. Deseja também, viabilizar a titulação individual das terras. Tanto o Partido Democrata quanto o deputado Colatto estão defendendo os interesses dos grandes proprietários, do agronegócio, dos especuladores de terras. A ADI 3.239 visa o retorno da interpretação do Artigo 68 do ADCT, nos moldes do Decreto 3.912/2001, emitido pelo Presidente FHC. Trata-se de reação conservadora que impede 
as comunidades negras rurais, indígenas e pobres terem acesso à terra.

Segundo consulta realizada no sítio eletrônico da Câmara dos Deputados, o projeto foi arquivado em 20 de outubro de 2009, por força do art. 133 do Regimento Interno da Câmara dos Deputados, que estabelece que a proposição que receber pareceres contrários, quanto ao mérito, de todas as Comissões, que for distribuída, será tido como rejeitada e arquivada definitivamente por despacho do Presidente, dando-se conhecimento ao Plenário.

\section{2 - INCRA e FCP: disputas pelas atribuições da titulação das terras quilombolas}

Mesmo que sem a regulamentação do Artigo 68 do ADCT, ocorria uma disputa no seio do Poder Executivo, visando as atribuições regimentais pela titulação das terras das comunidades quilombolas, conforme destaca Trecanni (2006):

É importante destacar que mesmo sem a regulamentação, o Instituto
Nacional de Colonização e Reforma Agrária - INCRA (órgão criado
pelo Decreto-lei no 1.110 , de 09 de julho de 1970 , atualmente é uma
autarquia vinculada ao Ministério do Desenvolvimento Agrário) e a
Fundação Cultural Palmares - FCP (criada pela Lei 7.668 , de 22 de
agosto de 1988, vinculada ao Ministério da Cultura), começaram a
trabalhar na titulação. No começo, houve um período de muita
confusão e discordância sobre qual desses dois órgãos deveria
cuidar do assunto. Na prática, os dois conduziram processos de
titulação, cada um de um jeito diferente.

A Portaria ํo 25 da Fundação Cultural Palmares (FCP), ligada ao Ministério da Cultura se tornou, em 22 de agosto de 1995, após quase 07 anos da promulgação da Constituição Federal de 1988, o primeiro instrumento normativo destinado a regulamentar a emissão dos títulos de propriedade da terra às comunidades quilombolas nos termos definidos pelo texto constitucional. A Portaria no 25 da FCP dispõe, em 7 breves artigos 
(...) as normas que regerão os trabalhos de identificação e delimitação das terras ocupadas por comunidades remanescentes de quilombos, de modo geral, também denominadas Terras de Preto, a serem procedidos por Grupo Técnico, como parte do processo de titulação, nos termos desta Portaria.

Dentre os aspectos mais relevantes da Portaria, destaca-se que seu escopo considerou a tentativa de combinar os dispositivos constitucionais, destinados à defesa do Patrimônio Histórico Brasileiro (Artigos 215 e 216 da Constituição Federal), o que ficou claro na exigência de elaboração de estudos "etnohistóricos e sociológicos", trazendo à baila a figura do "relatório antropológico", que resgate o histórico de ocupação da área com base na memória do grupo, dos que mostrem indícios da ancianidade da ocupação por meio da identificação de sítios arqueológicos, locais sagrados e de rituais, levantamento demográfico, de utilização econômica do território da comunidade, identificação e descrição dos limites da área de terras ocupadas pela comunidade, considerando para tal a distribuição espacial, seus usos e costumes, as terras imprescindíveis à preservação dos recursos ambientais necessários a seu bem-estar, assim como fatos e documentos históricos e uma avaliação do relacionamento da comunidade remanescente de quilombo com o Estado. O Artigo $5^{\circ}$ estabelecia a realização de "estudos fundiários, objetivando conhecer os bens de valor econômico pertencentes a intrusos e inseridos nos limites definidos da terra ocupada por comunidade remanescente de quilombo".

Não obstante, no dia 22 de novembro de 1995, é publicada no Diário Oficial da União a Portaria INCRA ํo 307 , assinada pelo Presidente do Instituto Nacional de Colonização e Reforma Agrária (INCRA), Francisco Graziano Neto, com o seguinte teor:

CONSIDERANDO que as comunidades remanescentes de quilombos acham-se sob a Proteção do Poder Público, por força da art. 68 do Ato das Disposições Constitucionais Transitórias, da Constituição Federal, que determina aos remanescentes das comunidades dos quilombos que estejam ocupando suas terras o reconhecimento da propriedade definitiva, com a consequente emissão dos títulos respectivos; CONSIDERANDO que cabe ao INCRA a administração das terras públicas desapropriadas por interesse social, discriminadas e arrecadadas em nome da União Federal, bem como a regularização das ocupações nelas havidas na formada Lei; CONSIDERANDO que as ações de Reforma Agrária conduzidas pelo Estado visam a promoção plena do homem, 
preservando seus valores sociais e culturais, integrando-o às peculiaridades de cada região, propiciando uma relação racional e equilibrada nas suas interações com o meio ambiente, resolve: I Determinar que as comunidades remanescentes de quilombos, como tais caracterizadas, insertas em áreas públicas federais, arrecadadas ou obtidas por processo de desapropriação, sob a jurisdição do INCRA, tenham áreas medidas e demarcadas, bem como tituladas, mediante a concessão de Título de Reconhecimento com cláusula "pró-indiviso", na forma do que sugere os Artigo 68 do ADCT; II Facultar a criação do Projeto Especial Quilombola, em áreas públicas federais, arrecadadas ou obtidas por processo de desapropriação para atender aos casos de quilombos com Títulos de reconhecimento expedidos pelo INCRA; III - Recomendar que os Projetos Especiais sejam estruturados de forma a não transigir em relação ao "status quo" das Comunidades beneficiárias, em respeito às condições suscitadas pelo Artigo 68 do ADCT e artigos 215 e 216 da Constituição Federal; IV - Determinar a Diretoria de Assentamento que defina instruções normativas, mecanismos e meios indispensáveis à criação e implementação de Projetos Especiais Quilombolas, de modo a assegurar a consecução dos fins por estes almejados; V - Incumbir a Diretoria de Assentamento de adotar as providências, objetivando orçamentar, provisionar e controlar os recursos destinados ao atendimento dos Projetos Especiais Quilombolas.

É evidente a divergência conceitual, filosófica e prática que separam as Portarias publicadas pela FCP e INCRA. Em síntese, é possível concluir que, enquanto a metodologia estabelecida pela FCP privilegia a reconstituição do percurso antropológico e histórico e da memória coletiva do grupo para "validar" o direito à terra como patrimônio histórico e cultural, a proposta do INCRA vai além, privilegiando, em suas ações, o lançamento de condições para a construção de alternativas de futuro às comunidades, propondo, inclusive, sua inserção como beneficiários da reforma agrária, via projeto de assentamento específico, para esse público.

Para que se possa dimensionar o quão benéfica teria sido a manutenção da Portaria 307 aos povos quilombolas, esse direito, de fato, só veio a ser garantido a partir da Portaria INCRA nº 175, de 19 de Abril de 2016, ou seja, com quase 21 anos de atraso. Esse lapso privou milhares de famílias quilombolas de ter acesso às políticas de financiamento produtivo, habitacional, de assistência técnica, educacional etc. garantidas aos beneficiários das políticas de reforma agrária.

A autarquia criou nesse processo de titulações uma rotina administrativa denominada "Projeto Especial Quilombola", que consistia numa adaptação simplificada daquela que já existia no 
órgão para a criação de assentamentos rurais em áreas públicas federais. De outro lado, a Fundação Cultural Palmares continuava insistindo na criação de condições técnicas para que ela atendesse as comunidades remanescentes de quilombos não apenas no plano do mapeamento e da militância cultural e educacional, mas também no de regularização fundiária. (CARVALHO, 2016, p. 133)

Curiosamente, a expedição do primeiro título de domínio de terras quilombolas ocorreu em 20 de novembro de 1995, dois dias antes da publicação da Portaria 307. A comunidade beneficiada foi a Boa Vista, composta por 112 famílias, localizada no município de Oriximiná (PA). Foram demarcados 1.125,0341 ha, desmembrados de uma Gleba de terras públicas denominada Trombetas.

Só depois de sete anos da vigência da Constituição foi expedido o primeiro título. O exemplo dos companheiros (as) de Oriximiná, no estado Pará, primeiro município brasileiro onde o governo federal outorgou um título de reconhecimento de domínio para os "remanescentes das comunidades de quilombos", em 20 de novembro de 1995, comprova a resistência inicial dos funcionários do Instituto Nacional de Colonização e Reforma Agrária - INCRA, que chegaram a afirmar: "nosso ordenamento jurídico não previa formas de titulação coletiva". Só a organização dos quilombolas garantiu que este direito saísse do papel e fosse colocado em prática. (TRECCANI, 2005).

Este autor destaca ainda que, entre 20 de novembro de 1995 e 20 de novembro de 1998, o INCRA expediu 06 títulos, todos no estado do Pará, perfazendo uma área total de 95.979,9744 hectares e beneficiando 567 famílias, tendo como referência a Portaria INCRA no 307 de 1995. Fiabani (2008, p.151) chama a atenção para esse mesmo fenômeno, concordando que as primeiras terras quilombolas foram tituladas em terras públicas, sem que o Artigo 68 da Constituição estivesse regulamentado:

Tratava-se, portanto, de regularizar terras públicas ocupadas por famílias de camponeses com alguma afro-descendência. No momento em que áreas pleiteadas passaram a incidir sobre terras de posse privada ou disputada por particulares, o processo de titulação tornou-se mais lento. 
Seguiram-se as disputas político-administrativas travadas entre INCRA e FCP pelas atribuições de titulação das terras quilombolas. Fiabani (2008, p.150) revela que para vários parlamentares, o INCRA era o órgão capaz de realizar o trabalho, pois possuía técnicos com experiência no trato com a questão agrária e estava, portanto, em vantagem em relação à $\mathrm{FCP}$, que por mais boa vontade que seus funcionários tivessem, não havia experimentado ainda o trabalho de demarcação $e$ regularização fundiária, do meu ponto de vista, fruto de sua centralização em Brasília em detrimento da enorme capilaridade do INCRA em todo o território nacional.

Contudo, mesmo com essas vantagens operacionais e de expertise, era latente a baixa eficiência do INCRA, enquanto órgão executor das ações de titulação das terras quilombolas, especialmente se comparadas aos resultados obtidos junto aos trabalhadores sem-terra nos assentamentos da reforma agrária (FIABANI, 2006). Sobre esse fenômeno, é necessário destacar a proposição de Santos (2012, p. 72), ao instruir que a luta dos quilombolas:

(...) se desenrolaram num espaço socialmente construído que estou denominando campo quilombola. Nesse campo, formado por segmentos sociais com interesses políticos e econômicos diversos, desenrolaram-se as lutas pelo poder econômico, político, cultural, social com vistas à obtenção de poder e de reconhecimento público. Um campo dinâmico em que uns se agrupam sobre os outros e em que as identidades são reafirmadas ou construídas. Os embates se constroem e se redefinem no campo das esferas públicas e ganham visibilidade.

Em 1997, mais um capítulo da batalha institucional travada entre FCP e INCRA foi escrito, a partir da elaboração de uma minuta de Decreto que foi apresentada à Presidência da República, que previa a retirada da competência do INCRA titular as terras quilombolas em favor da FCP.

A questão que se colocava era se o tema deveria ser trazido para o plano da reforma agrária ou se haveria a necessidade de se fundar um campo institucional novo no interior do Estado, sobre o qual a 
FCP passaria a ter monopólio nos moldes de uma Fundação Nacional do Índio (Funai). A ABA apoiava a Fundação Cultural Palmares para o desenvolvimento dessa tarefa e defendia que caberia a ela a indicação dos peritos aos laudos antropológicos que se fizessem necessários a aplicação do art. 68 do ADCT. (CARVALHO, 2016, p. 133-134).

Fiabani (2008) afirma que as entidades representativas se sentiram traídas e descontentes com os acontecimentos na esfera governamental, pois entendiam que a terra era assunto competente ao INCRA e não à Fundação Cultural Palmares, criada para zelar da cultura. Fiabani (2008, p.156) declara ainda que:

Quando a Fundação Cultural Palmares ofereceu-se para assumir a tarefa, no lugar do INCRA, órgão com experiência no trato da questão agrária, as comunidades sentiram que estavam sendo manipuladas. O movimento das comunidades negras visava a assegurar ou conquistar terra, e em segundo plano, preservar os espaços culturais.

A despeito da insatisfação do movimento negro com a possível transferência de atribuição de regularização das terras quilombolas do INCRA para a FCP, foi editada a Medida Provisória n 1.911 de 1999, que atribuiu ao Ministério da Cultura a competência de fazer cumprir o artigo 68 do ADCT, enquanto que a Portaria $n \cong 447$ de 1999 deu competência à Presidente da FCP para "praticar e assinar atos necessários ao efetivo cumprimento do disposto no Artigo 68 do Ato das Disposições Constitucionais Transitórias, atendidas as prescrições legais pertinentes".

Fiabani (2008, p.160) destaca que, dessa forma, "o ato presidencial retirou do INCRA a função de continuar trabalhando na titulação das terras das comunidades negras". Fiabani (2008, p.161) é categórico ao afirmar que

A concentração de poderes nas mãos da presidência da Fundação Cultural Palmares teve conotação política; ou seja, isolou a questão numa entidade onde ele, o Presidente da República, tinha o controle. Temos a impressão de que o Presidente não querendo atender a todas as comunidades negras rurais que estavam reivindicando terra, manteve a acepção inicial da determinação constitucional, 
restringindo assim drasticamente o número de comunidades aptas a terem terras regularizadas segundo o artigo 68 do ADCT. Através da Portaria no 447/99, Fernando Henrique centralizou as ações decisórias num Ministério controlado pelo dirigente máximo do Brasil. O cargo de presidente da Fundação Cultural Palmares era de sua confiança, podendo ser substituído a qualquer momento. No caso do INCRA, os funcionários que atuam nos escritórios regionais são, em sua maioria, admitidos através de concurso público, relativamente independentes em suas ações. O presidente Fernando Henrique sabia que a Fundação Cultural Palmares não estava estruturada, na época, para reconhecer e titular as terras das comunidades negras. $\mathrm{O}$ ato político/administrativo do presidente deixou transparecer que havia intenção de frear o processo que vinha sendo conduzido pelo INCRA.

Entretanto, o instrumento que, finalmente, veio a regulamentar pela primeira vez o Artigo 68 do ADCT foi o Decreto 3.912, de 10 de setembro de 2001, estabelecendo as

(...) disposições relativas ao processo administrativo para identificação dos remanescentes das comunidades dos quilombos e para o reconhecimento, a delimitação, a demarcação, a titulação e o registro imobiliário das terras por eles ocupadas. (DECRETO FEDERAL no 3912 de 2001)

Essa regulamentação trouxe consigo uma inovação de extrema relevância, ao estabelecer a exigência de que as comunidades negras, para terem direito à regularização de suas terras, deveriam estar ocupando-as no período compreendido entre a Abolição da Escravatura (1888) e a promulgação da Constituição de 1988, ou seja, que comprovassem a posse ininterrupta de suas terras por pelo menos 100 (cem) anos.

Neste sentido, o artigo 68 serviria para regularizar eventuais situações agrárias nascidas de comunidades de escravos fugidos, identificados, anteriormente ao ato abolicionista, como por exemplo: Palmares, Malunguinho, Manoel Padeiro e outros. (...) Com um simples ato, o Presidente reduziu drasticamente o número de comunidades negras aptas a receberem terras através do artigo 68 do ADCT. Não querendo satisfazer demandas das comunidades negras por terra, FHC considerou as comunidades remanescentes de quilombos, somente aquelas que se originaram das comunidades 
de escravos fugidos, prejudicando grande parte do campesinato de matriz africana. (FIABANI, 2008, p. 162)

A FCP, que havia emitido/cooperado para a emissão de 15 títulos de domínio para comunidades quilombolas nos anos de 1999 a 2000, portanto, antes da edição do Decreto 3.912, não emitiu nenhum após sua publicação.

\section{3 - Os Decretos da Era Lula: Novos paradigmas para a titulação das terras quilombolas. Será?}

Esse quadro legislativo sofreu alterações efetivas apenas com a revogação do Decreto 3.912, em novembro de 2003, já no mandato do Presidente Luís Inácio Lula da Silva. Nesse novo contexto, capitaneado pelo Partido dos Trabalhadores (PT), é lançado o II Plano Nacional de Reforma Agrária e, no seu escopo, a Titulação e Apoio ao Etnodesenvolvimento de Áreas Remanescentes de Quilombos é instituído como um programa a ser executado. Inicialmente, o II PNRA aborda a questão quilombola realizando uma série de denúncias da ineficiência e da forma de gestão adotada pelo governo antecessor, argumentando que

O quadro atual é de invisibilidade destes grupos sociais perante o Estado e a sociedade. Isso em função do desconhecimento do real universo destas comunidades, da ausência de políticas públicas adequadas de reconhecimento dos territórios e da garantia do acesso a direitos sociais e econômicos e, ainda, da restrita destinação de recursos. (...) Passados 15 anos, apenas 71 comunidades foram tituladas, a maioria no estado do Pará e em terras devolutas. Um montante insignificante quando comparado com o total de 743 ou com as estimativas não oficiais que indicam a existência de mais de 2.000 comunidades. Persistem conflitos em 55 das áreas tituladas, a maioria decorrente da ocupação irregular por parte de fazendeiros, posseiros e até por projetos de órgãos dos governos estaduais e federal. Há ainda, casos de sobreposição destes territórios por unidades de conservação ambiental. (II PNRA, 2003, p.28-9) 
As proposições contidas no II PNRA para a reversão desse quadro consistiu nas seguintes medidas: o Ministério do Desenvolvimento Agrário (MDA), a partir do INCRA, foi escolhido por um Grupo Interministerial de Trabalho para concentrar as ações de titulação das terras quilombolas, inclusive com a possibilidade de se realizar desapropriações em áreas particulares prevendo, portanto, a remoção de dos ocupantes não-quilombolas das áreas reconhecidas, num processo denominado desintrusão.

O Plano reconhece que este setor apresenta demandas distintas daquelas apresentadas pelos acampados e assentados, com suas raízes culturais e religiosas específicas. Será implementada uma política de regularização fundiária que garanta o direito de uso e posse, bem como o acesso aos instrumentos de política pública que favoreçam a permanência dos quilombolas na terra, sob coordenação do Programa de Promoção da lgualdade de Gênero, Raça e Etnia, do MDA, em conjunto com o INCRA. (II PNRA, 2003, p.29)

Neste contexto, é criada a Secretaria de Promoção das Políticas de Igualdade Racial (SEPPIR), num processo que, mais tarde, convergiria na publicação dos Decretos 4.883 e 4.887, de 20 de novembro de 2003. Esta Secretaria, que tinha status de ministério, foi encarregada da gestão do Programa Brasil Quilombola PBQ que, dentre outros eixos, tratava da coordenação-geral das ações de titulação das terras quilombolas no seio da Administração Pública Federal.

A identificação desse marco jurídico-administrativo é extremamente importante, pois vincula uma nova era das ações de identificação e titulação das terras quilombolas no Brasil, pois, a partir desse ato, as atribuições da titulação das terras quilombolas são transferidas do FCP/Ministério da Cultura para 0 INCRA/Ministério do Desenvolvimento Agrário, restando à FCP apenas o reconhecimento da autoatribuição das comunidades, enquanto remanescentes de quilombolas. Sobre esse processo, Arruti (2009, p.103-5) aponta que

O Decreto realizou isso por meio do deslocamento institucional do tema: de uma atribuição exclusiva da Fundação Cultural Palmares (Ministério da Cultura) para uma atribuição partilhada entre vários 
ministérios, cujas ações deveriam ser coordenadas pela Seppir (Presidência da República), mas que tem no Incra (Ministério do Desenvolvimento Agrário) o principal de suas ações. Com isso podemos dizer que os quilombos deixaram de ser um tema exclusivo da política cultural para serem reconhecidos como uma parcela da população nacional que deve ser atendida de forma diferenciada pelo conjunto das políticas públicas redistributivas. Esta passagem teve dois efeitos associados. Por um lado, os quilombolas passaram a ocupar a pauta da problemática agrária e agrícola brasileira, ainda que sob um estatuto ambíguo e frágil, no qual se conjugam elementos que emergem da experiência legal, administrativa e técnica das políticas de reforma agrária (redistributiva) e indigenista (de reconhecimento). Por outro lado, a ampliação das políticas de que são público aumentou também o espaço institucional, político e orçamentário das comunidades quilombolas e do seu movimento organizado em âmbito nacional, desencadeando uma forte reação por parte dos interesses ruralistas no Congresso Nacional, mas também de uma reação mais genérica à expansão das políticas de reconhecimento, defesa e mesmo de incentivo à diversidade social e cultural. De quase folclóricos, enfim, os quilombolas tornaram-se ativistas incômodos, localizados no mapa político nacional em algum lugar entre trabalhadores sem terra, os indígenas, as favelas e os universitários cotistas.

Tendo em vista a fala de Arruti (2009) e a matriz de análise das ações de titulação de terras quilombolas como referência, entendemos que esse momento representa um novo ciclo de abordagem dos resultados, pois a assunção de um Governo com um discurso ideológico e orientação político-partidária tradicionalmente mais próxima dos movimentos negros brasileiros representaria a esperança de um novo frescor para a formulação de novos critérios, princípios e diretrizes para o atendimento das demandas quilombolas e da conveniência político-administrativa das decisões favoráveis a esses grupos. A partir desse novo momento, esperava-se a criação de um ambiente favorável ao estabelecimento de novos parâmetros para as análises de custos financeiros, sociais e políticos, além do ponto crítico da política: o controle da agenda pública e a ingerência política em assuntos técnicos. Em síntese: os povos quilombolas estariam, enfim, ao lado "de quem governa".

Para Fiabani (2008, p.167), com o advento do Decreto 4.887 de 2003 "superava-se, portanto o óbice limitativo da concessão de terras apenas aos que podiam comprovar que eram remanescentes de comunidades de escravos fugidos", numa referência ao conceito tradicional de quilombos, conforme tratado 
anteriormente. Arruti (2009, p.103) também classifica o ano de 2003 como uma referência para as ações de titulação das terras quilombolas, ao assumir que

(...) o ano de 2003 marcou o início de uma etapa de aprofundamento daquilo que havia sido feito de forma apenas tentativa e semanticamente vacilante na Constituição de 1988: uma ruptura com a "afinidade eletiva" entre o "negro" e a "cultura" no trato dado ao tema das relações raciais por parte do Estado brasileiro. O debate que resultou na redação final do artigo sobre os "remanescentes das comunidades de quilombos" e que partiu ao meio a sua formulação original, já havia levando uma parte dos seus objetivos para o capítulo da cultura (CF88, artigos 215 e 216), enquanto deixava a outra, relativa aos objetivos fundiários, entre os dispositivos constitucionais transitórios (CF88 - 68 ADCT). Uma repartição que está muito próxima, senão perfeitamente decalcada, da oposição entre reconhecimento e redistribuição. Mas foi só com o decreto presidencial de 2003 que o Governo Federal abriria caminho, 15 anos depois, para que o tema das terras das comunidades negras fosse efetivamente incorporado como objeto de política pública em âmbito nacional. (Arruti, 2009, p.103)

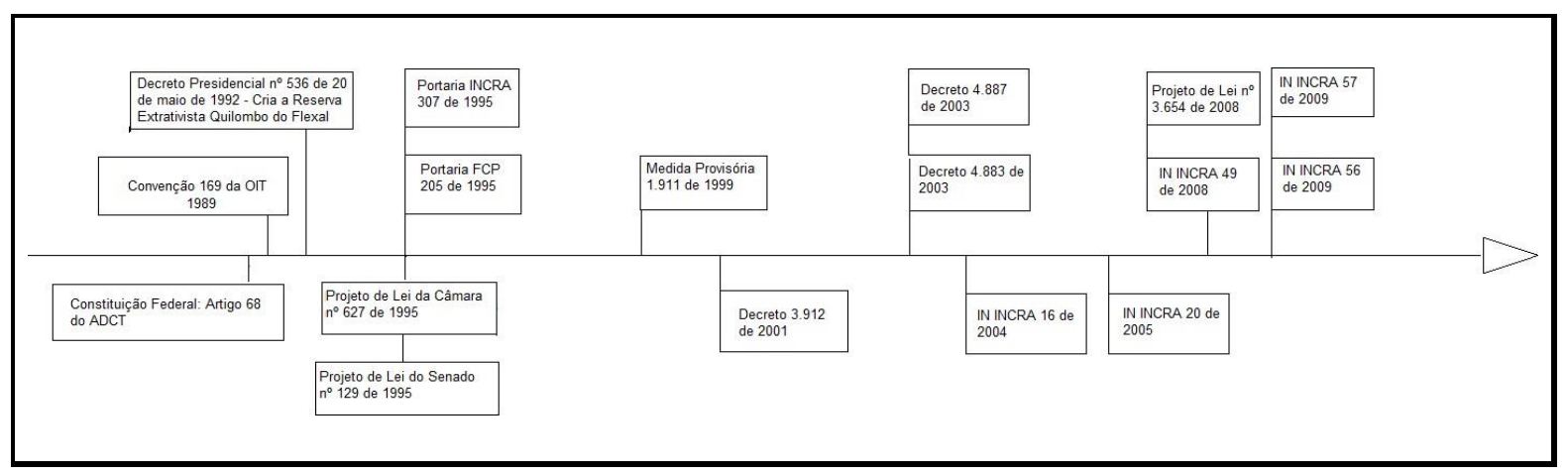

Figura 02: Legislação da Titulação das Terras Quilombolas: da previsão constitucional, dos decretos e da normatização (1988 a 2016).

Ao passo que se propõem a analisar o Programa Brasil Quilombola (PBQ) no contexto da Política Pública de Promoção da lgualdade Racial, os trabalhos desenvolvidos por Rodrigues (2010; 2012) são muito relevantes, seja pela compreensão dos caminhos político-institucionais percorridos até a criação da SEPPIR, ou seja pela análise das ações de titulação das terras quilombolas enquanto ferramentas de Estado para intervenção social. 
De início, podemos destacar na fala de Rodrigues (2012, p.177), o significado prático e simbólico da emergência do PT à Presidência da República:

É criada a SEPPIR [em 2003] como espaço de fomento de políticas de promoção da igualdade racial. Uma militante do movimento negro e de mulheres assume a pasta de ministra. Uma primeira missão: criar o PBQ - Programa Brasil Quilombola.

Amparada em depoimento de Matilde Ribeiro, ex-ministra da SEPPIR no governo Lula, Rodrigues (2012, p.181) salienta que

(...) dois pontos se destacam no processo de construção da SEPPIR: a transição dos governos FHC-LULA e a composição de forças para vencer a disputa política pela gestão do órgão. Em cada um deles o protagonismo do movimento negro como um ator ativo se faz notar. (...) A SEPPIR se constrói como demanda em Durban ${ }^{4}$, sendo incorporada à pauta dos movimentos negros na transição para o governo Lula. Lembrando, que anteriormente no Governo FHC foram dados os passos iniciais para a criação do GTI - Grupo de Trabalho Interministerial para a valorização da População Negra em 1996, responsável pelo conjunto de propostas levadas à Durban. Porém essas propostas estavam aquém das expectativas dos movimentos negros, especialmente pelo seu carácter mais próximo da ideia de uma política de reconhecimento do que de redistribuição.

Ao explicar a questão dos territórios quilombolas na SEPPIR, Rodrigues (2012, p.183) relata a atuação da Coordenação Nacional de Articulação de Comunidades Negras Rurais Quilombolas (CONAQ) como fundamental para a inclusão da pauta da regularização das terras quilombolas no âmbito da agenda governamental, trazendo consigo a necessidade de revogação do Decreto 3.912 de 2001,

(...) o qual se configurava como um entrave à luta quilombola por dois aspectos: exigir a ocupação ininterrupta no território por um período de 100 anos, ou seja, de 1888 a 1988 e delegar à Fundação

4 III Conferência Mundial de Combate ao Racismo, Discriminação Racial, Discriminação Racial, Xenofobia e Intolerância Correlata, 31 de agosto a 8 de setembro de 2001, Durban - África do Sul. 
Cultural Palmares os trâmites administrativos e técnicos da titulação quilombola.

Treccani (2005), por sua vez, destaca a atuação da Comissão Pró-Índio de São Paulo que sugeriu que se lembrasse a celebração da Lei Áurea, editando um decreto que, além de revogar o decreto em vigor, transferia a competência de todo o processo de titulação para o INCRA. Assim, é criado um contexto que lançou as bases para a constituição de um grupo de trabalho, formado por integrantes de 14 ministérios e 3 representantes das comunidades de quilombo indicados pela SEPPIR, e foi coordenado pela Casa Civil e pela própria SEPPIR, com as finalidades de rever o Decreto no 3.912, propor novas regulamentação para as ações de titulação das terras quilombolas, sugerir medidas para implementar o desenvolvimento das áreas já reconhecidas e tituladas pela FCP e INCRA.

O GT avaliou os trabalhos desenvolvidos até então pelo governo
federal e pelos governos estaduais, apontando os avanços e recuos
acontecidos nestes anos, na definição da política de reconhecimento
de domínio, analisou as diferentes legislações estaduais e as
propostas apresentadas por entidades da sociedade civil, do governo
federal e alguns especialistas e elaborou a minuta que resultou nos
Decretos nos $4.883,4.885$ e 4.887 , todos de 20 de novembro de
2003 . Estes Decretos foram assinados num lugar carregado de
simbologia: Serra da Barriga, no município de União dos Palmares
(AL), no dia das comemorações do Dia Nacional da Consciência
Negra. (TRECCANI, 2005)

Ao provocar a discussão, a respeito do contexto, que possibilitou a emersão e consolidação da regularização de territórios quilombolas, no seio das políticas públicas, Rodrigues (2010) efetua sua análise a partir do fenômeno da interconexão das arenas sociais e identifica os movimentos negros e comunidades quilombolas como empreendedores da política pública que via seu agenciamento político e atuação, em rede, transformar demandas em problemáticas, que chamam a atenção dos policy makers do governo. No âmbito governamental, o qual pode ser aqui subdividido nas esferas meso e macro, no começo há uma articulação em torno da formulação da política pública, considerando alternativas e escolhas que incidem não só sobre seu formato final, bem como sua implementação. Destaco aqui dois 
fatos exemplares sob essa ótica: a Instrução Normativa n 49/2008 do Incra e as negociações em torno do Estatuto da Igualdade Racial. (Rodrigues, 2010, p.274)

Porém, o que se constata, no relato das lideranças quilombolas e de outros atores, envolvidos no processo, é um grande descontentamento com o que é observado na prática, o que pode ser resumido na fala de Ivo Fonseca Silva em depoimento ao Instituto Socioambiental (ISA), resgatado no artigo de Fiabani (2014, p.68).

"Ganhamos o governo, mas não ganhamos o poder. Falta interesse
político não só do Presidente, mas de todas as instâncias", resume
Ivo Fonseca Silva, integrante da Coordenação Nacional de
Quilombos (Conaq) e da Associação das Comunidades Negras
Rurais Quilombolas do Maranhão (Aconeruq). Ele também não aceita
a opinião, defendida pelos técnicos do MDA, de que as dificuldades
administrativas e legais seriam o principal obstáculo para a
regularização dos quilombos. Silva garante que existem hoje, no
País, mais de cem territórios cujos processos já estão finalizados e
só aguardam a autorização do governo para receber a titulação.

Fabiani (2008, p.170) destaca ainda o depoimento de mais duas lideranças, que avaliam o contexto pós-Decreto 4887 de 2003:

Para a Coordenadora do Movimento Negro Unificado de Santa Catarina, Vanda Pinedo, "o número de comunidades tituladas não aumentou com o decreto 4.887". Não adianta boas intenções e suntuosas políticas públicas, "as comunidades precisam das terras". Para Vanda, um ponto positivo foi o resgate da identidade, "da identidade negra, da identidade quilombola". Por sua vez, ao tratar das comunidades negras do Rio Grande do Sul, o Coordenador Executivo do Instituto de Assessoria às comunidades Remanescentes de Quilombos (IACOREQ), Ubirajara Carvalho Toledo, tentou uma análise do atual momento. Para o coordenador, "a questão quilombola ganha projeção política a partir de ações realizadas pela Presidência da República e das iniciativas de diversos ministérios". No entanto, toda esta projeção não resultou em "melhoria das condições de vida das comunidades remanescentes de quilombos [...]". Ao comentar o Decreto n. 4.887/2003, Ubirajara assinalou que "É necessário que exista uma determinação baseada na vontade política e na confluência de diversos fatores para que a lei possa assumir um corpo e efetivamente constituir-se numa ação prática, de garantia de direitos constitucionais. As duas lideranças quilombolas citadas reclamaram da falta de objetividade do governo em relação às titulações de terra. Como afirmamos anteriormente, existem muitos fatores que retardam 0 processo e acabam prejudicando as comunidades. Por exemplo, a comunidade negra de Mata Cavalos, situada no município de Nossa Senhora do 
Livramento, no Mato Grosso, reclamou com o Presidente Lula da falta de estrutura da unidade do INCRA mato-grossense. Através de carta, a presidente Tereza Conceição Arruda escreveu: "é percebível a olho nu que o INCRA de Mato Grosso não está com nenhuma sensibilidade para disponibilizar servidores e materiais para efetuar um trabalho para regularizar as comunidades negras (grifo do autor)". $\mathrm{Na}$ correspondência, a presidente elogiou o esforço do funcionário do INCRA e expôs as precárias condições de trabalho da instituição. (FIABANI, 2008, p.170)

No que se refere, especificamente, às ações de regularização das terras quilombolas, destacamos que o Decreto 4.883 transferiu essa competência da FCP para o INCRA, enquanto que o Decreto 4.887 regulamentou essas ações. A partir daí, atendendo a necessidade de se normatizar esses procedimentos em âmbito administrativo e institucional, surge uma série de Instruções Normativas - IN expedidas pelo INCRA, no intuito de estabelecer os procedimentos técnicos, a serem adotados no âmbito do processo administrativo, para subsidiar a emissão dos títulos de domínio.

\section{4 - A normatização do Decreto 4887: Do caos à prostração}

A primeira das instruções normativas, publicadas com vistas a estabelecer os procedimentos administrativos para a execução do Decreto 4.887 de 2003, foi a IN/INCRA 16, de 24 de março de 2004 que trazia, dentre as principais exigências para a instrução do procedimento administrativo, a elaboração de um Relatório Técnico de Identificação, que deveria conter as seguintes peças técnicas denominadas no documento como etapas: levantamento de informações cartográficas, fundiárias, agronômicas, ecológicas, geográficas, socioeconômicas e históricas, junto a instituições públicas e privadas; planta e memorial descritivo do perímetro do território, cadastro das famílias remanescentes de comunidades de quilombo; cadastramento dos demais ocupantes e presumíveis detentores de título de domínio relativo ao território pleiteado; levantamento da cadeia dominial dos títulos de domínio e outros documentos inseridos no perímetro pleiteado; parecer 
conclusivo sobre a proposta de território e dos estudos e documentos apresentados pelo interessado por ocasião do pedido de abertura do processo.

Interessante notar que não há nenhuma previsão na norma de elaboração de qualquer documento técnico de cunho estritamente antropológico, para sustentar a demanda da comunidade, bastando para tal "reconhecimento" a auto definição da comunidade, que "será demonstrada através de simples declaração escrita da comunidade interessada ou beneficiária, com dados de ancestralidade negra, resistência à opressão, cultos e costumes" (IN/INCRA 16 de 2004). Outra questão a ser levantada é que a IN/INCRA 16 de 2004 previa a utilização de estudos técnicos e científicos, já existentes.

Estes são dois dos aspectos mais relevantes que foram revistos pela IN/INCRA 20 de setembro de 2005. Este dispositivo passou a exigir a necessidade de comunicação prévia aos proprietários e ocupantes com antecedência de 03 dias antes dos inícios de trabalho de campo e a realização de um estudo antropológico, como peça técnica ${ }^{5}$ de um trabalho mais abrangente denominado Relatório Técnico de Identificação e Delimitação (RTID), ao passo que retirou a possibilidade de se utilizar estudos técnicos e científicos já existentes, obrigando assim a ser elaborada uma peça técnica inédita, exclusiva para aquele processo administrativo, que abarcasse:

a) as terras e as edificações que englobem os espaços de moradia; b) as terras utilizadas para a garantia da reprodução física, social, econômica e cultural do grupo humano a ser beneficiado; c) as fontes terrestres, fluviais, lacustres ou marítimas de subsistência da população; d) as terras detentoras de recursos ambientais necessários à preservação dos costumes, tradições, cultura e lazer da comunidade; e) as terras e as edificações destinadas aos cultos religiosos; f) os sítios que contenham reminiscências históricas dos antigos quilombos. (IN/INCRA 20 de Setembro de 2005)

Sobre o advento da necessidade do Relatório Antropológico, Carvalho (2016, p. 137) salienta que

\footnotetext{
$5 \quad$ Peça técnica é cada um dos produtos estabelecidos pela legislação para a instrução processual da regularização dos territórios quilombolas, como por exemplo o relatório antropológico, o levantamento fundiário, a planta e memorial descritivo do perímetro da área reivindicada etc. Cada um desses documentos é denominado, portanto, como uma "peça técnica".
} 
Para que possamos entender porque o relatório antropológico não era um item do RTID desde a primeira normatização do Incra, temos que retroceder à formulação do decreto no 4.887/2003. Muitos representantes das comunidades dos quilombos que participaram do Grupo de Trabalho Interministerial que elaborou a minuta do referido decreto entendiam que, na medida em que a caracterização de tais coletividades passaria da comprovação de uma ocupação centenária à autodefinição, o relatório antropológico não era necessário e que se fosse colocado como peça técnica obrigatória poderia representar um entrave aos processos de regularização fundiária desses grupos. Nesse processo de debate e formulação, a Associação Brasileira de Antropologia defendia explicitamente a obrigatoriedade dessa peça técnica nos processos de regularização dos territórios quilombolas, alegando a sua utilidade em situações de conflito e processos judiciais. Desse modo, ela não só reconhecia a importância do discurso antropológico nas disputas políticas, como defendia o seu uso na garantia de direitos a segmentos da população historicamente marginalizados. (CARVALHO, 2016, p. 136)

Sobre essa questão, O"Dwyer (2014, p. 82) afirma que

O entendimento do papel desempenhado pelos relatórios antropológicos pode variar, mas o fazer antropológico que orienta a elaboração desses relatórios como parte de processos administrativos apresenta uma explicação sobre construções identitárias, formas de organização social, práticas culturais e processos de ocupação territorial das comunidades de quilombo que pretendem o reconhecimento legal ao descrever os vínculos estabelecidos entre os grupos e as terras tradicionalmente ocupadas como sendo as necessárias à sua reprodução física e cultural, segundo seus usos, costumes e tradições. Este tipo de tradução etnográfica pode trazer subsídios para uma decisão governamental e igualmente fornecer elementos para que os grupos possam se defender de possíveis formas de intervenção estatal que possibilite apenas o reconhecimento de categorias étnicas, sem garantir as condições de reprodução de práticas culturais, modos de vida e territorialidades específicas.

É importante ressaltar que, apesar de passar a exigir a elaboração de um relatório antropológico como requisito para instrução desses processos administrativos, o INCRA até, então, não contava com profissionais habilitados para tal, ou seja, não havia antropólogos, em seu quadro funcional. Somente em 13 de outubro de 2005, é que foi lançado o primeiro edital com 45 vagas ofertadas para profissionais com essa habilitação, e as primeiras nomeações somente ocorreram 
em março de 2006, cerca de seis meses após a publicação da instrução. Desta forma, o exercício de 2006 iniciou-se com 316 processos de regularização de territórios quilombolas protocolados no INCRA e nenhum antropólogo.

A IN/INCRA 20 de dezembro de 2005 encontrou um cenário de bastante resistência política de grupos impactados pela efetivação desses direitos, o que resultou, primeiramente, na publicação da Portaria Fundação Cultural Palmares no 98 de 2007, que passava a exigir da comunidade quilombola não apenas o seu próprio autorreconhecimento como quilombolas, conforme estabelece a Convenção 169 da OTI, mas também de:

Art. 3o, III - Remessa à FCP, caso a comunidade os possua, de dados, documentos ou informações, tais como fotos, reportagens, estudos realizados, entre outros, que atestem a história comum do grupo ou suas manifestações culturais; IV - Em qualquer caso, apresentação de relato sintético da trajetória comum do grupo (história da comunidade). (...) Parágrafo $2^{\circ}$ A Fundação Cultural Palmares poderá, dependendo do caso concreto, realizar visita técnica à comunidade no intuito de obter informações e esclarecer possíveis dúvidas.

Art. 4ำ As comunidades quilombolas poderão auxiliar a Fundação Cultural Palmares na obtenção de documentos e informações para instruir o procedimento administrativo de emissão de certidão de autodefinição.

Para Arruti (2009), essas inovações são oriundas de um contexto marcado pela pressão de setores políticos, interessados no travamento das titulações de terras quilombolas, explicando que

Nos planos legislativo e judiciário, este embate (contra a consolidação dos direitos quilombolas) se traduz na proposição de um projeto de lei que busca sustar os efeitos do decreto presidencial 4887/2003 e uma Ação Direta de Inconstitucionalidade contra o próprio decreto. Como forma de mediar as perdas políticas que ameaçam com a queda do decreto, no final de 2007 o governo federal aceitou negociar com a oposição, decidindo adotar limites na aplicação do decreto por meio da alteração dos procedimentos de reconhecimento e de regularização fundiárias previstos pelo decreto. (ARRUTI, 2009, p.90) 
Contudo, a Convenção 169 da OIT estabelece que mudanças nas políticas públicas voltadas às populações tradicionais devem ser submetidas às mesmas, sob forma de consultas formais.

\begin{abstract}
Se no caso das mudanças operadas pela FCP não houve maiores reações, em função do lugar periférico ocupado pelo órgão no processo de regularização fundiária; no caso da alteração da Instrução Normativa do INCRA houve grande reação por parte do movimento quilombola, assessores e estudiosos do tema. Em resposta a tal reação o governo tentou, primeiro, realizar uma consulta de forma improvisada e sem convocação oficial antecipada, lançando mão da presença de lideranças quilombolas em Brasília por outros motivos. Se esta tentativa tivesse obtido sucesso, a consulta teria sido um ato protocolar, puramente formal, realizado apenas para ratificar uma decisão que o governo já havia tomado. As lideranças quilombolas, porém, se recusaram a participar desta forma e propuseram transformar a Consulta Nacional em um processo de consulta amplamente informativo, participativo e de caráter nacional, que permita estabelecer um patamar mínimo de comunicação com o conjunto das comunidades quilombolas, informando-lhes sobre 0 objeto da consulta e colhendo delas, por meio de suas representações locais, estaduais e nacionais, as dúvidas, queixas, denúncias e sugestões que devem informar os debates. A Advocacia Geral da União (AGU), porém, recusou a proposta e impôs um formato de consulta sucinto, no qual, apesar de não conseguir impor os pontos fundamentais de sua proposta de mudança às lideranças quilombolas, manteve-os em suspenso para que o presidente da república tomasse a decisão de tertius. Seis meses depois da Consulta, a Instrução Normativa 49 foi publicada com o mesmo texto que foi rejeitado pelos quilombolas e denunciado pelas organizações da sociedade civil. (ARRUTI, 2009, p. 90)
\end{abstract}

Dentre as inovações trazidas por esse dispositivo, são destacadas a retirada da obrigatoriedade de se realizar o levantamento da cadeia dominial dos títulos de domínio identificados na área pleiteada, a exigência do chamado levantamento de sobreposições com unidades de conservação, áreas de segurança nacional, terrenos de marinha, terras públicas etc.. Não obstante, a IN/INCRA 49 de setembro de 2008 inclui outras inovações importantes e decisivas para o rito administrativo dos processos de regularização das terras quilombolas. Seria facultada às comunidades interessadas a apresentação de peças técnicas necessárias à instrução do RTID. Outra inovação tratava-se da possibilidade de o RTID concluir pela impossibilidade do reconhecimento da área estudada como terra ocupada por 
remanescente de comunidade de quilombo, além de estabelecer que o julgamento das contestações ficaria a cargo do Conselho de Direção Regional (CDR) das Superintendências Regionais do INCRA e não mais pela equipe técnica que elaborou o RTID.

Contudo, a inovação mais impactante para o travamento das ações de titulação das terras quilombolas foram as concessões que ampliaram a importância e o grau de complexidade do relatório antropológico, que se tornou muito mais denso e complexo do que nas instruções anteriores, ao passo que passaria a ser necessariamente realizado por antropólogos com vinculo funcional com o INCRA, salvo em hipótese devidamente reconhecida de impossibilidade material, quando poderia haver contratação, obedecida a legislação pertinente. Nesse contexto, a fala de Arruti (2009) é essencial, ao afirmar que:

(...) o Incra reeditou a instrução normativa que regula o processo de regulação fundiária quilombola, tornando-o mais complexo e lento: a certidão da FCP tornou-se obrigatória e os critérios de realização do RTID e, em especial, do relatório antropológico tornaram-se mais complexos, com a inclusão de uma longa lista de itens padronizados e obrigatórios inúteis e até mesmo perigosos, já que, apesar de nem todos os itens poderem ser preenchidos na descrição de todas as áreas, a sua existência na norma possibilita a argumentação puramente formal no plano jurídico, no sentido da sua impugnação. (ARRUTI, 2009, p.90 - grifo nosso)

Nesse contexto, a IN/INCRA 49 de setembro de 2008 vigorou até o dia 07 de outubro de 2009, sendo revogada pela IN/INCRA 56. Essa nova instrução representou certos avanços burocrático-administrativos que simplificariam consideravelmente o tempo de resposta do INCRA no que se refere à instrução dos processos de titulação das terras quilombolas, especialmente no maior gargalo do processo: o relatório antropológico. A IN/INCRA 56 de 2009 estabeleceu novos parâmetros para a elaboração dessa peça técnica, sintetizando-os nos seguintes termos:

O relatório antropológico de caracterização histórica, econômica, ambiental e sociocultural da área quilombola identificada, deve conter 
as seguintes descrições e informações sobre a comunidade pesquisada: a - informações gerais e dados disponíveis; $b$ - sua historicidade; c - sua etnicidade e organização social; $d$ - sua forma de produção e relação com o meio ambiente; e - proposta de território a ser titulado.

Obviamente que, se comparado ao texto da IN/INCRA 49, os parâmetros estabelecidos pela IN/INCRA 56 são muito mais generalistas e razoáveis ao que se espera de um processo de regularização fundiária. Contudo, a IN/INCRA 56 vigorou por apenas 13 dias: entre 07 e 20 de outubro, data em que foi publicada a IN/INCRA 57 , que a revogou, restabelecendo, em termos práticos, o mesmo texto da IN/INCRA 49.

No dia 7 outubro, o presidente do Incra publicou uma nova instrução normativa - a IN Incra no 56/2009 - que removia diversos dos entraves da IN 49/2008. O movimento de avanço incentivado por funcionários do "setor quilombola" do Incra foi rapidamente contido segundo eles mesmos "devido à pressão de setores que são favoráveis a manutenção dos entraves na política de regularização" . Assim 13 dias depois, a IN Incra no 56 foi revogada e a norma de 2008 (a IN Incra 49) foi republicada como Instrução Normativa Incra no 57 de 20 de outubro de 2009. (CPI/SP, 2009, p.04)

Esse processo representou, ao nosso entendimento, mais um duro golpe no histórico de fragilidade e ineficiência, a que as ações de titulação das terras quilombolas estiveram sujeitas. A Comissão Pró-Índio de São Paulo (CPISP) (2009, p. 03), traz uma hipótese para a compreensão desses processos, apontando que

O pífio número de titulações não é a única marca da política quilombola do governo Lula. Esta gestão foi responsável pela introdução de uma série de empecilhos burocráticos nos procedimentos para a regularização das terras quilombolas que resultaram na restrição dos direitos das comunidades. Os obstáculos foram acrescidos progressivamente por meio de sucessivas normativas: a Instrução Normativa Incra no 16/2004; a Instrução Normativa Incra ํㅡ 20/2005, a Portaria Fundação Cultural Palmares no 98/2007 e finalmente, a mais polêmica delas, a Instrução Normativa Incra no 49/2008. As exigências introduzidas a cada nova norma tornaram 0 processo mais moroso e custoso e, consequentemente, mais difícil de ser concluído. Por essa razão é que consideramos que as normas atuais cerceiam o direito 
reconhecido aos quilombolas pela Constituição Federal. É difícil aceitar que a motivação de tais mudanças seja realmente aquela anunciada pelo governo: a necessidade de aperfeiçoar as normas a fim de dar segurança jurídica ao processo e evitar futuros conflitos no judiciário. Em setembro de 2009, a Instrução Normativa Incra 49/2008 completou um ano de existência e, ao contrário do anunciado pelo governo, não se percebeu qualquer avanço na condução dos processos ou na resolução dos conflitos em função das novas regras. As sucessivas normas parecem ser muito mais uma concessão aos setores que manifestaram forte oposição aos direitos quilombolas do que um aperfeiçoamento. A primeira e mais significativa manifestação contrária foi a proposição em 2004 da Ação Direta de Inconstitucionalidade no 3239 pelo então Partido da Frente Liberal (atual Democratas) contra o Decreto no 4887/2003 que regulamentou o procedimento para titulação das terras quilombolas. A relação das instituições que ao longo dos anos requereram a entrada no processo como amicus curiae ao lado do propositor da ação é um bom indicativo dos interesses envolvidos na oposição aos direitos quilombolas: Confederação da Agricultura e Pecuária do Brasil, Confederação Nacional da Indústria, Associação Brasileira de Celulose e Papel, a Sociedade Rural Brasileira e o Estado de Santa Catarina. Em outubro de 2009, o episódio envolvendo a publicação e revogação de mais uma instrução normativa do Incra ilustrou de forma clara como o governo federal está suscetível às forças contrárias aos direitos quilombolas e como tal pressão repercute diretamente na definição de tais normas.

A análise deste processo nos permite concluir que as contradições e disputas que se desenrolaram política e institucionalmente para a normatização do Decreto 4.887 de 20 de novembro de 2003 representaram um verdadeiro caos administrativo no INCRA, o que penalizou grande parte das comunidades quilombolas, que viram suas demandas se perderem no emaranhado burocrático que se tornou o processo de regularização das terras quilombolas no Brasil. Em nossa perspectiva, isso cooperou para a instalação de uma verdadeira prostração da administração pública federal frente à questão quilombola, o que será demonstrada com mais elementos nos próximos capítulos. Antes, contudo, é necessário que se compreenda o passo-a-passo do rito processual para titulação das terras das comunidades quilombolas no Brasil.

\section{5 - Uma síntese dos procedimentos administrativos para titulação de terras quilombolas}

A IN/INCRA 57 de 20 de outubro de 2009 estabelece os procedimentos administrativos para a instrução dos processos de titulação de terras quilombolas, no 
âmbito do INCRA. Regulamenta, portanto, o procedimento para identificação, reconhecimento, delimitação, demarcação, desintrusão, titulação e registro de terras ocupadas por remanescentes de quilombos de que tratam o Artigo 68 do ADCT e Decreto 4887 de 20 de novembro de 2003.

A Figura 03 foi elaborada pela DFQ/INCRA com o objetivo de sistematizar o intrincado, conflituoso, contraditório e polêmico processo, que convergiu na legislação para titulação das terras quilombolas, que vigoram atualmente no Brasil.

Em linhas gerais, o procedimento pode ser sintetizado nos seguintes termos: a caracterização dos remanescentes das comunidades de quilombos é atestada mediante autodefinição, que deve ser certificada pela FCP, mediante Certidão de Registro no Cadastro Geral de Remanescentes de Comunidades de Quilombos do referido órgão. No INCRA, o procedimento administrativo terá início por requerimento de qualquer interessado, das entidades ou associações representativas de quilombolas ou de ofício pelo INCRA, sendo necessária a apresentação de informações sobre localização e da área, objeto da identificação. $O$ procedimento administrativo no INCRA pode ser instaurado sem a Certidão da FCP, porém não será realizada nenhuma ação sem a mesma ter sido anexada ao processo. Na prática, não existe um critério para determinação de quando serão iniciados os trabalhos de produção das peças técnicas, que compõem o chamado Relatório Técnico de Identificação e Delimitação (RTID), estando normalmente a critério de conveniência e oportunidade dos gestores das ações, em cada uma das superintendências regionais do INCRA. 


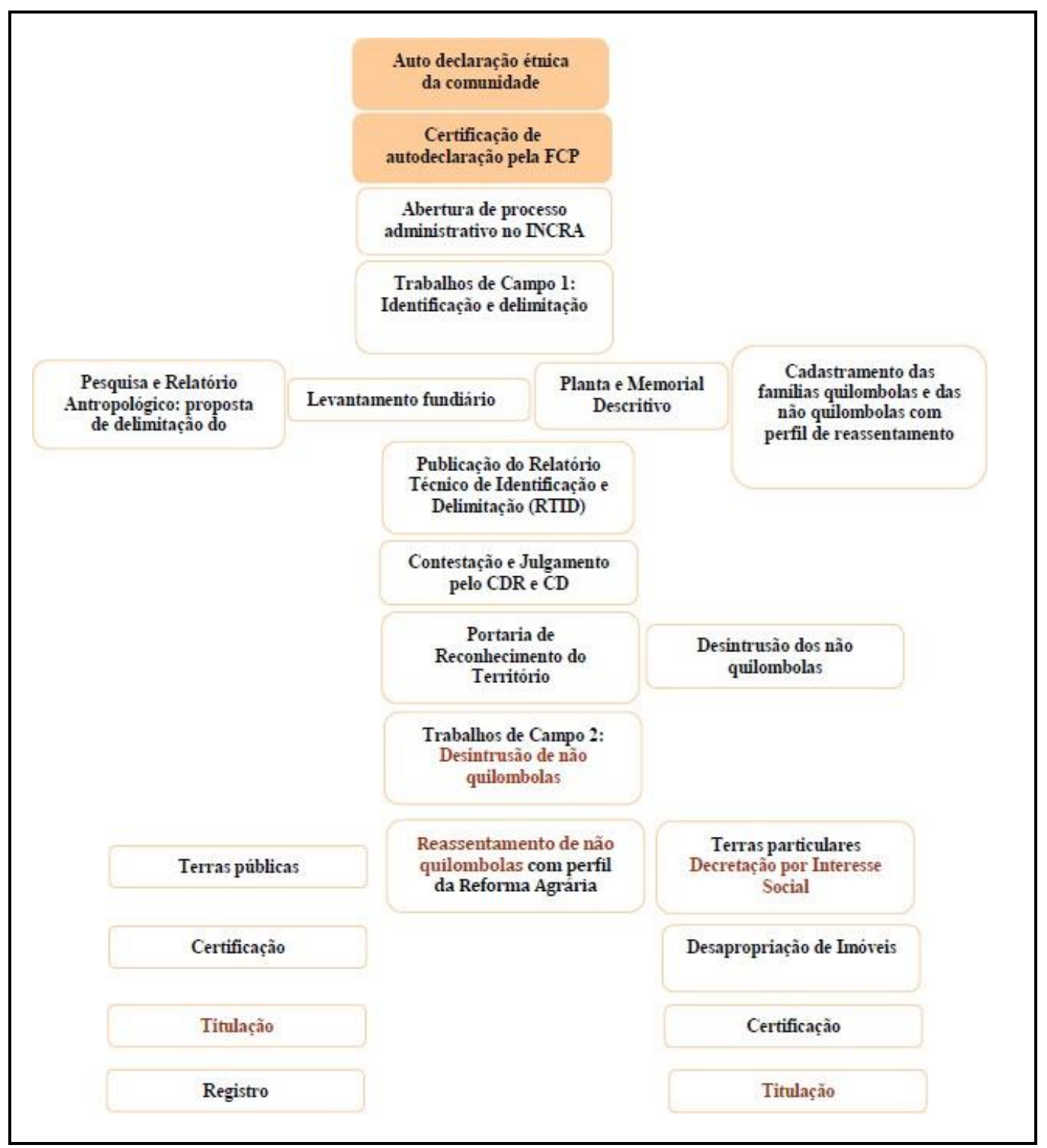

Figura 03: Fluxograma do Processo de Titulação das Terras Quilombolas. Fonte: DFQ/INCRA. Data não informada.

O RTID deve ser fundamentado em elementos objetivos, abordando informações cartográficas, fundiárias, agronômicas, ecológicas, geográficas, socioeconômicas, históricas, etnográficas e antropológicas, que deverão ser obtidas em campo e junto a instituições públicas e privadas. Trata-se de um documento fundamental no âmbito do processo administrativo, composto pelas seguintes peças técnicas:

- Relatório Antropológico de caracterização histórica, econômica, ambiental e sociocultural da área quilombola identificada; 
- Levantamento Fundiário, com identificação e censo de eventuais ocupantes não-quilombolas, com descrição das áreas por eles ocupadas, com a respectiva extensão, as datas dessas ocupações, e a descrição das benfeitorias existentes; descrição das áreas pertencentes a quilombolas que têm título de propriedade;

- Planta e memorial descritivo do perímetro da área reivindicada;

- Cadastramento das famílias remanescentes de comunidades de quilombos;

- Levantamento de situações em que as áreas pleiteadas estejam sobrepostas a unidades de conservação, área de segurança nacional, áreas de faixa de fronteira, terras indígenas ou outras terras públicas arrecadadas pelo INCRA ou Secretaria de Patrimônio da União e em terras do estado ou municípios.

- Parecer conclusivo da área técnica e jurídica sobre a proposta de área;

Dada a diversidade de elementos técnico-científicos a serem considerados na elaboração do RTID, que abrange diversas áreas do conhecimento, o Superintendente Regional designa, via Ordem de Serviço, um corpo de servidores das mais diversas habilitações para elaboração das peças técnicas. O chamado Grupo Técnico Interdisciplinar é geralmente composto por profissionais habilitados nas áreas da antropologia, agronomia, cartografia, geografia e técnicos de cadastro rural, assistentes administrativos, em geral etc., o que pode variar muito em decorrência do corpo de servidores disponível em cada uma das superintendências regionais. Não raro, servidores são convidados a realizarem trabalhos em outras superintendências devido ao fato de não haverem profissionais de determinada habilitação nesses quadros locais.

Os trabalhos de campo, que envolvem a elaboração dessas peças técnicas, deverão ser precedidos de comunicações prévias (ofícios ou notificações administrativas) a eventuais proprietários ou ocupantes das terras, localizadas no perímetro pleiteado pela comunidade tradicional, com antecedência mínima de 03 dias. Obviamente, essa exigência é um dos grandes gargalos operacionais das ações, pois implica em visitas aos proprietários e ocupantes não quilombolas que, geralmente, não se mostram receptivos ao pleito das comunidades e, não raramente, se recusam a receber as equipes técnicas do INCRA, encarregados de procederem a comunicação das atividades. Decorrido o prazo mínimo de 03 dias, a 
equipe poderá retornar ao imóvel, para colheita de documentos e informações que comporão o Levantamento Fundiário dos ocupantes não quilombolas, tais como certidões de registro do imóvel no Serviço Cartorário de Imóveis (SRI) ao qual o município está inserido, informações sobre as benfeitorias existentes a produção, uso, ocupação e exploração do solo, inclusive com relação ao atendimento à legislação ambiental e demais informações que a equipe técnica julgar relevantes. Dada a resistência de alguns proprietários e ocupantes em não cooperar com esse trabalho e não concordar com a entrada das equipes em seu imóvel, o INCRA deve solicitar respaldo no Poder Judiciário, para adentrar os imóveis e proceder às benfeitorias, muitas vezes com reforço policial, o que, evidentemente, tem o potencial de acirrar tensões e gerar conflitos na região reivindicada pelas comunidades tradicionais quilombolas. Não obstante, é cada vez mais frequente o uso de tecnologias do sensoriamento remoto no suporte à elaboração do Levantamento Fundiário, mas não são todas as áreas que contam com imagens de satélite ou fotografias aéreas com qualidade técnica suficiente, para se alcançar trabalhos definitivos. Sobrevoos e aquisição de imagens de satélite ainda são serviços e produtos que envolvem somas de recursos orçamentários e financeiros, que dificultam a sua disponibilização nas ações de regularização das terras quilombolas.

Ao fim da elaboração de todas as peças técnicas mencionadas, o RTID é, então, submetido à análise preliminar do Comitê de Decisão Regional (CDR) da Superintendência do INCRA onde está localizado o território quilombola. Esse Comitê, formado pelo Superintendente Regional, Chefes de Divisões e da Procuradoria Especializada (PFE/AGU), avaliará se o RTID atende aos termos exigidos para sua elaboração. Caso o CDR avalie que os critérios estabelecidos para a elaboração do RTID não foram cumpridos, o trabalho será remetido novamente ao Grupo Técnico Interdisciplinar para sua revisão ou complementação. Caso o CDR conclua pela impossibilidade do reconhecimento da área estudada como terra ocupada por remanescentes de quilombos, o CDR ouvirá os setores técnicos e a Procuradoria Regional e assim poderá determinar novos estudos complementares ou determinar o arquivamento do processo administrativo, o que poderá ser desarquivado apenas em situações onde haja justificativa, à critério da administração. 
Caso o RTID seja aprovado pelo CDR, o Superintendente Regional providenciará a elaboração e publicação de um Edital, por duas vezes consecutivas no Diário Oficial da União (DOU) e no Diário Oficial da unidade federativa onde se localiza o território pleiteado (DOE), contendo informações relativas à:

- Denominação do imóvel ocupado pelos remanescentes das comunidades dos quilombos;

- Circunscrição judiciária ou administrativa onde está situado o imóvel;

- Limites, confrontações e dimensão constantes do memorial descritivo das terras a serem tituladas;

- Títulos, registros e matrículas eventualmente incidentes sobre as terras consideradas susceptíveis de reconhecimento e demarcação.

Esse Edital será então encaminhado (cópia) à comunidade quilombola e à Prefeitura Municipal onde está situado o imóvel, para ser afixado na sede da prefeitura, acompanhado de memorial descritivo e mapa da área estudada. Uma cópia do RTID será encaminhado a cada um dos órgãos relacionados ao processo de titulação, para manifestação no âmbito de suas competências, dentro de um prazo de 30 dias. Os órgãos listados pela IN/INCRA 57 de 2009 são:

- Instituto do Patrimônio Histórico e Cultura (IPHAN);

- Instituto Brasileiro de Meio Ambiente e Recursos Naturais Renováveis IBAMA e seu correspondente na Administração Estadual;

- Secretaria de Patrimônio da União (SPU);

- Fundação Nacional do Índio (FUNAI);

- Secretaria Executiva do Conselho de Defesa Nacional (CDN);

- Fundação Cultural Palmares (FCP);

- Instituto Chico Mendes de Conservação da Biodiversidade (ICMbio) e seu correspondente na Administração Estadual;

- Serviço Florestal Brasileiro (SFB);

- Outros órgãos em que eventualmente o Presidente do INCRA verifique repercussão em suas áreas de interesse. 
Vencidos esses trâmites, o INCRA estará apto a iniciar o processo de notificação dos proprietários, ocupantes e confinantes dos imóveis identificados pelo Levantamento Fundiário. Inicialmente, esta notificação se dará de forma pessoal, ou seja, o técnico do INCRA ficará responsável por localizar e notificar todos os proprietários de todos os imóveis do Levantamento Fundiário. Situações em que, por exemplo, o imóvel tenha diversos proprietários, todos eles deverão ser notificados. Não é difícil constatar, portanto, que esse constitui mais um dos gargalos operacionais das ações.

Cada um dos proprietários terá o prazo de até noventa dias, contados a partir de sua notificação, para protocolar contestação administrativa ao RTID, junto à Superintendência Regional do INCRA. Essa contestação será julgada pelo CDR em até 180 dias constados a partir do seu protocolo. Se o julgamento da contestação concluir por alguma alteração no Edital, o mesmo deverá ser novamente publicado, ao passo que cada um dos proprietários será novamente notificado das alterações. Cabe recurso administrativo do julgamento das contestações realizado no âmbito do CDR ao Conselho Diretor (CD) do INCRA, na sede em Brasília, que deverá ser protocolado num prazo de até trinta dias, contados da notificação da decisão tomada anteriormente pelo CDR. Sendo provido o recurso pelo CD, o Presidente do INCRA publicará as alterações das informações contidas no Edital no DOU e no DOE, procedendo ainda a notificação do recorrente.

Concluída a fase de contestações, é comum aqueles proprietários e ocupantes não-quilombolas (ou até mesmo dentre os quilombolas), que tiveram suas contestações administrativas indeferidas, impetrarem com ações judiciais contra o pleito das comunidades quilombolas. Nesse contexto, a PFE/AGU passa a defender os interesses das comunidades tradicionais quilombolas.

Em situações em que as áreas pleiteadas pela comunidade incidam sobre áreas de unidades de conservação constituídas, áreas de segurança nacional, áreas de faixa de fronteira e terras indígenas, a Superintendência Regional do INCRA deverá, em conjunto com o respectivo órgão interessado e sempre ouvindo a SPU e FCP, adotar as medidas cabíveis, visando conciliar a sustentabilidade das comunidades e os interesses do Estado. Contudo, não é incomum haver uma divergência de interesses nesse sentido, o que ocasiona uma controvérsia que pode ser de ordem de mérito ou jurídica. Se for de mérito, o processo será encaminhado e a questão será resolvida no âmbito da Casa Civil da Presidência da República; se se 
tratar de uma questão jurídica, será encaminhado à Câmara de Conciliação e Arbitragem da Administração Federal (CCAF), órgão da Consultoria-Geral da União Advocacia-Geral da União.

A Câmara de Conciliação e Arbitragem da Administração Federal CCAF, órgão da Consultoria-Geral da União, foi criada pelo Ato Regimental no 05, de 27 de setembro de 2007, e tem sua forma de atuação regulamentada pela Portaria AGU $\mathrm{n}^{\circ}$ 1.281, de 27 de setembro de 2007, cujo objetivo principal é evitar litígios entre Órgãos e Entidades da Administração Federal. (AGU, 2008, p. 01)

No âmbito das ações de titulação das terras quilombolas, a CCAF representa uma instância de fundamental importância para a resolução de conflitos de interesses entre os órgãos da administração pública, sobretudo nos casos em que as terras reivindicadas pelas comunidades tradicionais quilombolas (INCRA) estão inseridas em unidades de conservação (ICMBio).

Concluídas com sucesso todas as fases até aqui estabelecidas, juntamente com a demarcação cartográfica do perímetro do território, nos parâmetros estabelecidos pela Lei 10.267 de 2001, o Presidente do INCRA publicará uma Portaria no DOU e DOE, reconhecendo e declarando os limites da terra quilombola, no prazo de 30 dias.

No caso de sobreposição com terrenos de marinha, terrenos marginais de rios federais e seus acrescidos, várzeas, ilhas e lagos, bem como áreas adquiridas ou atribuídas legalmente à União e geridas exclusivamente pela SPU/MP, é normativo o estabelecido pela Portaria Interministerial no 210 de 13 de junho de 2014, que delega ao extinto Ministério do Desenvolvimento Agrário (MDA), ao qual o INCRA era subordinado à época, a:

(...) competência para outorgar a beneficiários de projetos federais de assentamento de reforma agrária e a grupos remanescentes das comunidades dos quilombos a Concessão de Direito Real de Uso CDRU ou a transferência do domínio pleno de terrenos rurais da União, contemplados nos incisos I, III, IV e VII do art. 20 da Constituição Federal. (BRASIL, Portaria Interministerial ํㅡ 210 de 13 de junho de 2014) 
A IN/INCRA 57 estabelece ainda que, em caso de sobreposição das terras pleiteadas com propriedades dos Estados, do Distrito Federal e dos Municípios, a Superintendência Regional do INCRA encaminhará o processo administrativo para que o respectivo órgão proceda com a titulação, sendo prevista a proposição de convênio com as unidades da Federação, visando a titulação nos termos da legislação quilombola vigente.

Nos casos em que há incidência das terras reconhecidas e declaradas pela Portaria com títulos de domínio particular não invalidado por nulidade, prescrição ou comisso e nem tornado ineficaz por outros fundamentos, a Superintendência Regional do INCRA efetuará a obtenção dos respectivos imóveis, via desapropriação por interesse social. Sendo os ocupantes não-quilombolas aptos a serem enquadrados pela legislação agrária como passíveis de reassentamento, o INCRA o providenciará em áreas fora dos limites do território quilombola, num processo denominado desintrusão das famílias não-quilombolas.

Com a desintrusão ${ }^{6}$ das famílias não-quilombolas, procede-se à titulação coletiva e pró-indiviso das áreas reivindicadas, sem ônus financeiro e em nome da Associação quilombola legalmente constituída. O título de domínio é outorgado com obrigatória inserção de cláusula de inalienabilidade, imprescritibilidade e de impenhorabilidade, ficando a cargo do INCRA realizar seu registro no Serviço Registral da Comarca de localização do imóvel.

Contudo, em situações em que o processo de desintrusão ocorre de forma muito fracionada, ou seja, devido às grandes extensões do território, o elevado número de imóveis afetados ou mesmo pela morosidade processual, desencadeada pela judicialização de alguns processos, que podem se arrastar por vários anos, as áreas paulatinamente emitidas na posse em favor do INCRA podem ser repassadas, via Concessão de Direito Real de Uso (CDRU), quando couber e em caráter provisório, o que não desobriga o INCRA a outorgar o Título de Reconhecimento de Domínio no fim do processo.

\footnotetext{
Trata-se da obtenção dos imóveis e da retirada dos ocupantes não-quilombolas da área reivindicada pela comunidade tradicional, podendo os mesmos ser objeto de procedimento desapropriatório ou reassentados, caso se enquadrem no perfil do público atendido pelos critérios da reforma agrária.
} 


\section{6 - Solução de controvérsias e impasses institucionais}

Conforme demonstrado na seção anterior, a legislação prevê que as controvérsias institucionais no âmbito do processo de regularização das terras quilombolas deverão ser tratadas, se por questão de mérito, no âmbito da Casa Civil da Presidência da República; se por questão jurídica, será encaminhado à Câmara de Conciliação e Arbitragem da Administração Federal (CCAF), órgão da Consultoria-Geral da União - Advocacia-Geral da União.

Dentre esses instrumentos jurídicos que coordenam esses trabalhos, deve ser mencionado um manual publicado no âmbito da 6a Câmara de Coordenação e Revisão - Populações Indígenas e Comunidades Tradicionais (MPF), denominado Territórios de povos e comunidades tradicionais e as unidades de conservação de proteção integral: alternativas para o asseguramento de direitos socioambientais (2014). Esse documento foi elaborado com o propósito de servir como uma:

(...) sistematização de informações e na aplicação de sugestões práticas, baseadas na perspectiva da conciliação de interesses, visando apoiar a condução de procedimentos em que se verifique o enfrentamento do desafio de compatibilização de direitos. (MPF, 2014, p. 04).

No tópico 5.3 do referido manual, são elencados alguns subsídios para mediação de conflitos. Esses instrumentos podem ser combinados entre si, pois há possibilidade real de um complementar o outro.

O primeiro consiste na Criação de Câmaras Técnicas nos Conselhos Gestores das UC's. Trata-se da categorização dos conselhos de gestão da UC para que se aprofundem questões mais específicas como, por exemplo, o caso das populações do entorno e do interior dos da UC.

O segundo é o Plano de Uso Tradicional que, tal como mencionado pelo manual, trata-se de 
representantes dos povos e comunidades tradicionais e os órgãos gestores, composto por microzoneamento, regulamentação das atividades passíveis de realização em cada zona, lista de beneficiários e procedimentos de licenciamento (MPF, 2014, p.100).

Em seguida, o Manual trata das Zonas Histórico-Culturais Antropológicas, definidas por MPF (2014, p.101), como Zonas de Manejo Especial e contempla territórios:

(...) geograficamente espacializados, ocupados predominantemente por residentes definidos sob a categoria jurídica tradicional, nas quais é estabelecida a possibilidade de permanência desses ocupantes, sob determinados regimes de uso do território e dos recursos. São povos e comunidades tradicionais compondo vilas, ou bairros consolidados, constituídas anteriormente à criação da Unidade de Conservação, apresentando peculiaridades socioculturais. Podem ser criadas, inclusive, onde já há um território quilombola reconhecido.

MPF (2014) ressalta ainda que o Roteiro Metodológico de Planejamento do IBAMA prevê a aplicação desse instrumento com base nos artigos 215 e 216 da Constituição Federal, com vistas a assegurar a proteção e valorização dos aspectos imateriais, do patrimônio cultural desses povos.

Outro instrumento destacado pelo Manual são os Acordos de Gestão e de Manejo. Este instrumento é previsto na IN/ICMBio 29 de 05 de setembro de 2012, utilizado para disciplinar o uso de recursos naturais, da terra e convivência entre os moradores da UC.

É instrumento útil também nos casos de territórios tradicionalmente utilizados por comunidades tradicionais, mesmo em Unidades de Proteção Integral, para acelerar a formalização de regras e estabelecer o ordenamento do uso dos recursos e da terra, de modo a assegurar o acesso exclusivo das populações historicamente deles dependentes, como os povos e as comunidades tradicionais.

Por outro lado, o Manual destaca o Termo de Compromisso, que se trata de um acordo provisório que permite a utilização dos recursos da unidade e regulamenta a 
presença das comunidades na UC até que se encontre uma solução para o impasse, o que é previsto no Decreto no 4430 de 22 de agosto de 2002 e que foi normatizado pela IN/ICMBio no 26 de 04 de julho de 2012.

Outro instrumento destacado no Manual é a Dupla Afetação. É um regime que consiste na disponibilização de determinado imóvel a duas ou mais destinações de interesse público como, no caso em análise, das comunidades quilombolas e do PARNA.

Portanto, o regime de dupla afetação pressupõe uma administração conjunta do território ou bem destinado para que produza os efeitos esperados, razão pela qual as comunidades tradicionais interessadas bem como as instituições competentes, tais como a Funai, Ibama, ICMBio, Incra, FCP etc., deverão elaborar um Plano de Administração Conjunta do bem em questão, visando a compatibilização dos direitos fundamentais em jogo, observada a Convenção no 169 da OIT no tocante à necessidade de proceder-se à consulta livre, prévia e informada dos povos tradicionais em todas as fases do processo. (MPF, 2014, p. 106)

Nesse contexto, as comunidades tradicionais e os representantes das instituições interessadas elaboram um Plano de Administração conjunta do bem em questão.

Outro instrumento abordado pelo Manual é a possível Revisão dos limites de Unidades de Proteção Integral, apontada como uma saída para os casos em que a autonomia territorial da comunidade quilombola é uma condição para a busca de seu desenvolvimento social. O manual admite algumas situações em que esse expediente é visto pelas comunidades como a alternativa ideal, mas que pode representar, na verdade, numa maior fragilização das comunidades, uma vez que:

(...) em muitas situações, a depender da capacidade de governança instalada, ou seja, do fortalecimento e amadurecimento das comunidades para exercer a gestão dos territórios, bem como da sua capacidade de estabelecer alianças e de contar com rede de parceiros para apoio e interlocução, a retirada das Unidades de Conservação de sob seus territórios pode aumentar sua vulnerabilidade social e ambiental frente a forças de expansão econômica. (MPF, 2014, p.106)

A revisão dos limites da UC podem se dar, basicamente, a partir de três 
instrumentos principais. O primeiro é a recategorização, que consiste nas mudanças das categorias de manejo como, por exemplo, a Proteção Integral, para uma categoria compatível com a perpetuação do modo de vida das comunidades, que seria a categoria Uso Sustentável.

Requer o desenvolvimento de processo participativo de estudo, planejamento e negociação intensivo, assim como a manifestação explícita de interesse por parte dos povos tradicionais beneficiários. (MPF, 2014, p.107)

O segundo instrumento é a desafetação (tratado anteriormente), que consiste na redução da área ou até mesmo na "extinção" da Unidade de Conservação em proveito dos interesses das comunidades tradicionais. Ressalta-se, porém, que esse instrumento ocorrerá apenas por força de lei específica no Congresso Nacional, conforme previsto no Artigo 225 da Constituição Federal.

O terceiro e último instrumento no contexto da revisão dos limites da unidade de conservação é a criação dos Mosaicos de Unidades de Conservação, que fundamenta-se na recategorização e criação de novas UC's para compor territórios integrados de conservação, geridos na forma de Mosaicos, conforme previsto no Decreto Federal no 4.340/2002, que regulamenta o SNUC, Capítulo III. Essa iniciativa prevê mecanismos de gestão da presença humana, que consistem basicamente na Autorização de Uso para as comunidades tradicionais ou reassentamento dessas populações para UC's que compõem o mesmo Mosaico, mas que permitam o uso sustentável.

O Manual destaca ainda a Câmara de Conciliação e Arbitragem da AdvocaciaGeral da União (CCAF) como um instrumento para resolução destes impasses. Conforme discutido anteriormente, a CCAF é um instrumento criado no âmbito do Poder Executivo, para buscar conciliar os interesses dos atores políticos institucionais ou, quando a conciliação não é possível, proceder o arbitramento da controvérsia. MPF (2014, p. 109) ressalta ainda que 
federais envolvendo a consecução de políticas públicas para a realização de direitos fundamentais, muitas delas relativas à sobreposição de territórios tradicionais, quilombolas e outros - com Unidades de Conservação Ambiental. Isso porque é sabido que, em grande escala, principalmente na região Norte do Brasil, essas populações têm seus territórios tradicionais no todo ou em parte coincidentes com áreas ambientalmente especialmente protegidas, o que não constitui mera coincidência. A maior parte dos territórios ocupados por populações tradicionais está razoavelmente preservada em decorrência, justamente, de seu especial modo de vida, que exerce menor pressão sobre os recursos naturais. No entanto, e apesar dessa especial relação que historicamente mantêm os povos tradicionais com a natureza, são inúmeros os conflitos gerados pelas sobreposições entre territórios tradicionais e, especialmente, as Unidades de Conservação da natureza de Proteção Integral, cuja presença humana tem sido apenas tolerada em condições excepcionais pela maioria dos gestores ambientais, tanto em âmbito federal quanto estadual.

Esse dispositivo vem recebendo muitas críticas relativas à falta de resultados práticos, ou seja, a não produção de concílios ou de arbitragem e a consequente perpetuação de controvérsias institucionais e de conflitos fundiários, envolvendo as comunidades tradicionais. Outra questão que levanta críticas é o fato de não haver previsão regimental no âmbito da CCAF, para que as comunidades interessadas possam se manifestar nesses espaços, conforme explicita MPF (2014, p. 109):

Visando melhorar a eficiência da atuação da CCAF, o Ministério Público Federal, por meio do GT Quilombos, Povos e Comunidades

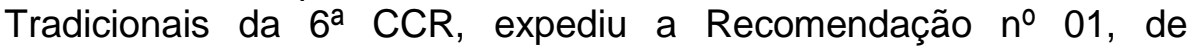
24/10/2012, ao Senhor Consultor-Geral da União para que promova a conciliação ou, quando não cabível, a arbitragem das controvérsias entre órgãos e entidades públicas federais submetidas à CCAF, em 180 dias no que tange à consecução de políticas públicas para a realização de direitos fundamentais, a maioria envolvendo sobreposições de territórios tradicionais e Unidades de Conservação. Outra preocupação a ser observada pelo MPF é quanto à garantia de participação de representantes dos povos tradicionais nas reuniões da CCAF nos casos que lhes digam respeito, o que não tem ocorrido por falta de previsão regimental, em total afronta ao direito de Consulta Livre, Prévia e Informada prevista na Convenção no 169 da OIT. 
Artigo 68 do ADCT, verifica-se que não são todos os instrumentos citados que atendem o preceito constitucional da titulação das terras quilombolas. $O$ texto constitucional é claro em estabelecer que "Aos remanescentes das comunidades dos quilombos que estejam ocupando suas terras é reconhecida a propriedade definitiva, devendo o Estado emitir-Ihes os títulos respectivos".

Em nosso entendimento, qualquer instrumento que não conduza à garantia da segurança fundiária via emissão dos títulos de domínio às comunidades tradicionais quilombolas será um instrumento precário, paliativo ou, se chegar a propor uma saída alternativa e de carácter permanente que não contemple a emissão dos respectivos títulos estará necessariamente em desacordo com o estabelecido pela Carta Magna.

Não se trata, entretanto, de negar à legítima autoridade ambiental a tarefa constitucionalmente consagrada de estabelecer, em conjunto com as comunidades envolvidas, o regramento para o manejo sustentável dos recursos ambientais e de proteção a espécies e/ou ambientes/habitats especiais por ventura situados nos limites do território pleiteado. Contudo, não há espaço para negociações quanto ao dever da União em emitir os títulos referentes às áreas que as comunidades ocupam atualmente e também àquelas que comprovadamente ocupavam em 05 de outubro de 1988 e que, por causas relacionadas à ineficiência, ação ou omissão do poder público em atender essas populações em seus direitos básicos, como educação, saneamento, saúde, segurança etc., encontraram como alternativa a negociação de glebas do território ou a fuga para outras regiões em busca de dignidade e condições mínimas de reprodução e sobrevivência.

O instrumento da Dupla Afetação é característico do caso que envolve o PARNA do Monte Roraima (criado em 1989) e a Terra Indígena Raposa Serra do Sol, situação em que o primeiro está integralmente sobreposto ao segundo e que se encontrou, na Dupla Afetação, um expediente que prevê a preservação do meio ambiente e a realização dos direitos constitucionais dos índios, além de estabelecer um arranjo de gestão compartilhada para administração da área, elaborado em conjunto com a comunidade indígena Ingarikó. 


\title{
CAPÍTULO IV: Titulação das terras quilombolas: análise de processo e de impacto
}

\begin{abstract}
A realização de uma análise de processo e de impacto das ações de regularização das terras quilombolas é compreendida no âmbito deste trabalho como prerrogativa para a identificação e interpretação dos fatores geopolíticos determinantes para o fracasso dessas ações no Brasil e constitui-se como o objetivo deste capítulo. Será demonstrado, a partir da análise e espacialização dos resultados das ações de territórios quilombolas no Brasil nos diferentes recortes temporais que, à medida que as ações foram impactando os interesses territoriais e políticos dos seus grupos de sustentação, "quem governa" fundou novos paradigmas não apenas para identificar a oportunidade e conveniência administrativa em relação aos pleitos das comunidades quilombolas, mas também reformou preceitos metodológicos com vistas à restrição das áreas a serem reconhecidas como materialização das territorialidades desses grupos étnicos tradicionais. Isso acabou por representar, portanto, na re-delimitação de seus próprios direitos e de sua posição estratégica na participação da agenda social e política do Governo.
\end{abstract}

\section{1 - Análise de processo e de impacto: os resultados das ações de territórios quilombolas no Brasil}

A produção científica, em torno da problemática quilombola, se consolida exponencialmente nas últimas décadas. Para que se compreenda a relevância do tema para a comunidade científica, uma pesquisa ao banco de teses e dissertações da Universidade de São Paulo no dia 13 de abril de 2017, identificou 49 dissertações de mestrado e 50 teses de doutorado que continham a expressão "quilombo" em seus títulos, palavras-chave ou resumos (abstract). São pesquisas que abarcam diversos campos da ciência, como a Genética, Filologia e Língua Portuguesa, Educação, Psicologia Social, Enfermagem em Saúde Pública, Ecologia Aplicada, 
Medicina Preventiva, Arqueologia, História Social, Antropologia Social e a Geografia, o que demonstra um notável interesse acadêmico e social pela compreensão dos processos e fenômenos, que envolvem essas comunidades tradicionais afrodescendentes.

A respeito do tema específico da regularização ou titulação das terras quilombolas, percebe-se que este tem merecido amplo destaque nos estudos desenvolvidos no âmbito das Ciências Humanas e do Direito. Nesse contexto, destacamos as contribuições de Leite (2005), Arruti (2003, 2009), Treccani (2006), Fiabani $(2005,2012,2013)$, bem como as séries de boletins publicados pelo Instituto de Estudos Sócioeconômicos (INESC), que são referências indispensáveis para a análise do tema proposto. Contudo, há que se ressaltar que, não raro, esses trabalhos são marcados pela interdisciplinariedade de suas abordagens, reflexo da complexa teia de relações e interesses políticos e sociais envolvidos na garantia desses direitos fundamentais da pessoa humana.

Neste contexto, realizaremos, num primeiro momento, a análise de impacto das ações de titulação, abordando variáveis como número de famílias beneficiadas, área titulada e número de títulos outorgados e, em seguida, partiremos para a confrontação desses dados com a trajetória orçamentária e financeira dessas ações (a partir de 2004), analisando a trajetória de recursos planejados, autorizados e efetivamente utilizados (pagos).

O Programa Brasil Quilombola (PBQ) acolheu as ações de titulação de terras quilombolas nos PPA's de 2004-07 e de 2008-11. Estruturou-se a partir de 04 eixos fundamentais: Eixo 01: Acesso à Terra; Eixo 02: Infraestrutura e Qualidade de Vida; Eixo 03: Desenvolvimento Local e Inclusão Produtiva; Eixo 04: Direitos e Cidadania. Apesar de reconhecer a importância estratégica de todos esses temas para a qualidade de vida e dignidade das populações tradicionais, o contexto de pesquisa desse trabalho nos obriga a delimitar nossa análise sobre os fenômenos, que guardam relação direta com o Eixo 01, pois é nele que estão concentradas as ações de titulação das terras quilombolas.

Eixo 1: ACESSO A TERRA - execução e acompanhamento dos trâmites necessários para a regularização fundiária das áreas de quilombo, que constituem título coletivo de posse das terras 
tradicionalmente ocupadas. $O$ processo se inicia com a certificação das comunidades e se encerra na titulação, que é a base para a implementação de alternativas de desenvolvimento para as comunidades, além de garantir a sua reprodução física, social e cultural.

Dados oficiais disponibilizados pela Coordenação de Regularização de Territórios Quilombolas (DFQ/INCRA) no sítio oficial da autarquia, informam que, desde $\mathrm{o}$ advento da titulação de terras quilombolas como um direito constitucional (atualizados em 05 de abril de 2017), foram expedidos pelo INCRA, FCP e diversos órgãos estaduais 220 títulos em 152 territórios, beneficiando 294 comunidades e titulando $1.110 .519,5733$ ha. Deste montante, porém, apenas $776.801,7590$ ha foram efetivamente destinados às comunidades tradicionais, uma vez que algumas áreas tituladas pela FCP ainda não sofreram os procedimentos de desintrusão e destinação das áreas às famílias quilombolas, restando ao INCRA regularizar esse passivo, ou seja, são áreas tituladas, mas não se encontram na posse dos quilombolas. As áreas que foram tituladas e efetivamente destinadas às comunidades quilombolas são demonstradas no Quadro 05:

\begin{tabular}{|c|c|c|}
\hline Órgão Expedidor & Área Destinada (ha) & \% por Órgão \\
\hline ITERPA/ PA & $483.932,6659$ & 62,30 \\
\hline INCRA & $\mathbf{1 5 8 . 7 6 1 , 8 4 5 2}$ & $\mathbf{2 0 , 4 4}$ \\
\hline ITERMA/MA & $30.171,9512$ & 3,88 \\
\hline ITERBA e CDA / BA & $29.350,8033$ & 3,78 \\
\hline FCP & $24.105,2081$ & 3,10 \\
\hline ITERPI/PI & $20.497,6071$ & 2,64 \\
\hline ITESP/SP & $18.828,1157$ & 2,42 \\
\hline SPU & $9.580,3384$ & 1,23 \\
\hline
\end{tabular}




\begin{tabular}{|c|c|c|}
\hline CEMIG & $1.121,4200$ & 0,14 \\
\hline SEHAF e ITERJ/RJ & 378,4864 & 0,05 \\
\hline IDATERRA/MS & 73,3177 & 0,01 \\
\hline
\end{tabular}

Quadro 05: Áreas tituladas efetivamente destinadas às comunidades tradicionais quilombolas: 1995 a 2017. Fonte: DFQ/INCRA; Adaptado pelo autor.

A localização das comunidades que tiveram suas terras tituladas pelo INCRA nesse período está disposta na Figura 04:

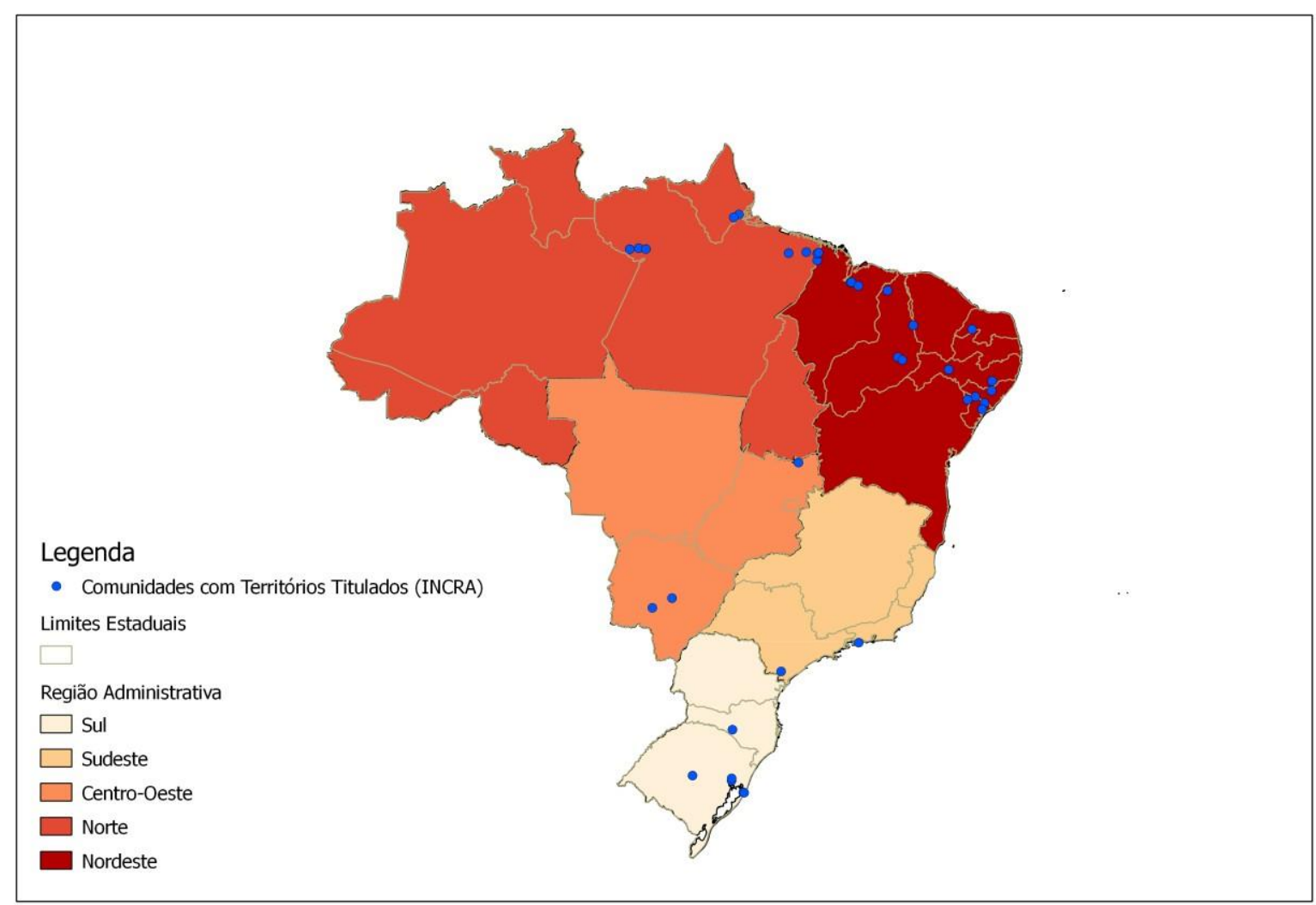

Figura 04: Localização das Comunidades Tradicionais Quilombolas com Território Titulado pelo INCRA: 1995 a 2017. Fonte: Acervo Fundiário do INCRA. Organizado pelo Autor.

Porém, é necessário ressaltar que, devido às dificuldades de se obterem dados de demanda e informações orçamentárias e, principalmente, financeiras, sistematizadas e confiáveis entre os exercícios de 1995 (data do primeiro título expedido pelo INCRA) e 2003, nossa análise sofreu um recorte temporal que 
restringe esse tipo de análise a partir do exercício de 2004, pois, é somente a partir desse exercício, que o INCRA tem dados de demanda e de recursos orçamentários e financeiros organizados de forma sistematizada e confiável. Devido a essas limitações, optamos por balizar a análise da trajetória financeira e orçamentária das ações de titulação das terras quilombolas, a partir da publicação do Decreto 4.887 de novembro de 2003, que teve efeitos práticos apenas no exercício seguinte, 2004, estendendo nossa análise até o encerramento do PPA 2012-15, como forma de conferir parâmetros de comparação coerentes.

$\mathrm{Na}$ análise de impacto (resultados), ou seja, no número de famílias beneficiadas, área titulada e títulos emitidos, foram levantados dados sistematizados e confiáveis desde 1995 a 2015, o que nos permitiu, por exemplo, comparar as ações de titulação das terras quilombolas no período pré e pós-decreto 4.887, assim como os produtos e resultados obtidos pelo INCRA com aqueles obtidos pelos órgãos estaduais e, estabelecer assim, diversas abordagens comparativas. Em síntese, nossa reflexão se dará a partir dos dados referentes a:

- Evolução da demanda (número de processos no INCRA), disponível para consulta no sítio oficial da FCP e do INCRA e organizados pelo autor, de 2003 a 2015;

- Recursos orçamentários e financeiros destinados a essas ações, gentilmente cedidos pela Coordenação de Regularização de Territórios Quilombolas do INCRA, em Brasília e organizados pelo autor, de 2004 a 2015;

- Dos resultados tangíveis (quantidade de títulos emitidos, número de famílias beneficiadas, área titulada), disponíveis para consulta no sítio oficial da FCP e do INCRA e organizados pelo autor, de 2004 a 2015;

- Espacialização dos resultados tangíveis alcançados pelo INCRA (regiões administrativas), disponíveis para consulta no sítio oficial da FCP e do INCRA e organizados pelo autor;

- Identificação dos gargalos e entraves político-institucionais, estruturais e jurídicos que influenciam a execução dessas ações. 


\section{2 - Titulação de Terras Quilombolas de 1995 a 2003: a fase Pré-Decreto 4.887 de 2003}

Conforme exposto no Capítulo III, a primeira emissão de título de domínio para uma comunidade quilombola se deu em 1995, pelo INCRA, com fundamento na Portaria INCRA ํo 307 de 22 de novembro de 1995, beneficiando a Comunidade Boa Vista, composta por 112 famílias, localizada no munícipio de Oriximiná - PA. Foram demarcados 1.125,0341 ha, desmembrados de uma Gleba de terras públicas denominada Trombetas.

Esse foi o marco para o início de uma fase aqui denominada como PréDecreto 4.887 de 2003, marcada pela indefinição de qual órgão federal encamparia a atribuição pelas ações de titulação das terras quilombolas, assim como das primeiras tentativas de regulamentação do Artigo 68 do ADCT.

Nesse contexto, a fase Pré-Decreto 4.887 pode ainda ser subdivida em dois momentos. O primeiro compreende os anos de 1995 a 1999, em que o INCRA outorgou 07 títulos, conforme demonstrado no Capítulo III por Treccani (2005), onde chamou atenção para a ressalva de que os trabalhos do INCRA foram facilitados pelo fato dessas terras estarem localizadas em glebas públicas arrecadadas e matriculadas em nome da União pelo órgão.

O segundo momento do período Pré-Decreto 4.887 compreende os anos de 1999 a 2003, que é o período em que esteve em vigor a Medida Provisória 1.911 de 29 de Julho de 1.999, que definiu a atribuição de titulação das terras quilombolas à FCP.

De 1.999 a 2003, período em que a FCP monopolizou tal atribuição em âmbito federal, foram emitidos 18 títulos, curiosamente, todos outorgados num único ato da Presidente da FCP, publicado no DOU de 18 de julho de 2000. Os títulos emitidos pela FCP estão disponíveis no Quadro 06. 


\begin{tabular}{|c|c|c|c|}
\hline Comunidade & Município & UF & Área titulada (ha) \\
\hline Itamoari & Cachoeira do Piriá & PA & $5.377,6020$ \\
\hline Mangal & Sítio do Mato & BA & 153,8043 \\
\hline Campinho da Independência & Paraty & RJ & 287,9461 \\
\hline Curiaú & Macapá & AP & $3.268,9400$ \\
\hline Barra, Bananal e Riacho das Pedras & Rio de Contas & BA & $1.339,2768$ \\
\hline $\begin{array}{l}\text { São José, Matá, Cuecé, Apui, } \\
\text { Silêncio, Castanhanduba, }\end{array}$ & Óbidos & PA & $17.189,6939$ \\
\hline Porto Coris & Leme do Prado & MG & 199,3001 \\
\hline Kalunga & $\begin{array}{l}\text { Monte Alegre, Teresina } \\
\text { e Cavalcante }\end{array}$ & GO & $253.191,7200$ \\
\hline Mocambo & Porto da Folha & SE & $2.100,5400$ \\
\hline Rio das Rãs & Bom Jesus da Lapa & $\mathrm{BA}$ & $27.200,0000$ \\
\hline Ivaporanduva & Eldorado & SP & $3.158,1100$ \\
\hline Furnas do Dionísio & Jaraguarí & MS & $1.031,8905$ \\
\hline Furnas da Boa Sorte & Corguinho & MS & $1.402,3927$ \\
\hline Santana & Quatis & RJ & 828,1200 \\
\hline Mangal/Barro Vermelho & Sítio do Mato & BA & $7.615,1641$ \\
\hline Castainho & Guaranhuns & PE & 163,6000 \\
\hline Mata Cavalo & N. Sra. Livramento & MT & $11.722,4613$ \\
\hline Conceição das Crioulas & Salgueiro & PE & $16.865,0678$ \\
\hline
\end{tabular}

Quadro 06: Títulos outorgados pela FCP (1999 a 2003). Fonte: DOU: 18 de julho de 2000.

Dentre as comunidades tituladas pela FCP, em apenas 05 , ocorreram os procedimentos de desintrusão e entrega do território para as comunidades. Foram efetivamente realizadas pela FCP, a saber: Mangal e Barro Vermelho (BA), Curiaú (AP), Barra e Bananal (BA), São José, Silêncio, Mata, Cuecê, Apui e Castanhaduba (PA) e Rio das Rãs (BA). Os procedimentos para desintrusão e destinação das terras às famílias quilombolas das comunidades restantes estão sendo realizados 
pelo INCRA, desde a vigência do Decreto 4.887 de 2003, à exceção da comunidade de Ivaporunduva (SP), que teve a desintrusão e destinação das terras realizadas pela Fundação Instituto de Terras do Estado de São Paulo (ITESP).

Entre 1995 e 20037', o INCRA foi responsável por 11,2\% das terras quilombolas tituladas no Brasil (96.100 dos 859.082,3 ha), concentrando sua atuação exclusivamente na região Norte, onde foi responsável por $17,8 \%$ das titulações ocorridas naquele período.

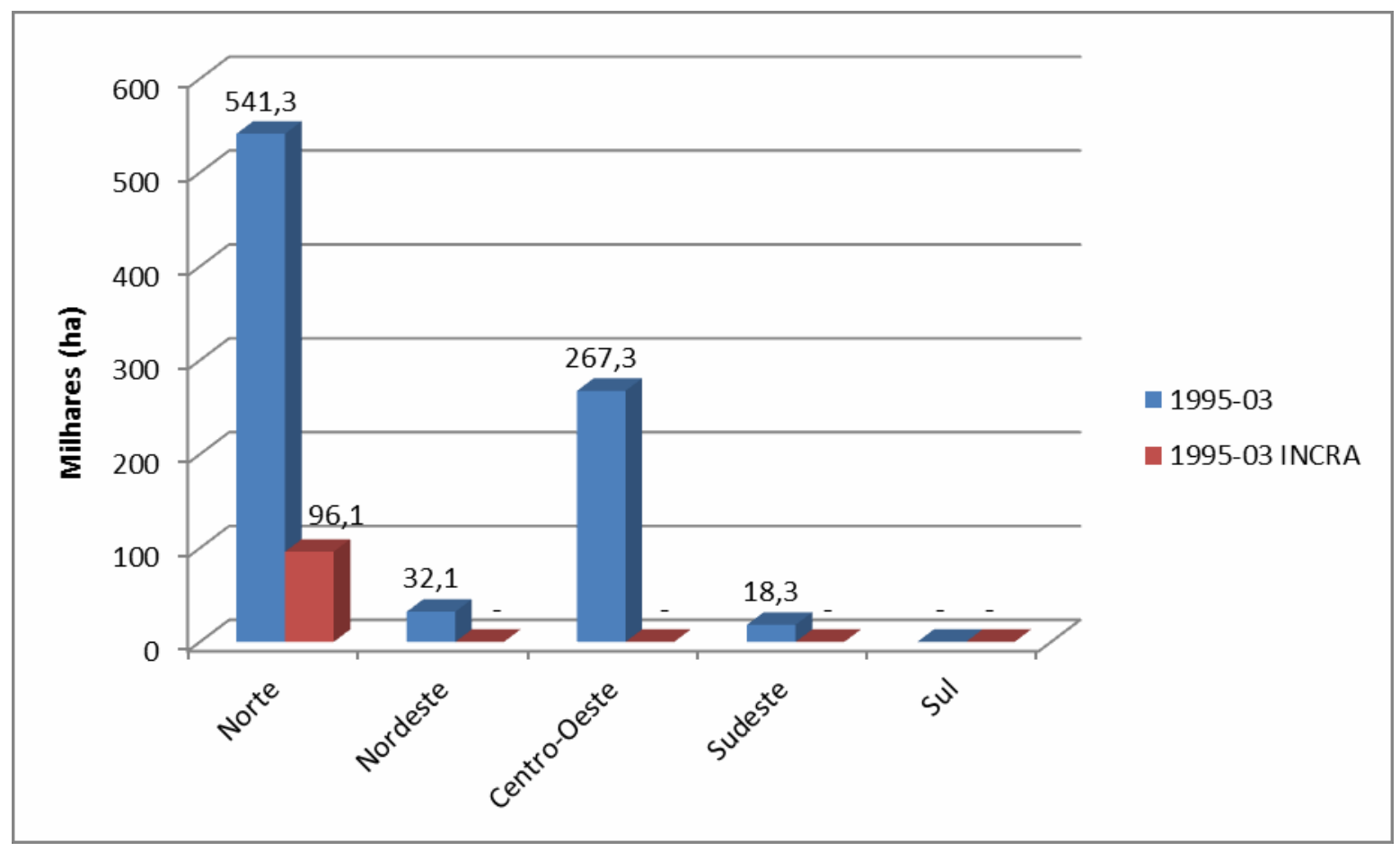

Gráfico 01: Distribuição regional das terras tituladas - Brasil: 1995 a 2003. Fonte: INCRA/DFQ. Organizado pelo autor.

De acordo com os dados contidos na Gráfico 01, nota-se também que as ações de titulação das terras quilombolas, independentemente, se executadas por órgãos federais ou estaduais, concentraram-se basicamente nos estados da região Norte e Centro-Oeste. As regiões, com demandas mais expressivas, como Nordeste e Sudeste apresentaram resultados proporcionalmente bem inferiores, enquanto que na região Sul nenhum hectare de terra quilombola fora titulado.

\footnotetext{
7 Como dito anteriormente, entre julho de 1999 e novembro de 2003 as atribuições para titulação das terras quilombolas foram atribuídas exclusivamente à FCP. Contudo, optamos por considerar os dados dos resultados obtidos pelo INCRA no período 1995 a 2003 por considerar mais conveniente para a organização das informações estatísticas e para entendimento do processo como um todo, por ser o período "Pré-Decreto 4887".
} 


\section{3 - A Fase Pós-Decreto 4887 de Novembro de 2003}

Conforme discutido anteriormente, com a publicação do Decreto 4.883 e 4.887 de novembro de 2003 , as atribuições para titulação de terras quilombolas em âmbito federal foram transferidas da FCP ao INCRA. Desde a publicação do Decreto 4.887, em 2003 até o fim de 2015, foram iniciados 1.536 processos administrativos de regularização de territórios quilombolas. No âmbito desse capítulo, abordaremos, no entanto, apenas os processos iniciados a partir de 2004, para que as análises orçamentárias e financeiras possam coincidir com os PPA's do período "Pós-Decreto 4.887", no sentido de facilitar a organização dos dados e a compreensão dos processos identificados, haja vista que no ano de 2003 apenas 09 processos foram iniciados. O Gráfico 02 fornece a distribuição desses processos no INCRA por PPA:

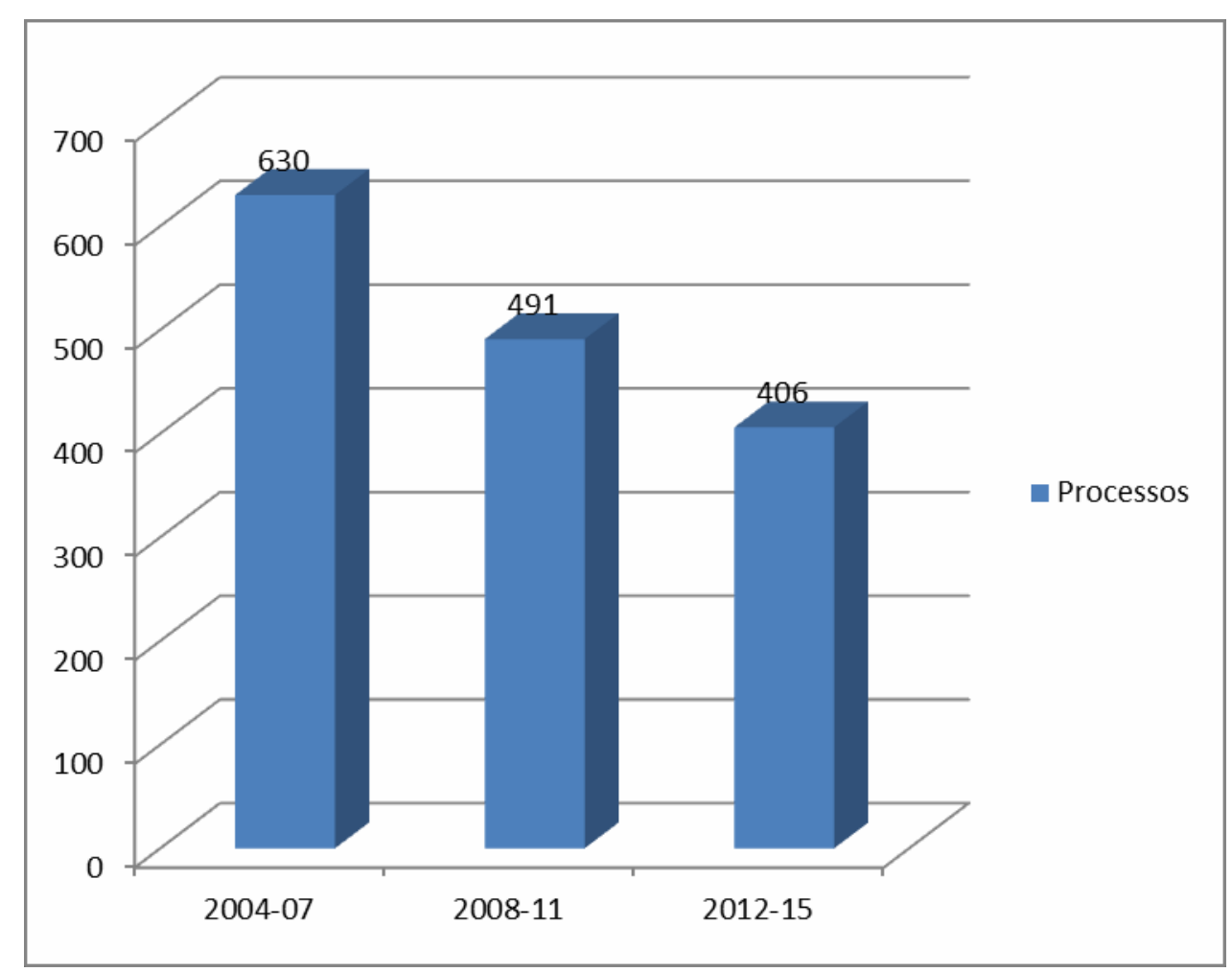

Gráfico 02: INCRA - Processos quilombolas iniciados por PPA - 2004 a 2015. Fonte: INCRA/DFQ. Adaptado pelo autor.

Do universo de 1.527 processos iniciados no decorrer dos 03 PPA's abordados, observa-se que 1.318 (ou 85,8\%) não contam sequer com o RTID 
publicado, ou seja, não alcançaram sequer a primeira etapa/fase do processo de regularização do território quilombola, conforme preconizado pela IN/INCRA 57 de 2009.

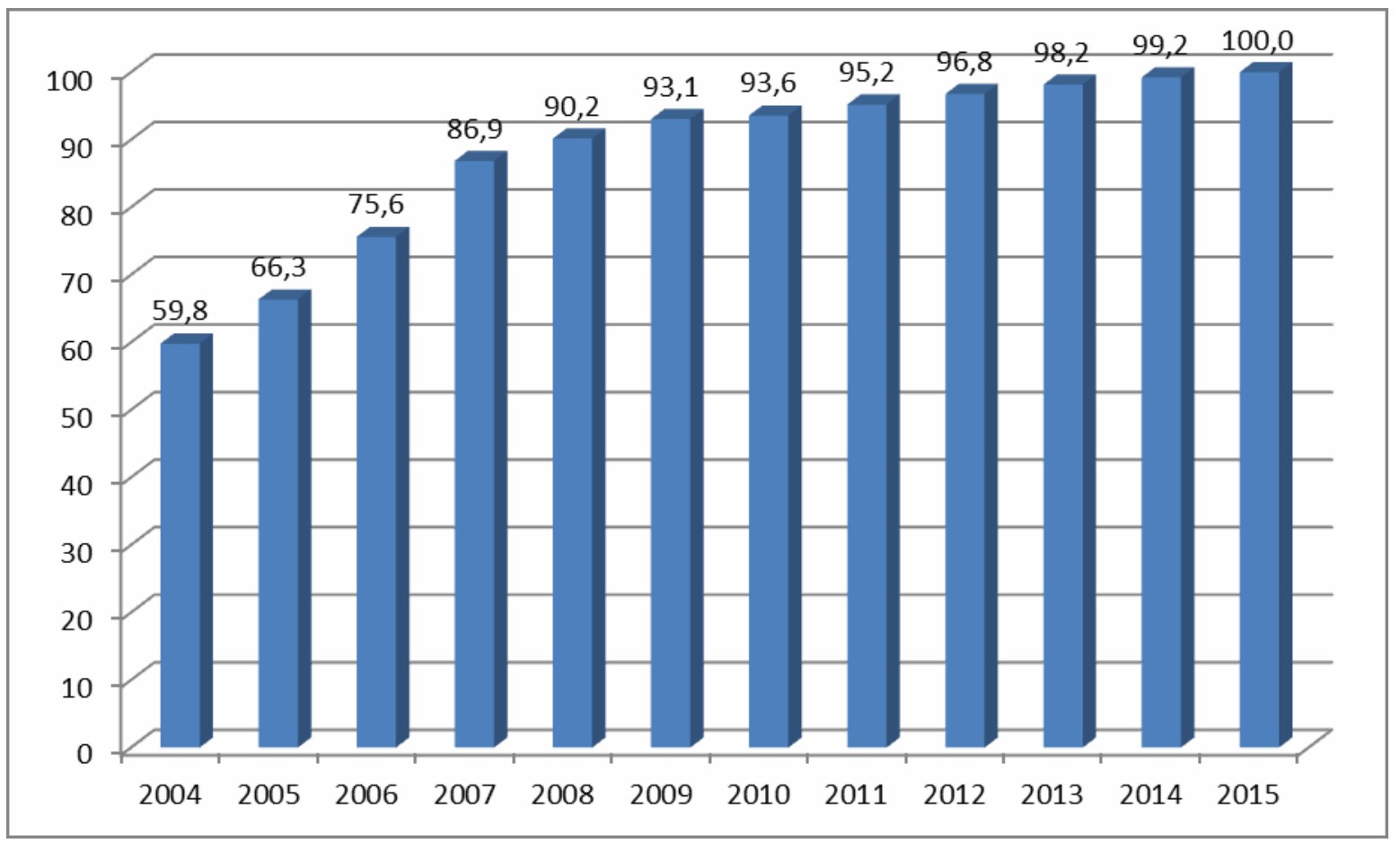

Gráfico 03: INCRA: Proporção de processos quilombolas sem RTID (\%): 2004 a 2015. Fonte: DFQ/INCRA. Adaptado pelo Autor.

Os dados contidos no Gráfico 03 revelam, por exemplo, que quase 60\% dos processos iniciados no INCRA em 2004 ainda se encontram sem instrução efetiva. Como é o primeiro ano/exercício completo das ações de titulação de terras quilombolas no INCRA, é natural que apresentasse uma taxa de instrução processual mais elevado. Contudo, $40 \%$ de processos, sem nenhum tipo de avanço processual efetivo, é uma proporção que consideramos muito elevada, haja vista que se passaram 12 exercícios desde sua formalização na autarquia, período mais do que suficiente para que essa proporção fosse bem menor.

Quando se organiza esses dados por PPA, a proporção de processos não instruídos é ainda mais crítica á medida que os exercícios mais recentes são considerados na análise. Esses dados são demonstrados no Gráfico 04, a seguir: 


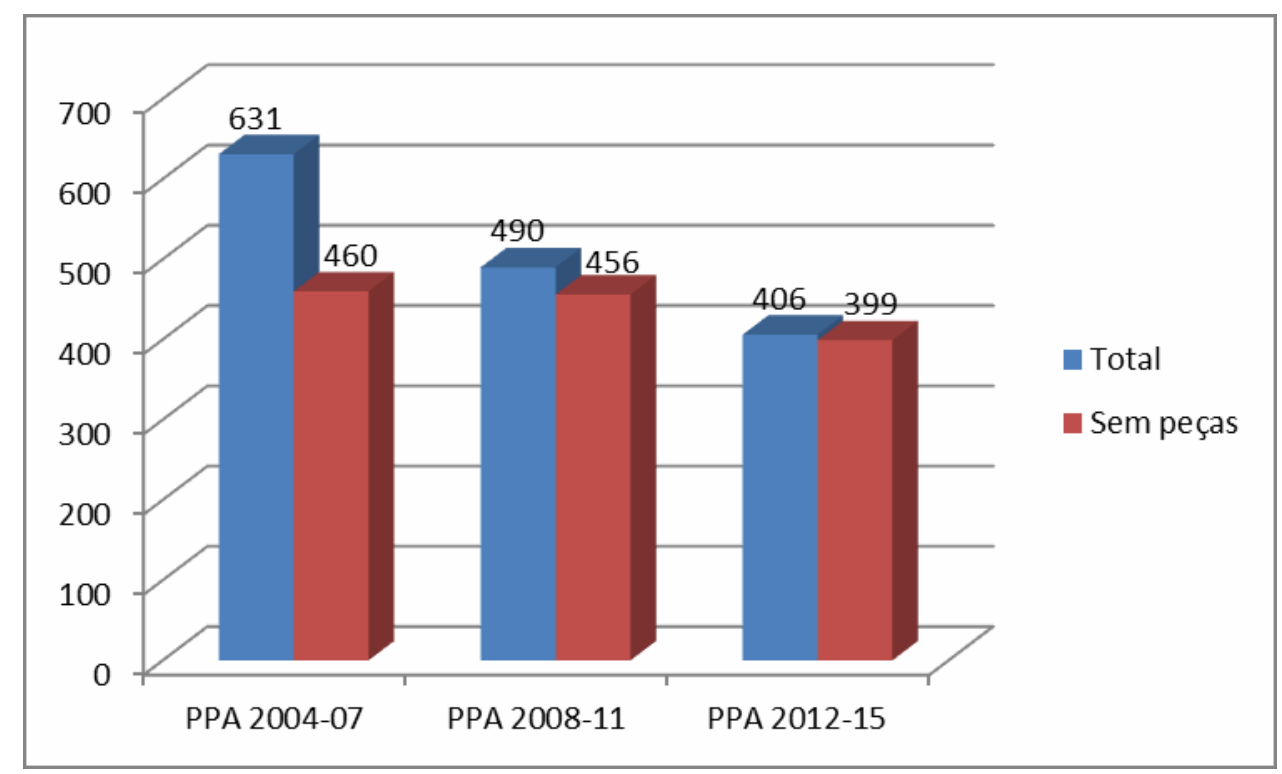

Gráfico 04: INCRA: Total de processos iniciados e processos sem nenhuma instrução, por PPA. Fonte: DFQ/INCRA. Adaptado pelo autor.

Neste contexto, o PPA 2004-07 é aquele que apresenta o maior número absoluto de processos não finalizados: são 102 processos de 2004, 204 de 2005, 164 de 2006 e 160 de 2007. O Gráfico 05, a seguir, apresenta a situação do andamento desses processos distribuídos em 07 categorias: RTID, Portaria da Presidência do INCRA, Decreto da Presidência da República, CDRU, Titulação Parcial, Titulação Total e, por fim, sem peças técnicas elaboradas. 


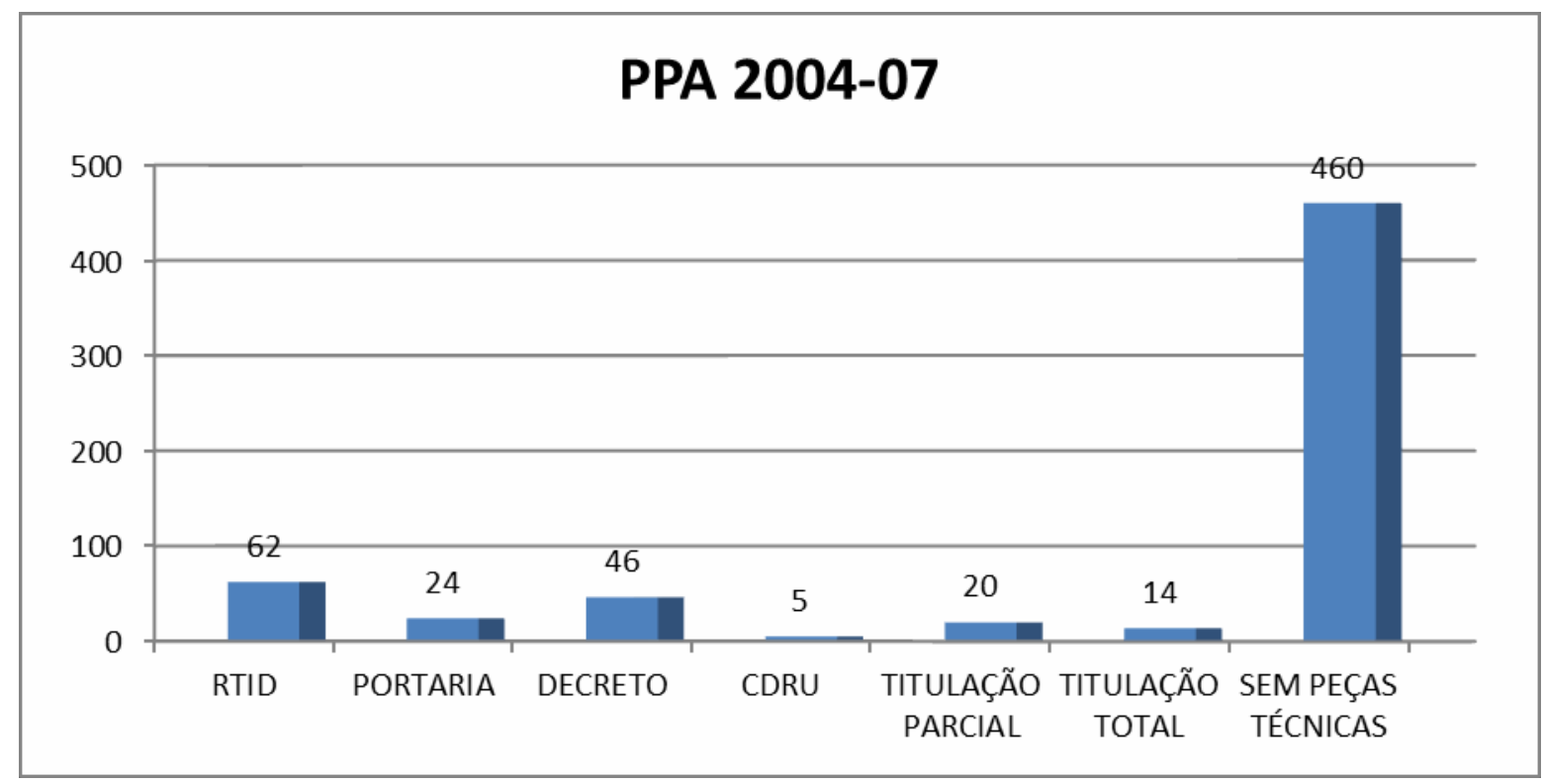

Gráfico 05: INCRA: Processos quilombolas por fase de instrução, 2004 a 2007. Fonte: DFQ/INCRA. Adaptado pelo Autor.

Observa-se que dos 631 processos de regularização de territórios quilombolas, iniciados no PPA 2004-07, a maior parcela $(72,9 \%)$ ainda não tem sequer o RTID publicado; apenas 14 alcançaram a titulação total das terras reivindicadas, enquanto 20 alcançaram titulação parcial e 05 contam com CDRU. Outros 46 processos contam com decretos da Presidência da República e outros 24 com portaria da Presidência do INCRA, enquanto que 62 se encontram com o RTID publicado. Por se tratar do PPA mais antigo, esses números se tornam ainda mais preocupantes, pois tratam das demandas que se arrastam há mais tempo e que, portanto, se espera resultados efetivos em proporções mais robustas.

Outro aspecto relevante a ser observado nesses números, refere-se à distribuição regional dos processos do PPA 2004-07 que ainda não avançaram nem mesmo à publicação do RTID. Os números fornecidos revelam que 41,9 \% dessa demanda reprimida está localizada nos estados da região Nordeste; $24,4 \%$ na região Sudeste; $16,8 \%$ na região Centro-Oeste, enquanto que 9,9\% desses processos estão localizados na região Norte e 7,0\% na região Sul. Os estados que apresentam a maior concentração desses processos não instruídos são Maranhão (131), Minas Gerais (74) e Mato Grosso (64).

No que se refere ao PPA 2008-11, observa-se que, dos 490 processos 
iniciados, nenhum alcançou a titulação total e, apenas, 01 alcançou a titulação parcial. Foi emitida $01 \mathrm{CDRU}$ e 07 decretos presidenciais foram assinados, conforme demonstra o Gráfico 06, a seguir:

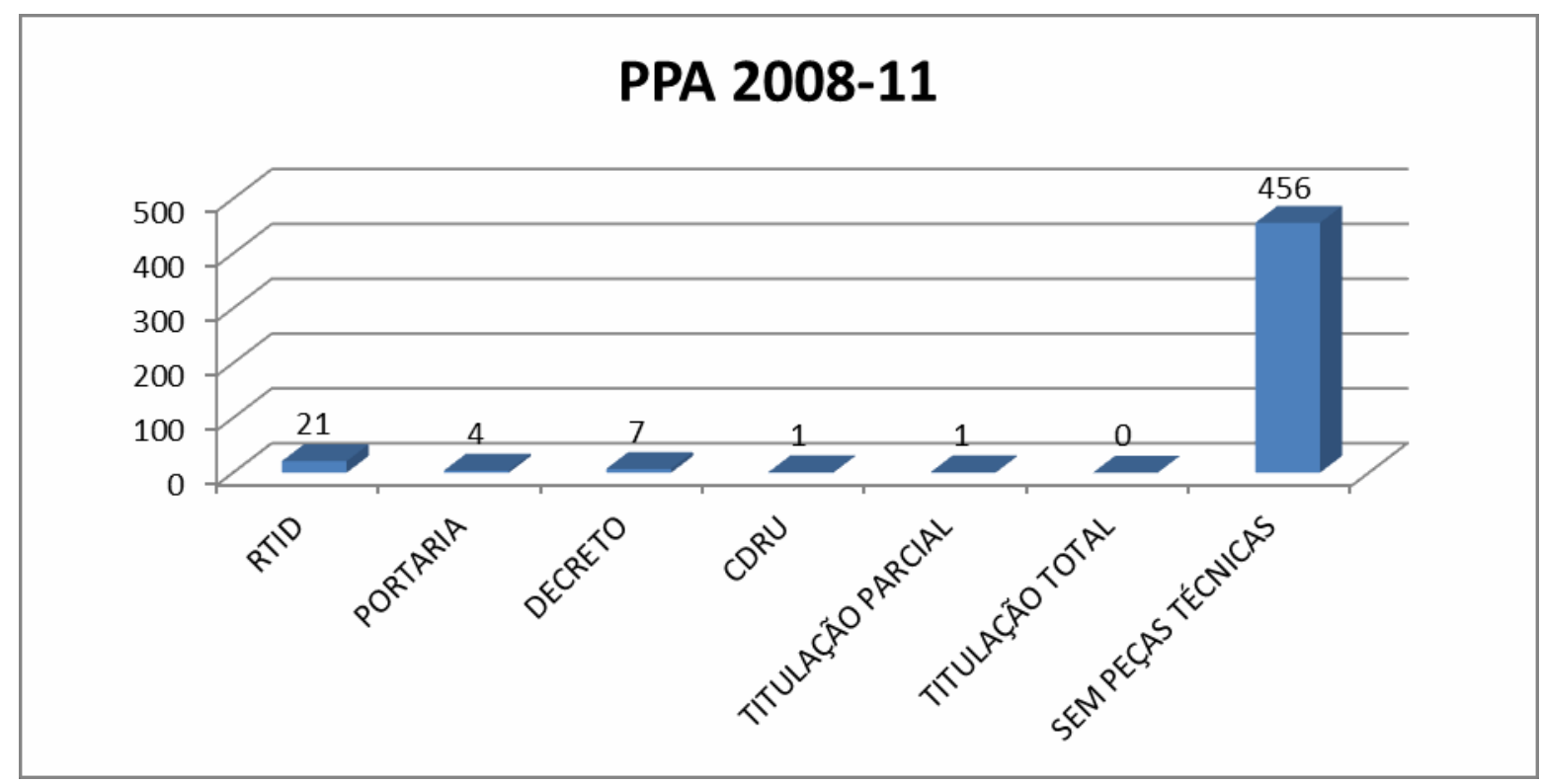

Gráfico 06: INCRA: Processos quilombolas por fase de instrução, 2008 a 2011. Fonte: DFQ/INCRA. Adaptado pelo Autor.

Desse período, foram expedidas 04 portarias de reconhecimento da Presidência do INCRA e apenas 21 RTID's foram publicados. Dessa forma, 456 processos $(93,1 \%)$ não têm sequer o RTID publicado.

A situação dos processos quilombolas iniciados no PPA 2012-15 é ainda mais crítica do que se comparada aos PPA's anteriores: apenas 05 desses processos têm RTID's publicados e apenas 02 decretos foram expedidos. 


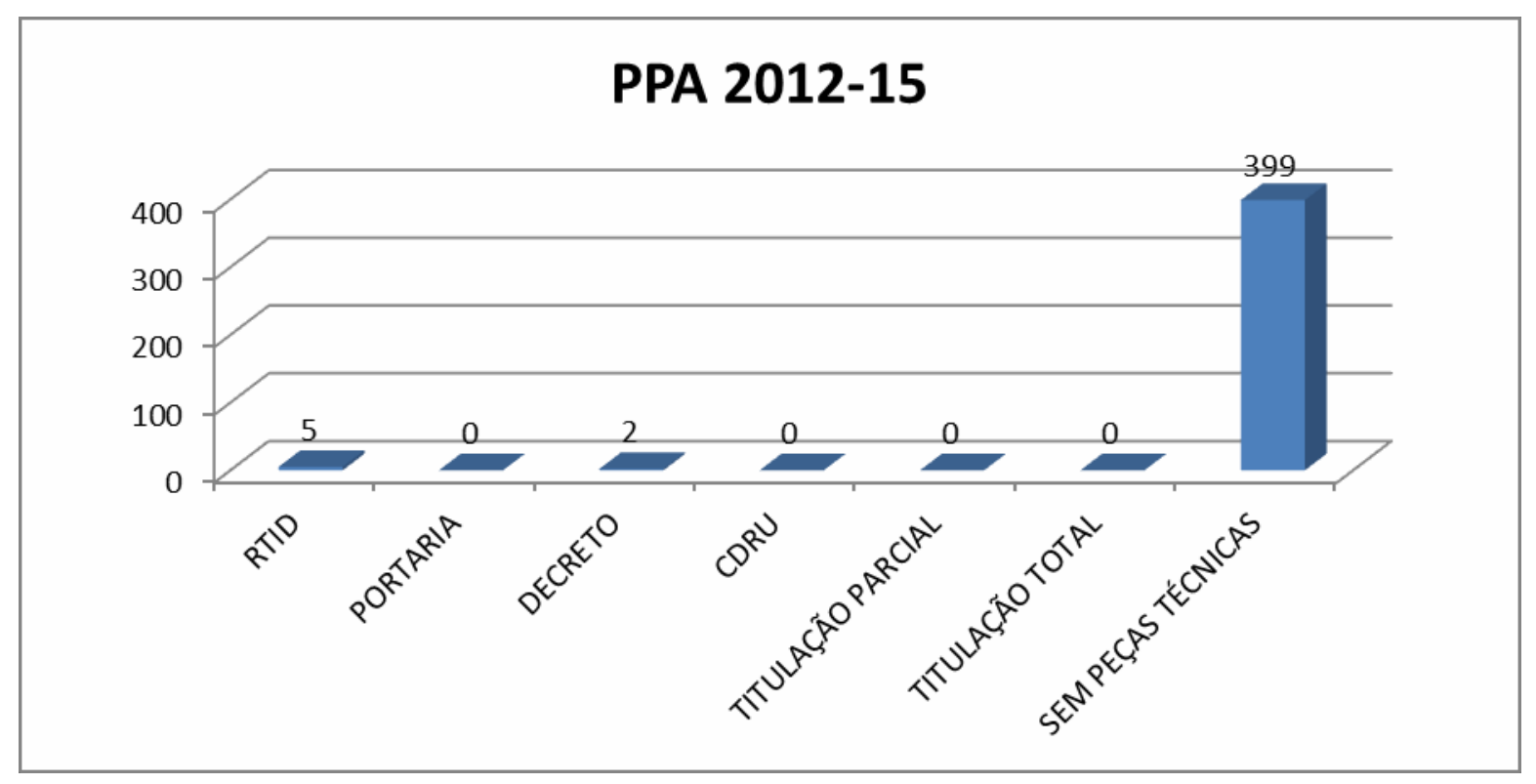

Gráfico 07: INCRA: Processos quilombolas por fase de instrução, 2012 a 2015. Fonte: DFQ/INCRA. Adaptado pelo Autor.

Significa, portanto, que 98,3\% dos processos iniciados, nesse período, não contam com qualquer tipo de fase concluída. Há de se considerar, porém, que se tratam de processos administrativos mais recentes e que, pela lógica administrativa e burocrática a que estão inseridos, espera-se que realmente alcancem resultados inferiores aos PPA's mais antigos. Porém, mesmo com essa ressalva, nota-se que a proporção da demanda "não instruída" pelo INCRA está longe dos padrões de eficiência e eficácia instituídos pelo princípio da eficiência na administração pública.

No que se refere à distribuição regional das terras tituladas e famílias beneficiadas, optou-se por compartimentar os dados, a partir dos Planos PluriAnuais - PPA's, para que fosse possível estabelecer sua correlação com os dados de planejamento orçamentário e de execução financeira, que debateremos em seção específica.

Os Gráficos 08, 10 e 11 demonstram os montantes de terras quilombolas tituladas regionalizadas e por PPA (2004-07, 2008-11 e 2012-15), além de comparar os resultados obtidos pelo INCRA em relação aos alcançados pelos órgãos estaduais de terras $^{8}$.

\footnotetext{
$8 \quad$ Considerou-se como resultados alcançados pelo INCRA aqueles em que a autarquia federal foi diretamente responsável pela emissão dos títulos às comunidades, inclusive nas situações em que recebeu o apoio dos órgãos estaduais. Os casos em que o INCRA auxiliou com apoio técnico e financeiro mas que não foi
} 


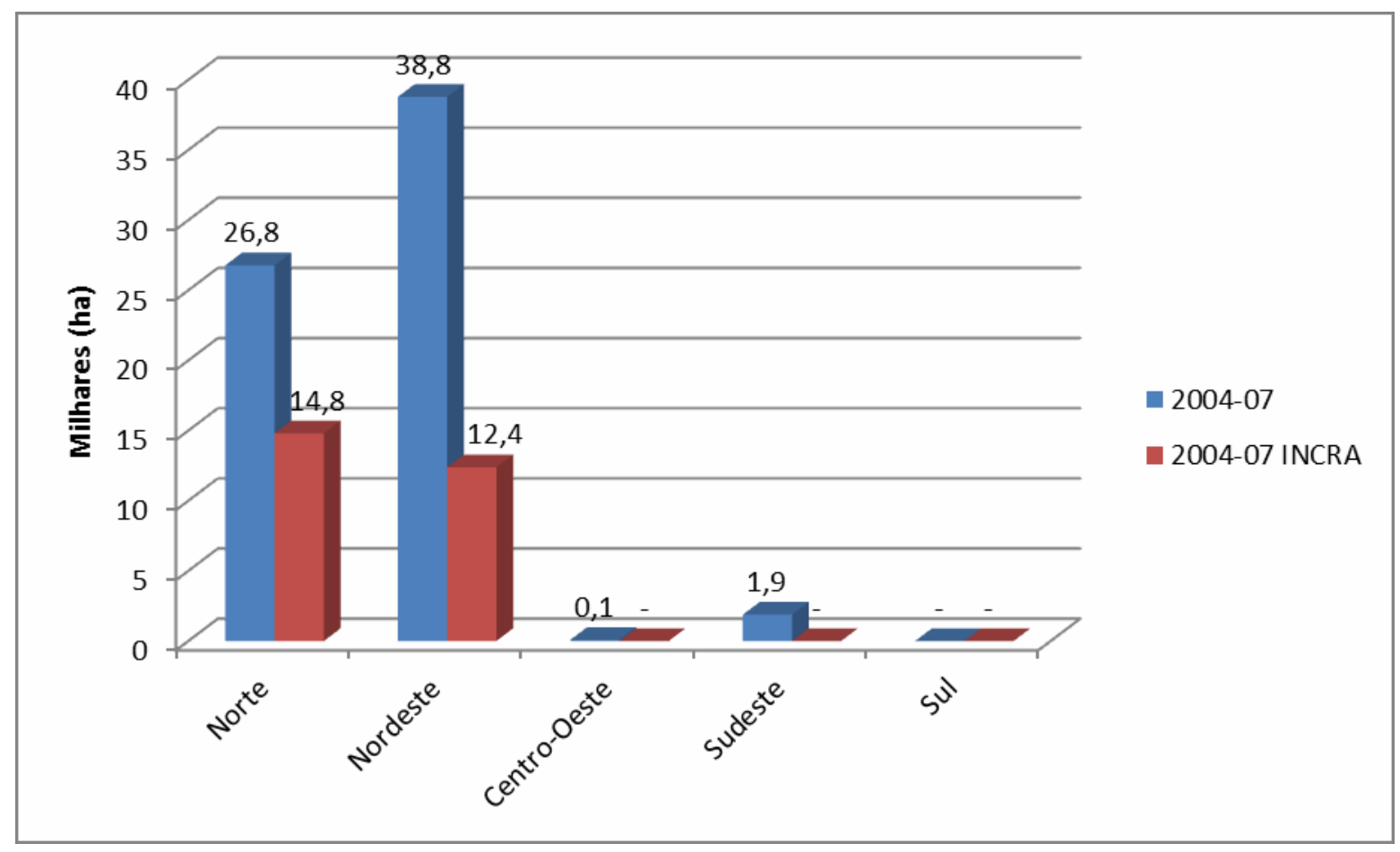

Gráfico 08: Distribuição Regional das Terras Quilombolas Tituladas: PPA 2004-07. Fonte: INCRA/DFQ. Organizado pelo autor.

Entre 2004 e 2007, que correspondem ao primeiro PPA após a publicação do Decreto 4.887 de novembro de 2003, o INCRA fez-se responsável direto ou indireto pela titulação de $40,3 \%$ das terras quilombolas regularizadas. Foi responsável por $55,3 \%$ das terras tituladas na região Norte (14.799 dos 26.778,4 ha) e 31,9\% na região Nordeste (12.372,3 dos 38.776,8 ha). Apesar de esses dados revelarem uma grande participação do INCRA, na proporção dos resultados gerais obtidos em todo o Brasil, nota-se que nenhum hectare de terra quilombola foi titulado, nesse período, pela autarquia federal nas outras regiões brasileiras.

No que se refere ao número de famílias beneficiadas, ocorre uma inversão entre as regiões Norte e Nordeste, haja vista que as ações de titulação de terras quilombolas passaram a atender um maior número de famílias, localizadas na região Nordeste. Percebe-se uma queda expressiva de famílias beneficiadas na região Centro-Oeste, onde não houve nenhuma família beneficiada nesse período, tal qual a região Sul. A Região Sudeste segue com números ínfimos (porém simbolicamente 
importantes) em relação aos observados nas regiões Nordeste e Norte, mas não foram ações desempenhadas pelo INCRA. Nesse período, as famílias beneficiadas por ações do INCRA representaram apenas $16,4 \%$ do total, sendo $19,1 \%$ do verificado na região Norte e $15,9 \%$ das famílias que foram beneficiadas no Nordeste.

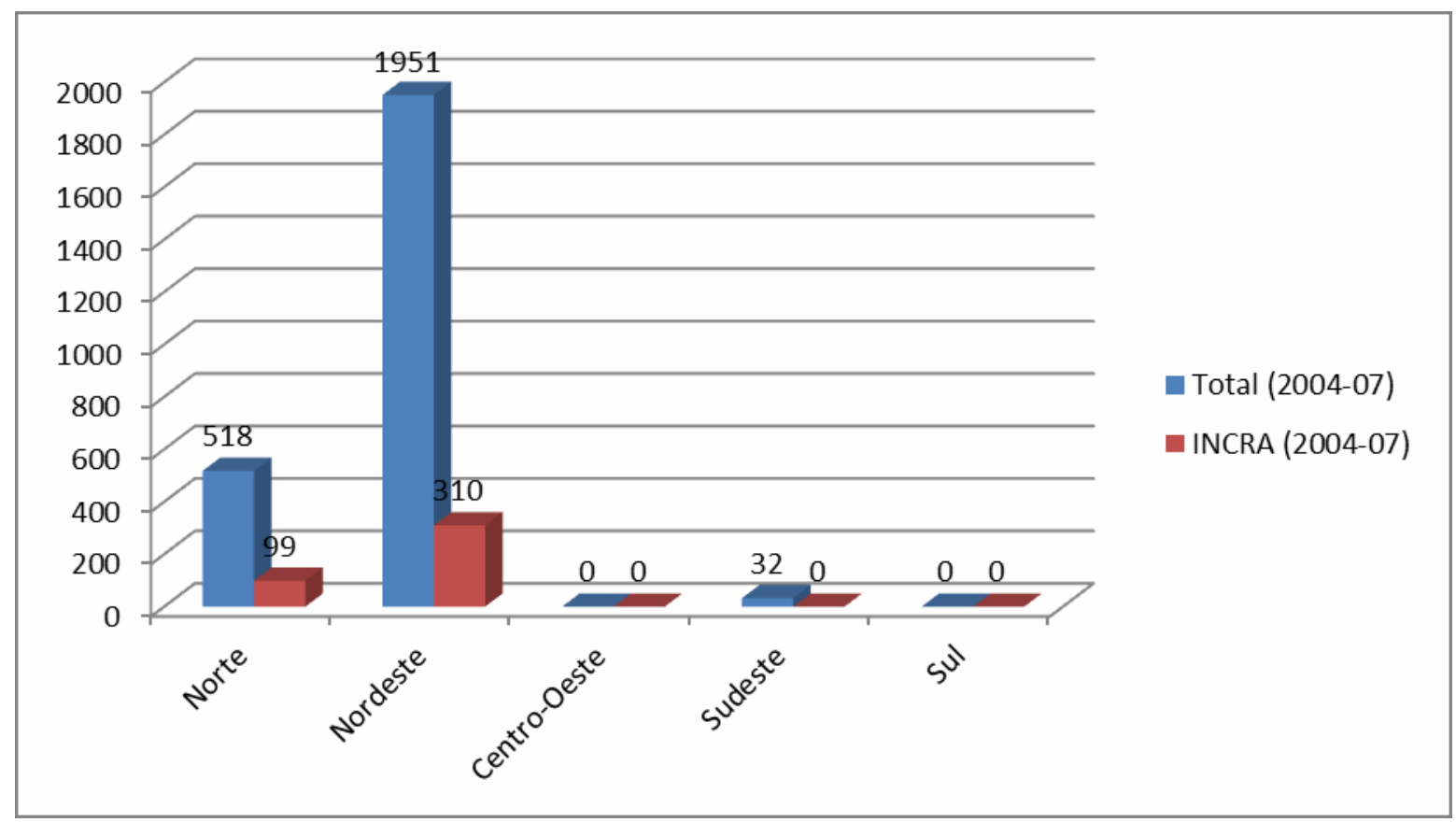

Gráfico 09: Titulação de terras quilombolas: Famílias Beneficiadas. PPA 2004-07. Fonte: DFQ/INCRA. Adaptado pelo Autor.

No PPA 2008-11, nota-se os primeiros resultados alcançados pelo INCRA fora das regiões Norte e Nordeste, representando assim os primeiros títulos quilombolas emitidos nas regiões Centro-Oeste, Sudeste e Sul. 


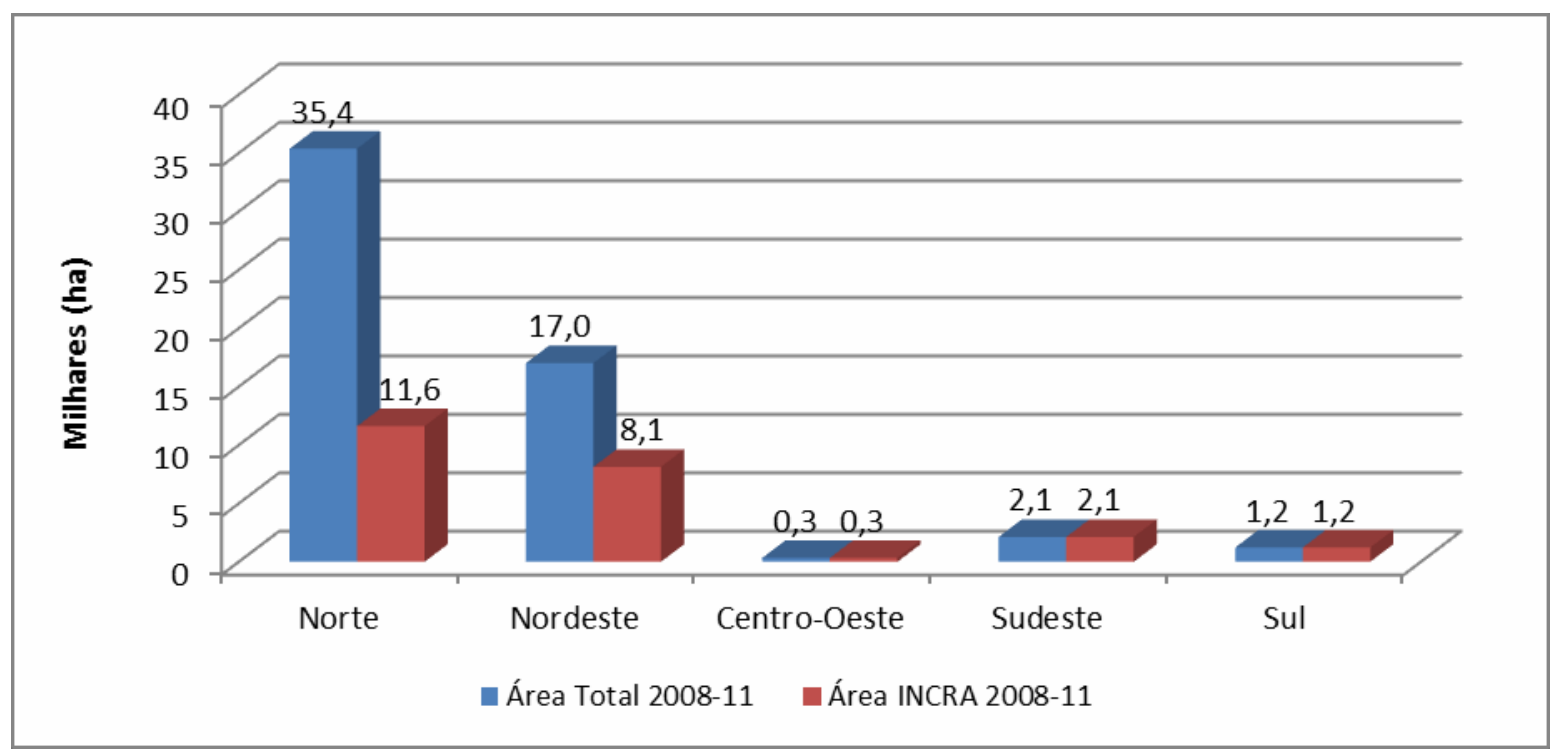

Gráfico 10: Distribuição Regional das Terras Quilombolas Tituladas: PPA 2008 a 2011. Fonte: INCRA/DFQ Organizado pelo autor.

Contudo, a participação do INCRA na proporção de terras quilombolas tituladas no Brasil aumentou para $41,8 \%$, proporção maior do que os $38,6 \%$ alcançados entre 2004 e 2007. No quesito famílias quilombolas beneficiadas no PPA 2008-11, percebe-se que a maior parcela concentra-se na região Nordeste $(52,5 \%)$ e Norte (40,5\%). Contudo, nota-se os primeiros números referentes a famílias da Região Sul: foram 117 famílias beneficiadas no período, representando 5,2\% do total, em ação 100\% executada pelo INCRA, assim como as 28 famílias (1,2\%) beneficiadas na região Centro-Oeste.

Outro ponto que deve ser ressaltado é que, entre 2004 a 2011, período que corresponde aos dois primeiros mandatos presidenciais pós-Decreto 4887 de 2003, o INCRA e órgãos estaduais, em conjunto, titularam um total de 126.393 ha, resultado muito inferior àquele obtido entre os exercícios de 1995 a 2003, que foi de $859.083,3$ ha, ou seja, uma redução de mais de $85 \%$.

Entre 2012 a 2015 os resultados alcançados pelo INCRA alcançaram apenas $24,5 \%$ do total de terras quilombolas tituladas no país (11.805,2 dos 48.230,3 ha tituladas no geral). No Nordeste o INCRA titulou apenas 5.419,2 ha, ou seja, 19,7\% dos 27.483,3 ha titulados na região (INCRA + órgãos estaduais). 


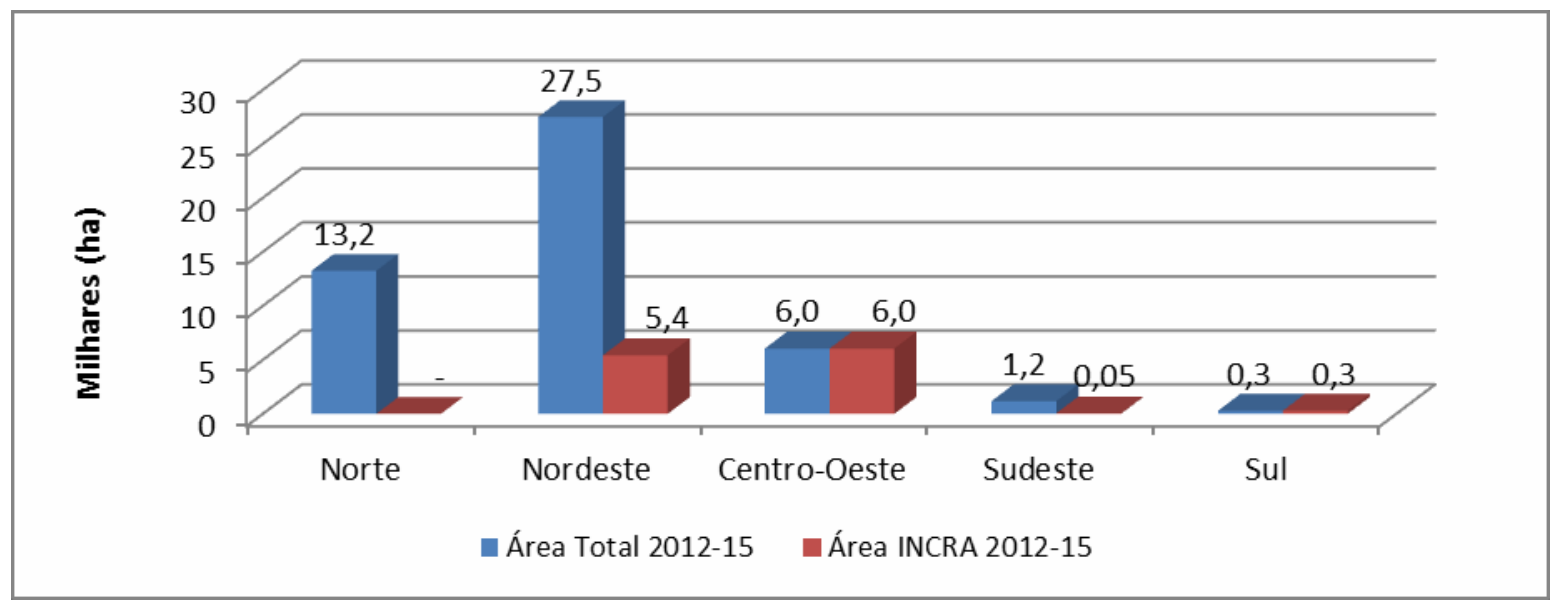

Gráfico 11: Distribuição Regional das Terras Quilombolas Tituladas: PPA 2012 a 2015. Fonte: INCRA/DFQ. Organizado pelo autor.

Na região Sudeste, o INCRA foi responsável por apenas 4,5\% das áreas quilombolas tituladas no período, ou seja, 53 dos 1.174,4 ha. Os 291,5 ha titulados pelo órgão do Governo Federal na Região Sul e os 6.041,5 ha titulados na região Centro-Oeste corresponderam a $100 \%$ dos resultados alcançados nessas regiões, o que representa muito pouco perante a demanda total aí registrada. Este fato demonstra a ineficiência dos órgãos fundiários dessas regiões, em trabalhar políticas públicas fundiárias para as populações quilombolas, diferentemente, do que se observa nas outras regiões.

Contudo, nota-se que não houveram titulações realizadas pelo INCRA na Região Norte nesse período, o que pode significar uma mudança de postura da autarquia em relação à importância estratégica da Região Norte para as ações de titulação das terras quilombolas. É necessário destacar, porém, que algumas comunidades quilombolas ribeirinhas localizadas nos chamados terrenos marginais (margens de rios federais até o limite da linha das enchentes médias ordinárias (LMEO) e nos terrenos de marinha (margens de rios sob influência das marés) foram objeto de regularização de seus territórios (ou parte deles) por ações desenvolvidas pela SPU. Em resposta à consulta realizada àquela Superintendência, foi nos fornecida uma relação de 24 comunidades quilombolas beneficiadas por trabalhos executados pela SPU nesse período: 14 Portarias de Declaração de Interesse do Serviço Público (PDISP); 05 Termos de Autorização de Uso (TAUS); 05 Títulos emitidos via Portaria Interministerial no 210 de Junho de 2014, conforme detalhado 
na Figura 05:

\begin{tabular}{|c|c|c|c|c|c|c|c|}
\hline UF & MUNICIPIO & QUILOMBO & $N^{*}$ PROCESSO & AREA $M^{=}$ & $\begin{array}{c}\mathrm{N}^{\circ} \\
\text { FAMILIAS }\end{array}$ & ATO & ANO \\
\hline AP & Santana & $\begin{array}{l}\text { Săo Raimundo do } \\
\text { Pirativa }\end{array}$ & $\begin{array}{c}05315.001138 / 2011- \\
67\end{array}$ & 234.184 & 17 & PDISP & 2013 \\
\hline BA & Carinhanha & Barra do Parateca & $\begin{array}{c}04941.001185 / 2010- \\
81\end{array}$ & $6.718 .056,24$ & 280 & PDISP & 2013 \\
\hline$B A$ & $\begin{array}{c}\text { Bom Jesus da } \\
\text { Lapa }\end{array}$ & Lagoa das Piranhas & $\begin{array}{c}04941.000354 / 2013- \\
16\end{array}$ & $52.439 .462,88$ & 109 & PDISP & 2013 \\
\hline BA & $\begin{array}{c}\text { Bom Jesus da } \\
\text { Lapa }\end{array}$ & $\begin{array}{c}\text { Nova Batalhinha / } \\
\text { Pitombeira }\end{array}$ & $\begin{array}{c}04941.006073 / 2013- \\
68\end{array}$ & 74.730 .000 & 74 & PDISP & 2013 \\
\hline BA & $\begin{array}{c}\text { Bom Jesus da } \\
\text { Lapa }\end{array}$ & Lagoa do Peixe & \begin{tabular}{|c|}
$04941.005853 / 2014-$ \\
72
\end{tabular} & $30.439 .880,44$ & 150 & PDISP & 2014 \\
\hline BA & Cachoeira & $\begin{array}{l}\text { Caonge, Dende e } \\
\text { outros }\end{array}$ & $\begin{array}{c}04941.006074 / 2013- \\
11\end{array}$ & 469.012 & 70 & PDISP & 2014 \\
\hline BA & Maragogipe & Guerém/Guaraçu & \begin{tabular}{|c|}
$04941.006071 / 2013-$ \\
70
\end{tabular} & $2.818 .307,24$ & 350 & PDISP & 2014 \\
\hline BA & $\begin{array}{l}\text { São Francisco } \\
\text { do Conde }\end{array}$ & Porto Dom João & $\begin{array}{c}04941.013623 / 2011- \\
34\end{array}$ & 1.790 .744 & 90 & PDISP & 2015 \\
\hline$B A$ & Maragogipe & Salamina Putumuju & $\begin{array}{c}04941.008088 / 2013- \\
56\end{array}$ & 647.116 & 40 & PDISP & 2014 \\
\hline BA & $\begin{array}{l}\text { Salinas das } \\
\text { Margaridas }\end{array}$ & Conceiçăo de Salinas & \begin{tabular}{|c|}
$04987.010324 / 2008-$ \\
82 \\
$04967.003875 / 2010-$ \\
86 \\
\end{tabular} & 145.886 .68 & 30 & PDISP & 2015 \\
\hline SE & $\begin{array}{l}\text { Barra dos } \\
\text { Coqueiros }\end{array}$ & Pontal da Barra & $\begin{array}{c}04906.002774 / 2012- \\
74 \\
\end{array}$ & $1.176 .159,87$ & 135 & PDISP & 2013 \\
\hline SE & \begin{tabular}{|c|} 
Amparo do Săo \\
Francisco
\end{tabular} & Lagoa de Campinhos & $\begin{array}{c}04906.001392 / 2013- \\
12\end{array}$ & $11.820 .400,39$ & 103 & PDISP & 2013 \\
\hline $\mathrm{BA}$ & Salvador & Tha da Maré & $\begin{array}{c}04941.006072 / 2013- \\
14\end{array}$ & $64.473,56$ & 628 & PDISP & 2013 \\
\hline MA & Alcântara & Illha do Cajual & $\begin{array}{c}04952.002920 / 2013- \\
97\end{array}$ & $53.335,38$ & & PDISP & 2013 \\
\hline OTAL & \multicolumn{2}{|c|}{14 COMUNIDADES } & \multicolumn{3}{|c|}{$183.647 .120,20 \mathrm{~m}^{2}$, aproximadamente } & \multicolumn{2}{|c|}{2076 familias. } \\
\hline UF & MUNICIPIO & QUILOMBO & $\mathrm{N}^{\circ}$ PROCESSO & AREA $M^{2}$ & \begin{tabular}{c|}
$\mathrm{N}^{\circ}$ \\
FAMILIAS \\
\end{tabular} & ATO & ANO \\
\hline MA & Alcântara & Ilha do Cajual & $\begin{array}{l}\begin{array}{c}04952.002920 / 2013- \\
97\end{array} \\
\end{array}$ & $53.335,38$ & & TAUS & 2013 \\
\hline MS & Corumbá & Familia Ozório & $\begin{array}{c}54290.001605 / 2010- \\
17\end{array}$ & $6.734,75$ & 14 & TAUS & 2012 \\
\hline $\mathrm{PA}$ & Colares & Cacau e Ovos & $\begin{array}{l}04957.013798 / 2013- \\
88\end{array}$ & 35.137 .660 & 28 & TAUS & 2013 \\
\hline PA & Santarém & Arapema & $\begin{array}{c}04957.013798 / 2013- \\
88\end{array}$ & 38.289 .788 & 76 & TAUS & 2013 \\
\hline 5 PA & Santarém & tha Saracura & \begin{tabular}{|c}
$04957.013798 / 2013-$ \\
88
\end{tabular} & 28.898 .571 & 135 & TAUS & 2013 \\
\hline OTAL & \multicolumn{2}{|r|}{5 COMUNIDADES } & \multicolumn{3}{|c|}{$102.387 .090,13 \mathrm{~m}^{2}$, aproximadamente } & \multicolumn{2}{|c|}{253 familias. } \\
\hline UF & MUNICIPIO & QUILOMBO & $\mathrm{N}^{*}$ PROCESSO & AREA $M^{2}$ & \begin{tabular}{|c|}
$N^{\circ}$ \\
FAMILIAS
\end{tabular} & ATO & ANO \\
\hline BA & $\begin{array}{c}\begin{array}{c}\text { Bom Jesus da } \\
\text { Lapa }\end{array} \\
\end{array}$ & Lagoa das Piranhas & $\begin{array}{c}04941.000354 / 2013- \\
16 \\
\end{array}$ & $52.439 .462,38$ & 109 & INCRA & 2013 \\
\hline SE & \begin{tabular}{|c|}
$\begin{array}{c}\text { Amparo de Săo } \\
\text { Francisco }\end{array}$ \\
\end{tabular} & Lagoa de Campinhos & $\begin{array}{c}04908.001392 / 2013- \\
12\end{array}$ & 1.192 .040 & 103 & INCRA & 2013 \\
\hline SE & $\begin{array}{l}\text { Barra dos } \\
\text { Coqueiros }\end{array}$ & Pontal da Barra & \begin{tabular}{|c|}
$04906.002774 / 2012-$ \\
74
\end{tabular} & 1.176 .160 & 135 & INCRA & 2013 \\
\hline RJ & Magaratiba & Marambaia (seis áreas) & 04967.005809/2008-10 & 547.900 & 24 & INCRA & 2015 \\
\hline 5 SP & Ubatuba & Caçandoca & $\begin{array}{c}04977.005333 / 2006- \\
42\end{array}$ & $336.740,85$ & 80 & INCRA & 2015 \\
\hline OTAL & \multicolumn{2}{|r|}{5 COMUNIDADES } & \multicolumn{3}{|c|}{$55.692 .303,24 \mathrm{~m}^{2}$, aproximadamente } & \multicolumn{2}{|c|}{521 familias } \\
\hline
\end{tabular}

Figura 05: Comunidades Quilombolas beneficiadas por Ações da SPU: PPA 2012 a 2015. Fonte: SPU.

No que se refere ao número de famílias beneficiadas, observa-se que no PPA 2012-15 nenhuma família quilombola foi titulada diretamente pelo INCRA na região Norte. Por outro lado, os resultados da autarquia se concentraram, basicamente, na Região Nordeste, onde beneficiou 2.027 famílias (55,4\% do total). Porém, são 
relativamente expressivas as ações executadas nas regiões Centro-Oeste, Sudeste e Sul, onde o INCRA foi responsável por $100 \%$ das ações que beneficiaram as famílias dessas regiões: 619 famílias no Centro-Oeste, 139 na região Sul e 124 famílias na região Sudeste. Cabe destacar ainda que, no PPA 2012-15, a Autarquia Federal foi responsável por 59,7\% das famílias atendidas, o que representa sua maior participação em todo o período analisado nessa pesquisa (1995 a 2015).

Tomando como referência o período compreendido entre os exercícios de 2004 a 2015, ou seja, nos 03 PPA's completos subsequentes ao Decreto 4.887 de 2003, os resultados alcançados pelo INCRA representaram apenas 35,72\% do total de terras quilombolas tituladas no país (62.378,5 dos $174.623,5$ ha regularizados). Nesse período, as ações de regularização de terras quilombolas, seja no âmbito federal ou nos órgãos fundiários estaduais, titularam a maior parte das terras nos estados da região Nordeste: $83.267,75$ ha $(47,68 \%)$, seguido pela região Norte, onde foram titulados $78.237,4$ ha $(44,8 \%)$. As regiões Centro-Oeste, Sudeste e Sul apresentaram $6.447,9$ ha $(3,7 \%), 5.169,6$ ha $(3,0 \%)$ e $1.500,8$ ha $(0,86 \%)$, respectivamente.

Considerando apenas as titulações realizadas pelo INCRA (Figura 06), a maior concentração de terras tituladas também foi na região Nordeste, com 25.916,8 ha $(47,68 \%)$, seguida pela região Norte, com $26.407,7$ ha $(33,75 \%)$; Centro-Oeste, com $6.374,6$ ha $(98,9 \%)$; Sudeste, com $2.178,7$ ha $(42,1 \%)$; Sul, com $1.500,8$ ha $(100 \%)$. 


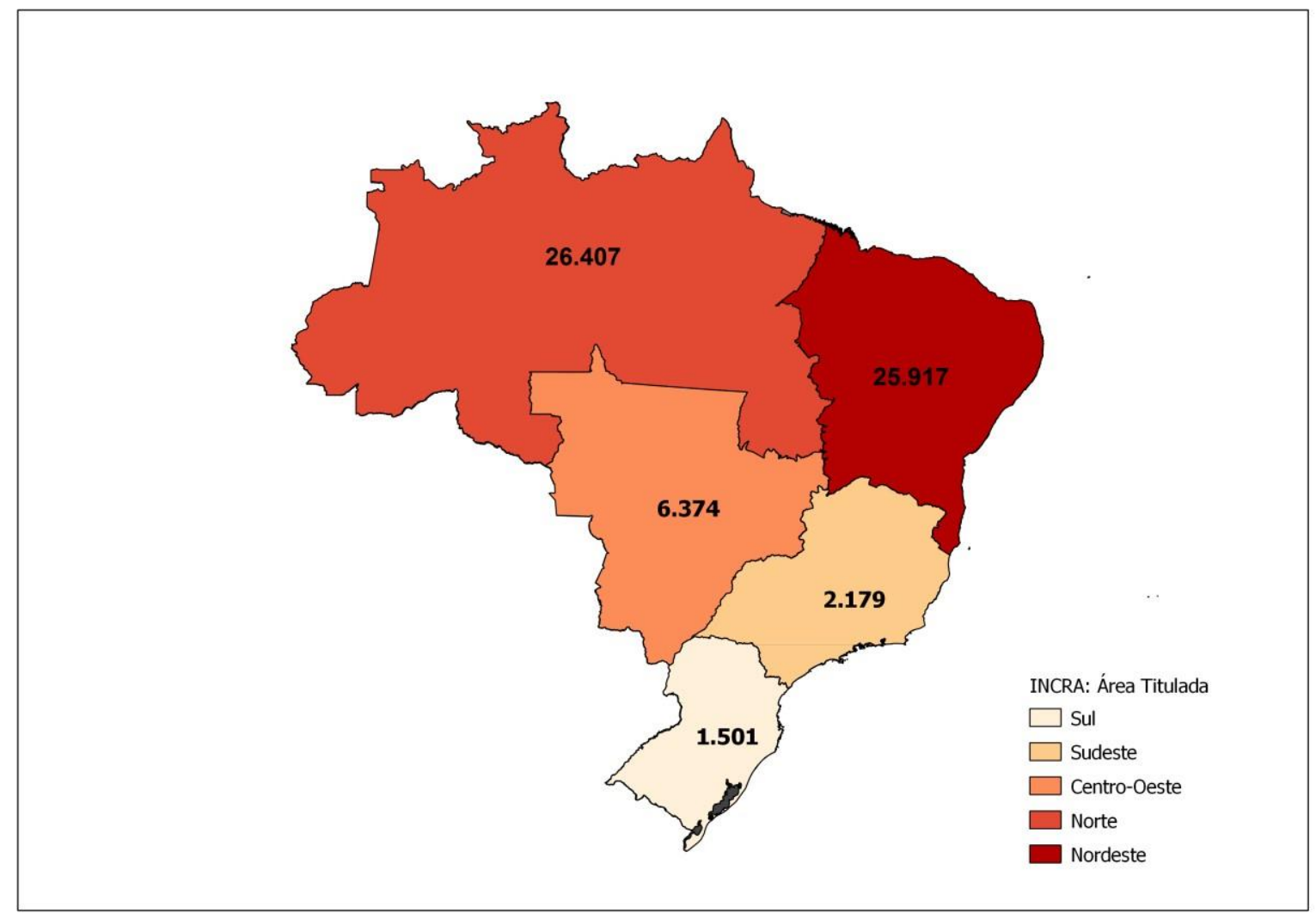

Figura 06: INCRA: Área Titulada por Região Administrativa: 2004 a 2015, em hectares. Fonte: INCRA/DFQ. Organizado pelo Autor.

Além de a região Norte não ter apresentado nenhum título emitido pelo INCRA no PPA 2012-15, nota-se também que os resultados obtidos na região Nordeste, que é aquela que apresenta a maior demanda por titulação de terras quilombolas, vem apresentando uma clara tendência de redução. A única região, a apresentar um incremento na titulação das terras foi a Centro-Oeste que, inclusive, é a região que apresentou o maior número de hectares titulados no período, conforme constatado no Gráfico 12: 


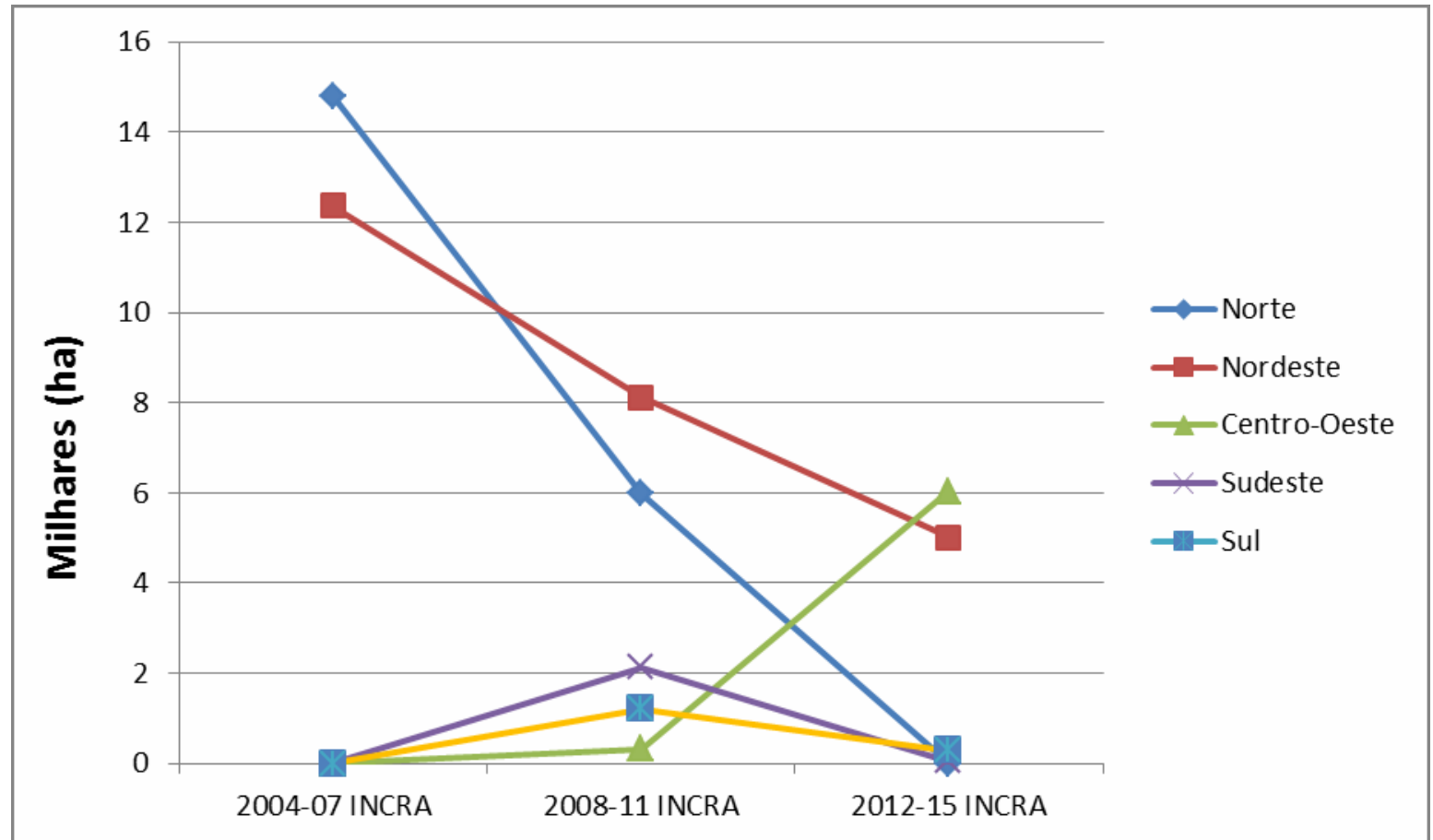

Gráfico 12: INCRA: Evolução da distribuição espacial das terras quilombolas tituladas, por Região e PPA - 2004 a 2015. Fonte: INCRA/DFQ. Organizado pelo Autor.

No que se refere às famílias quilombolas beneficiadas, nota-se a partir dos dados dispostos no Gráfico 12 que há uma forte tendência de concentração de resultados na região Nordeste e Centro-Oeste, enquanto que as dificuldades históricas de se alavancar os resultados na região Sudeste e Sul persistiram em todos os períodos avaliados. 


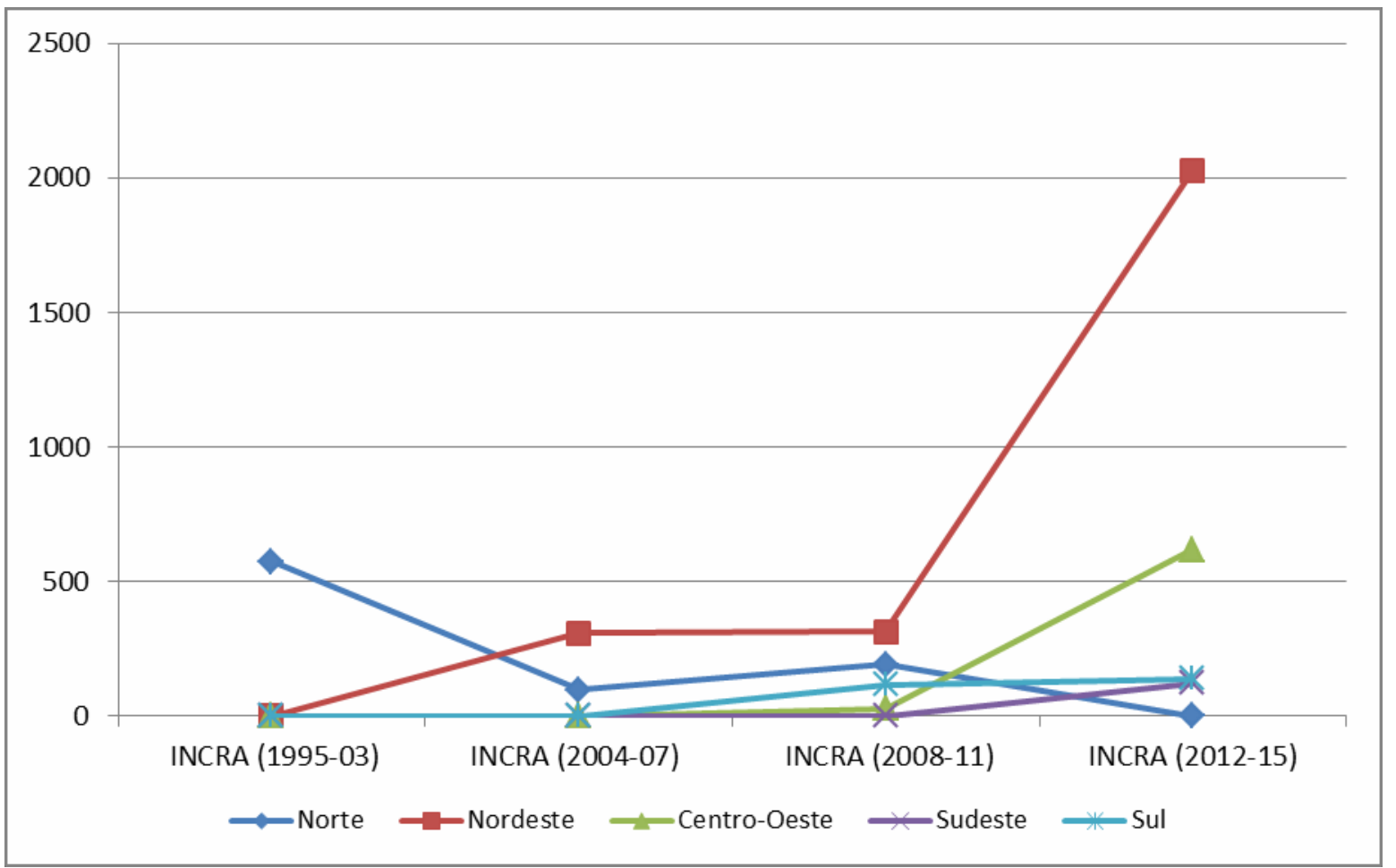

Gráfico 13: INCRA - Titulação de Terras Quilombolas: Famílias Beneficiadas, 1995 a 2015. Fonte: DFQ/INCRA. Adaptado pelo autor.

Analisando-se as famílias beneficiadas pelo INCRA, em cada uma das, regiões apenas no período pós-Decreto 4.887, os dados apontam que $66,8 \%$ localizam-se na região Nordeste, $16,3 \%$ na região Centro-Oeste, $7,3 \%$ na região Norte, $6,4 \%$ na região Sul e apenas 3,1\% na região Sudeste.

Além da curva descendente das terras tituladas pelo INCRA nas regiões Norte e Nordeste, também chama a atenção a baixíssima efetividade das ações de titulação das terras quilombolas nas regiões Sudeste e Sul. Esse fenômeno pode estar relacionado a vários fatores, que vão desde a extrema burocratização a que está vinculada a normatização dos trabalhos relativos ao processo de regularização dos territórios quilombolas, materializada na Instrução Normativa INCRA n 57 de 2009, que regulamenta o Decreto 4.887 de 2003 até à dificuldade de se transpor as barreiras impostas pelos processos de desintrusão dos proprietários e ocupantes não-quilombolas do perímetro do território reconhecido. Mas existem outras questões que são tão importantes quanto estas para a constituição desse cenário. Rodrigues (2010, p.272) conclui que 
As maiores cobranças em termos de gestão eficiente dos recursos orçamentários, representação pública dos interesses das comunidades e consolidação da política fundiária concentram-se no Instituto de Colonização e Reforma Agrária (Incra, responsável pelo processo de titulação), na FCP (órgão emissor da certidão de autorreconhecimento quilombola) e na Seppir (órgão de coordenação da política). (...) O número maior de certificações que titulações evidencia as fases do intrincado processo fundiário. Na fase inicial, junto à FCP, prevalece a articulação política das comunidades e movimentos negros para dar os primeiros passos rumo ao reconhecimento. Porém, a chegada ao ponto final dessa caminhada significa cruzar a zona burocrática, técnica e política que se impõe à titulação. Até agora, poucas comunidades têm cruzado essa zona. (RODRIGUES, 2010, p.272-273)

Nesse contexto, Rodrigues (2010, p.273) ressalta ainda que a problemática não envolve, apenas, atestar ineficiência deste ou daquele órgão governamental, mas demonstrar onde está o gargalo da questão. Explora questionamentos que provocam a reflexão a respeito das causas das discrepâncias entre o número de certificações (FCP) e titulações (INCRA), assim como 0 fato de que, coincidentemente, no ano eleitoral de 2006, certificações e titulações atingem os números mais elevados do período avaliado por sua pesquisa.

Para responder à primeira questão é preciso refletir sobre os significados de "certificar" uma comunidade quilombola e "titular" o território dessa comunidade. $\mathrm{Na}$ certificação, dá-se apenas o reconhecimento oficial de uma situação preexistente, de um território formalmente ocupado, ou seja, altera-se o status social do grupo, sem promover a sustentabilidade desse status. (...) entre a certificação e a titulação há uma correlação de forças que se sobrepõe aos interesses quilombolas. Nesse sentido, talvez só a crescente e articulada mobilização política, como a ocorrida em 2006 nas "brechas" de uma pressão/negociação em contexto favorável, possa alterar ou equilibrar essa balança. (RODRIGUES, 2010, p.273)

Um dos pontos que contribuem para a compreensão dessas questões é a análise da gestão dos recursos orçamentário-financeiros destinados às ações de titulação das terras quilombolas. Uma das importantes contribuições nesse tipo de análise vem de Arruti (2009, p.80), que destaca

(...) a execução orçamentária do PBQ ficou muito aquém do previsto e prometido. Entre 2004 e 2007, por exemplo, o programa gastou apenas $32,8 \%$ do seu orçamento. Em 2008, o Programa chegou a ter 
uma perda no volume de recursos orçados de $\mathrm{R} \$ 15,3$ milhões. Neste contexto, a situação da principal ação reivindicada pelo movimento quilombola, relativa à regularização dos territórios de uso comum, foi ainda pior: o MDA só aplicou $21,75 \%$ do orçamento destinado. Como descreve um relatório do Inesc (2008), deste montante, cerca de $\mathrm{R} \$ 6$ milhões deixaram de ser aplicados na elaboração de Relatórios Técnicos de Identificação e Delimitação (RTID).

Nesse contexto, também é de grande destaque o trabalho desenvolvido pelo Instituto de Estudos Sócio Econômicos (INESC), que divulgou uma série de Notas Técnicas que oferece uma perspectiva crítica dos resultados das políticas quilombolas. Na Nota Técnica 126, de junho de 2007, intitulada Orçamento Quilombola: Governo Federal orça, mas não gasta -, declara que

Se considerarmos que o desempenho orçamentário-financeiro é um indicador válido para avaliar políticas públicas, os números referentes ao Orçamento Quilombola no período 2004-2006 mostram que, não obstante o aumento progressivo ano a ano dos valores orçados, há problemas a serem resolvidos em diferentes frentes (ou setores) de trabalho e esses problemas têm se refletido num desempenho financeiro aquém do almejado. (INESC, 2007, p.02)

Não obstante, provoca uma reflexão para o apontamento das razões da baixa execução orçamentária para o período, especialmente nas ações de Regularização de Territórios Quilombolas, onde aponta que

O Ministério do Desenvolvimento Agrário (MDA), responsável pela regularização fundiária das Terras Quilombolas, só conseguiu gastar $\mathrm{R} \$ 20,93 \%$ do orçamento autorizado ao órgão pelo Congresso Nacional no período, que foi de $\mathrm{R} \$ 70,70$ milhões (INESC, 2007, p.02).

Identificou, nesse contexto, duas ações que pesaram negativamente para a constituição desse quadro

(1) a ação Reconhecimento, demarcação e titulação de áreas remanescentes de quilombos, para a qual foi autorizado montante total de $R \$ 11,01$ milhões e gastos $R \$ 5,94$ milhões (53,97\%); e (2) a ação Pagamento de indenizações aos ocupantes das terras demarcadas e tituladas aos remanescentes de quilombos, que teve autorização de $R \$ 56,53$ milhões e gastou $R \$ 6,58$ milhões $(11,65 \%)$ 
ao longo dos três anos. (INESC, 2007, p.03)

Ademais, o relatório é taxativo ao concluir que

A questão é objetiva: ou o Governo federal enfrenta para valer os desafios operacionais e, principalmente, os interesses políticos que vêm dificultando o reconhecimento dos direitos das populações quilombolas ou continuará reproduzindo nos próximos anos um baixo desempenho financeiro, com reflexos diretos nos resultados e impactos de programas e ações criados. (INESC, 2007, p.04)

A Nota Técnica INESC 139 de 2008, intitulada Orçamento Quilombola: entre o Previsto e o Gasto, traz uma perspectiva para as ações de titulação de terras quilombolas a partir da previsão orçamentária (LOA) para o exercício 2008. No que se refere às ações de titulação de territórios quilombolas, denuncia que

As ações mais afetadas foram aquelas desenvolvidas pelo Incra, órgão responsável pelo "reconhecimento, demarcação e titulação" das terras quilombolas, que perdeu $R \$ 15,48$ milhões, sendo $R \$ 1,78$ milhão para a produção de relatórios técnicos de identificação e delimitação (RTID). (INESC, 2008, p.02)

A Nota 139 de 2008 é bastante representativa por trazer a fala da então ministra de Políticas de Promoção da Igualdade Racial (SEPPIR), Matilda Ribeiro, reconhecendo a baixa execução orçamentária dos recursos para quilombolas e identificando uma combinação de fatores que, na visão da mesma, explicaria esse fenômeno:

Entre eles, a falta de uma visão e de uma atuação histórica dos
ministérios na área de quilombos, o que levaria os Ministérios a
começarem de maneira focada, a partir de diagnósticos da realidade
da comunidade. Por se tratar de uma política nova para a estrutura
de governo, afirmou Matilde, "isso requer ajuste sistemático e
monitoramento bastante diretivo e a decisão dos governos quanto à
continuidade desses programas". (INESC, 2008, p.03)

Ao realizar um balanço do período correspondente ao Plano Plurianual 200407, INESC (2008, p.04) constata que 
(...) cerca de $\mathrm{R} \$ 139$ milhões deixaram de ser aplicados nas ações que compõem os três programas orçamentários estruturantes da política de promoção de direitos das comunidades quilombolas e dos afrodescendentes em geral. O Programa Brasil Quilombola teve no período 2004-07 um orçamento aprovado de $R \$ 150,26$ milhões, aplicando desse montante pouco mais de $\mathrm{R} \$ 48,49$ milhões $(32,27 \%)$. (INESC, 2008, p. 04 -05)

No contexto específico das ações de titulação das terras quilombolas, a Nota 139 de 2008 aponta que o Ministério do Desenvolvimento Agrário (MDA), só conseguiu aplicar $21,75 \%$ do orçamento autorizado para a pasta, que foi de $\mathrm{R} \$ 104,10$ milhões. Destaca ainda que

É certo que boa parte desse recurso se destinava ao pagamento de indenizações aos ocupantes das terras demarcadas e tituladas, mas também é certo que cerca de $R \$ 5,94$ milhões deixaram de ser aplicados, entre outras coisas, na elaboração de Relatórios Técnicos de Identificação e Delimitação (RTID) dos territórios quilombolas. No apoio ao desenvolvimento sustentável das comunidades quilombolas, deixou de ser aplicado R\$1,6 milhão. (INESC, 2008, p.05)

Na Nota Técnica INESC 179 de novembro de 2012, intitulada O Orçamento das Políticas Federais de Promoção da Igualdade Racial e Combate ao Racismo: Baixa Prioridade e Execução, O INESC (2012) é taxativo ao afirmar que

O governo Dilma tem elegido algumas prioridades programáticas como, por exemplo, o Programa de Aceleração do Crescimento (PAC), o programa Brasil sem Miséria e o Programa Minha Casa, Minha Vida. Assim como outras áreas, a promoção da igualdade racial e o combate ao racismo, não está entre as prioridades do governo federal. Além dos poucos recursos alocados, a execução dos mesmos ao longo do ano é muito baixa. (INESC, 2012, p. 07)

A Nota Técnica INESC 179 deve também ser ressaltada pela denúncia que traz, em relação a uma inovação técnica estipulada no Projeto de Lei Orçamentária - PLOA de 2013, em que promoveu a aglutinação de diversas ações orçamentárias em rubricas generalistas: 
ações propostas pelo governo. Essas medidas irão dificultar a continuidade de uma série histórica e a construção de instrumento de acompanhamento dos recursos destinados para políticas de promoção da Igualdade, como o Orçamento da Igualdade Racial, assim como, políticas para mulheres, indígenas etc. (...) as mudanças efetuadas deixaram o orçamento menos transparente, com menor possibilidade de discussão de prioridades por parte do Parlamento e das organizações da sociedade civil e com dificuldades extras para o monitoramento e a participação social. (INESC, 2012, p.15)

No contexto das ações de regularização de territórios quilombolas, afirma que

(...) temos um amplo conjunto de atores institucionais atuando junto a essas comunidades, acrescido de um conjunto mais amplo de organizações sociais, prefeituras etc., que em alguns casos recebem recursos federais mediante o estabelecimento de convênios. O difícil é saber exatamente quem, quanto é investido, onde, como e que resultados foram alcançados; mais difícil ainda é saber os impactos gerados no modo de vida das comunidades e como as pessoas estão percebendo a atuação desses órgãos. Tão difícil quanto acessar esse tipo de informação é ela ser produzida de forma autônoma das concepções e interesses dos gestores. Além da falta de transparência, fruto talvez da inexistência de um sistema de acompanhamento e avaliação eficiente, o acesso está limitado a "dados" administrativos de qualidade duvidosa. (INESC, 2010, p.04)

Nesse sentido, buscando complementar a série de estudos do INESC, realizamos um levantamento dos valores orçamentários e financeiros federais envolvidos nas ações de titulação de terras quilombolas à luz do contexto social e político que influenciaram a tomada de decisões do Governo Federal, no período referente aos anos 2004 a 2015, com base nos dados fornecidos pelo INCRA.

Nesse contexto, uma estratégia relevante é o estudo da variação anual dos recursos previstos na Lei Orçamentária (LOA), ou seja, qual o valor planejado pelo Governo Federal para as ações de titulação das terras quilombolas, confrontando-os com os valores que foram autorizados para execução e, sem seguida, com aqueles valores efetivamente pagos ou executados. Esses dados são relevantes à medida que nos revelam a capacidade de execução do orçamento previsto na Lei Orçamentária Anual (LOA) e nos Planos Pluri-Anuais (PPA's), dentre outros fatores relativos à gestão dessas ações. 


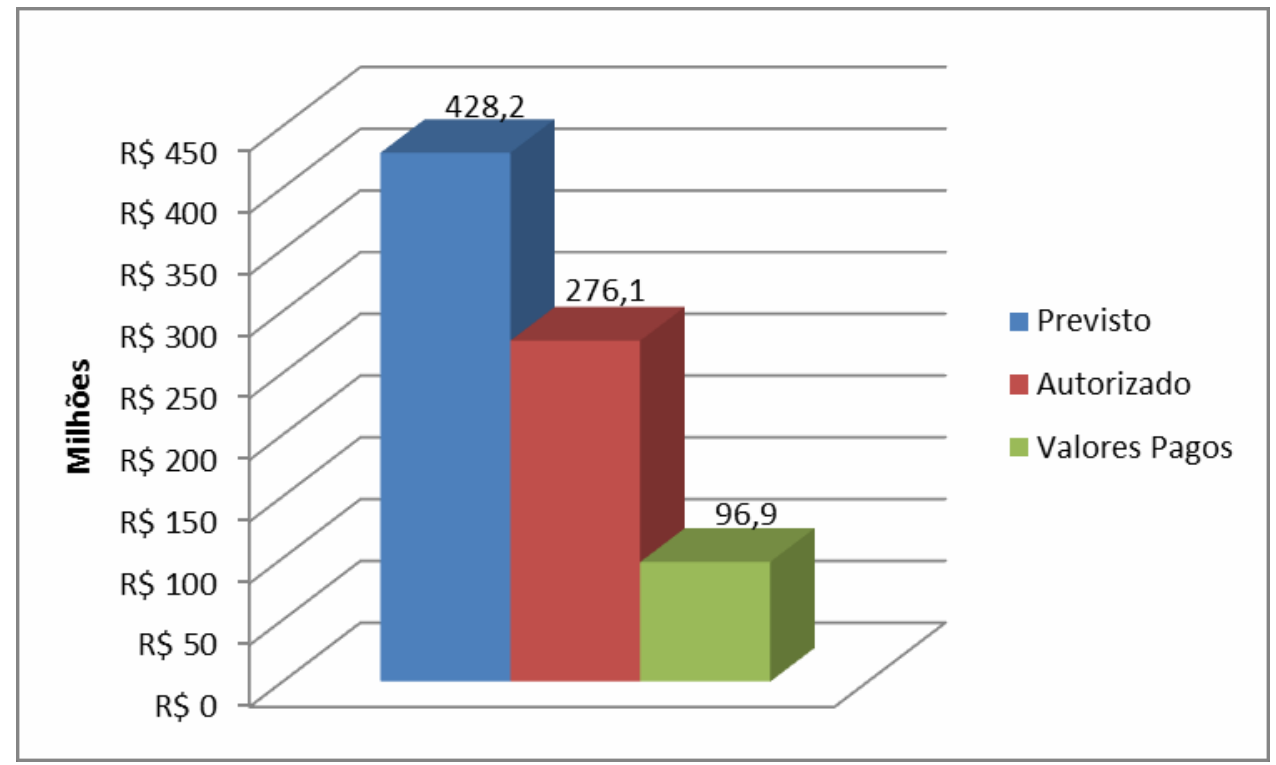

Gráfico 14: INCRA: Recursos Previstos, Autorizados e Pagos nas ações de titulação de terras quilombolas: 2004 a 2015. Fonte: INCRA/DFQ. Organizado pelo autor.

Conforme pode ser observado no Gráfico 14, há uma enorme discrepância entre:

- O montante de recursos que o Governo Federal planejou para as ações de titulação das terras quilombolas e o que de fato autorizou, para que o INCRA executasse no decorrer dos respectivos exercícios: Governo Federal autorizou apenas $64,5 \%$ do que foi planejado;

- O montante que o INCRA efetivamente conseguiu executar, seja produzindo RTID's ou indenizando os proprietários não-quilombolas, que sofreram o processo de desintrusão: o INCRA conseguiu executar apenas 35,1\% do que foi autorizado.

Convém ressaltar que, em termos das ações de regularização de territórios quilombolas do Governo Federal, os recursos orçamentários e financeiros são agrupados em dois grupos:

- Das despesas correntes, que são aquelas voltadas ao custeio dos estudos técnicos que visam à elaboração de Relatórios Técnicos de Identificação e Delimitação (RTID’s) dos territórios quilombolas (diárias de servidores, passagens, combustível, pagamento de pessoas jurídicas etc); 
- Das despesas de capital, que visam a indenização das terras reconhecidas pelo Estado como tradicionalmente pertencentes às comunidades quilombolas sendo, portanto, necessária a indenização aos proprietários após a decretação como áreas de interesse social, para que se possam ser emitidos os títulos em favor da comunidade quilombola, num processo conhecido no INCRA como obtenção de imóveis.

O Gráfico 15 demonstra o montante de recursos organizados por natureza da despesa e confirma o que foi previsto, autorizado e efetivamente pago, no período compreendido entre os exercícios de 2004 a 2015:

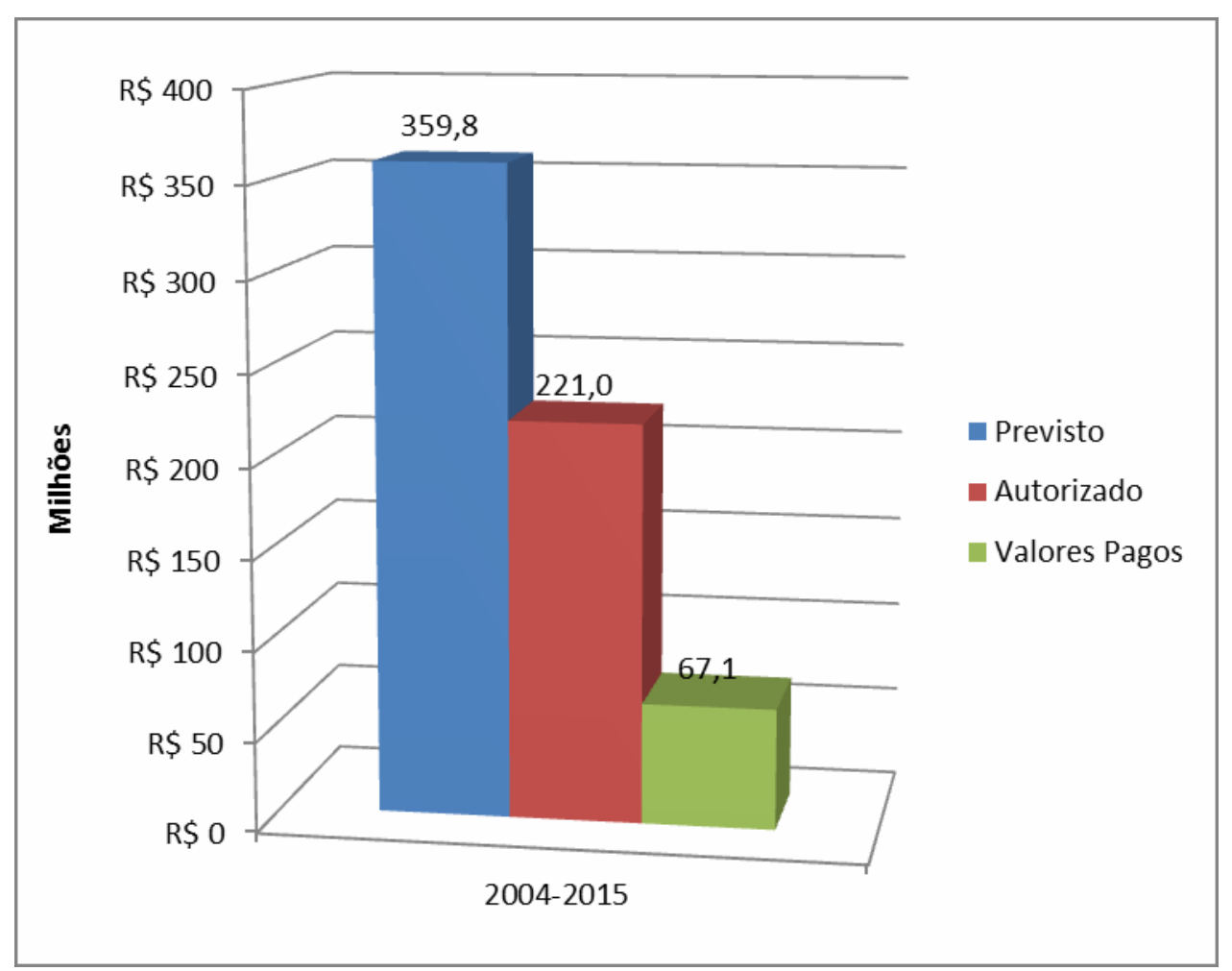

Gráfico 15: DESPESAS DE CAPITAL: Recursos Previstos, Autorizados e Pagos pelo INCRA nas ações de titulação de terras quilombolas, 2004 a 2015. Fonte: INCRA/DFQ. Organizado pelo autor. 


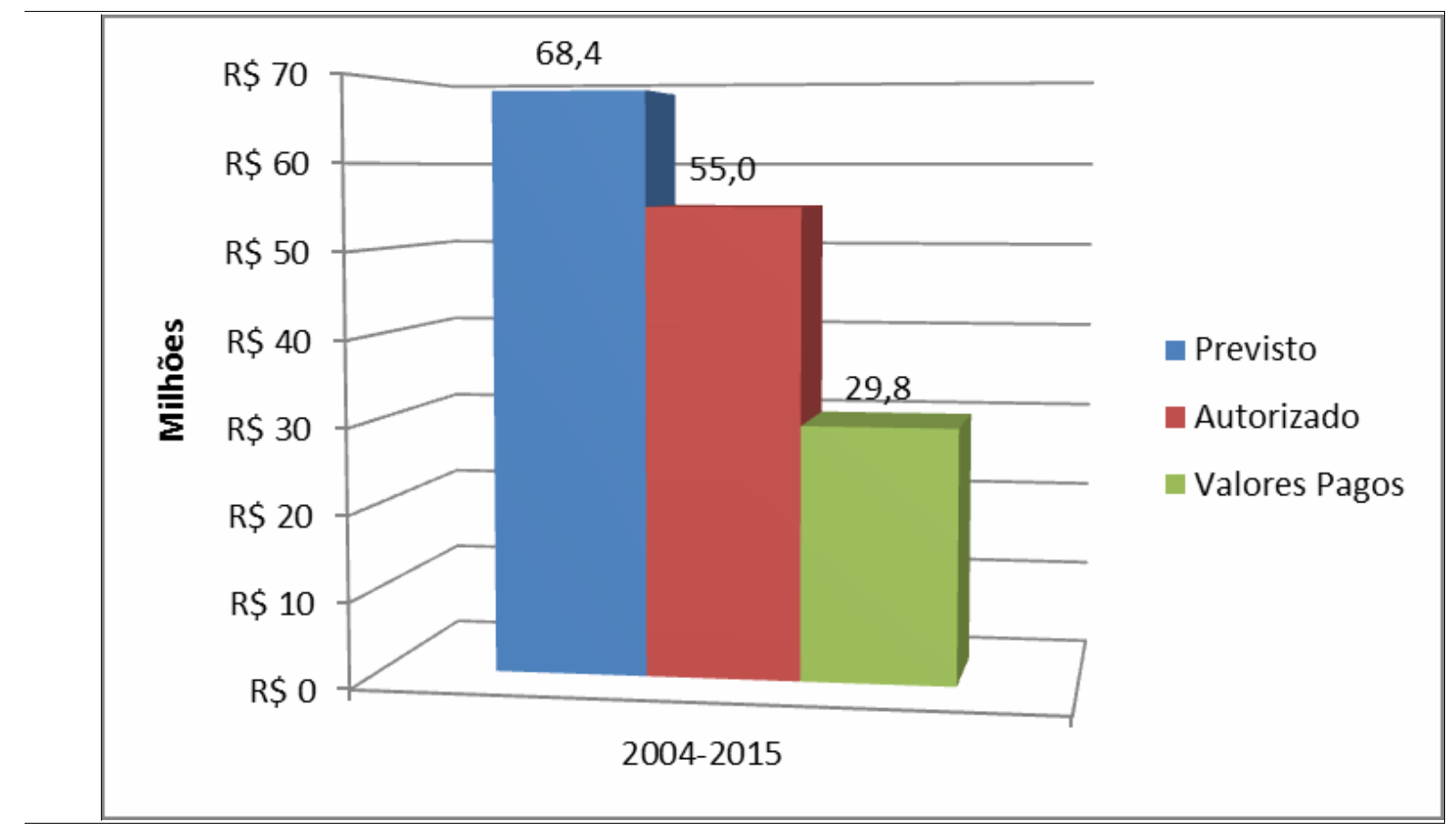

Gráfico 16: DESPESAS CORRENTES: Recursos Previstos, Autorizados e Pagos pelo INCRA nas ações de titulação de terras quilombolas, 2004 a 2015.

Fonte: INCRA/DFQ. Organizado pelo autor.

Para que se crie mais elementos para confirmar a eventual incapacidade e ineficiência do INCRA, para executar os recursos autorizados para as ações de titulação das terras quilombolas, passaremos a observar a capacidade de execução dos recursos por PPA, na expectativa de identificar, se as causas dessa baixa eficiência se devem a eventos pontuais ou se é um fenômeno que se aplica a todo o período, conforme disponibilizado nos Gráficos 17 e 18: 


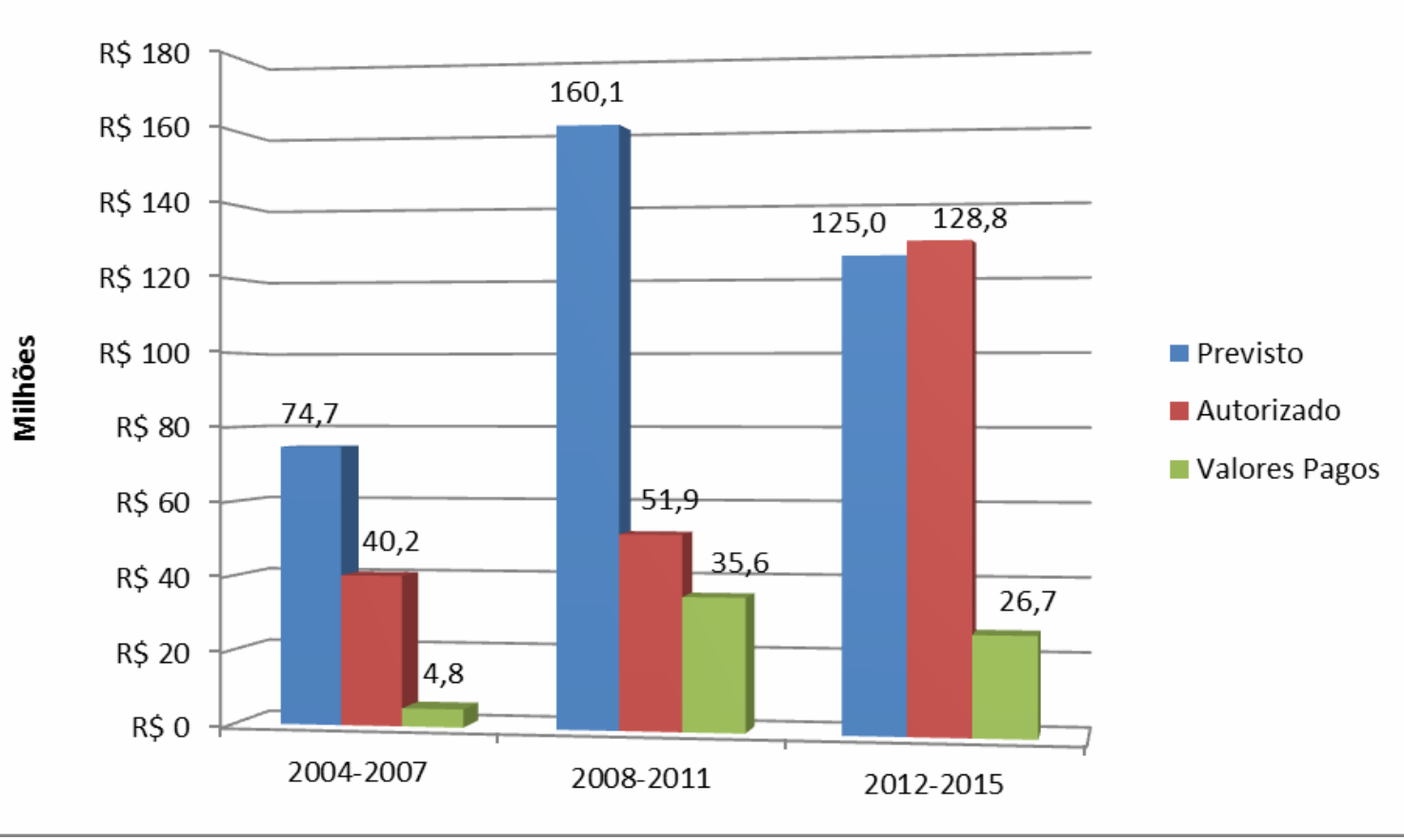

Gráfico 17: DESPESAS DE CAPITAL: Recursos Previstos, Autorizados e Pagos pelo INCRA nas ações de titulação de terras quilombolas, por PPA. Fonte: INCRA/DFQ. Organizado pelo autor.

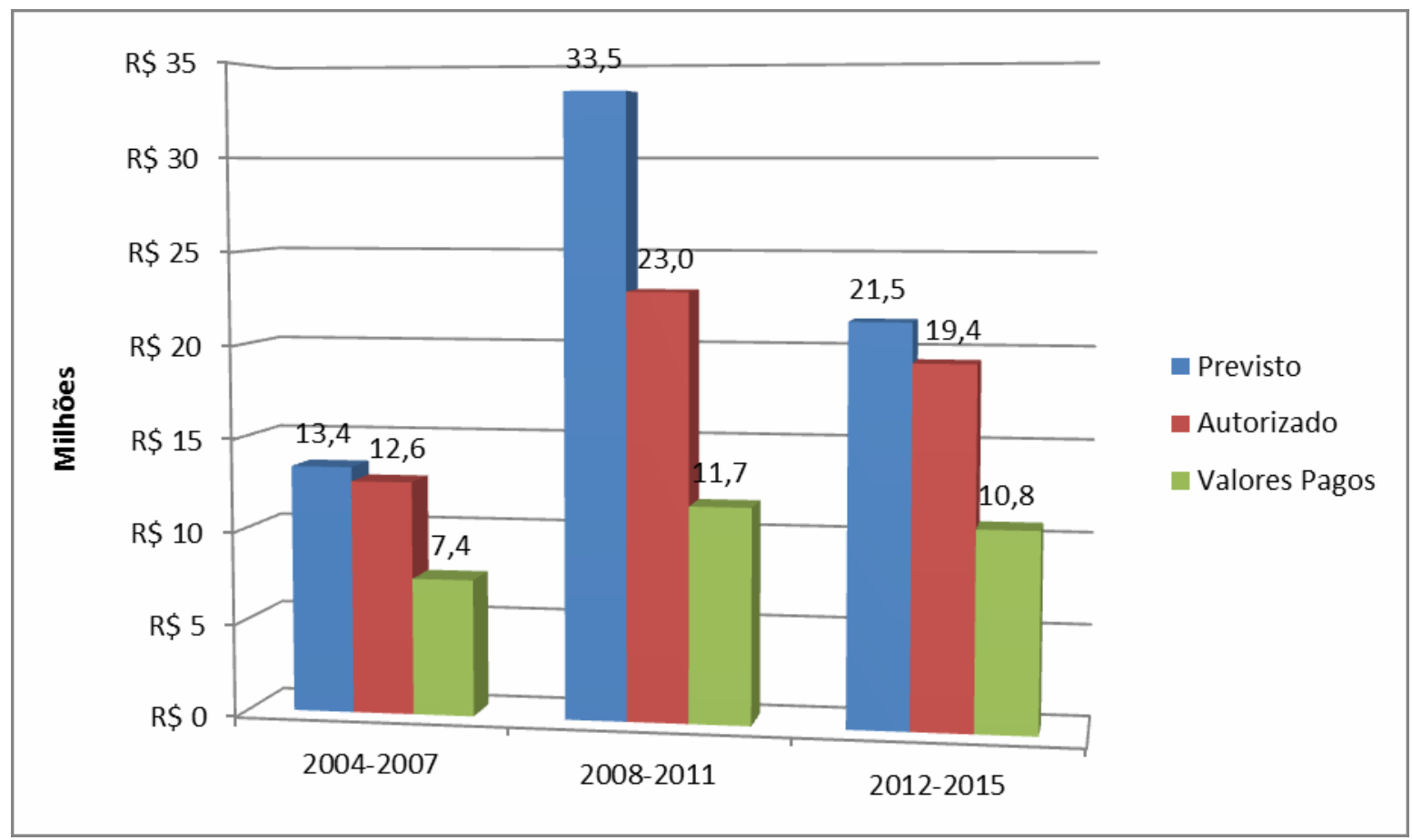

Gráfico 18: DESPESAS CORRENTES: Recursos Previstos, Autorizados e Pagos pelo INCRA nas ações de titulação de terras quilombolas, por PPA.

Fonte: INCRA/DFQ. Organizado pelo autor. 
Nota-se que a dificuldade enfrentada pelo INCRA para executar os recursos previstos e autorizados se fez presente em todos os PPA's analisados e nas duas naturezas de despesa. No que se refere às despesas de capital:

- Apenas $61,4 \%$ dos recursos previstos no orçamento às despesas de capital foram autorizados pelo Governo Federal;

- Apenas $30,4 \%$ do que foi autorizado foi efetivamente executado;

- Apenas $18,7 \%$ do orçamento previsto foi efetivamente executado pelo INCRA.

- O PPA 2008-2011 apresentou a maior discrepância entre o que foi planejado e executado, numa proporção de apenas $22,2 \%$.

No que se refere às despesas correntes, a discrepância também foi identificada nos seguintes valores:

- $80,5 \%$ dos recursos que foram previstos nos orçamentos foram autorizados pelo Governo Federal;

- $54,1 \%$ do que foi autorizado foi efetivamente executado pelo INCRA;

- $\quad 43,6 \%$ do que foi previsto no orçamento foram efetivamente executados;

- Assim como aconteceu com as despesas de capital, foi no PPA 2008-2011 que se constatou a maior discrepância entre o que foi planejado e executado, representando apenas 34,8\%.

Para que seja possível analisar a performance do INCRA, na execução dos recursos com mais profundidade, os dados foram também organizados por exercício financeiro e por PPA, tornando-se assim possível constatar se há uma discrepância significativa de um exercício para outro ou se há uma coerência dentro do próprio PPA. Os dados estão presentes nos Gráficos 19 a 24, que demonstram os valores previstos, autorizados e pagos para as despesas correntes e despesas de capital para cada um dos exercícios do PPA's analisados: 


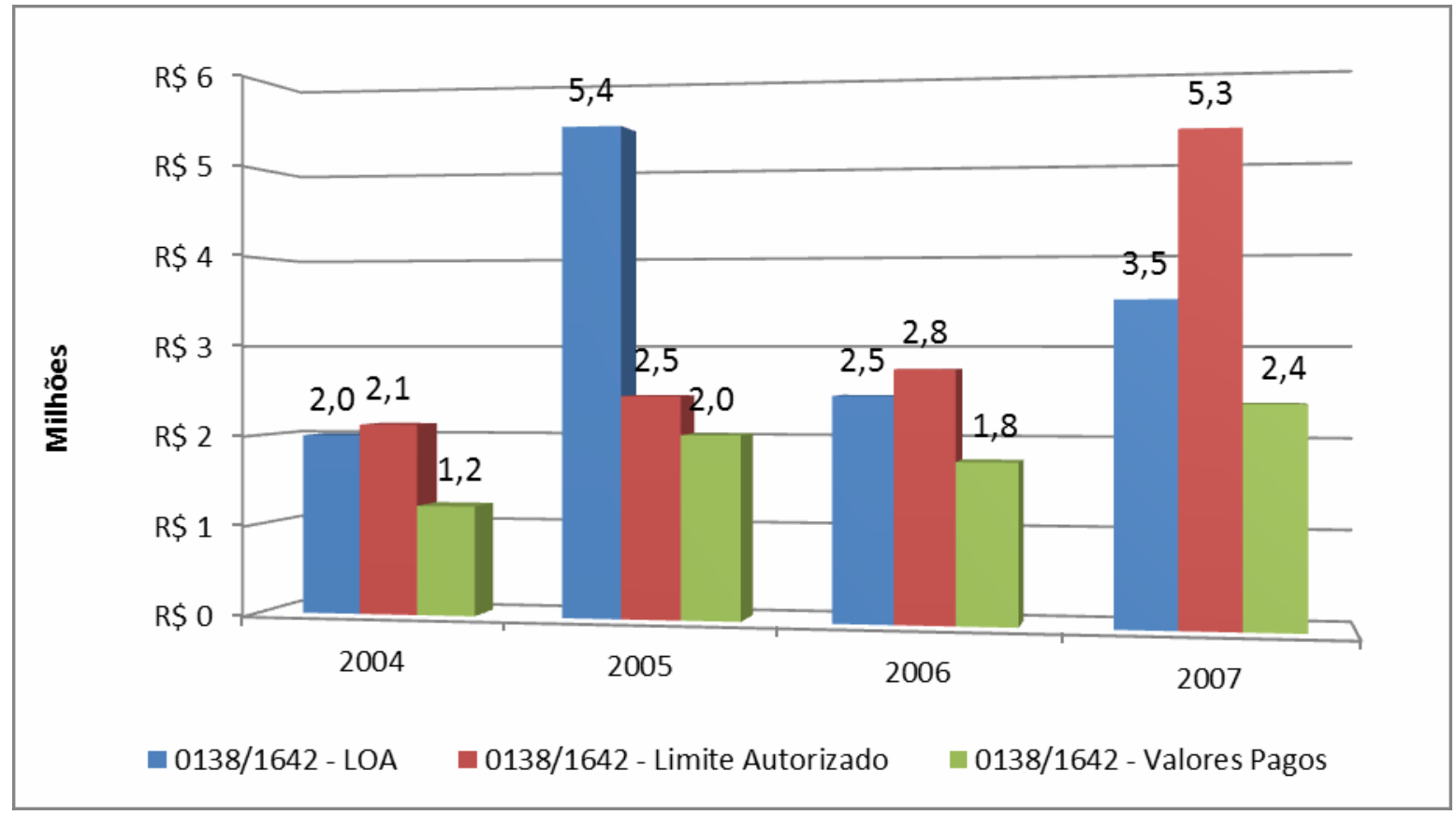

Gráfico 19: DESPESAS CORRENTES: Recursos Previstos, Autorizados e Pagos pelo INCRA nas ações de titulação de terras quilombolas - PPA 2004 a 2007. Fonte: INCRA/DFQ. Organizado pelo autor.

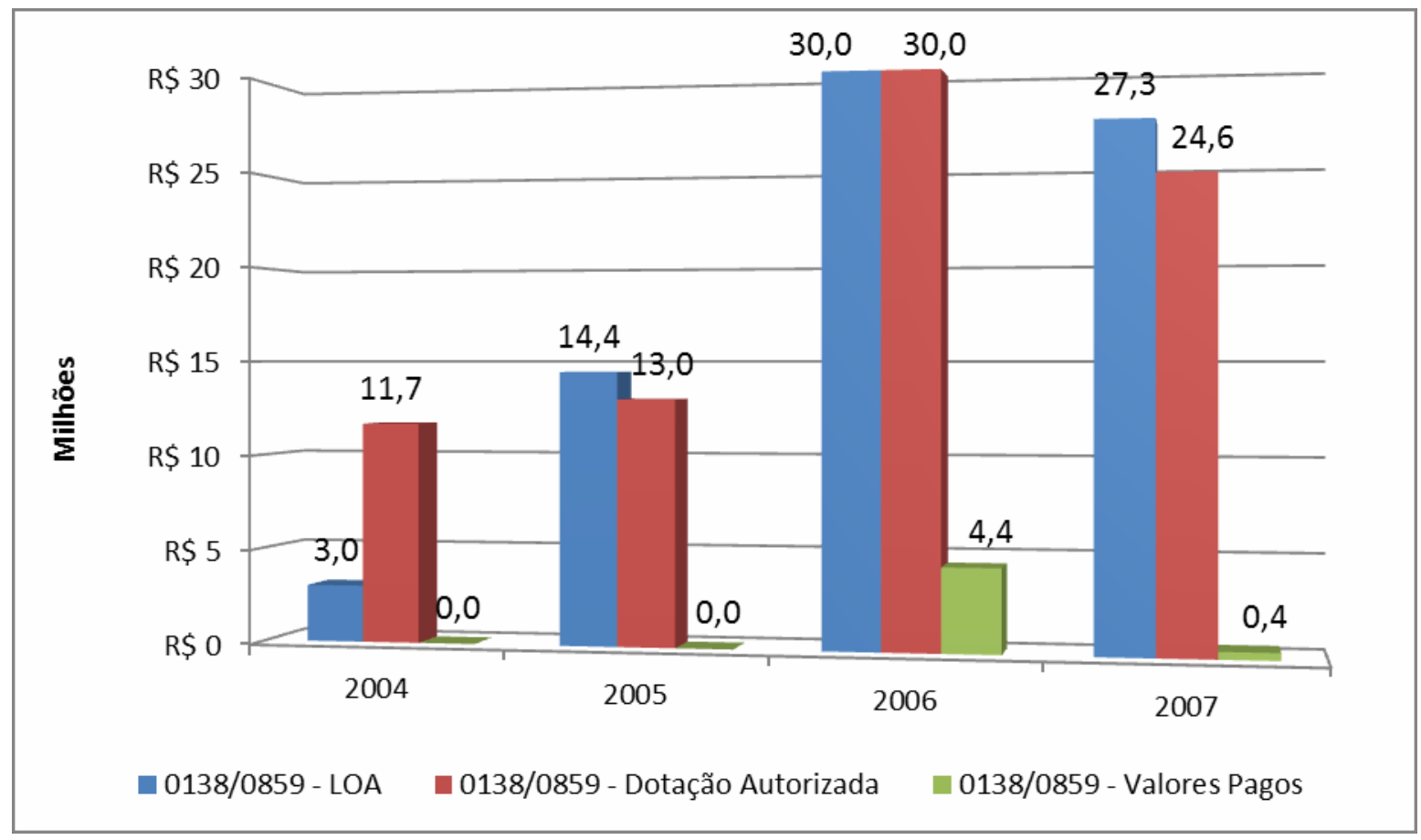

Gráfico 20: DESPESAS DE CAPITAL: Recursos Previstos, Autorizados e Pagos pelo INCRA nas ações de titulação de terras quilombolas - PPA 2004 a 2007.

Fonte: INCRA/DFQ. Organizado pelo autor. 


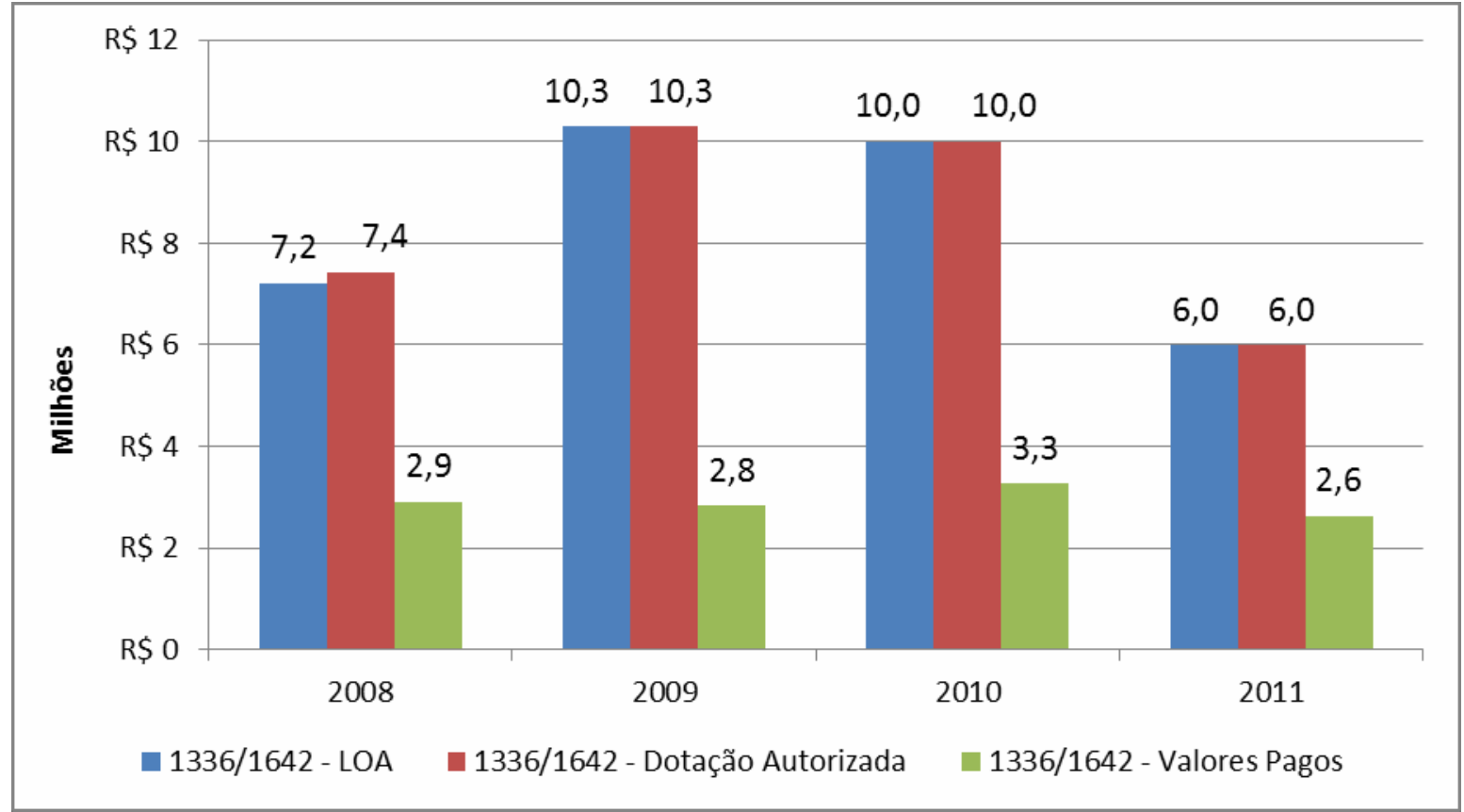

Gráfico 21: DESPESAS CORRENTES: Recursos Previstos, Autorizados e Pagos pelo INCRA nas ações de titulação de terras quilombolas - PPA 2008 a 2011. Fonte: INCRA/DFQ. Organizado pelo autor.

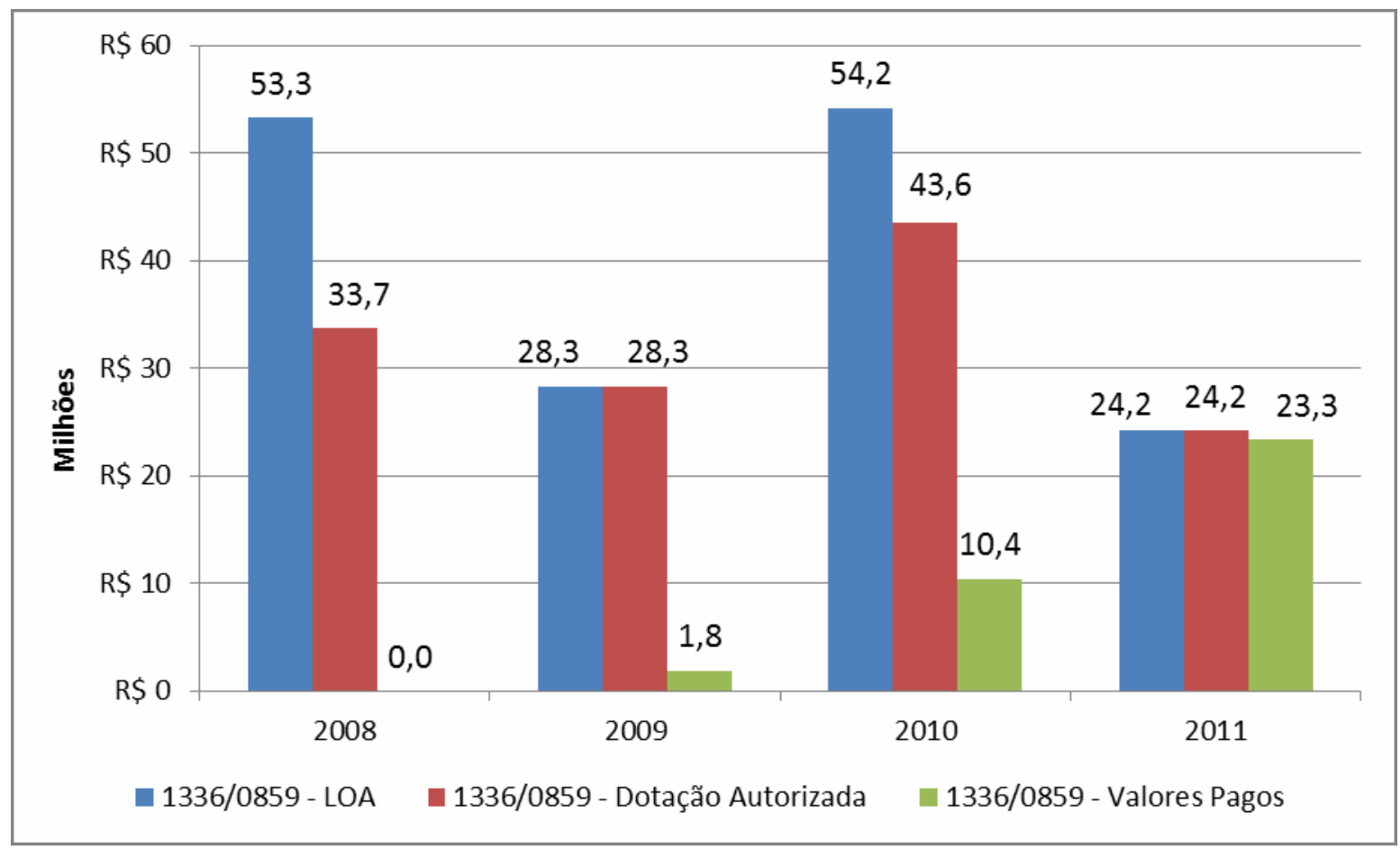

Gráfico 22: DESPESAS DE CAPITAL: Recursos Previstos, Autorizados e Pagos pelo INCRA nas ações de titulação de terras quilombolas - PPA 2008 a 2011.

Fonte: INCRA/DFQ. Organizado pelo autor. 


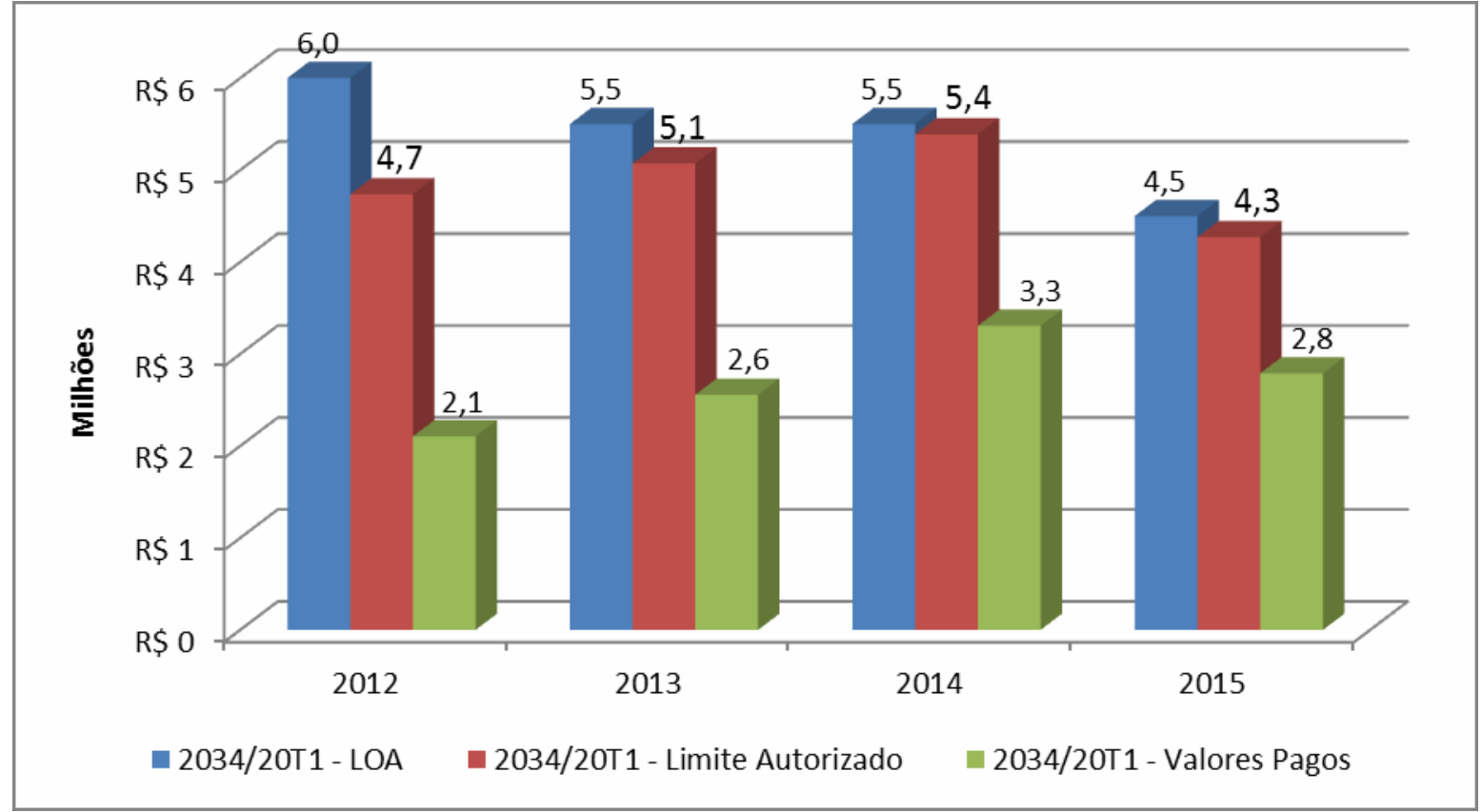

Gráfico 23: DESPESAS CORRENTES: Recursos Previstos, Autorizados e Pagos pelo INCRA nas ações de titulação de terras quilombolas - PPA 2012 a 2015. Fonte: INCRA/DFQ. Organizado pelo autor.

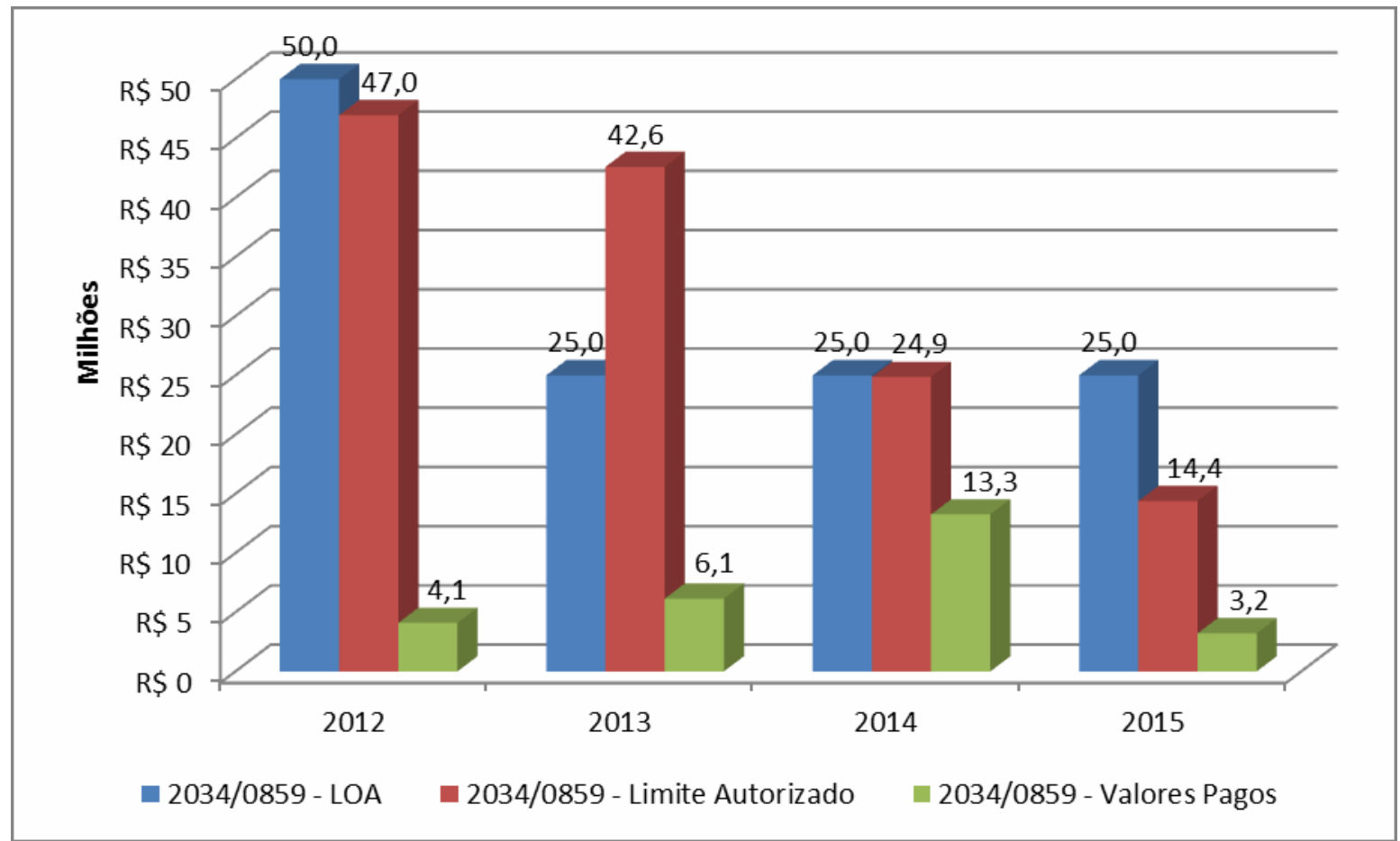

Gráfico 24: DESPESAS DE CAPITAL: Recursos Previstos, Autorizados e Pagos pelo INCRA nas ações de titulação de terras quilombolas - PPA 2012 a 2015.

Fonte: INCRA/DFQ. Organizado pelo autor. 
No que se refere às despesas correntes, a análise dos dados contidos nos Gráficos 19, 21 e 23 indicam o início de uma trajetória de incremento do investimento no programa em 2008 cujo ápice é alcançado em 2011. Contudo, observa-se que, no exercício de 2012, os valores sofrem uma busca redução, estagnando-se nos exercícios subsequentes.

Quanto às despesas de capital (aquisição de imóveis), Gráficos 20, 22 e 24, ressalta-se que a não execução de recursos nos primeiros exercícios analisados, especialmente 2004, 2005 e 2006, é justificada pela impossibilidade técnicoadministrativa de se prover a desintrusão de proprietários e ocupantes não quilombolas num único ano/exercício, pois é necessário superar toda uma burocracia jurídico-administrativa que faz com que o prazo mínimo de finalização desses processos se estenda por dois ou mais exercícios. Essa situação resulta em que os recursos descentralizados para execução em determinado exercício tenham que ser "reservados" para pagamento no(s) exercício(s) seguinte(s), o que se denomina contabilmente como "restos a pagar". Trata-se de um fenômeno que pode ser entendido como um "represamento" de demandas por desintrusão, pois estas vão sendo acumuladas, devido à infinidade de trâmites processuais no âmbito administrativo ou judicial, que envolve a negociação ou contestação de valores, para indenização de benfeitorias ou terra nua desapropriadas por interesse social. À medida que os processos judiciais vão sendo solucionados, o INCRA é imitido na posse do respectivo imóvel e, a partir daí, vão se criando condições, para que as terras sejam finalmente repassadas à posse das comunidades quilombolas.

Feita essa ressalva, nota-se a existência de uma curva ascendente de investimentos, iniciada em 2008, e que atinge seu ápice em 2010. Subitamente, porém, os investimentos na aquisição de imóveis despencaram em 2012, o que reflete de forma substancial nos valores totais investidos naquele exercício. No biênio 2013-14, as despesas de capital iniciam uma nova trajetória de incremento, porém, com valores bem mais modestos se comparados aos anos de 2010 e 2011. No exercício de 2015, porém, esses valores voltam a ser reduzidos drasticamente.

De acordo com os dados de recursos planejados, autorizados e executados pelo INCRA nos PPA's que sucederam à publicação do Decreto 4887 de 2003, constata-se que, seja no âmbito das despesas de capital ou correntes, o INCRA mostrou-se ineficaz e incompetente em executar os recursos que lhe foram 
autorizados pelo Governo Federal, o que refuta a hipótese de que a falta de recursos destinados às ações de titulação de terras quilombolas explique os pífios resultados observados no período. Não significa, porém, que tal fracasso seja uma responsabilidade que se restringe à autarquia federal, mas sim compartilhada por todo o poder público, uma vez que são vários os fatores externos que impediram e ainda impedem que o INCRA execute os recursos com a celeridade que o texto constitucional exige.

\subsection{1 - Análise dos valores executados por família beneficiada, área titulada e localização das terras quilombolas}

Outra variável de fundamental importância, para avaliação da gestão das ações de titulação de terras quilombolas pelo INCRA, deve-se à análise do custo financeiro executado por família beneficiada, pois a variação desse índice pode evidenciar mudanças significativas no paradigma empregado na condução da política.

A análise sobre as despesas correntes por família beneficiada por PPA, indica que os exercícios 2012-15 representaram uma forte ruptura no paradigma/modelo que vinha sendo adotado até então. Essa sentença é comprovada pela queda expressiva do valor médio pago por família beneficiada nesse período, o que representou apenas 20,6\% da média dos PPA's 2004-07 e 2008-11. 


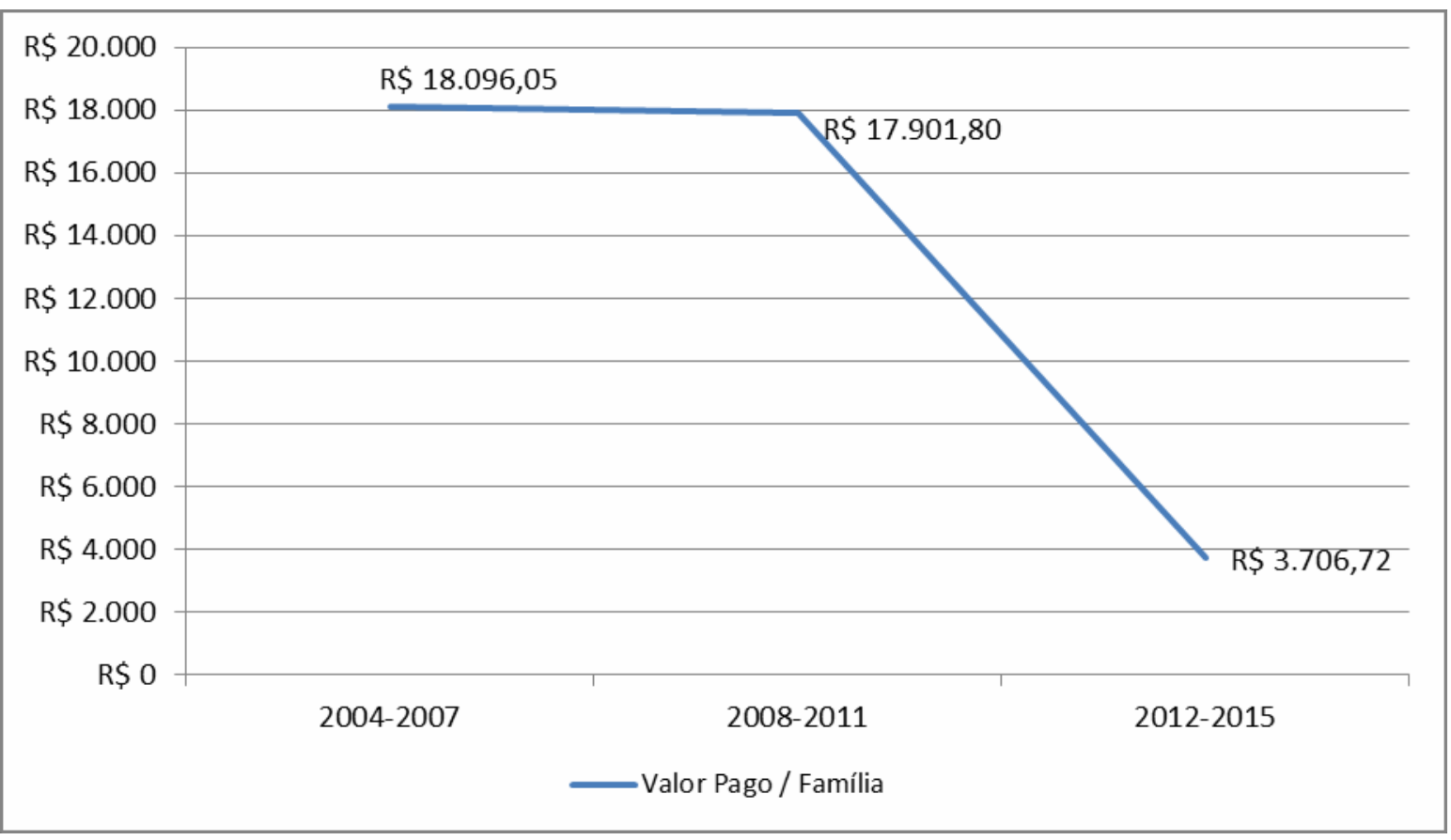

Gráfico 25: INCRA - DESPESAS CORRENTES: Valores Pagos por Família beneficiada, por PPA. Fonte: INCRA/DFQ. Organizado pelo autor.

No que se refere à análise das despesas de capital, convém ressaltar que os custos iniciais para despesas de desapropriação seriam, justificadamente, mais baixas no PPA 2004-07, pois são vários os trâmites burocráticos e judiciais que impedem a conclusão desses trabalhos no mesmo ano/exercício em que é iniciado e, não raro, no exercício seguinte, ocasionando o chamado represamento das demandas por desapropriação. 


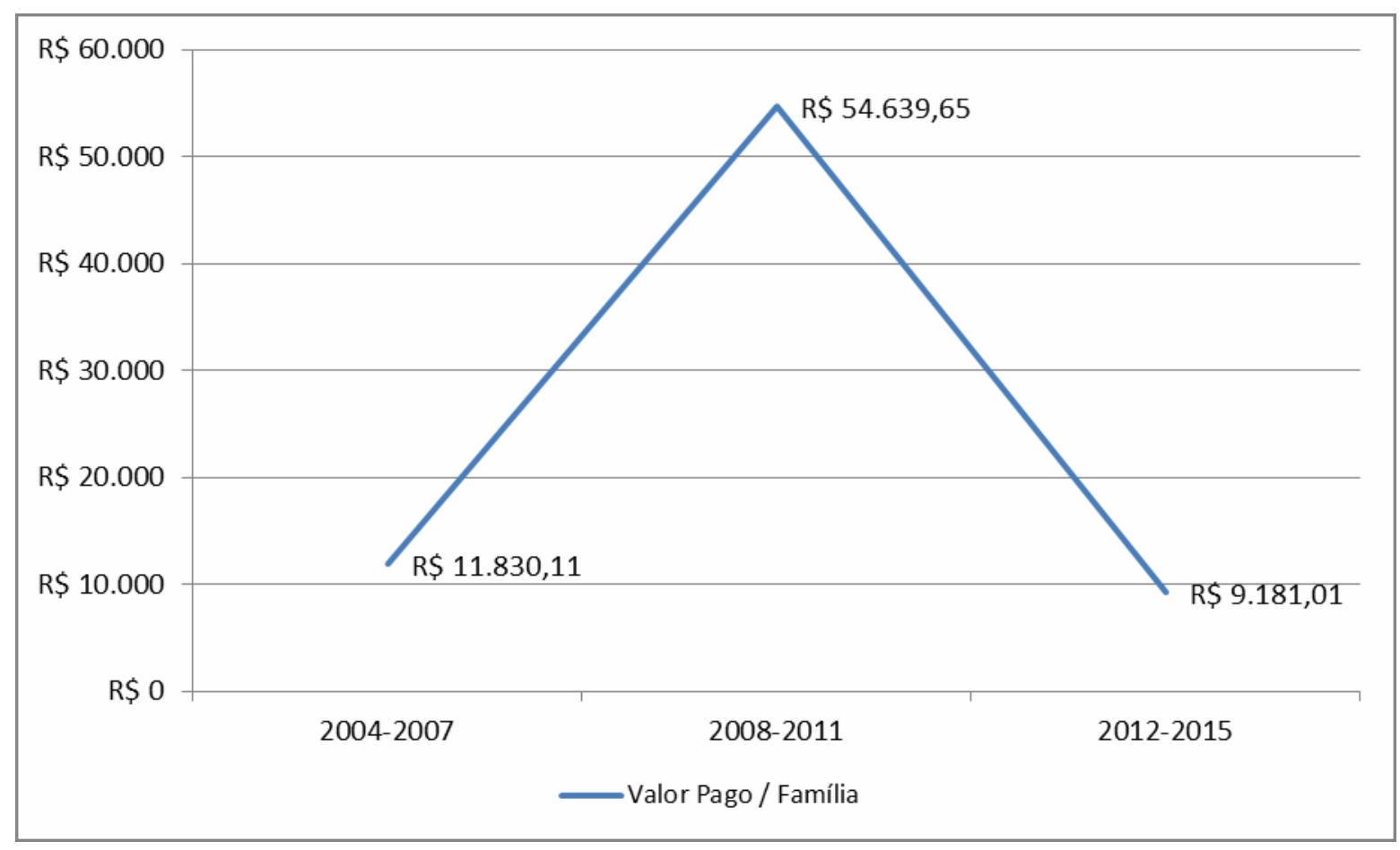

Gráfico 26: INCRA - DESPESAS DE CAPITAL: Valores pagos por Família beneficiada, por PPA. Fonte: INCRA/DFQ. Organizado pelo autor.

Considerando os dados referentes ao PPA 2008-11, observa-se que as despesas de capital pagas por família beneficiada alcançou o valor de $R \$ 54.639,65$, o maior valor em todos os PPA's analisados. Contudo, no PPA 2012-15 esses valores médios alcançaram apenas $R \$ 9.181,01$, ou seja, uma redução de $83 \%$ se comparado ao PPA anterior (2008-11) e 22,3\% menor se comparados ao PPA 200407, que foi de $R \$ 11.830,11$ (desconsideramos em nossos cálculos a inflação do período, o que tornaria o cenário ainda mais crítico).

Curiosamente, quando se correlaciona os custos de capital com a área titulada no PPA 2008-11, percebe-se que o valor do custo médio por família não representou um acréscimo de área titulada de maneira proporcional. O que se nota é o movimento oposto, ou seja, uma redução da área titulada se comparada com o obtido no PPA 2004-07. O PPA 2012-15, porém, que foi aquele em que o INCRA beneficiou o maior número de famílias por PPA, mesmo tendo sido o PPA em que menos se gastou por família beneficiada.

Estas constatações abrem caminho para proposição da hipótese de que as terras que foram adquiridas no PPA 2008-11 eram mais valorizadas comercialmente do que aquelas que foram objeto das ações desapropriatórias em 2004-07, pois 
somente no PPA 2008-11 é que o INCRA passou a titular menos na região Norte e a titular áreas e beneficiar mais famílias nas regiões Sudeste e Sul, que são reconhecidamente regiões em que o valor das terras é mais elevado. No PPA 201215 ocorre um movimento oposto: o INCRA passa volta a titular menos áreas nas regiões Sudeste e Sul e concentra seus resultados, basicamente, nas regiões Nordeste e Centro-Oeste, enquanto que, na região Norte, nenhuma família foi beneficiada e nenhum hectare desapropriado pelo INCRA (conforme discutido anteriormente).

Com base nos dados de cada um dos PPA's, é possível concluir que o INCRA vem desapropriando áreas cada vez menores, ao passo que o número de famílias assentadas por hectare tem aumentado paulatinamente. No PPA 2004-07, essa proporção foi de 66 ha/família; no PPA 2008-11 foi de 27 ha/família e, no PPA 201215 esse valor médio não passou de 04 ha/família. A média de área titulada por família, considerando-se os três PPA's analisados (2004-15), é 14 de ha. Nesse contexto, os gastos de capital por família beneficiada sofreu uma brusca redução a partir do PPA 2012-15, o que nos permite concluir que mais famílias estão sendo beneficiadas em territórios cada vez menores e a um custo cada vez mais reduzido.

\subsection{2 - Aprofundando a análise: Fatores (geo)políticos e sua influência na titulação das terras quilombolas}

Para uma análise mais criteriosa da política em geral e especialmente do fenômeno observado no exercício de 2012, propomos que as informações, referentes aos investimentos executados e dos resultados alcançados no período, sejam analisadas a partir de outras variáveis, como as de natureza políticoinstitucional, econômicas, jurídicas e de infraestrutura administrativa (INCRA).

Um ponto de partida fundamental para essa análise é a investigação a respeito das motivações para a drástica redução dos valores de investimentos em 
aquisição de imóveis, observada a partir do exercício de 2012, interrompendo uma tendência que se iniciou em 2008.

Uma hipótese inicial se baseia no fato de que tal contingenciamento de recursos seria um reflexo das restrições orçamentárias impostas pelo Governo Federal na busca por soluções às sucessivas crises econômicas e financeiras que afetou a economia nacional naquele período. Sob essa perspectiva, assim como várias outras políticas públicas, as ações de titulação das terras quilombolas sofreriam um corte orçamentário sob o argumento da necessidade de equilíbrio das contas públicas. No dia 15 de fevereiro de 2012, o Governo Federal anunciava um corte de $\mathrm{R} \$ 55$ bi no orçamento federal, sendo que destes, $\mathrm{R} \$ 35$ bilhões se referiam aos chamados gastos discricionários que, dentre outras despesas, incluem as diárias, passagens e locomoção dos servidores públicos, o que afeta radicalmente os trabalhos de elaboração de novos RTID's e de procedimentos preliminares à desintrusão de famílias não-quilombolas, que são desenvolvidas, essencialmente a partir do deslocamento das equipes do INCRA à área reivindicada, para elaboração dos relatórios antropológicos, levantamentos fundiários, cadastro das famílias quilombolas, demarcação e georreferenciamento, vistorias de avaliação de imóveis etc., conforme regulamentado pela IN INCRA no57 de 2009. Essa hipótese, contudo, à luz de uma análise mais apurada, torna-se bastante frágil, à medida que se observa que várias outras políticas públicas que envolvem valores orçamentários muito superiores às relacionadas à titulação das terras quilombolas não foram afetadas por nenhum tipo de contingenciamento por parte do Governo Federal, nesse mesmo período como, por exemplo, o Programa de Aceleração do Crescimento (PAC), Minha Casa Minha Vida e Brasil Sem Miséria. Nesse sentido, a consideração dessa hipótese apenas reforça 0 argumento de que 0 contingenciamento dos recursos voltados às ações de titulação de terras quilombolas, ocorrido a partir do orçamento de 2012, deu-se não em decorrência de uma crise econômica que impôs ao Governo a adoção de uma decisão tão drástica, mas sim de uma decisão política arbitrária. Outro aspecto que deve ser considerado é que, para o orçamento de 2011, o governo federal efetuou um corte de $R \$ 50$ bilhões e, apesar disso, este foi o ano em que o PBQ apresentou um dos maiores investimentos anuais, conforme discutido anteriormente.

Analisando-se a proporção de processos sem instrução efetiva no INCRA e os comparando com a execução orçamentária, a fim de se identificar uma eventual 
relação entre essas variáveis, pode-se inferir que os picos de investimento, nos anos de 2010 e 2011, não se relacionam diretamente com essa variável e nem mesmo com o aumento da demanda gerada pela abertura de novos processos, pois além dos novos protocolos estarem dentro da média anual histórica do programa, o aumento de recursos executados, nesses anos, se deu basicamente nas despesas de capital, que é a ação relativa aos procedimentos de desintrusão das famílias nãoquilombolas e que só é executada a partir da publicação do RTID e da consequente assinatura dos Decretos da Presidência da República, declarando a área proposta como de interesse social e objeto de desapropriação, ou seja, constitui-se numa das últimas etapas do processo de titulação de um território quilombola. Observa-se, também, que os valores de despesas correntes, que consistem basicamente na produção de novos RTID's, tiveram um pico de investimento planejado nos exercícios 2009 e 2010 mas apresentou, nos exercícios subsequentes, uma curva descendente, caindo de $\mathrm{R} \$ 10,3$ milhões em 2009 para $\mathrm{R} \$ 4,5$ milhões em 2015.

Isso nos permite concluir que os anos de 2010 e 2011 foram privilegiados, pelo menos em termos orçamentários, para as ações de desintrusão das famílias não-quilombolas, ou seja, retirada das famílias que não pertencem às comunidades via desapropriação ou remanejamento para outras áreas. Em outras palavras, esses exercícios representaram, para o poder público, uma tentativa de se priorizar a demanda por desintrusões represadas nos anos anteriores o que, em tese, poderia abrir caminho para as titulações das comunidades envolvidas. Contudo, nos exercícios subsequentes, de 2012 a 2015, além de representarem investimentos nos procedimentos de desintrusão bem mais modestos, o que se observa é que o quantitativo de áreas quilombolas tituladas pelo INCRA foram bastante escassas, somando $10.517,3$ ha, o que significa uma redução de quase $41 \%$ do que se observou no PPA 2008-11 (17.774,7 ha). Esses dados revelam, portanto, que houve uma nítida quebra de paradigma na condução das ações de titulação das terras quilombolas, o que se confirma pelos pífios números de decretos assinados pela Presidência da República no período. Também é importante ressaltar que o incremento de recursos executados, em 2010 e 2011, nas despesas de capital não representaram um aumento significativo no quantitativo de áreas tituladas nos anos subsequentes.

$\mathrm{Na}$ perspectiva da política-institucional do INCRA, deve-se considerar uma informação que repercutiu, com bastante impacto junto aos movimentos sociais, 
academia, nos vários canais da mídia e no seio das entidades sindicais ligadas ao setor agrário, que tratava da possível "desestruturação do INCRA", processo no qual a autarquia seria minimizada a um papel simbólico, dentro da estrutura do poder executivo ou, no pior dos cenários, seria até mesmo extinta, e suas atribuições distribuídas entre outros órgãos federais ou mesmo a partir de convênios com entidades dos governos estaduais ou municipais.

Apesar de o INCRA não ter sido extinto e a regularização de territórios quilombolas ainda ser uma atribuição desta autarquia, nota-se que, em parte, essa hipótese se mostrou coerente, haja vista que várias atribuições que haviam muitos anos eram desempenhadas pelo INCRA foram realmente remanejadas para outros órgãos, como a política de acesso a créditos para moradia rural (foi criado o Minha Casa Minha Vida Rural), a aquisição de créditos e renegociação de dívidas do PRONAF (passou a ser efetuada em parceria com o Banco do Brasil) etc. Fatos como esses não nos permite refutar, totalmente, a possibilidade de que outras alterações na estrutura do órgão foram consideradas, inclusive a que sustenta a ideia de que as ações de titulação das terras quilombolas deixariam de fazer parte do rol de atribuições do INCRA.

Porém, uma hipótese que nos parece mais sólida tem suas bases fundadas justamente na instabilidade jurídica que sofre o Decreto 4.887 de 2003. Ocorre que, no dia 18 de abril de 2012, o ministro do Supremo Tribunal Federal (STF) César Peluso, relator do processo que julga a constitucionalidade do referido decreto (Ação Direta de Inconstitucionalidade (ADI 3239), proferiu seu voto pela

(...) procedência da ação e, portanto, pela inconstitucionalidade do decreto questionado. Entretanto, "em respeito ao princípio da segurança jurídica e aos cidadãos que, da boa-fé, confiaram na legislação posta e percorreram o longo caminho para obter a titulação de suas terras desde 1988", decidiu modular os efeitos da decisão para "declarar bons, firmes e válidos" os títulos de tais áreas, emitidos até agora, com base no Decreto 4.887/2003.

A possibilidade de "queda" do Decreto 4.887 de 2003 acarretou uma insegurança por parte dos gestores públicos responsáveis pela execução das ações de titulação das terras quilombolas, pois havia o receio de que, uma vez declarado o Decreto como inconstitucional, todos os atos administrativos dele derivados 
poderiam ser revistos ou anulados, o que representaria uma catástrofe políticoadministrativa para o Estado brasileiro e para as comunidades quilombolas em geral, especialmente aquelas que já foram contempladas com seus títulos de domínio. Essa situação fica evidente em 2013, numa fala do então Presidente do INCRA, Carlos Guedes de Guedes, registrada na Ata de Audiência Pública sobre a Ação do MPF na Defesa das Comunidades Quilombolas, realizada em 20 de novembro de 2013, situação em que o gestor afirma que

(...) o Judiciário tem inviabilizado essa solução em alguns casos, citando, em especial, algumas decisões no sentido de que processos têm que ser paralisados porque a ADI não foi julgada. São obstáculos que precisam ser contornados. Acrescentou que estão sendo traçadas algumas estratégias que podem dar resultado a curto e médio prazo, como uma verificação das áreas que estão em terras públicas, e que podem ser solucionadas com maior facilidade.

Fica evidente, na fala do gestor, que a paralisação de "alguns processos" de titulação, pelo menos no período em que presidiu o Instituto, foi uma opção da autarquia federal com vistas ao julgamento da ADI e, a partir dessa situação, foram priorizadas aquelas áreas localizadas em terras públicas que, na fala do Presidente, são de solução mais "fácil”.

Isso confirma o que foi sentenciado pela Nota Técnica INESC 168 de julho de 2010 intitulada Orçamento Quilombola 2008-2010 e a maquiagem na titulação, que chama a atenção para um fenômeno identificado em 22 das 24 titulações de terras quilombolas realizadas no período compreendido entre 2008 e junho de 2010:

(...) de 24 titulações, somente duas foram realizadas pelo INCRA, as demais foram obra dos institutos de terras dos estados. Depoimentos obtidos de técnicos desses órgãos informam que nas titulações realizadas no período, em várias houve parceria entre o órgão federal e os institutos estaduais. Os depoimentos também fornecem elementos que nos levam a concluir que está havendo o que chamamos de uma "maquiagem" no processo de titulação. Estão sendo tituladas preferencialmente as comunidades situadas em "terras devolutas", "terras públicas estaduais" e "terras sem grandes dificuldades de aquisição". Além de deixar de fora a grande maioria da população quilombola, em alguns casos isso tem implicado em áreas tituladas com extensão insuficiente para a reprodução social das famílias e comunidades. (INESC, 2010, p.02) 
O’Dwyer (2014,p. 83) também denuncia esse posicionamento do INCRA, apontando ainda que

O governo, em nome de interesses do Estado, vem levantando uma série de impedimentos para a publicação dos RTID"s e os servidores com habilitação em antropologia têm sido "orientados" pela diretoria de ordenamento fundiário do INCRA para não apresentarem "áreas que deem problema" para o governo. Contrariando a própria Instrução Normativa do INCRA em Memorando Circular (05 do DF/INCRA de 29/02/2013), as superintendências regionais devem encaminhar à Diretoria de Ordenamento da Estrutura Fundiária-DF, uma solicitação de avaliação prévia dos RTID's, o que não está na norma. Além disso, não é necessário o envio do RTID, conforme orientação da presidência através do Memo. 001/2013 e sim a "ficha" de "informações prévias para publicação da RTID", preenchida com todos os dados solicitados. As referidas "fichas" estão condicionadas à aprovação pelo gabinete do presidente do INCRA. Segundo depoimento de um servidor analista em antropologia do INCRA: "Não sabemos quais critérios serão usados para aprovação das fichas, não sabemos nem se tais fichas estão de fato sendo apreciadas". O que é público, segundo ele, "é que esse procedimento não encontra amparo legal e tem sido usado como justificativa para total paralisação das publicações". Em nota, os servidores do INCRA denunciam: "Novas rotinas administrativas, excepcionais, extranorma e que acabam por protelar a efetivação da política pública e da concretização do direito desses grupos ao seu território (...) só vem intensificar os conflitos fundiários e a violência no campo.

Avaliando a baixa performance financeira do Programa Brasil Quilombola nos exercícios 2008 e 2009, INESC (2010) aponta o peso do desempenho do MDA e INCRA, à medida em que alcançaram somente $13,26 \%$ do recurso autorizado em 2008 e 15,02\% do autorizado em 2009. 
A principal ação que pesou nesse resultado foi a de "indenizações aos ocupantes das terras demarcadas e tituladas aos remanescentes de quilombos". Dos cerca de $\mathrm{R} \$ 33,672$ milhões orçados em 2008, nada foi utilizado, retornando para o Tesouro Nacional o valor integral. Em 2009, dos $\mathrm{R} \$ 28,3$ milhões autorizados pelo Congresso Nacional, foram empregados somente 6,52\%. $\mathrm{Na}$ ação de "reconhecimento, demarcação e titulação de áreas remanescentes de quilombo", foram utilizados em 2008 cerca de 55,73\%, de um total autorizado de $R \$ 7,4$ milhões. No ano seguinte, em 2009 , foram gastos apenas $33,46 \%$, de um orçamento de $R \$ 10,287$ milhões. Para se ter uma ideia do que deixou de ser investido, somente em 2009 o montante foi de $\mathrm{R} \$ 6,8$ milhões. (INESC, 2010, p.04)

Ao tentar identificar as causas desse fenômeno de baixa execução financeira dos orçamentos previstos para esse programa, o INESC (2010) aponta, em última análise, para dois pontos principais. O primeiro refere-se ao "extenso, complicado e truncado rito processual, e ainda, ter de esperar pelo „benevolente canetaço' do Presidente da República, assinando o tal Decreto, o que possibilita as desapropriações", combinando com a estratégia de priorizar a titulação em áreas onde a normativa é mais simplificada (leis estaduais mais brandas que as instruções normativas do INCRA). O segundo ponto refere-se à escolha prioritária pela regularização de "terras devolutas" ou "terra pública estadual" ou "em terras sem grandes dificuldades para aquisição":

Evita-se, portanto, o reconhecimento de territórios onde isso possa implicar em confronto com interesses políticos e econômicos locais e regionais. Em última instância, parece haver uma orientação estratégica, vinda do núcleo político governamental, no sentido de evitar, a qualquer custo, a exposição da Presidência da República à situação de ter de assinar um procedimento político-administrativo de desapropriação de terra "conflitante". Ou seja, está se evitando situações que coloquem em risco as "boas" relações políticas, estabelecidas entre as "velhas" e "novas" elites, e a estrutura de alianças que hoje hegemoniza o comando das políticas instituições do Estado e a economia brasileira. (...) optar pelas "terras devolutas", "públicas estaduais" e "terras sem grandes dificuldades de aquisição" como únicas vias de titulação, no nosso entendimento, é tangenciar o problema. É ser conivente com a continuidade das condições de exploração dessas pessoas, os/as quilombolas, como "mão-de-obra barata", vivendo em condições degradantes em não poucos casos, e sob violências de diferentes formas. É maquiar o processo de titulação dos territórios quilombola. (INESC, 2010, p10) 
A fala de INESC (2010) reforça minhas constatações de que o processo de regularização das terras quilombolas se deu em maior medida nas regiões em que o estoque de terras devolutas ou de domínio da União era mais abundante, como é o caso da Região Norte do Brasil, o que dispensa a desapropriação das terras a serem destinadas aos quilombolas, devendo o INCRA proceder apenas a indenização das benfeitorias. Isto não significa, porém, que os resultados alcançados pela autarquia federal nessas regiões são satisfatórios, uma vez que, dentre os processos instaurados na região Norte no PPA 2004-07, em 44 os RTID’s foram sequer concluídos.

Com o pedido de vistas da ministra Rosa Weber, o julgamento dessa ADI foi interrompido, fato que perpetuou nos anos seguintes a situação de instabilidade institucional, alimentada pela possibilidade de declaração de inconstitucionalidade do principal instrumento normativo da política de regularização de territórios quilombolas e a consequente invalidação dos atos administrativos, executados pelo Estado com base nesse decreto.

Assim, conclui-se que esse novo ciclo das ações de aquisição de imóveis, que foram praticamente paralisadas em 2012 e retomadas em patamares muito discretos nos exercícios posteriores, explica-se não apenas pelos obstáculos burocráticos representados pelos normativos para desintrusão das propriedades de não-quilombolas ou das eventuais dificuldades orçamentário-financeiras enfrentadas pelo Governo Federal, mas principalmente pela insegurança dos gestores públicos em promover atos administrativos com base num instrumento jurídico tão frágil como o Decreto 4.887, que optaram por um novo paradigma para as ações, que privilegia a atuação em pleitos que não envolvem custos financeiros e principalmente sóciopolíticos para o Governo, assim como pela baixa capacidade de pressão dos grupos quilombolas junto a "quem governa". Sobre essa questão, os trabalhos de Giacomini (2009), Fiabani (2014), Rodrigues (2010) e Arruti (2009) são representativos para a identificação das forças que se sobrepõem aos interesses quilombolas, notadamente da titulação de suas terras, nas várias etapas de planejamento e execução.

Ao lado da mudança nas normas da FCP e do INCRA, a bancada ruralista no Congresso Nacional conseguiu impor dois novos avanços significativos na campanha contra os direitos quilombolas. De um lado, ela passou a impor forte resistência em aprovar o Estatuto da Igualdade Racial se ele continuasse incluindo o artigo relativo à 
regularização dos territórios quilombolas em sua formulação alinhada ao decreto 4788/2003. Em resposta a isso, a Seppir de fato, cedeu e, tendo em vista o objetivo de aprovar o Estatuto antes das próximas eleições, propôs a retirada do artigo problemático, ainda que em desacordo com as propostas do MDA. De outro lado, o advogadogeral da União, José Dias Tóffoli, emitia depoimento à imprensa oficial no qual declarava ter "o mesmo entendimento" que o líder da bancada ruralista na Câmara sobre a demarcação de terras quilombolas em ao menos um ponto: só terras "efetivamente ocupadas" pelas comunidades são passíveis de titulação pelo Incra. Este foi o sinal para que o deputado ruralista anunciasse a apresentação à $A G U$ de um novo pedido de revisão do "decreto quilombola". Portanto, a conjuntura aberta em 2007 (e ainda de desfecho indefinido, no momento de redação deste texto) segue marcada por um movimento em que se podem identificar ao menos três frentes de ataque à política fundiária de efetiva regularização dos territórios quilombolas: no Supremo Tribunal Federal, onde se questiona a constitucionalidade do decreto 4788/2003, na incorporação pela própria AGU (que por princípio teria a função de defender 0 decreto presidencial) dos argumentos contrários às definições de "território", "ocupação" e "autoatribuição" presentes no decreto e, finalmente, no movimento que, no trânsito entre o executivo e o legislativo, antecipa-se na exclusão destes mesmos conceitos do texto final do Estatuto da Igualdade Racial. (ARRUTI, 2009, p.91)

O trabalho de Arruti (2009) abre caminho para propormos os seguintes questionamentos: os grupos quilombolas, desde a previsão constitucional de seus direitos territoriais, podem ser classificados como atores "com quem se governa" e "para quem se governa"? Por que o destaque à mobilização política em torno da "causa quilombola" cresce significativamente nos anos em que ocorrem as eleições majoritárias, tais como no ano de 2006, como referido por Rodrigues (2010)? Estaria a representatividade político-partidária tradicionalmente ligada às demandas fundiárias quilombolas, atuando efetivamente pela reversão do quadro de apatia das ações de titulação de suas terras ou essa representatividade político-partidária, no fim das contas, está mais alinhada à manutenção dos interesses de "quem governa"?

A resposta a essas provocações se torna ainda mais relevante, à medida que consideramos que o alinhamento dos vetores políticos que se organizam em torno da causa quilombola (deputados, senadores, administração direta, especialmente) tende a resultar muito mais em repercussões no plano retórico, que enriquecem estrategicamente os discursos partidários em épocas de campanha eleitoral, mas 
que pouco se convertem em resultados práticos e concretos para as comunidades, como efetiva pressão para aumento da eficácia e eficiência das ações de garantia da segurança fundiária às comunidades quilombolas.

Isso acontece, em nossa compreensão, porque esses vetores políticos também estão alinhados a outros setores indispensáveis à sua perpetuação no poder (com quem se governa). Dessa forma, é nítida a dificuldade de se estabelecer de forma clara e precisa se as populações quilombolas realmente estão inseridas dentre os grupos sociais que podem ser classificados como "para quem se governa" na ótica do Governo e de sua base de sustentação ("quem governa" e "com quem se governa"). Arruti (2009) sintetiza muito bem esse cenário ao refletir que

(...) o avanço da questão quilombola, assim como as reações contrárias a que ele deu lugar, se materializam em um comportamento ambíguo e oscilante do Governo Federal: de um lado, o governo faz previsões orçamentárias generosas para a implantação de políticas públicas e as anuncia com grande alarde, mas, de outro, os ministérios simplesmente não gastam tal orçamento, executando parcelas mínimas das atividades previstas. De um lado, a legislação nacional cria novas figuras de direito (que permitem a emergência de novos movimentos sociais) assim como incorpora leis (por meio da assinatura de diversos acordos e convenções internacionais) que estão entre as mais progressistas do mundo. De outro lado, o executivo cria normas menores, internas às agências de Estado responsáveis por executar tais leis, que estabelecem processos demorados e repletos de obstáculos técnicos e administrativos, enquanto o judiciário reinterpreta tais conceitos de forma restritiva à aplicação de tais direitos, tornando o julgamento dos conflitos que envolvem os movimentos sociais um "eterno retorno" hermenêutico. Assim, a execução orçamentária parcial (em alguns casos ínfima) das políticas públicas para quilombos faz par com dispositivos normativos e judiciários, assim como com novas tentativas de restrição ou mesmo de desconstituição legal dos quilombolas como sujeitos de direitos. (ARRUTI, 2009, p.109)

Atualmente, aproximadamente 10 anos após a publicação dessa obra, a fala de Arruti ainda é bastante atual. Por outro lado, há que se ressaltar que o fracasso das ações de titulação das terras quilombolas está intimamente relacionado ao atendimento dos interesses de outros grupos contrários a essas demandas, seja de forma direta - como por exemplo, aqueles ligados à bancada ruralista ou do agronegócio (Treccani, 2006; Arruti, 2006; Silva 2012; Isa, 2016) ou à ecologia 
preservacionista (Diegues, 2001); de forma indireta, como o movimento dos semterra e das ações de regularização das terras públicas, especialmente na Amazônia Legal - Terra Legal. Sobre esse ponto, Fiabani (2014, p.72) assevera que

Até a data de 31 de maio de 2012, o INCRA expediu 121 títulos em 109 territórios, atendendo 190 comunidades negras, beneficiando 11.946 famílias, distribuídas em 988.356,6694 ha, com a média de 82,7353 ha por família. Somente em 2011, o mesmo INCRA assentou 21.021 famílias não pertencentes às comunidades negras. Ou seja, em um ano, o INCRA assentou praticamente o dobro de famílias tituladas em 23 anos de vigência do artigo 68 do ADCT.

Giacomini (2009, p15) sintetiza seu diagnóstico, afirmando que

\begin{abstract}
Nas últimas décadas, apesar das dificuldades na esfera oficial para o reconhecimento do direito tradicional, "costumeiro", vem sendo estabelecida uma série de legislações, tanto internacional como nacional, estadual e municipal acerca dos direitos das comunidades tradicionais e seus territórios. Contudo, inúmeros obstáculos têm surgido para a efetivação da titulação das terras, entre eles estão os problemas administrativo-burocráticos do estado, as limitações de recursos e, principalmente, o poder dos grupos historicamente apoiados no monopólio da terra, das corporações nacionais e internacionais ligadas ao agronegócio e seus representantes no governo (judiciário e parlamento).
\end{abstract}

Todas essas considerações nos levam a concluir que as demandas quilombolas, se observadas pelas sistemáticas instituídas pelos Decretos 3.912 de 2001 e 4.887 de 2003, não podem ser classificadas como oriundas de grupos sociais situados e consolidados na esfera "para quem se governa", pois seus interesses enquanto grupos sócio-políticos se perdem na vastidão dos demais interesses que pressionam os mesmos representantes políticos de que são base.

Para seus ditos "representantes políticos" que, em muitos casos, ocupam cargos de gestão no seio do próprio Governo, a prioridade não é exatamente o cumprimento das demandas dessas comunidades tradicionais, mas reunir condições de se elegerem ou cooperarem para a eleição de seus "padrinhos políticos" nas próximas eleições. Para isso dependem, direta ou indiretamente, das contribuições estratégicas de setores que, se não necessariamente contrários às causas quilombolas, pelo menos competem pelo controle da agenda do Governo, cada um 
objetivando a priorização de suas demandas e a consequente destinação de recursos orçamentários, financeiros e de execução à sua própria causa.

Essa constatação abre caminho para a retomada da fala de Ruckert (2010), uma vez que reconhecemos as ações de titulação das terras quilombolas como instrumentos de uso político e econômico do território apropriados pelo Estado. Nesse contexto, o reconhecimento dos limites tradicionalmente identificados e delimitados é a expressão soberana do Estado e, a outorga dos títulos às comunidades, a materialização geográfica da territorialidade dessas populações tradicionais, além de se constituírem como símbolos da reparação de injustiças sociais a que foram historicamente acometidas e resultado de sua resistência e luta social e política enquanto grupos sociais com identidade e trajetória histórica peculiar. No âmbito da Geografia Política, a análise do papel do Estado brasileiro e dos entraves que impedem o reconhecimento dessas territorialidades remetem às falhas no que Ruckert (2010, p.18) denominou como estratégias de intervenção do Estado na estrutura, no ordenamento e desenvolvimento territorial. Isso se deve, sobretudo, ao fato dessas políticas não terem superado a dependência das conveniências administrativas e ideológico-partidárias dos grupos políticos que controlam setores do Poder Executivo e postos estratégicos na Administração Pública Federal, especialmente naqueles que tem a prerrogativa da discricionariedade.

Em minha constatação, realizada a partir da análise do processo histórico de efetividade dessas ações e da posterior comprovação empírica das hipóteses levantadas inicialmente, é evidente que, nas disputas geopolíticas travadas pelos mais diversos atores para o controle de frações estratégicas do território nacional, os interesses das comunidades quilombolas foram relegados pelo Governo (quem governa) a um papel marginal. Em outras palavras, não foi criado espaço na agenda pública e nem organização efetiva das próprias entidades que representam os interesses das comunidades tradicionais para que as demandas quilombolas ocupassem papéis de destaque como, por exemplo, aquele representado pelas grandiosas intervenções em infraestrutura anunciadas no Programa de Aceleração do Crescimento (PAC) a partir de 2003 ou mesmo, dos demais movimentos de luta pela terra, como os inúmeros movimentos de trabalhadores sem-terra, cujas pautas se dão também no seio do próprio INCRA. Recorro, complementarmente, às 
constatações de C (2016, p.151) que, ao avaliar as tecnologias de governo voltadas à regularização de terras quilombolas no Recôncavo Baiano, define que:

\begin{abstract}
A análise dos conflitos vivenciados pelas comunidades remanescentes de quilombos do Recôncavo no decorrer dos seus processos de regularização territorial demonstra que, apesar da existência de tecnologias de governo especificamente voltadas para a questão, não há garantias de que os pleitos dessas coletividades sejam atendidos e seus direitos respeitados quando estão em jogo interesses de grandes proprietários de terras e empreendimentos privados de interesse estatal. Como vimos, na Baía do Iguape se sobrepõem três modalidades de políticas públicas promovidas pelo Estado brasileiro: a de conservação do meio ambiente, que resultou na criação da reserva extrativista, a da regularização dos territórios quilombolas e a de incentivo a indústria naval com vistas à exploração do pré-sal. É possível observar uma hierarquia entre elas que possibilita que a última influencie fortemente na condução das demais, a despeito da mobilização contrária dos grupos, movimentos sociais que os apoiam e Ministério Público Federal.
\end{abstract}

Em última análise, pode-se concluir que titular as terras quilombolas tem sido um posicionamento retórico, defendido pelos representantes políticos desses grupos no parlamento e no executivo (quem governa), mas que só se converte em resultados práticos (títulos de domínio das terras), quando interesses de outros grupos sociais (com quem se governa) não são contrariados. Complementarmente, compreendo que se resignar frente à instabilidade jurídica do Decreto 4887 tornou-se um conveniente trunfo retórico de "quem governa" para justificar sua morosidade na execução dessas ações, haja vista que, se utilizando dessa justificativa e não trabalhando efetivamente para superá-la, criou um ambiente propício para a postergação dos de conflitos fundiários que colocariam o próprio Governo em oposição a grupos de pressão "com quem se governa" mas sem, contudo, resolver efetivamente as demandas quilombolas.

Por fim, devemos salientar que o julgamento da ADI 3239 foi retomado em 2015, com a declaração do voto da ministra Rosa Webber pela constitucionalidade do Decreto. Em seguida, o ministro Dias Tóffoli pediu vistas do processo, o que mais uma vez interrompeu o julgamento por um prazo indeterminado e que não foi retomado até o fechamento deste trabalho. 


\section{4 - Titulação das terras quilombolas no PPA 2016-19}

As ações de titulação das terras quilombolas nos primeiros exercícios do PPA 2016-19 foram diretamente impactadas pela instabilidade político-administrativa decorrente do processo de impedimento a que foi submetida a então Presidente da República Sra. Dilma Rousseff.

Essa constatação é fundamentada a partir de duas premissas básicas: a primeira consiste no fato de que apenas um território quilombola foi titulado pelo INCRA no conturbado exercício de 2016. Trata-se da Comunidade Tabacaria, no município de Palmeira dos Índios, em Alagoas. Foram 89 famílias beneficiadas, numa área de 400,0181 ha, cujo título foi outorgado em 20 de novembro de 2016. Para efeito de comparação, em 2015, foram emitidos 04 títulos e, em 2014, 08.

O outro fato que merece destaque é que, dos 05 decretos de desapropriação das áreas reivindicadas pelos quilombolas em 2016, 04 foram emitidos no dia 04 de abril, ou seja, apenas 13 dias antes da Assembleia na Câmara dos Deputados que culminou com o afastamento da Sra. Dilma Rousseff (17 de abril de 2016). As comunidades beneficiadas por esses atos foram:

- Gurupá, município de Cachoeira do Arari (PA), com área de 10.026,1608 ha e 149 famílias beneficiadas;

- Monge Belo, município Anajatuba e Itapecurum Mirim de (MA), com área de $7.246,6129$ ha e 257 famílias beneficiadas;

- Macambira, município de Lagoa Nova, Santana do Matos e Bodó (RN), com área de 2.589,1695 e 263 famílias beneficiadas;

- Caraíba e Adjacências, municípios de Canhoba, Aquidaba, Ceabra de São João, Telha e Amparo de São Francisco (SE), com área de 3.085,3014 ha e beneficiando 130 famílias.

Outro ponto que deve ser destacado neste contexto conturbado é que o debate acerca da condição quilombola e o papel do Estado no processo de reconhecimento desta identidade se tornou ainda mais presente na vida política 
brasileira, tanto que constituiu num dos alvos da Comissão Parlamentar de Inquérito (CPI) na Câmara dos Deputados, cujo relatório sugere o indiciamento de servidores do INCRA, que são alvos de suspeitas de agir sem imparcialidade e impessoalidade em processos de regularização de terras quilombolas no Rio Grande do Sul. As acusações são graves e merecem o amplo direito de defesa e do contraditório, mas também servem para escancarar um problema que aflige os próprios servidores da autarquia há anos e se reflete nitidamente na baixíssima eficiência do INCRA na garantia das populações quilombolas e que foram apontados exaustivamente nesta pesquisa: falta consistência metodológica, rigor conceitual científico para estabelecer parâmetros firmes e objetivos para a definição da dita condição quilombola e da definição de seus respectivos territórios.

Contudo, o fato mais relevante para a análise das ações de titulação das terras quilombolas nesse período se materializou em 18 abril de 2017. Trata-se da informação veiculada pelo jornalista João Fellet, do Portal BBC Brasil, que assinou e publicou a matéria intitulada "Governo Temer trava demarcações de áreas quilombolas".

O jornalista destaca em seu texto que teve acesso a um ofício em que a Casa Civil da Presidência da República teria determinado a devolução de todos os processos relacionados à titulação de terras quilombolas à Secretaria Especial de Desenvolvimento Agrário (SEAD), antigo MDA, fundamentando tal decisão na insegurança jurídica representada pelo não julgamento do Decreto 4.887 de 2003, alvo da ADI 3239. O ofício recomenda, portanto, aguardar o desfecho do julgamento para que se confirme a legalidade da demarcação de áreas quilombolas.

Não há posicionamento oficial da Casa Civil ou da SEAD a respeito da matéria. Mas cabe salientar que, até o fechamento deste texto, o INCRA havia publicado 07 RTID's e 05 Portarias no exercício de 2017, todas anteriores à data da matéria publicada pela BBC Brasil.

Caso seja confirmada a decisão da Casa Civil da Presidência da República em não publicar Decretos de desapropriação de terras para destinação às comunidades quilombolas enquanto não se finalize o julgamento da ADI 3239, compreendo que haverá um importante impacto negativo à garantia dos direitos constitucionais das comunidades quilombolas, pois não há previsão para que o STF retome o julgamento e, em tese, até que ele se conclua, os direitos das 
comunidades estarão sendo negligenciados pelo Governo Federal.

Compreendo ainda que o Governo Temer deveria buscar alternativas para superar a fragilidade jurídica do Decreto 4.887 de novembro de 2003 submetendo, por exemplo, um Projeto de Lei ao Congresso Nacional para pacificar a matéria ao invés de se render, estratégica e comodamente, a essa fragilidade, como fizeram os governos Lula e Dilma. 


\section{CAPÍTULO V: As ações de titulação das terras quilombolas no Amapá: do reconhecimento de direitos à gestão de conflitos}

A abordagem geopolítica abaixo da escala do estado e a avaliação de políticas públicas territoriais preveem, dentre outros aspectos, a consideração do contexto local e regional como estratégias metodológicas fundamentais para 0 reconhecimento de particularidades que, a depender de suas características, podem influenciar positiva ou negativamente a execução das intervenções territoriais. Isto se explica pelo fato de que as relações de poder territorial locais são extremamente importantes para a interpretação dos fatos políticos que interferem no quadro fundiário e no ordenamento do território analisado. No caso da titulação das terras quilombolas, o Amapá se destaca pela elevada ocorrência de comunidades quilombolas, especialmente se considerados os números de comunidades tradicionais afrodescendentes identificadas e catalogadas pela SEAFRO/AP e, por outro lado, pelo fato de que grande parcela do território amapaense se encontra sob domínio federal e constituem-se glebas de terras ainda não destinadas ou devolutas, ou seja, constituem-se em terras públicas da União sob jurisdição do INCRA.

O objetivo principal deste capítulo é estabelecer uma análise das ações de titulação das terras quilombolas no Amapá a partir destas premissas, tendo como foco a gestão dos impactos decorrentes da execução desses trabalhos, sobretudo, a partir dos conflitos fundiários e institucionais gerados no seio da Administração Pública Federal. Neste sentido, será realizada uma síntese do processo histórico de formação do território amapaense, estabelecendo como recorte temporal o período compreendido entre a criação do Território Federal ao Estado do Amapá. Também será investigado o papel do Estado Brasileiro na constituição e gestão do território amapaense a partir do interesse geopolítico estratégico vislumbrado neste estado do extremo norte brasileiro. Também constituem como objetivo deste capítulo realizar um histórico das ações de titulação de terras quilombolas no Amapá, bem como reconhecer o quadro atual em que se encontram essas ações no estado e dos conflitos territoriais que envolvem as comunidades étnicas afrodescendentes. Por fim, será demostrada a problemática representada pelo processo imbricado de 
transferência das glebas de terras federais para o Estado do Amapá e suas consequências para as ações de titulação de terras quilombolas.

No que se refere aos aspectos metodológicos que subsidiaram a discussão, destaca-se os seguintes procedimentos:

- Revisão da literatura científica cujo objeto se volte ao histórico e análise da questão fundiária no Amapá, especialmente no âmbito da questão quilombola;

- Coleta de depoimentos de agentes da administração pública federal e da sociedade civil, que atuam na gestão fundiária das terras reivindicadas pelas comunidades quilombolas. Os depoimentos se deram, prioritariamente, via entrevista semiestruturada com registro de áudio. Quando a realização da entrevista não foi possível nesses moldes, optou-se por sua realização, via correio eletrônico e/ou contato telefônico;

- Análise de documentos cedidos pelas autarquias federais envolvidas e/ou disponibilizadas em sítios eletrônicos da rede mundial de computadores, especialmente INCRA, FCP e ICMBio;

- Identificação e análise de documentos, relatórios e manifestações expedidas pelo MPF/AP e disponibilizadas em sítios eletrônicos da rede mundial de computadores e/ou gentilmente cedidos a esse pesquisador.

Dentre os atores que se propuseram a cooperar com essa pesquisa com seus dados e opiniões, destacamos a fala da Sra. Hildma, presidente licenciada da CONAQ/AP, cujo encontro seu deu na cidade de Macapá, na sede do Sindicato dos Servidores Públicos do Amapá (SINDSEP/AP), onde a Sra. Hildma também atua como liderança sindical.

Como representante da Comissão Pastoral da Terra no Amapá (CPT/AP), foi realizada uma entrevista nas dependências da Igreja de Jesus de Nazaré (Macapá) com o Padre Sisto Magro, que atua há vários anos, nos conflitos fundiários que envolvem as comunidades tradicionais no Amapá, assim como os assentados da reforma agrária e demais atores sociais envolvidos.

Em relação às instituições oficiais, realizou-se uma entrevista com o ex-Chefe 
da Divisão de Ordenamento da Estrutura Fundiária e atual Chefe do Serviço de Regularização de Territórios Quilombolas do INCRA no Amapá, Sr. Mateus Francisco Pagliarini, que nos recebeu gentilmente na sede regional daquela autarquia.

Todas essas entrevistas foram realizadas entre os dias 22 e 29 de março de 2017.

\section{1 - Síntese do processo histórico de formação do território amapaense: Da criação do Território Federal ao Estado do Amapá}

O entendimento da questão quilombola no Amapá, especialmente no que se refere à análise e avaliação das ações de titulação das terras tradicionais, está diretamente vinculada à compreensão do processo histórico, que convergiu no quadro fundiário atual do Amapá. Para subsidiar nossa discussão, a investigação foi organizada, a partir de três recortes temporais básicos, que têm como fatos históricos fundamentais:

a) a criação do Território Federal do Amapá (Decreto-Lei 5.812 de 13 de Setembro de 1943);

b) a promulgação da Constituição Federal de 1988;

c) Decreto $n^{\circ}$ 8.713, de 15 de Abril de 2016, que trata da transferência, ao domínio do Estado do Amapá, as terras pertencentes à União.

Entendemos que, a partir desses diplomas legais, ocorrem os eventos mais relevantes para a configuração do ordenamento fundiário, que se observa atualmente no Amapá.

O Território Federal do Amapá (Decreto-Lei no 5812 de 13 de setembro de 1943) foi criado por ato do então Presidente da República o Sr. Getúlio Vargas, no contexto da Segunda Guerra Mundial (1939-45). Porto (2005) identifica na criação desse Território não apenas uma função de cunho administrativa, mas também considera como fundamentais as suas relações políticas, econômicas e sociais, sob a tutela da União. 
Desmembrado do Pará, o Território Federal do Amapá teve sua área organizada a partir dos municípios de Almerim, pelo seu distrito de Arumanduba, Mazagão (a união dessas duas áreas originaram 0 município de Mazagão), Macapá e Amapá. A partir de então, passou por reestruturações territoriais municipais resultantes de: preocupações geopolíticas (Oiapoque), atuação de empresas nas suas áreas (Santana, Laranjal do Jari, Pedra Branca do Amapari, Serra do Navio, Porto Grande e Vitória do Jari), pela exploração aurífera (Calçoene), pela construção da Usina Hidrelétrica de Coaracy Nunes (Ferreira Gomes) e de movimentos políticos locais (Tartarugalzinho, Cutias, Itaubal, e Pracuúba). (PORTO, 2005, p. 11.987)

O Território Federal tinha seus governadores e prefeitos indicados diretamente pelo Presidente da República e aprovados pelo Senado Federal e constituía-se, portanto, numa extensão do poder central sediado na capital federal, o que permitiria um controle direto sobre decisões estratégicas, conforme aquelas destacadas por Porto (2005), tais como: intervenções geopolíticas, ligadas à necessidade de defesa das fronteiras e ocupação do território; à gestão das atividades de extração mineral, sobretudo pela necessidade de estabelecer um controle efetivo das remessas de minerais para o exterior, especialmente o ouro, principalmente para Caiena, na Guiana Francesa, assim, a criação do Território Federal representava um passo para o estabelecimento de instrumentos de controle e fiscalização mais efetivos e de combate ao contrabando.

Outros elementos chaves também são destacados por Porto (2005) como chaves para a criação do Território Federal do Amapá: a influência de políticos locais, evidenciada na proposta da Comissão Nacional de Divisão Territorial que sugeriu, na década de 1930, a criação do Território Federal do Amapá, justamente sobre a área de influência política do Coronel José Júlio de Andrade e a criação do Território Federal do Acre, que serviu de inspiração para a criação de outros territórios, como o do Amapá, dentre outros.

Entretanto, no contexto de nossa análise, é importante destacar que, por força do Art. $2^{\circ}$ do Decreto-Lei 5.812 de 1943:

Passam para o Domínio da União os bens que, pertencendo aos Estados ou Municípios na forma da Constituição e das leis em vigor, se acham situados nos Territórios delimitados no artigo precedente. 
Esse repasse encontrou novo expediente com a publicação do Decreto-Lei 9.760 de 05 de Setembro de 1946, que confirmou as terras devolutas como bens da União. O próprio instrumento jurídico conceitua como devolutas as terras que, na faixa de fronteira, nos Territórios Federais e no Distrito Federal, não sendo próprias nem aplicadas a algum uso público federal, estadual ou municipal, não se incorporaram ao domínio privado. O próprio Decreto 9.760 estabelecia como características, para que fossem consideradas como terras particulares aquelas áreas que:

a) por fôrça da Lei $n^{\circ}$ 601, de 18 de setembro de 1850, Decreto $n^{\circ} 1.318$, de 30 de janeiro de 1854, e outras leis e decretos gerais, federais e estaduais; b) em virtude de alienação, concessão ou reconhecimento por parte da União ou dos Estados; c) em virtude de lei ou concessão emanada de govêrno estrangeiro e ratificada ou reconhecida, expressa ou implícitamente, pelo Brasil, em tratado ou convenção de limites; d) em virtude de sentença judicial com fôrça de coisa julgada; e) por se acharem em posse contínua e incontestada com justo título e boa fé, por têrmo superior a 20 (vinte) anos; f) por se acharem em posse pacífica e ininterrupta, por 30 (trinta) anos, independentemente de justo título e boa fé; g) por fôrça de sentença declaratória proferida nos têrmos do art. 148 da Constituição Federal, de 10 de Novembro de 1937. Parágrafo único. A posse a que a União condiciona a sua liberalidade não pode constituir latifúndio e depende do efetivo aproveitamento e morada do possuidor ou do seu preposto, integralmente satisfeitas por êstes, no caso de posse de terras situadas na faixa da fronteira, as condições especiais impostas na lei. (Grifo nosso)

Nos termos do Decreto-Lei 9.760, coube à SPU realizar os trabalhos de Discriminação Administrativa ou Judicial das Terras da União, a fim de descrevê-las, medi-las e extremá-las do domínio particular. Esse instrumento previa a regularização dos imóveis particulares, independentes se propriedades ou posses, cabendo os interessados:

(...) tirar na SPU, para seu título, instrumento de discriminação em forma de carta sentença, contendo o termo e ato solene (...). Tal carta, assinada pelo Diretor do SPU, terá força orgânica de instrumento público e conterá todos os requisitos necessários, para transcrições e averbações nos Registros Públicos.

Em seu Art. 164 a 170, o Decreto-Lei 9.760 estabelecia ainda, para a legitimação de posses em terras devolutas, os seguintes procedimentos: 
Proferida a sentença homologatória a que se refere o art. 57, iniciará a Fazenda Nacional a execução, sem embargo de qualquer recurso, requerendo preliminarmente ao Juíz da causa a intimação dos possuidores de áreas reconhecidas ou julgadas devolutas a legitimarem suas posses, caso o queiram, a lei o permita e o Govêrno Federal consinta-lhes fazê-lo, mediante pagamento das custas que porventura estiverem devendo e recolhimento aos cofres da União, dentro de 60 (sessenta) dias, da taxa de legitimação. Art. 169. Recolhidas aos cofres públicos nacionais as custas porventura devidas, as da avaliação e a taxa de legitimação, expedirá o Diretor do S.P.U., a quem subirá o respectivo processo, o título de legitimação, pelo qual pagará o legitimante apenas o sêlo devido. § 1ㅇ O titulo será confeccionado em forma de carta de sentença, com todos os característicos e individuações da propriedade a que se refere, segundo modêlo oficial. $\S 2^{\circ}$ Deverá ser registrado em livro a isso destinado pelo S.P.U., averbando-se ao lado, em coluna própria, a publicação no Diário Oficial da União, do Estado ou do Território, consoante seja o caso, ou na fôlha que lhe publicar o expediente, bem como a transcrição que do respectivo título se fizer no Registro Geral de Imóveis da Comarca de situação das terras, segundo o artigo subsequente. Art. 170. Será o título transcrito no competente Registro Geral de Imóveis, feita a necessária publicação no Diário Oficial da União, do Estado ou do Território, conforme o caso, ou na fôlha que lhe editar o expediente.

Nestes termos, abriu-se caminho administrativo-judicial para a regularização de propriedades e posses localizadas nas terras devolutas da União no Amapá. Esse instrumento abarcaria, portanto, a possiblidade de vários beneficiários obterem os títulos que trariam a segurança fundiária de suas ocupações.

Sob essa legislação, a Divisão de Terras e Colonização do TFA emitiu 1917 documentos de terras entre 1943 a 1973 nos cinco municípios então existentes, sendo 279 em Amapá, 1431 em Macapá, 187 em Mazagão, 15 em Oiapoque e 5 em Calçoene (NASCIMENTO, 2009, p.30)

Já sob o contexto do Estatuto da Terra (Lei 4.504 de 30 de novembro de 1964), Nascimento (2009, p. 30) destaca a criação do Instituto Brasileiro de Reforma Agrária (IBRA), em 1966, cuja ação de cadastramento de imóveis no Amapá chegou ao total de 1899 no ano de 1967. Nascimento (2009, p. 31) destaca ainda a edição do Decreto-Lei 1.164 de 1971, que:

(...) fixa como indispensáveis à segurança e ao desenvolvimento nacional as terras devolutas fixadas nas faixas de cem quilômetros 
das rodovias federais já construídas, em construção ou projetadas, incluindo-as como bens da União, perfazendo em torno de $60 \%$ da área total do Amapá. Já a lei n. 2597/1955, determinava uma largura de $150 \mathrm{~km}$, paralela à linha divisória da fronteira brasileira com países vizinhos. Por conseguinte, $90 \%$ das terras ficavam entre os bens da União e, portanto, sob a jurisdição do INCRA.

Tal como destaca Nascimento (2009), deve ser ressaltada a atuação do chamado Projeto Fundiário do Amapá, em 1973, órgão responsável pelas ações discriminatórias administrativas e judiciais das terras devolutas (Lei no 6.383 de 07 de dezembro de 1976), bem como ações de desapropriações e titulações diversas das terras do Amapá.

Para Jorge (2003, apud INCRA, 2004, p. 15), o INCRA agiu com eficiência, pois, no período de 23 anos, arrecadou e discriminou no Amapá 9.615.156 hectares $(67,02 \%$ da área do Estado), reconhecendo como terras de particulares uma área de 291.576 hectares $(2,03 \%)$, revelando o flagrante descaso com a regularização fundiária nos períodos anteriores sob a jurisdição do Estado do Pará. (NASCIMENTO, 2009, p. 31).

Contudo, esses registros não contam com informações suficientes para identificar quantos títulos foram expedidos em favor de famílias das comunidades afrodescendentes, uma vez que não havia previsão legal ou mesmo qualquer tipo de instrumento administrativo que orientasse esse tipo de procedimento. Porém, é sabido que algumas famílias oriundas das comunidades quilombolas possuíam documentos de suas terras, especialmente naquelas comunidades situadas no município de Macapá. Entretanto, não se tratavam de instrumentos de reconhecimento de direitos adequados às características culturais, identitárias e da territorialidade historicamente, compartilhada por aquelas famílias que, na falta de um instrumento de titulação coletiva de suas terras, se viam obrigadas a formalizar solicitações de regularização fundiária individual nas terras, que ocupavam coletivamente.

Com a promulgação da Constituição Federal de 1988, duas grandes alterações no contexto político-administrativo e social devem ser ressaltadas. A primeira trata da transformação do Território Federal do Amapá em Estado do 
Amapá. A segunda consiste na previsão constitucional do direito das comunidades tradicionais quilombolas a terem suas terras tituladas em instrumento específico, 0 que se deu por força do Art. 68 dos Atos das Disposições Constitucionais Transitórias (ADCT).

No que se refere à gestão das terras públicas federais no Amapá, Batista (2008) admite que

\begin{abstract}
A situação fundiária do Estado reflete uma grande disponibilidade de terras públicas federais, pois mais de $88 \%$ da superfície do Estado encontra-se sobre domínio da União Federal, sendo 42\% destas áreas destinadas à Unidades de Conservação, 8\% à Terras Indígenas, $7 \%$ a Projetos de Assentamento da Reforma Agrária e somente $6 \%$ está sobre o domínio de particulares (Batista et al., 2006), existindo, pelo menos, em torno de $25 \%$ da superfície estadual ainda em fase de destinação (regularização fundiária).
\end{abstract}

Estes números revelam a histórica incapacidade ou desinteresse do Estado Brasileiro em realizar as ações de destinação das terras públicas para a população amapaense, uma vez que estas terras públicas encontram-se há décadas ocupadas pelos mais diversos atores sociais e políticos, constituídos desde as comunidades tradicionais ribeirinhas, quilombolas, castanheiros, seringueiros etc., assim como posseiros oriundos das mais diversas regiões brasileiras. A omissão do Estado é, nesse contexto, uma das causas do cenário atual em que se encontram as demandas territoriais não apenas das comunidades quilombolas, mas também de outros grupos sociais subalternos.

\title{
5.2 - Titulação de terras quilombolas no Amapá: Histórico das ações e quadro atual
}

Assim como no restante do país, as demandas fundiárias que envolvem os direitos dessas comunidades do Amapá sofreram pela falta de regulamentação do dispositivo constitucional. Desta forma, a comunidade do Curiaú, com seus 3.268,9400, localizados no entorno da cidade Macapá, foi a primeira comunidade 
quilombola do Amapá a ter seu território reconhecido, em ato publicado no DOU de 18 de julho de 2000, ou seja, quase 12 anos após a promulgação Constitucional. Estes trabalhos ser deram por ação da FCP, com fundamento na Medida Provisória 1.911 de 19 de julho de 1999.

Silva, M. (2012) aponta que, até 2011, foram identificadas 138 comunidades quilombolas no Amapá. Contudo, deste montante, apenas 30 tinham a certidão de autorreconhecimento emitida pela FCP, sendo 17 processos de titulação de terras quilombolas em andamento, e duas comunidades, com títulos de domínio expedidos pelo INCRA: Comunidade Mel da Pedreira e Conceição do Macacoari, localizadas no município de Macapá.

Ao realizar um novo levantamento cujo recorte temporal se estende até o fim do exercício de 2016, notamos que os números da demanda evoluíram de maneira significativa, uma vez que a Superintendência Regional do INCRA encerrou esse exercício com 26 processos administrativos protocolados. Dos processos elencados por Silva (2012, p. 05), cabe informar que aquele referente à comunidade São Raimundo do Pirativa, localizado às margens do rio Matapí, no município de Santana, fora contemplado pela SPU, via emissão de Portaria de Declaração de Interesse do Serviço Público (PDISP), uma vez que as terras, reivindicadas pela comunidade, situam integralmente em áreas de marinha, sendo jurisdição daquela autarquia ligada ao Ministério do Planejamento, Orçamento e Gestão. A Figura 07 demonstra a localização dos territórios delimitados até o momento da finalização deste estudo, ou seja, aqueles que se encontram com RTID publicado ou título definitivo emitido pelo INCRA, SPU ou FCP: 


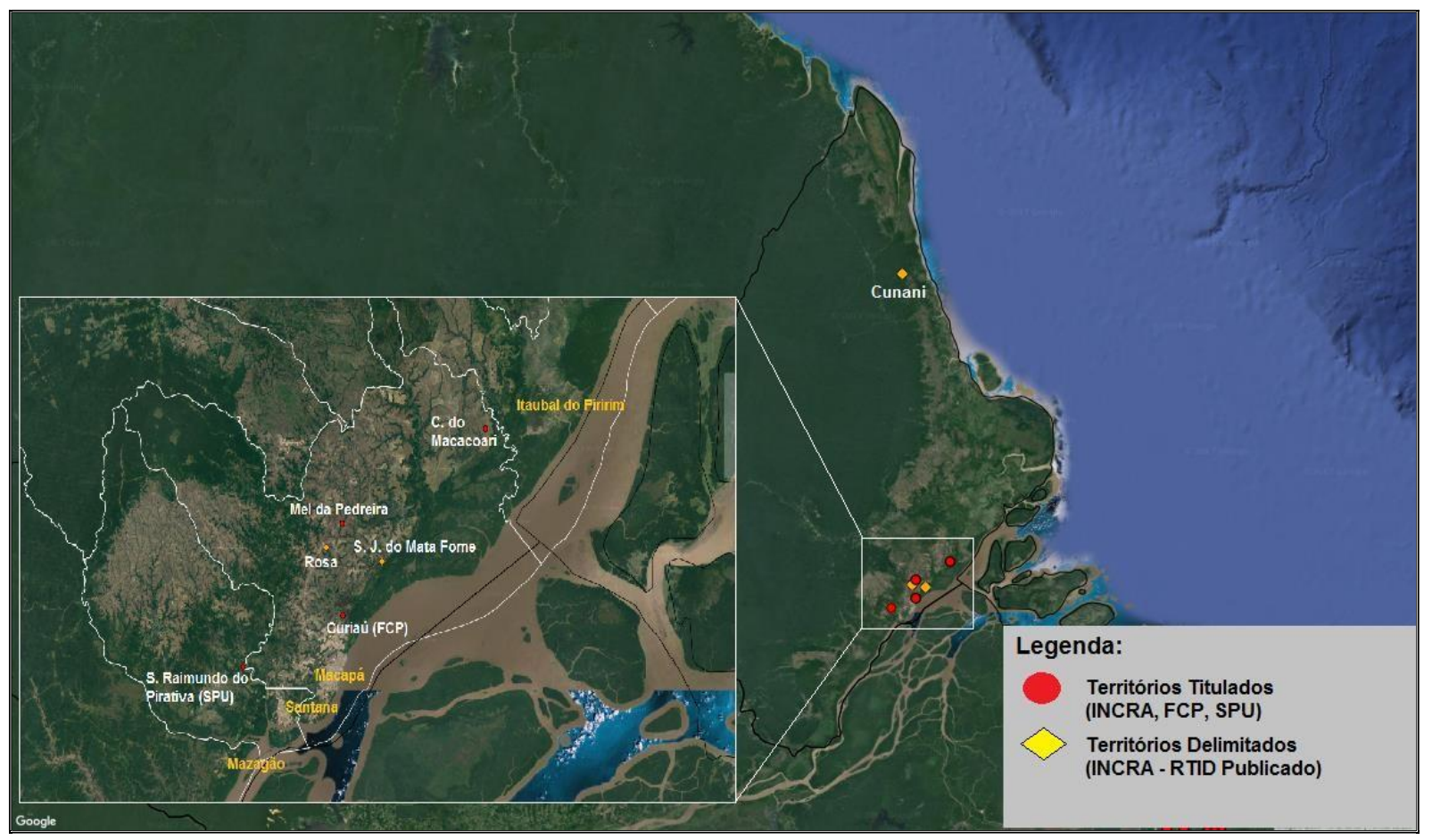

Figura 07: Localização das comunidades quilombolas com territórios delimitados no Amapá: RTID Publicados e Títulos Expedidos (2016). Fonte: Acervo Fundiário (INCRA); GoogleMaps. Elaborado pelo autor.

O Quadro 07 detalha a situação de cada um dos processos, que se encontram em andamento na Superintendência Regional do INCRA no Amapá, organizados por data de abertura do processo administrativo: 


\begin{tabular}{|c|c|c|c|c|}
\hline \begin{tabular}{|c|}
$№$ DE \\
ORDEM
\end{tabular} & Ano & Comunidade & Município & Fase Processual \\
\hline 01 & 2004 & Cunani & Calçoene & RTID publicado \\
\hline 02 & 2004 & Lagoa dos Índios & Macapá & $\begin{array}{c}\text { Relatório } \\
\text { antropológico em } \\
\text { andamento }\end{array}$ \\
\hline 03 & 2004 & Rosa & Macapá & Portaria Publicada \\
\hline 04 & 2005 & Ambé & Macapá & Estudo Fundiário \\
\hline 05 & 2005 & Ilha Redonda & Macapá & $\begin{array}{c}\text { Relatório } \\
\text { Antropológico em } \\
\text { andamento }\end{array}$ \\
\hline 06 & 2005 & São José do Mata Fome & Macapá & $1^{\circ}$ instância \\
\hline 07 & 2006 & São Pedro dos Bois & Macapá & Estudo Fundiário \\
\hline 08 & 2008 & Cinco Chagas do Matapi & Santana & $\begin{array}{c}\text { Relatório } \\
\text { Antropológico em } \\
\text { andamento }\end{array}$ \\
\hline 09 & 2008 & São Tomé do Aporema & Tartarugalzinho & RTID concluído \\
\hline 10 & 2010 & Engenho do Matapi & Santana & Estudo Fundiário \\
\hline 11 & 2010 & Kulumbu do Patualzinho & Oiapoque & $\begin{array}{c}\text { Nenhuma peça } \\
\text { técnica em } \\
\text { elaboração }\end{array}$ \\
\hline 12 & 2011 & Igarapé do Palha & Fer. Gomes & $\begin{array}{c}\text { Relatório } \\
\text { Antropológico em } \\
\text { andamento }\end{array}$ \\
\hline 13 & 2011 & Ressaca da Pedreira & Macapá & $\begin{array}{c}\text { Relatório } \\
\text { Antropológico em } \\
\text { andamento }\end{array}$ \\
\hline 14 & 2012 & Curralinho & Macapá & $\begin{array}{c}\text { Relatório } \\
\text { Antropológico em } \\
\text { andamento }\end{array}$ \\
\hline 15 & 2012 & $\begin{array}{c}\text { №. Sra } \text {. do Dest. Dos Dois } \\
\text { Irmãos }\end{array}$ & Santana & $\begin{array}{c}\text { Relatório } \\
\text { Antropológico em } \\
\text { andamento }\end{array}$ \\
\hline
\end{tabular}




\begin{tabular}{|c|c|c|c|c|}
\hline 16 & 2012 & St”‥ Luzia do Maruanum & Macapá & $\begin{array}{c}\text { Relatório } \\
\text { Antropológico em } \\
\text { andamento }\end{array}$ \\
\hline 17 & 2012 & São Miguel do Macacoari & Itaubal & $\begin{array}{c}\text { Relatório } \\
\text { Antropológico em } \\
\text { andamento }\end{array}$ \\
\hline 18 & 2013 & Campina Grande & Macapá & $\begin{array}{c}\text { Relatório } \\
\text { Antropológico em } \\
\text { andamento }\end{array}$ \\
\hline 19 & 2013 & Carmo do Maruanum I & Macapá & $\begin{array}{l}\text { Nenhuma peça } \\
\text { técnica em } \\
\text { elaboração }\end{array}$ \\
\hline 20 & 2013 & Igarapé do Lago & Santana & $\begin{array}{c}\text { Nenhuma peça } \\
\text { técnica em } \\
\text { elaboração }\end{array}$ \\
\hline 21 & 2013 & $\begin{array}{l}\text { São José do Matapi do Porto } \\
\text { do Céu }\end{array}$ & Macapá & $\begin{array}{c}\text { Relatório } \\
\text { Antropológico em } \\
\text { andamento }\end{array}$ \\
\hline 22 & 2013 & São João I do Maruanum II & Macapá & $\begin{array}{c}\text { Relatório } \\
\text { Antropológico em } \\
\text { andamento }\end{array}$ \\
\hline 23 & 2013 & Tapera & Laranjal do Jari & $\begin{array}{c}\text { Nenhuma peça } \\
\text { técnica em } \\
\text { elaboração }\end{array}$ \\
\hline 24 & 2014 & Alto Pirativa & Santana & $\begin{array}{c}\text { Relatório } \\
\text { Antropológico em } \\
\text { andamento }\end{array}$ \\
\hline 25 & 2014 & Lagoa do Maracá & Mazagão & $\begin{array}{c}\text { Relatório } \\
\text { Antropológico em } \\
\text { andamento }\end{array}$ \\
\hline 26 & 2014 & Santo Antônio do Matapi & Santana & $\begin{array}{c}\text { Relatório } \\
\text { Antropológico em } \\
\text { andamento }\end{array}$ \\
\hline
\end{tabular}

Quadro 07: INCRA - Titulação das terras quilombolas no Amapá: situação dos processos administrativos, 2016. Fonte: INCRA/SR21/F4 (relatório interno). Adaptado pelo autor. 
De acordo com os dados contidos no Quadro 07, observa-se que 07 dos 26 procedimentos, que ainda não foram finalizados, referem-se ao PPA 2004-07. Destes, o que se encontra num estágio processual mais avançado é a demanda da Comunidade do Rosa, cuja portaria de reconhecimento foi publicada no DOU de 22 de dezembro de 2016, referentes a uma área de 4.984 ha, localizados na zona rural do município de Macapá. Em seguida, o processo referente à comunidade de Cunani, cujo RTID foi publicado no DOU em 04 de novembro de 2016.

Não obstante, são 06 os processos iniciados no PPA 2008-11 que ainda não foram finalizados, sendo que destes, apenas o referente à comunidade de São Tomé do Aporema teve seu RTID publicado. A demanda da comunidade Engenho do Matapí também obteve algum tipo de avanço, pois o seu relatório antropológico foi finalizado, e falta a conclusão das demais peças que compõem o RTID, para que se possa realizar a publicação.

De acordo com os dados contidos no Quadro 07, é evidente que a dificuldade na elaboração dos Relatórios Antropológicos (RA's) é um dos gargalos para a instrução dos processos administrativos, o que é admitido pelo Chefe do Serviço de Regularização de Territórios Quilombolas da Superintendência do INCRA no Amapá, Mateus Pagliarini. Segundo o gestor, há apenas um servidor, com habilitação em Antropologia, no quadro da Superintendência Regional e o mesmo não se encontra lotado no setor, para o qual foi contratado. Assim, as demandas referentes à elaboração desses relatórios têm sido repassadas a servidores "emprestados" por outras superintendências do INCRA e da Sede, em Brasília. Essa alternativa está sendo utilizada para a elaboração dos RA's das comunidades de Ilha Redonda, Lagoa dos Índios, São José do Matapi e Ressaca da Pedreira. Outro expediente adotado é a contratação de empresas, via pregão eletrônico, para elaboração desses estudos, o que envolve atualmente as comunidades de Campina Grande, Alto Pirativa, Santo Antônio do Matapi, № ${ }^{a} r^{a}$ do Desterro dos Dois Irmãos, Igarapé do Palha, Curralinho, São João I do Maruanum II, Santa Luzia do Maruanum I, São Miguel do Macacoari e Lagoa do Maracá, totalizando, portanto, 10 comunidades atendidas. Todavia, para o gestor do Serviço Quilombola do INCRA/AP, existem outros gargalos além da "falta de estrutura" que resultam na ineficiência flagrante da autarquia em promover a titulação das terras quilombolas no Amapá: 
A demora para que o INCRA consiga fazer a regularização de um território é exagerada, pela falta de estrutura e pela complexidade da norma, que acaba pedindo mais do que o próprio Decreto. Sempre que esse ponto é abordado junto à diretoria do INCRA eles alegam que essa IN foi feita em conjunto com diversos órgãos e com representantes dos quilombolas, e para refazer deveria haver uma nova união de todos atores para fazer uma nova IN. O que dificulta o trabalho é $50 \%$ a IN e $50 \%$ dificuldade da própria autarquia em dar continuidade aos procedimentos - infraestrutura-. (Mateus Pagliarini, INCRA/AP. Informação verbal).

O diagnóstico de Padre Sisto, representante da CPT/AP é parecido com do gestor do INCRA/AP, mas salienta ainda que

O processo (titulação de terras quilombolas) é lento por si próprio e não teria como ser rápido por uma série de questões. Além disso, a própria política de estado não é favorável às comunidades quilombolas. Hoje o Brasil tá mais voltado a reconhecer o agronegócio como um sistema de desenvolvimento para o país do que as comunidades quilombolas. (...) Para chegar à titulação de uma área de quilombolas tem que ter verba. Não vi no passado verba suficiente para a titulação de todas as áreas. A segunda é a falta de interesse do governo em alavancar o interesse das áreas quilombolas por causa do agronegócio. (Padre Sisto, CPT/AP. Informação verbal)

Numa constatação, compartilhada por Silva, M. (2012), Padre Sisto identifica ainda outro fator, que coopera para a dificuldade de se dar prosseguimento a esses pleitos, que é a falta de coesão interna das próprias comunidades, frente ao pleito de titulação de suas terras:

(...) pois os velhos querem a titulação. Os filhos, que moram na cidade de Macapá, são bem sucedidos e tem outros meios para sobreviver, não querem, pois eles veem as terras como mercadoria para futura venda para empresários do agronegócio. Os pais puxam pra um lado e os filhos para outro. Há um conflito geracional. E a burocracia também é bem forte, mas eu acho que tem que ter burocracia mesmo para que seja bem feito. (Padre Sisto, CPT/AP. 
Informação verbal)

A constatação do representante da CPT/AP é compartilhada pela Presidente da CONAQ/AP, ao afirmar que esse mesmo fenômeno é identificado, no seio do próprio movimento negro no Amapá, onde os "urbanos ou povo da cidade" - são em grande parte oriundos das comunidades rurais e não compactuam com a política quilombola nos termos atuais. Essa cisão, no âmbito do movimento, fica ainda mais evidente, quando a Sra. Hidma relembra os primeiros passos do movimento negro no âmbito das ações quilombolas no Amapá:

(...) montamos um fórum de discussão antes de fazer a CONAQ/AP mas já tínhamos contato com a CONAQ. Fizemos o fórum das comunidades quilombolas rurais e urbanas, que se reunia na União dos Negros do Amapá - UNA e, fui convidada para um encontro no Maranhão e fui tomar conhecimento. Dividíamos nos polos de Macapá Urbano, Rodovia AP-70, do KM-21, do Santo Antônio-RosaAmbé, Calçoene-Oiapoque, mas funcionava mesmo era o AP-70 e Macapá Urbano. Quem se identificava já tocava o polos. Até que ficamos sem espaço para reunir. Depois um amigo ofereceu uma sala na Agência de Desenvolvimento do Amapá - ADAP para reunir. Ai o embate foi muito grande porque o pessoal começou a colocar diabinho e chegamos a conclusão que não dava para trabalhar junto quilombolas urbanos e rurais, porque os quilombolas rurais ficavam à mercê dos quilombolas urbanos, que não aceitavam a causa quilombola e resolvemos nos separar. Então esse fórum esfacelou e contribuiu para a primeira eleição do Waldez, pois uma parte era do PDT. Vinha o pessoal da Ilha Redonda, um lado queria o outro lado não queria.

(...) cada um tem seu partido, mas na época da eleição o movimento se esfacela... Não dá para eleger só um pra ser candidato, na verdade cada um quer ser candidato... Eu já fui candidata, a Núbia já foi candidata, mas fomos bombardeados pelo povo da cidade. Os urbanos fazem a maior confusão, ELES QUEREM DESTRUIR... (Hildma, CONAQ/AP. Informação verbal).

A falta de coesão, no seio do próprio movimento negro em relação às ações de titulação das terras quilombolas, tem relação direta com a partidarização do movimento e com os conflitos geracionais, que podem ser representados pelos quilombolas urbanos (gerações mais novas, que tendem a não concordar com a titulação das terras devido às cláusulas restritivas impostas, pois as reconhecem como mercadoria que futuramente pode ser negociada no mercado imobiliário) e quilombolas rurais (especialmente os mais velhos, que tendem a concordar com a 
titulação das terras quilombolas, como alternativa para preservação da sua identidade territorial). Esse cenário reflete diretamente na baixa capacidade de mobilização das lideranças quilombolas frente ao INCRA/AP.

Foi possível identificar que a dificuldade de mobilização dos movimentos em defesa das demandas quilombolas junto aos órgãos competentes, como o INCRA, é desempenhado basicamente pela atuação do Ministério Público Federal.

Deus nos livre se não tivesse o MPF e PF, por que mesmo tendo os quilombolas são assassinados. Imagina se não tivesse! (Hildma, CONAQ/AP. Informação verbal)

A fala da representante da CONAQ/AP reforça um ponto que nos parece inquestionável no sentimento compartilhado pelas lideranças quilombolas e pelos demais atores ouvidos, que é a atuação do MPF. Este órgão é encarado pelos envolvidos na questão quilombola como sendo o mais importante ator de pressão, junto ao poder público em geral e, sobretudo, ao INCRA, tal qual admite o gestor do serviço quilombola Mateus Pagliarini, do INCRA/AP:

Às vezes nos sentimos incomodados com alguns questionamentos do MPF, mas isso faz com que o INCRA volte os olhos para as comunidades e que consiga recursos. Então, a gente vê como positiva, pois nós temos como pressionar a Direção do INCRA para trabalhar nos processos. (Mateus Pagliarini, INCRA/AP. Informação verbal).

Padre Sisto, em sua avaliação sobre atuação do MPF na questão quilombola no Amapá, salienta que, apesar de desempenharem um papel importante, a rotatividade dos procuradores no estado faz com que os direitos das comunidades sejam prejudicados:

Nós tínhamos um bom grupo de promotores e procuradores, como o 
Thiago que atuou no Cunani e entrou na Justiça contra o invasor no Cunani. Mas eles passam menos de dois anos por aqui e quando começam a se interar dos processos e conflitos eles vão embora. (Padre Sisto, CPT/AP. Informação verbal)

\section{3 - Conflitos Fundiários e institucionais na titulação das terras quilombolas no Amapá}

Conforme discutido nos capítulos anteriores, é evidente a ineficiência do Estado Brasileiro em garantir os direitos à titulação das terras das comunidades tradicionais quilombolas. Sobre esse tema, Fiabani (2013, p.58) afirma que

Os principais entraves à titulação das comunidades são: a burocracia estatal, política agrária ineficaz do governo federal e a oposição ao movimento, exercida pelos representantes do agronegócio, fazendeiros, latifundiários, madeireiros, mineradoras e outros.

Essa situação, identificada por Fiabani (2013), é terreno fértil para o surgimento de vários impasses, tensões e até mesmo conflitos, que envolvam as comunidades quilombolas, confrontando-as com os interesses dos mais diversos segmentos da sociedade, especialmente do setor denominado agronegócio que, segundo Almeida (2010, p. 318), faz gerar pressões sobre as terras tradicionais. O pesquisador identifica, nesse contexto, três constatações que explicam esse fenômeno:

A primeira constatação decorrente é que a elevação geral dos preços das commodities agrícolas e minerais, propiciando um ritmo forte de crescimento dos agronegócios, tem resultado num aumento da demanda por terras. Tal demanda ocorre tanto para fins de extração de minério de ferro, bauxita, caulim e ouro, quanto para a implementação de grandes plantações homogêneas com fins industriais (eucalipto, pinus, cana-de-açúcar, soja, algodão, mamona, dendê) e para agropecuárias com expansão de pastagens artificiais, que implicam em desmatamentos, ou ainda para usinas de ferrogusa e carvoarias. Uma outra constatação diz respeito à intensificação das chamadas "obras de infraestrutura" ou grandes projetos governamentais, tais como: rodovias, hidrovias, barragens, portos e aeroportos; bem como iniciativas ligadas à política de segurança, como no caso das bases militares, ou à política ambiental, como no caso de implantação de unidades de 
conservação ambiental de proteção integral. A terceira constatação é mais específica, e refere-se ao direcionamento de interesses empresariais para terras que estão com sua cobertura vegetal relativamente preservada, compondo estoques de carbono, e ao mesmo tempo encontram-se sobre o controle de comunidades, cujos princípios de gestão dos recursos naturais privilegiam a preservação e não permitem que sejam dispostas a transações mercantis. Os artifícios utilizados pelas estratégias empresariais implicam em tentativas de incorporar tais extensões ao mercado de terras e, em decorrência, às bolsas de valores que negociam créditos de carbono. Isto concorre para explicar o elevado percentual de terras tradicionalmente ocupadas diretamente referidas a situações de tensão social e conflito que, como já foi dito, perfazem pouco menos de um terço do total geral de ocorrências registradas em 2009. (in: Projeto Nova Cartografia Social da Amazônia, 2010) - Grifo nosso.

Reforço a posição anteriormente adotada de que, dada a complexidade das tensões e conflitos evidenciados pela titulação de suas terras, é latente a necessidade de delimitação do objeto de nossa análise a um território específico. Devido à representatividade e particularidades, identificadas na Amazônia e do Amapá, optamos por aprofundar nossa análise ao contexto desse estado da região Norte do Brasil. Ademais, a representatividade da região Norte e do Amapá para a discussão das ações de titulação das terras quilombolas são somadas à experiência profissional deste pesquisador, enquanto servidor do INCRA nesse estado, entre os anos de 2006 a 2013, período em que acumulou práticas e vivências cotidianas com os atores envolvidos e participou ativamente no processo político-institucional.

\section{Titulação das terras quilombolas: gestão de conflitos e interesses}

No contexto da abordagem das relações de poder no campo brasileiro, a proposta conceitual apresentada por pela Comissão Pastoral da Terra (CPT) (2015, p. 13), define por conflito "as ações de resistência e enfrentamento que acontecem em diferentes contextos sociais no âmbito rural, envolvendo a luta pela terra, água, direitos e pelos meios de trabalho e produção". Nesse mesmo contexto, Tavares (2009) aponta que

(...) os conflitos pela posse e propriedade da terra, presentes em todas as regiões brasileiras, são marcados por inúmeros atos violentos, o que significa uma ação generalizada contra formas de luta pela terra das populações rurais brasileiras. 
No que se refere à origem dos conflitos pela terra, CPT (2015) aponta a ausência ou má gestão das políticas públicas como um dos fatores de maior relevância. Nessa perspectiva, as políticas de acesso à terra, no Brasil, sempre foram objeto de várias controvérsias ideológicas, políticas e conceituais. A própria viabilidade social da reforma agrária é uma questão que permeia os debates políticos e acadêmicos (Fernandes, 2008; Tavares, 2009). Porém, à medida que a histórica celeuma, inerente à questão agrária não é superada, outras questões tomam corpo e assumem novas relevâncias na sociedade brasileira, tais como a questão ambiental, dos direitos humanos, da igualdade racial etc. Ao analisar os conflitos no campo brasileiro, no ano de 2011, Canuto (2012) indica que

(...) o período foi marcado por fatos que vão compor a história social do nosso país. (...) Começou com a morte do casal de defensores da Floresta, no sul do Pará, Maria do Espírito Santo e José Cláudio Ribeiro da Silva (...), atingiu outros trabalhadores na mesma região, se estendeu para Rondônia e o Amazonas, chegou ao Tocantins, propagou-se por áreas quilombolas do Maranhão e do Norte de Minas e ricocheteou sobre agentes da CPT no Acre e no Mato Grosso".

A região amazônica também é um objeto de extrema relevância para essa investigação de Canuto (2012) onde o autor aponta que 69\% do total de conflitos por terra, 79,3\% dos assassinatos, $85 \%$ das ameaças de morte ocorrem na região amazônica. Atividades ligadas à mineração, exploração madeireira e terras para agropecuária convergem para a efetivação de uma lógica que reproduz um modelo colonizador, pautado na predação dos recursos naturais, espoliação das comunidades existentes, concentração da propriedade da terra e violência.

No que se refere aos grupos sociais envolvidos nessa questão, Canuto (2012) aponta que $72 \%$ das pessoas estão sendo ameaçadas de morte por questões ligadas aos territórios quilombolas, indígenas ou de outras comunidades tradicionais. Assim, corroborando a afirmação de Canuto, compreendemos que as ações de titulação das terras quilombolas se fundamentam como um objeto de intensa relevância para a análise dos conflitos fundiários no Brasil, haja vista a abundância de questões que envolvam não apenas os conflitos pelo acesso à terra em si, mas devido ao fato de seu produto ser a base para a eficiência de outras 
políticas públicas, que cooperam para a melhoria da qualidade de vida dessas populações e à gestão ambiental do território. Vale ressaltar, também, que tais comunidades são amplamente reconhecidas como grupos sociais, que adotam práticas de exploração dos recursos naturais, de forma mais sustentável em relação àquelas empreendidas pela grande exploração econômica (Guarim, 2000; Castro, 1998).

Na perspectiva das ações de titulação das terras quilombolas, nos parece basilar a proposição de um conceito que abarque a compreensão de que esses eventos fazem parte de um longo processo histórico, que vem tomando formas e significados bastante particulares no contexto das ações de garantia da segurança fundiária às comunidades quilombolas. Sua compreensão, no âmbito da Amazônia brasileira e no Amapá, está ligada especialmente à:

- Tardia previsão constitucional e regulamentação por lei específica dos direitos de titulação das terras quilombolas;

- Histórica ineficiência do poder público em promover a destinação/regularização fundiária das terras públicas federais, o que impossibilitou a adequada regularização fundiária das terras das famílias, que compõem as comunidades tradicionais, localizadas nas glebas federais, seja de forma individual ou coletiva, antes da Constituição Federal de 1988;

- Ascensão de grupos de pressão política e social no cenário nacional como a CONAQ, que passaram a representar o contraponto das comunidades tradicionais negras no cenário político e social que, outrora, negligenciava ou se omitia frente a suas demandas;

- Concorrência enfrentada pelos quilombolas com outros grupos sociais ou de pressão (assentados da reforma agrária, ambientalistas, ruralistas etc.) capazes de competir pela agenda governamental (quem governa) e de influir efetivamente na vontade política dos gestores públicos;

- Disputas entre os próprios órgãos públicos pelo atendimento das prerrogativas das políticas que executa, principalmente, quando há sobreposição de interesses institucionais (controvérsias). 
O conflito, nessa perspectiva, torna-se mais evidente nos confrontos físicos e imposições da vontade de determinado ator sobre o outro, a partir do uso da força, como na resistência pela manutenção da ocupação, posse e/ou domínio de suas terras tradicionais, na proibição de acesso das comunidades aos recursos materiais e bens imateriais, às barreiras à livre circulação das populações quilombolas etc. Entretanto, esses episódios não devem ser encarados como eventos isolados ou descolados de uma análise histórica e regional, pois constituem-se como produto de um processo mais amplo, que o determina. O conflito é compreendido como o resultado da disputa entre demandas fundiárias que, dada a omissão ou ineficiência do Estado, originaram controvérsias institucionais, que opõem interesses de órgãos do poder público, bem como outros impasses, litígios, tensões, ameaças ou ações violentas, que abarcam os demais atores sociais envolvidos, capazes de representar um cenário de insegurança fundiária ou jurídica às populações tradicionais.

Entende-se que os conflitos devam ser analisados, sem desconsiderar 0 papel, que os grupos sociais e de pressão desempenham na busca pela influência, determinação ou controle sobre a agenda pública e a vontade política dos governos. Nesse sentido, alguns pontos balizadores devem ser considerados:

- O papel do poder público, enquanto agente regulador, mediador e provedor de conflitos;

- A dimensão territorial, que se atém às características da apropriação funcional, mas também simbólica do território;

- A dimensão temporal, que se pauta na consideração dos diferentes modelos históricos, evidenciados na apropriação do espaço geográfico e das territorialidades daí resultantes.

É imprescindível, portanto, que se considere a interdependência dos elementos ligados às demandas históricas pelos recursos sociais, produtivos e bens imateriais, bem como a forma com que essa mesma sociedade se organiza e se hierarquiza em torno da distribuição, do acesso e manutenção desses bens. As políticas oficiais, aquelas ligadas ao poder público legalmente constituído, assumem relevância fundamental na perspectiva da necessidade de gestão e resolução 
desses conflitos, assim como do compromisso que assumem pela melhoria da qualidade de vida dessas populações e a garantia de sustentabilidade no uso dos recursos naturais envolvidos, via garantida da segurança fundiária.

Por se tratar de uma ação de intervenção direta no quadro fundiário da região onde é executada, a titulação das terras quilombolas acarreta diversos impactos nas sociedades e economias locais, pois abre perspectiva para a desapropriação de imóveis ligados, não apenas a setores bem organizados, consolidados e influentes, no cenário político regional, nacional e até internacional, como grandes as grandes corporações do agronegócio, minerário e imobiliário, bem como de grupos ambientalistas, para Mello (2003, p.341), se apresentam como novos atores que atuam na definição de políticas públicas

(...) não somente reivindicando mas, especialmente, definindo novos modelos por meio de experiências locais. Lançam ideias que recolocam localmente as preocupações mundiais sobre o meio ambiente, o desenvolvimento sustentável, proteção de biodiversidade, das florestas, do patrimônio natural, etc. Estes novos discursos ocupam os meios de comunicação em escala nacional e têm importante apelo no seio das políticas públicas.

Além desses novos e velhos atores, identificamos também aqueles pertencentes a grupos sociais caracterizados pela baixa capacidade de organização social e que possuem menor renda (e consequentemente menos capacidade de resistência), como é o caso dos pequenos agricultores não-quilombolas, populações ribeirinhas, vazanteiras, pescadores e artesãos que porventura estejam ocupando as terras reivindicadas pelas comunidades afrodescendentes.

Há que se ressaltar também a sobreposição de interesses de atores que se postam no seio do próprio Estado, pois são várias as situações em que a área tradicional pleiteada foi destinada pelo poder público para a constituição de unidades de conservação ou com outros interesses sociais ou estratégicos, como áreas militares, terras públicas destinadas a projetos habitacionais, aterros sanitários etc., ocasionando complexas situações de sobreposição de interesses institucionais contraditórios e, por consequência, de perspectivas distintas da apreensão do interesse público. 
Muitos conflitos fundiários existentes estão atrelados à relação sociedade-território e, consequentemente, problemas sociais foram criados e acentuados no Brasil, em decorrência da formação territorial, na qual predominou a ideia de modernização sem a inclusão social, na qual se insere também uma visão de proteção da natureza, implicada, muitas vezes, no condicionamento do modo de vida de populações nas áreas onde foram implantadas as Unidades de Conservação. No presente, são sobreviventes dos conflitos fundiários existentes na região, grande parte das suas terras ainda estão nas mãos dos latifundiários (posseiros grileiros), além da criação das Unidades de Conservação que abrangem seu território. (GIACOMINI, 2009, p. 06)

Esse cenário expõe o pleito das comunidades quilombolas ao enfrentamento de resistências diversas que acabam, na grande maioria dos casos, representando um longo dispêndio de tempo e recursos públicos para a realização de pesquisas, diagnósticos e peças técnicas que, ao cabo de vários anos ou décadas, não resultaram em titulações das terras quilombolas, conforme observado no capítulo anterior.

Para além desses impasses políticos, sociais e institucionais, é extremamente relevante a consideração da complexidade burocrático-administrativa que a legislação quilombola adquiriu com o passar dos anos, especialmente na década de 2000, o que coopera, em conjunto com outros fatores, para a inevitável judicialização das demandas quilombolas.

Esse fenômeno faz com que o Governo opte, sorrateiramente, por priorizar os processos administrativos quilombolas, em que os impactos políticos, institucionais e sociais são menos significativos, sob sua própria ótica. Nesse cenário, as demandas que envolvem altos custos políticos e sociais, impasses institucionais ou que necessitam de elevadas somas de recursos orçamentários para desapropriação/indenização são negligenciados, sem nenhuma expectativa concreta de titulação das terras.

Essa situação acarreta um cenário de instabilidade fundiária, social, econômica e produtiva não apenas para as comunidades quilombolas, que continuarão sem acesso aos recursos produtivos, que necessitam para sua reprodução, e sem o documento que lhes confere a segurança fundiária das áreas que ocupam, mas também para os demais atores envolvidos, haja vista que a indefinição sobre o atendimento das demandas quilombolas afasta os investimentos privados nas áreas reivindicadas e no seu entorno, além de impactar, 
negativamente, o preço das terras da região e acirrar os ânimos dos grupos sociais e políticos, eventualmente, contrários à titulação dessas terras em favor das comunidades tradicionais.

A gestão desses impactos sócio-políticos e dos conflitos, evidenciados pelos processos das terras quilombolas é um dos componentes metodológicos definidos na matriz de análise proposta no Capítulo 01. Propomos, nesse momento, delimitar nossa abordagem à identificação e análise do papel que hoje é desenvolvido pelo Estado e Governo (na perspectiva mais ampla de "quem governa" e "com quem se governa"), bem como das ferramentas que são empregadas nas instâncias administrativas para a gestão/resolução das tensões e conflitos fundiários, institucionais e dos impactos sociopolíticos eventualmente trazidos à tona, quando da abertura do processo de titulação das terras quilombolas.

Dados identificados, sistematizados e disponibilizados por CPT (2015) revelam que os conflitos, envolvendo as comunidades quilombolas estão presentes em todo o Amapá, abrangendo, somente nos anos 2014 e 2015, pelo menos 180 famílias quilombolas, motivados não apenas por litígios que implicam fazendeiros/posseiros, mas também por instituições do poder público federal e estadual, em desfavor do interesse das comunidades tradicionais. Para um melhor reconhecimento da dimensão e natureza dos conflitos que abarcam as populações quilombolas no Amapá, resolvemos construir nossa abordagem, a partir da análise da atuação das instituições mais representativas no cenário político-social do Amapá, na condução dos processos que envolvem a titulação das terras quilombolas nesse estado. Serão construídas a partir dos documentos que atestam as várias ações e manifestações dos seguintes atores:

- INCRA, a partir da análise dos processos administrativos de regularização das terras quilombolas;

- Relatórios da Comissão Pastoral da Terra (CPT/AP);

Documentos disponibilizados pela CONAQ/AP, bem como entrevistas com representantes daquele estado;

- Documentos expedidos pelo Ministério Público Federal (MPF/AP), no âmbito da 6ª Câmara de Coordenação e Revisão. 
A questão, que abrange a comunidade quilombola de Conceição do Macacoari (Processo INCRA 54350.000393/2005-23), motivou a expedição pelo MPF/AP da Recomendação no 06/2015/MPF/AP que, por sua vez, é parte integrante do Inquérito Civil no 1.12.000.000833/2013-27. Trata-se de um conflito, a partir da abertura de uma estrada, inclusive com licença ambiental, expedida pelo órgão estadual competente, cujo traçado cortaria o interior do território quilombola, sem o consentimento da comunidade. Relatos do Padre Sisto Magro, integrante da CPT/AP, versa ainda sobre

(...) uma ação na justiça entre a associação do quilombo e uma pessoa que estava passando pelo quilombo para poder chegar à área dele. Também seria uma pessoa ligada ao agronegócio que futuramente poderia usar da passagem para o próprio empreendimento. A ação movida pelo empresário estava na justiça estadual e em seguida quando transferida para a justiça federal parou. (Padre Sisto, CPT/AP. Informação verbal)

Mas, após a manifestação dos envolvidos e apuração dos fatos por parte do INCRA, apurou-se que tudo foi motivado por uma falha no memorial descritivo do território, elaborado pela INCRA, quando da sua titulação. A Sra. Hildma, Presidente da CONAQ/AP informa que é intenção da presidente da Associação, que representa a comunidade, é a de processar o INCRA pela falha na demarcação dos limites da propriedade.

O título de domínio coletivo foi emitido em favor da comunidade em 02 de janeiro de 2006, contemplando 20 famílias quilombolas num território demarcado de $8.475,4710$ ha.

Outra comunidade quilombola comprometida com conflitos fundiários é a Comunidade Igarapé do Palha - (Processo INCRA 54350.000153/2011-77). No dia 12 de agosto de 2013, o Ministério Público Federal (MPF), através da Procuradoria da República no Estado do Amapá (MPF/AP), instaurou o Inquérito Civil Público no 1.12.000.000583/2013-25, que trata do "atraso injustificável no processo de regularização fundiária da área tradicionalmente ocupada pela comunidade remanescente de quilombo denominada Igarapé do Palha, situada no município de Ferreira Gomes/AP". Nos autos desse inquérito, foi expedida a Recomendação № 21/2013/MPF/AP. Dentre as considerações, destacamos aquelas que versam sobre 
o conflito evidenciado, que falam sobre

(...) o grave relato de membros da comunidade de que fazendeiros locais, em ação de expropriação da terra, invadiram terras da comunidade e bloquearam o acesso terrestre à vila, ocasionando o êxodo rural, subsistindo, tão somente, 3 (três) famílias de um grupo originário bem maior (...); que o processo de expropriação da terra impossibilitou aos membros da comunidade a manutenção de seu modo de vida e subsistência, compelindo-os à periferia do Município de Ferreira Gomes/AP; (...) que até mesmo as tradições culturais (festas de santo), que remontam há mais de 100 anos, não são mais realizadas no seio da comunidade ante os atos expostos.

Segue ainda a Recomendação № 21/2013/MPF/AP afirmando que, a resposta dada pelo INCRA, através do Ofício № 692/2013 - GAB/INCRA/AP, foi o argumento de que os trabalhos não haviam ainda sido iniciados por escassez de equipe técnica. Segundo a representante da CONAQ/AP, "no Palha, já morreu muita gente. O pessoal se evade pra Ferreira com medo de morrer".

Diante desse cenário, a Recomendação estabelece que a Superintendência Regional do INCRA no Amapá - INCRA/SR21/AP:

(...) adote providências cabíveis para o reconhecimento da Comunidade (...). (...) que, em caso de ausência ou insuficiência de pessoal, celebre convênios, contrate servidores ou serviços técnicos especializados (...). (...) sejam adotadas imediatas medidas judiciais e extrajudiciais no sentido de garantir a intangibilidade da área pleiteada pela comunidade (...), bem como viabilizar o acesso terrestre dos quilombolas à vila do Igarapé do Palha.

Segundo informações prestadas pelo INCRA/AP, foi contratada uma empresa para realizar os estudos relativos ao relatório antropológico da comunidade. A Ordem de Serviço com a autorização para início dos trabalhos foi assinada no início de 2017.

No que se refere ao pleito da Comunidade Lagoa dos Índios (Processo INCRA 54350.000348/2004-98), localizada na zona urbana do município de Macapá/AP, destaca-se que o MPF/AP moveu a Ação Civil Pública 2009.31.00.003552-7, com o objetivo de salvaguardar o direito de propriedade da comunidade. Aponta ainda para a necessidade de impedir que a Prefeitura de 
Macapá conceda autorização e que terceiros construam na área ao longo do ramal do Goiabal, que dá acesso à vila de Lagoa dos Índios, sustentando que somente assim seria possível

(...) estipular limites à expansão desenfreada da ocupação urbana patrocinada pelo mercado imobiliário no local, onde estão, inclusive, sendo construídos empreendimentos residenciais, o que certamente tornará o processo de regularização fundiária ainda mais lento e mais caro ao Poder Público, em função da necessidade de indenização das propriedades particulares.

Segundo relato da representante da CONAQ/AP, tal situação se tornou mais complicada devido ao fato que

Lagoa dos Índios não aceita o trabalho que a antropóloga Dra. Socorro fez lá. Não aceitam. E insistem em dizer que o trabalho da Socorro tá errado. Os mais velhos foram morrendo nesses 11 anos sem ver o título. A morosidade dentro do INCRA impede. Há uma revolta principalmente com esse pessoal do Terra Legal (INCRA), por que entraram no território e mexeram no piquete. (...)

Há que se ressaltar, porém, que a comunidade de Lagoa dos Índios é marcada pela falta de coesão entre seus membros quanto à titulação como território quilombola. Segundo a representante da CONAQ/AP, tem uma família dentro da Lagoa dos Índios que não aceita, porque tem uma parte de açaizal e de um igarapé, que nunca o INCRA vai conseguir titular. A fala da representante do movimento quilombola é coerente com o que assevera Vargas e Bastos (2013, p. 286):

Na luta em torno do território da Lagoa, cada grupo tenta impor sua visão de mundo procurando legitimar suas representações da realidade, para assim garantir a continuidade da sua forma de apropriação dos recursos e, portanto, de uso do território. Contudo, é interessante frisar que os grupos possuem formas de ação diferentes e que cada um procura utilizar a seu favor os elementos materiais e simbólicos à sua disposição, de acordo com o lugar que ocupam no espaço dessas relações. Só que as assimetrias de poder e os interesses conjunturais determinam o rumo e, até, o desfecho das ações que, dessa maneira, favorecem os agentes mais poderosos.

Vargas e Bastos (2013, p. 286) são firmes ao concluir que o poder público, via 
políticas públicas e agentes institucionalizados, devem assumir posições menos omissas e mais justas com os agentes sociais com direitos legítimos sobre esses territórios. Segundo informações repassadas pelo INCRA/AP, um antropólogo do INCRA/SEDE foi nomeado para a elaboração de um novo relatório antropológico e os trabalhos estão em andamento.

O conflito, que envolve a Comunidade Santo Antônio do Matapi (Processo INCRA 54350.000120/2014-70) motivou a Recomendação MPF/AP no 46 de 2015, que trata do conflito iniciado, a partir da instalação de uma cerca e do consequente impedimento do acesso dos quilombolas aos açaizais localizados na margem direita do rio Matapi, que são tradicionalmente extraídos pela comunidade, que está localizada à margem esquerda do referido rio.

A Recomendação conclui pela adoção, por parte do INCRA, de medidas que visem a conclusão do procedimento de titulação das terras da comunidade quilombola, assim como medidas judiciais e extrajudiciais no sentido de garantir a intangibilidade do possível território pleiteado (...) para viabilizar o acesso daquela comunidade aos recursos naturais, no caso, a extração de açaí, na margem direita do rio Matapi.

Sobre a Comunidade São Miguel do Macacoari (Processo INCRA 54350.000254/2012-29), o Relatório da CPT (2015) aponta para 19 famílias ameaçadas de expulsão e 01 família ameaçada de despejo por um empresário local. Relato do Padre Sisto, integrante da CPT/AP, esclarece que

(...) trata-se de uma área em fase de reconhecimento de quilombo que tem boa parte da área pretendida ocupada por empresários do agronegócio que promoveram vasta devastação com licenciamento do IMAP embora não tenha titularidade alguma nesta área. A devastação e plantio de soja chegam a cerca de 800 hectares. Os empresários fazem uso de agrotóxico envenenando as pessoas da comunidade e impedem o acesso a igarapé e áreas históricas de extração de açaí. O coordenador do Brasil Quilombola E.B. acompanha o conflito e identificou via SIGEF a presença de 7 invasores do sul do Brasil na área do futuro quilombo. (Padre Sisto, CPT/AP. Informação verbal)

Segundo informações prestadas pelo representante do INCRA/AP, o relatório antropológico que subsidiará o RTID da comunidade está sendo elaborado por uma 
empresa, que foi contratada pelo INCRA via pregão eletrônico, cuja Ordem de Serviço foi publicada no início de 2017.

A Recomendação MPF/AP 47 de 2015 trata de questão, que abarca a comunidade quilombola São José do Matapi (Processo INCRA54350.000014/201313) e o Instituto de Meio Ambiente e Ordenamento Territorial do Amapá (IMAP). Denuncia a comunidade quem, em 2012, o referido órgão fundiário procedeu o assentamento de 21 famílias na região do Matapi (rio), e nessa atividade, invadiu cerca de $270 m$ o território quilombola. O IMAP informou que as 21 famílias tratavam de posseiros selecionados para ocupação do assentamento Vitória Porto do Céu, bem como para a futura emissão das respectivas Autorização para Ocupação. O INCRA, por sua vez, manifestou-se via Relatório de Visita Técnica F4-01/2015 que

(...) uma área de aproximadamente 5,0000 ha do loteamento criado pelo Instituto de Meio Ambiente e Ordenamento Territorial (IMAP) estaria possivelmente sobreposta à área pretendida no processo de regularização fundiária do território quilombola de São José do Matapi.

Segundo informações repassadas pelo INCRA/AP, uma antropóloga do INCRA/MG foi nomeada para a elaboração do relatório antropológico, o que subsidiará as demais peças técnicas do RTID, dessa forma os trabalhos estão em andamento.

A comunidade Torrão do Matapi foi certificada pela FCP, mas não consta Processo Administrativo no INCRA. Dados da CPT (2015) apontam que houve ameaça/tentativa de expulsão de 35 famílias quilombolas por parte de um empresário. Relatos do Padre Sisto dão conta também de uma denúncia que

(...) dizia respeito a várias áreas que estavam sendo desmatadas, áreas do vizinho assentamento do Monte Sinai. O desmatamento estava sendo realizado por vários madeireiros de Macapá e Santana. Após denúncia houve fiscalização e o desmatamento parou; contudo a buraqueira ficou sem que ninguém de fato fosse punido. Um dos madeireiros envolvidos no desmatamento foi o senhor SPM e a firma do irmão dele JAPM com várias ações judiciais promovidas na Justiça Federal pelo IBAMA contra os mesmos e acessíveis pelo site do TRF1. (Padre Sisto, CPT/AP. Informação verbal) 
A Comunidade de Ariri consta na lista de comunidades quilombolas elaborada pela CONAQ/AP, mas não foi certificada pela FCP e, consequentemente, não há processo administrativo instaurado no INCRA. Sobre o conflito que a envolve, o Relatório da CPT (2015) aponta que 20 famílias sofreram ameaça e tentativa de expulsão por um empresário. Padre Sisto, integrante da CPT/AP esclarece que

(...) trata-se de um conflito entre a família R. cujos membros são pessoas bem sucedidas em Macapá e agora reivindicam a área ocupada há mais de 50 anos atrás pelos avós deles, área (da União) que atualmente é ocupada por outros moradores alguns dos quais parentes deles. O que a família $R$. quer é arrendar a área para 0 agronegócio da soja. Aproximadamente 500 hectares já estão sendo indevidamente usados pelo agronegócio com licenciamento do IMAP. Tudo isso é motivo de denúncia da PRODEMAC. Contudo o plantio acontece normalmente sem que ninguém iniba isso. (Padre Sisto, CPT/AP. Informação verbal)

A Comunidade Bacaba do Maruanum consta na lista de comunidades quilombolas elaborada pela CONAQ/AP, mas não foi certificada pela FCP e, consequentemente, não há processo administrativo instaurado no INCRA. Segundo CPT (2015), 06 famílias sofreram ameaças de despejo. Padre Sisto, integrante da CPT/AP, via correio eletrônico, esclarece que

(...) em relação ao conflito de Bacaba do Maruanum, ele acabou pois a pessoa que ateou fogo às casas se retirou pelo menos momentaneamente. Na época a polícia do posto de Maruanum se deslocou ao lugar, boletim de ocorrência foi registrado. A pessoa que teve a casa queimada chegou a entrar na justiça contra o ateador de fogo, mas em seguida as coisas se acalmaram e o juiz extinguiu 0 processo por falta de interesse das partes. (Padre Sisto, CPT/AP. Informação verbal)

\begin{tabular}{|c|c|c|c|c|}
\hline Cidade & Nome do Conflito & $\begin{array}{c}\text { No de } \\
\text { Famílias }\end{array}$ & Tipo de conflito & $\begin{array}{c}\text { Ator } \\
\text { envolvido }\end{array}$ \\
\hline Macapá & $\begin{array}{c}\text { Torrão do Matapi / Ramal } \\
\text { dos Maranhenses }\end{array}$ & 35 & $\begin{array}{c}\text { Tentativa / } \\
\text { Ameaça de } \\
\text { expulsão }\end{array}$ & Empresário \\
\hline Calçoene & $\begin{array}{c}\text { PARNA Cabo Orange / } \\
\text { Comunidades Vila Velha, } \\
\text { Taperebá e Cunani }\end{array}$ & 80 & Intimidação & $\begin{array}{c}\text { Governo } \\
\text { Federal }\end{array}$ \\
\hline Macapá & Conceição do Macacoari & 20 & Ameaça de & Empresário \\
\hline
\end{tabular}




\begin{tabular}{|c|c|c|c|l|}
\hline & & & despejo & \\
\hline Itaubal & São Miguel do Macacoari & 20 & $\begin{array}{c}19 \text { famílias: } \\
\text { ameaça de } \\
\text { expulsão } \\
01 \text { família: } \\
\text { ameaça de } \\
\text { despejo }\end{array}$ & Empresário \\
\hline Macapá & Ariri & 20 & $\begin{array}{c}\text { Tentativa / } \\
\text { ameaça de } \\
\text { expulsão }\end{array}$ & Empresário \\
\hline Macapá & $\begin{array}{c}\text { Maruanum, Santa Luzia, } \\
\text { Bacaba }\end{array}$ & 06 & $\begin{array}{c}\text { Ameaças de } \\
\text { despejo }\end{array}$ & \\
\hline
\end{tabular}

Quadro 08. Ocorrência de Conflitos envolvendo comunidades quilombolas - 2014 a 2015. Fonte: CPT (2015). Adaptado pelo autor.

O conflito registrado no município de Calçoene, que implica a comunidade quilombola do Cunani e o Parque Nacional do Cabo Orange - ICMBio, foi selecionado como objeto para estudo de caso no âmbito de nossa pesquisa, o que realizaremos no Capítulo VI.

\section{4 - A transferência das glebas de terras federais para o Estado do Amapá e suas consequências para as ações de titulação de terras quilombolas}

Uma nova era para a titulação das terras quilombolas no Amapá pode ter sido criada, a partir da publicação do Decreto 8.713 de 15 de abril de 2016, que regulamentou a transferência das terras da União ao domínio do Estado do Amapá. Para que se compreenda todo esse processo, é preciso considerar que, ao criar o Território Federal do Amapá, as terras que se encontravam devolutas foram discriminadas, arrecadadas e registradas em nome da União/INCRA. Por força da Constituição de 1988, houve a criação do Estado do Amapá, porém, sem a transferência do domínio das terras da União para o estado recém-criado. Assim, as glebas de terras públicas continuaram registradas sob o domínio da União/INCRA.

A União Federal só veio a criar um dispositivo para tratar efetivamente da transferência das terras para o Estado do Amapá, em 2009. O expediente utilizado 
foi dar nova redação à lei que havia transferido o domínio das terras federais para o Estado de Roraima, em 2001. Assim, ocorre a publicação do Decreto-Lei no 11.049 de 17 de junho de 2009, que alterou o texto da Lei $n^{0} 10.304$ de 05 de novembro de 2001.

Assim, para que se pudesse transferir o domínio das terras da União para o Estado do Amapá, seria necessário o cumprimento de diversas condicionantes, que foram estabelecidas no Art. $2^{\circ}$ da Lei 10.304 de 2001 :

São excluídas da transferência de que trata esta Lei: I - as áreas relacionadas nos incisos II a XI do art. 20 da Constituição Federal; II - as terras destinadas ou em processo de destinação pela União a projetos de assentamento; III - as áreas de unidades de conservação já instituídas pela União e aquelas em processo de instituição, conforme regulamento; IV - as áreas afetadas, de modo expresso ou tácito, a uso público comum ou especial; V - as áreas destinadas a uso especial do Ministério da Defesa; e VI - as áreas objeto de títulos expedidos pela União que não tenham sido extintos por descumprimento de cláusula resolutória.

O cumprimento dessas condicionantes não havia representado grandes problemas, quando da transferência de domínio da União para o Estado de Roraima, uma vez que à época, a transferência de domínio não implicava no georreferenciamento dos imóveis nos parâmetros exigidos pela Norma Técnica de Georreferenciamento de Imóveis Rurais, de 20 de novembro de 2003 - aplicada à Lei 10.267 de 28 de agosto de 2001 e ao Decreto 4.449 de 30 de outubro de 2002. Contudo, para que se fosse efetuada a transferência de domínio pelo Oficial de Registro de Imóveis, os limites das respectivas glebas deveriam ser georreferenciadas nos parâmetros exigidos pela legislação. Dada a extensão das glebas públicas localizadas no estado do Amapá, cujas dimensões chegam a atingir centenas de milhares de hectares, os trabalhos técnicos, a serem executados, exigiriam um grande esforço técnico, financeiro e humano jamais vislumbrado naquele estado.

Não bastasse essas dificuldades, também constituía como condicionante para a transferência do domínio das terras, a exclusão das áreas destinadas ou em processo de destinação pela União a projetos de assentamento, unidades de conservação, de uso militar e dos títulos de domínio particulares, já expedidos pela 
União. Como a maioria dos imóveis públicos não haviam sequer sido topograficamente demarcados e, consequentemente, sem destaque no registro da respectiva gleba pública federal, o Oficial de Registro de Imóveis ficou impedido de proceder a transferência de domínio desses imóveis, até que lhe fossem apresentadas as plantas e memoriais descritivos dos imóveis em questão (assim como das próprias glebas públicas das quais esses imóveis seriam destacados), em conformidade com que estabelecia a norma de georreferenciamento de imóveis rurais, já citada.

Dessa forma, criou-se um impasse jurídico-administrativo bastante peculiar, haja vista que, por força de decreto presidencial, as glebas públicas não mais pertenciam à União, mas ao Estado do Amapá que, por sua vez, estava impedido de destinar as áreas que o Decreto Ihe havia transferido, uma vez que tal transferência não havia sido efetivada nos registros cartoriais, onde o proprietário das glebas públicas ainda é a União/INCRA.

Como tentativa de resolver esse impasse, a então Presidente da República Dilma Rousseff assina, em 15 de abril de 2016, poucas horas antes do início da sessão na Câmara dos Deputados que autorizou a instauração do processo de impeachment da presidente, o Decreto no 8.713, que regulamentou a Lei no 10.304 . Diferentemente do Decreto de 2009, este instrumento faz menção explícita às terras quilombolas localizadas no Amapá pontuando que, quando da transferência das terras federais para o Estado do Amapá, deverão ser excluídos:

(...) territórios quilombolas já delimitados e aqueles a serem delimitados pelo Instituto Nacional de Colonização e Reforma Agrária - Incra por meio de relatório antropológico no prazo de vinte meses, contado da data de publicação deste Decreto, conforme o Anexo III (alínea "g" do inciso I do $\S 1^{\circ}$ do Art. $1^{\circ}$ do Decreto 8.713 de 2016).

Ademais, o texto do Decreto estabelece ainda que

O domínio das áreas a que faz referência a alínea "g" do inciso I do § $1^{\circ}$ que não forem delimitadas no prazo de vinte meses, contado da data de publicação deste Decreto, passará ao Estado do Amapá, a quem caberá efetuar a titulação dos territórios quilombolas nos 
termos do art. 68 do Ato das Disposições Constitucionais Transitórias (ADCT) e do Decreto n 4.887, de 20 de novembro de 2003.

Desta forma, estabeleceu-se, no contexto da transferência das terras para o Estado do Amapá, que as terras quilombolas que não forem delimitadas, ou seja, que não tenham sido objeto de elaboração de relatório antropológico que descreva os limites geográficos das áreas tradicionalmente ocupadas pelas comunidades quilombolas, deverão ficar a cargo do Governo do Estado do Amapá, que deverá adotar a legislação própria para demarcação e titulação dessas terras, o que está disposto na Lei Estadual № 1.505 de 23 de julho de 2010. De acordo com o estabelecido por essa legislação estadual:

Art. 3‥ Compete ao Instituto de Meio Ambiente e Ordenamento
Fundiário do Estado do Amapá (IMAP) as ações relativas à
identificação, reconhecimento, delimitação, demarcação e titulação
das terras ocupadas pelos remanescentes das comunidades dos
quilombos, sem prejuízo da competência concorrente dos
municípios.

No entanto, a análise que as lideranças dos movimentos quilombolas fazem a respeito das consequências das transferências das terras públicas para as ações de titulação das terras quilombolas no Amapá não é positiva. Afirmam, inclusive, que o IMAP tem assumido um papel de destaque como agente provedor de conflitos junto às comunidades tradicionais quilombolas, acusando a autarquia estadual de trabalhar intensamente pela defesa dos interesses dos grupos ligados ao agronegócio no Amapá. O representante da CPT/AP é enfático ao afirmar que

Os quilombolas tem muito medo do que vai acontecer quando o IMAP assumir a demanda quilombola no Amapá, pois o IMAP desde já está dando licenciamento a empresários dentro de áreas quilombolas, como acontece em São Miguel do Macacoari, Lagoa dos Índios, para o EP e JA na região do Ambé, na Conceição do Macacoari... E o IMAP já sinaliza que quando ele for titular, esse vai titular uma área quilombola bem reduzida, como por exemplo, só a vila da comunidade. O resto fica para o agronegócio. (...) O IMAP está com as garras afiadas para entregar essas terras nas mãos do agronegócio. Esse Decreto de repasse das terras não terá se 
resolvido em 20 meses, como você vai repassar essa atribuição para o IMAP? É uma covardia com as comunidades quilombolas. (Padre Sisto, CPT/AP. Informação verbal)

Consultado sobre a questão da transferência das ações de titulação das terras quilombolas para o IMAP, o representante do INCRA/AP destaca que

O MPF/AP tem cobrado do GEA uma reestruturação do IMAP para atuar na regularização de territórios quilombolas, uma vez que já tem uma legislação estadual desde 2010. O GEA sempre se diz pronto para realizar, mas a realidade é que essa estruturação do IMAP não ocorreu.

Entretanto, outra questão referente aos impactos causados pelo Decreto de 2016 nas ações de titulação das terras quilombolas do Amapá refere-se ao fato de que as comunidades que não tiverem seus perímetros delimitados pelo relatório antropológico até o mês de dezembro de 2017 terão os processos de titulação de suas terras remetidos do INCRA para o IMAP, para que o órgão estadual proceda a titulação. Assim, há uma corrida contra o tempo, para que a maior quantidade possível de relatórios antropológicos seja concluída até o prazo limite estipulado pelo Decreto, permitindo assim que o INCRA possa concluir tais procedimentos dentro de sua própria esfera de atuação.

Isso se deve, sobretudo, pela enorme possibilidade de que, uma vez findado o prazo de 20 meses e a transferência de domínio não tenha sido efetuada pelo Oficial de Registro de Imóveis (devido, especialmente, às dificuldades de realizar os trabalhos de georreferenciamento das glebas e imóveis públicos), as ações de titulação das terras quilombolas remetidas ao IMAP - bem como as que vierem a ser iniciadas no futuro- estarão inseridas no mesmo impasse jurídico-administrativo ocasionado pelo Decreto de 2009, nas ações de regularização fundiária das ocupações em terras públicas no Amapá: o INCRA não poderá titular as terras quilombolas localizadas nas glebas públicas por força do Decreto de 2016, que as transferiu para o Estado do Amapá, assim como o IMAP não poderá emitir os títulos às comunidades quilombolas em áreas que não pertencem ao seu domínio, pois nos livros do Serviço de Registro de Imóveis as glebas públicas estarão matriculadas ainda em nome da União/INCRA. 
As comunidades de Carmo do Maruanum I, Igarapé do Lago, Kulumbu do Patualzinho e Tapera, que não tiveram os trabalhos antropológicos iniciados até o momento de fechamento dessa pesquisa, são algumas das comunidades que, provavelmente, terão seus processos remetidos ao IMAP, a não ser que o INCRA/AP encontre alternativas para execução direta ou de contratação de empresas, para a elaboração dos respectivos relatórios antropológicos até dezembro de 2017. 


\title{
CAPÍTULO VI - A Comunidade Quilombola do Cunani: da invisibilidade social à busca pelo reconhecimento de direitos
}

\begin{abstract}
Nosso objetivo, nesse capítulo, consistirá na descrição, análise e avaliação das ações desempenhadas pelo poder público, na condução do processo de titulação das terras quilombolas da Comunidade de Cunani, especialmente, na perspectiva da garantia constitucional dos direitos às terras tradicionalmente ocupadas pela comunidade. Os procedimentos metodológicos que orientaram essa parte da pesquisa podem ser assim descritos:
\end{abstract}

- Revisão da literatura científica cujo objeto se volte à análise do impasse que abrange a comunidade e o Parque Nacional do Cabo Orange (PNCO), assim como do processo de regularização das terras da comunidade de Cunani;

- Deslocamento até o município de Calçoene e à Vila de Cunani para coleta de depoimentos de representantes e moradores da comunidade quilombola de Cunani, via entrevista semiestruturada, com registro de áudio;

- Coleta de depoimentos de agentes públicos envolvidos no processo, via correio eletrônico ou entrevista pessoal, com registro de áudio, conforme descrição realizada no capítulo anterior;

- Aquisição de cópia do processo administrativo de regularização das terras quilombolas (INCRA) e de documentos gentilmente cedidos pelas autarquias federais envolvidas e/ou disponibilizadas em sítios eletrônicos da rede mundial de computadores, que subsidiaram a análise e interpretação dos atos administrativos tomados pelo poder público na condução desse pleito;

- Identificação e análise de documentos, relatórios e manifestações, expedidas pelo MPF/AP e da CCAF e disponibilizadas em sítios eletrônicos da rede mundial de computadores e/ou gentilmente cedidos a esse pesquisador;

- Coleta de depoimentos, via entrevista semiestruturada com registro de áudio e revisão de documentos, notas e manifestações de organismos da sociedade civil, que se dedicam à questão quilombola no Amapá, como a CONAQ/AP e CPT/AP, descritas no capítulo anterior. 
A respeito da coleta de depoimentos realizadas para subsidiar especificamente a discussão proposta nesse capítulo, foram entrevistadas duas lideranças da Associação que representam os quilombolas de Cunani:

- Sr. Domingos Ramos Damasceno - Presidente da Associação dos Moradores Remanescentes de Quilombolas do Cunani, residente na zona urbana do município de Calçoene. Também esteve presente e contribui, com seus relatos e opiniões, o Sr. Eronildo José Costa Cordeiro, que é integrante da comunidade quilombola.

- Sr. Amâncio, liderança da comunidade de Cunani e vice-presidente da mesma Associação, que reside na Vila de Cunani. Esta entrevista foi realizada em sua própria residência, na área central da vila, próxima à escola. Nessa oportunidade, também esteve presente e contribuiu com seus relatos a Sra. Rosineia Damasceno dos Santos, moradora da Comunidade do Cunani e esposa do Sr. Amâncio.

As entrevistas foram realizadas no dia 24 de março de 2017.

\section{1 - As terras da comunidade quilombola do Cunani}

A comunidade quilombola do Cunani localiza-se às margens do rio de mesmo nome, na zona rural do município de Calçoene/AP, mesorregião do Norte do Amapá, microrregião de Oiapoque. A comunidade é formada por famílias que residem na histórica Vila do Cunani (encravada na margem esquerda do rio de mesmo nome) e por famílias que residem nas proximidades da vila.

O cadastro das famílias quilombolas, que é uma peça técnica do RTID elaborado pelo INCRA, identificou um total de 38 famílias. Mas as próprias lideranças da comunidade admitem que nem todas residem permanentemente na vila, pois a falta de oferta do ensino fundamental e médio faz com que a maioria das famílias seja forçada a se mudar para a sede do município, em Calçoene, para que 
as crianças e adolescentes possam estudar sem que a família tenha que se dividir. Essas famílias, porém, se deslocam de Calçoene em direção à Vila de Cunani nos finais de semana para trabalhar em suas roças de subsistência (especialmente banana e mandioca para produção de farinha), extração de açaí, cacau e pesca artesanal. Essa situação faz com que apenas cerca de 10 famílias tenham residência fixa na Vila.

O acesso à vila se dá pelo chamado ramal do Cunani, distante cerca de 54 quilômetros por estrada não pavimentada, desde a cidade de Calçoene. Nas épocas de maior pluviosidade, o tráfego por esse ramal é bastante prejudicado, devido a pouca manutenção da via, o que dificulta a circulação e comunicação dos moradores com o mundo exterior. Não há rede de energia elétrica ou sinal de telefonia móvel. Existem, aliás, dois telefones públicos instalados na parte central da vila, mas que se encontram permanentemente inoperantes, além de um conjunto moto-gerador movido à combustível fóssil, que é eventualmente obtido, via repasse da Companhia de Energia do Amapá (CEA), Prefeitura de Calçoene ou, principalmente, pela iniciativa dos próprios moradores em se reunir, para a compra coletiva com recursos próprios.

Atualmente, a falta de acesso à rede de energia elétrica é a maior queixa dos moradores da Vila de Cunani, haja vista que tal carência os impede de acomodar e conservar adequadamente as mercadorias produzidas no local, como pescado e polpa de frutas, além de representar um total isolamento com o mundo pois, sem energia elétrica, destacam, não conseguem acesso aos noticiários da programação radio-televisiva.

A comunidade entende que essa situação ainda perdura devido às históricas restrições impostas pela administração do $\mathrm{PNCO}$, que vetou em vários momentos as iniciativas de oferta de eletricidade à vila, inclusive no contexto do Programa Luz para Todos, recentemente implantado no Amapá, por iniciativa do Governo Federal. A perspectiva dos moradores, porém, é que se consiga em breve solucionar essa questão, bastando que o Governo do Estado do Amapá (GEA) consiga concluir a licitação para contratar uma empresa, que execute as obras necessárias. Segundo as lideranças da comunidade e, de acordo com os representantes do GEA, houve duas tentativas de licitação, realizadas para a execução da obra, mas nenhuma empresa se interessou pelo serviço. 
Não há circulação de carros ou motocicletas na vila de Cunani, uma vez que não há uma ponte fixa que ligue as duas margens do rio. Desta forma, os moradores são obrigados a deixar seus veículos na margem direita do curso d'água e atravessar a pé pela longa e estreita ponte de cabos de aço que corta o leito do rio. Em épocas, em que o rio Cunani está muito cheio, devido aos grandes volumes de chuvas, combinados com a maré alta, a única opção é usar uma pequena embarcação de madeira, por eles denominada "montaria" para atravessar o rio e ter acesso à vila. Esta, inclusive, foi a alternativa encontrada por este pesquisador no seu último deslocamento à Cunani.

Além dos problemas causados pela falta de fornecimento de energia elétrica, os moradores de Cunani se queixam das restrições impostas no passado pelo IBAMA/ICMBio no sentido de proibir a construção de novas casas na comunidade. Nas palavras de um morador da comunidade, essa "humilhação" só cessou recentemente, quando um juiz federal visitou a comunidade e, em sua decisão sobre um pleito do MPF/AP, resolveu pelo direito dos cunanienses de construir suas moradias na vila, o que é motivo de muita alegria e orgulho para a população e que foi registrada nas entrevistas realizadas por esse pesquisador.

Outra queixa da comunidade é em relação ao abastecimento de água potável, bastante prejudicado no período da estiagem, período em que os poços escavados (popularmente conhecidos na região como "poços amazonas") não suprem as demandas dos moradores e a água do rio Cunani fica inapta para o consumo humano devido à influência das águas salgadas do oceano.

\section{2 - O Parque Nacional do Cabo Orange (PNCO)}

No que se refere ao PNCO, destaca-se que o mesmo foi criado pelo Decreto n 84.913, de 15 de julho de 1980 e localizado no município de Oiapoque, extremo norte do então Território Federal do Amapá, hoje Estado do Amapá. O PARNA do Cabo Orange, como é conhecido, conta com uma área estimada de 619.000 ha, foi inicialmente subordinado ao Instituto Brasileiro de Desenvolvimento Florestal (IBDF), depois ao Instituto Brasileiro do Meio Ambiente (IBAMA) e, atualmente, ao Instituto Chico Mendes (ICMBIO). Informa o decreto que a área em questão é constituída por 
terras da União e que tinha, por finalidade precípua a proteção da flora e da fauna e das belezas naturais existentes no local, ficando sujeito às disposições da Lei no 4.771 de 1965 e do Regulamento dos Parques Nacionais Brasileiros (Decreto no 84.017 de 1979).

Nos termos da legislação que o rege, o PNCO é uma unidade de conservação de proteção integral, ou seja, voltada exclusivamente para a manutenção dos ecossistemas livres de alterações causadas por interferência humana. Admite apenas 0 uso indireto dos seus atributos naturais e veta, portanto, o desenvolvimento de atividades de exploração econômica, como extrativismo, agropecuária, caça e pesca, por exemplo.

\title{
6.3 - Uma sobreposição de interesses institucionais ou violência territorial?
}

Para que se compreenda a controvérsia entre a Comunidade de Cunani e o PNCO é de grande relevância o trabalho de Melo (2007), especialmente por registrar a impressão da comunidade e da administração do Parque, a respeito do conflito em meados da década de 2000. Ao aprofundar sua investigação, relacionada à leitura que a comunidade fazia, à época, a respeito da sua possível retirada da área sobreposta ao Parque, Melo (2007) afirma que

\begin{abstract}
As tensões em relação à hipótese de retirada da população do parque, de acordo com os relatos obtidos pela pesquisa, são potencializadas pela falta de informações oficiais transmitidas a respeito deste assunto. Mesmo as informações transmitidas pelos funcionários IBAMA, sob a ótica dos habitantes de Cunani, não são consideradas "confiáveis", pois estes alegam que cada funcionário passa aos moradores uma notícia diferente em relação à possível retirada dos habitantes locais, por registrar a leitura da comunidade de Cunani em relação à gestão do Parque Nacional do Cabo Orange. (MELO, 2007, p. 90)
\end{abstract}

$\mathrm{Na}$ visão da comunidade, os reais interesses do IBAMA (atualmente ICMBio) em relação à retirada da comunidade da área se deveria não exclusivamente ao interesse pela proteção ambiental: 
(...) a principal especulação dos habitantes locais em relação à sua possível remoção daquela área é que esta ação está relacionada ao interesse do IBAMA em "explorar", futuramente, as riquezas do parque. Desta forma, o papel do IBAMA, enquanto órgão que visa, entre outros aspectos, proteger a natureza e contribuir para a utilização dos recursos naturais em bases sustentáveis, parece não ser bem reconhecido pelos locais. (MELO, 2007, p. 90).

Melo (2007) conclui ainda que o principal argumento da comunidade, para sua permanência na área, fundamenta-se no fato de que o Parque foi criado sem considerar a presença das populações que ali residiam há várias gerações, inclusive salientando que Cunani tem uma rica história. Tão rica e importante que pode ser resumida na fala de um entrevistado, ao asseverar que em se tratando da região de Cunani, não há história do Amapá sem antes falar de Cunani. (MELO, 2007, p. 91).

No que se refere às restrições impostas pelo PNCO em relação aos recursos ambientais, Melo (2007, p.92) destaca que a comunidade não relatou nenhuma proibição à plantação de roças, pesca e caça de subsistência, mas se mostraram apreensivas por essa possibilidade, pois na comunidade vizinha, denominada Taperebá, inserida no interior do Parque, essas restrições foram impostas aos moradores.

Considerando a insegurança em relação à eventual proibição do uso
dos recursos naturais, os habitantes locais argumentam que seus
meios de produção estão diretamente ligados à subsistência e que,
apenas a parte excedente da produção é comercializada. Além disso,
mesmo a parte destinada à venda, de acordo com os habitantes
locais, não traz lucro significativo já que não há transporte regular
para que os produtos cheguem à cidade de Calçoene, onde são
comercializados. Esta dificuldade é interpretada como um ônus para
a comunidade. (MELO, 2007, p. 92-3)

Melo (2007) relata ainda a posição da comunidade sobre a necessidade de reconhecimento, por parte do IBAMA (atualmente ICMBio), do seu papel de protagonista na tarefa de proteção ambiental dos recursos encontrados na área. Por fim, o autor chama atenção para um, então, recente "escudo de proteção" (2007, p. 96) que poderá ser utilizado pela comunidade de Cunani para sua permanência na área, que é a titulação das terras reivindicadas, com fundamento no Decreto 4.887 de 20 novembro de 2003. 
Esta questão abrange uma nova discussão em políticas públicas de proteção da natureza no âmbito do PNAP, em relação à hierarquização entre as unidades de conservação e as terras remanescentes de quilombo. É importante ressaltar que o processo de reconhecimento de Cunani como remanescente das comunidades de quilombo, de acordo com um habitante local, encontra-se em andamento, mas ainda não houve uma definição legal a respeito. (MELO, 2007, p. 95)

Outro trabalho de relevância para a compreensão do tema é a tese desenvolvida por Kornijezuk (2012), no âmbito das pesquisas sobre Desenvolvimento Sustentável. Ao comparar a gestão dos PNCO e o Parque Nacional Vanoise - PNV (França), a autora conclui que

O PNV tem a sua gestão direcionada à tentativa de conciliação entre o desenvolvimento regional e a preservação dos patrimônios natural e cultural. Esse paradigma foi definido com a Lei 436, de 14 de abril de 2006, para Parques Nacionais, Parques Naturais Regionais e Parques Naturais Marinhos. Está sendo proposta uma visão de território e de futuro que seja compartilhada pelo parque e pelos stakeholders. A renovação jurídica expressa na lei supracitada e a construção participativa das cartas magnas dos parques nacionais são as maiores expressões do paradigma Integrado em APs francesas. Esta lei aproxima os parques nacionais das outras categorias de áreas protegidas, como os parques naturais marinhos e os parques naturais regionais. Isso ocorre porque ela prevê a participação dos atores na definição das políticas de conservação. Além disso, é dada às comunidades a escolha de permanência no parque. No caso do PNV, grande parte das comunidades já sinalizou pela sua exclusão. O PNCO é conservador da biodiversidade, em sentido restrito. A legislação para parques nacionais brasileiros prevê a conservação de ecossistemas naturais de grande relevância ecológica e beleza cênica. A presença humana deve ser excluída. Essa estratégia é considerada correta, para a presente tese, visto que, no Brasil, há espaço para o desenvolvimento e também para a preservação, pois praticamente metade de todo o território nacional (46\%) ainda está disponível para a agricultura (DRUMMOND, 2012). O Brasil, palco de uma política territorial geofágica (DROULERS, 2001) ou de frente de expansão (MARTINS, 2009), pode promover o seu desenvolvimento econômico e reduzir as desigualdades sociais. Mas, há espaço geográfico também para a conservação da biodiversidade, em sentido restrito. (KORNIJEZUK, 2012, p. 134)

Kornijezuk (2012) questiona ainda possibilidade de conciliação entre o desenvolvimento humano e a proteção da biodiversidade dentro dos parques 
nacionais analisados, sustentando que essa possibilidade parece ainda ser impossível no caso do PNCO, pois sua biodiversidade é um patrimônio ainda desconhecido. Por outro lado, a pesquisadora ressalva que:

O Brasil empenha um louvável esforço para manter a sua biodiversidade, mas não é justo que populações circundantes aos parques arquem individualmente com os passivos da conservação ambiental, cujos benefícios sãos difusos. (KORNIJEZUK, 2012, p. 135).

Mello (2003, p. 345-6), ao analisar os desafios institucionais representados pela superação de paradigmas no âmbito da gestão das políticas ambientais, salienta que:

\begin{abstract}
No período de duas décadas, as políticas ambientais se transformaram. Em seu início estiveram fundamentadas no controle ambiental e de proteção de áreas e, no final dos anos 1990, passaram à difusão de instrumentos de ordenamento territorial, bastante conhecidos nas esferas de planejamento. Mas, com um novo potencial, por terem incorporado elementos da dimensão ambiental. A recolocação desse instrumento no seio do debate ecologista como solução ao ordenamento do desenvolvimento, sobretudo o amazônico, foi além de suas próprias capacidades e ainda hoje há imenso imbróglio teórico-metodológico e institucional. A ação pública federal tem privilegiado a proteção de territórios à escolha de outros modelos preventivos de ordenamento, investindo em programas que visam o estabelecimento de novas unidades de conservação.
\end{abstract}

Kornijezuk (2012) avalia que existem formas de se conferir sustentabilidade social ao PNCO e aposta no ecoturismo, cujo sucesso dependerá, entretanto, de uma integração entre os atores sociais do projeto, da melhoria das condições de alojamento para os potenciais turistas e da divulgação do projeto em mercados-alvo. (KORNIJEZUK, 2012, p. 135).

O trabalho de Lima e Jucá (2015), intitulado "O Novo Contestado", faz referência às disputas estabelecidas entre França e Portugal/Brasil e àquela entre a Comunidade de Cunani e o PNCO. A Questão do Amapá ou do Contestado, se dava 
pela controvérsia a respeito da identificação do rio Vicente Pinzón, mencionado no Tratado de Utretch (França/Portugal, 1713): para a França, o rio, citado em Utrech, seria o Araguari, enquanto que, para o Brasil, seria o rio Oiapoque. A questão foi resolvida por meio de arbitragem realizada pelo Governo Suíço, em dezembro de 1900, ao qual o Brasil saiu vencedor e os limites entre os dois países foram estabelecidos no rio Oiapoque e não o rio Araguari, como queriam os franceses. Sobre o Novo Contestado, Lima e Jucá (2015) afirmam que

\begin{abstract}
Possibilidades para a resolução do conflito aconteceram sem que a comunidade tivesse sido comunicada, dentre elas estão: a diminuição da área da comunidade, a criação de uma Reserva de Desenvolvimento Sustentável. Os "filhos de Cunani" já se posicionaram rejeitando qualquer proposta que diminua a sua área ou desloque a vila de onde se encontram desde sua origem. Quanto a este tema, em audiência, a gestão do PNCO deixou claro que não tem proposta de realocar ou remover a comunidade do seu território. Essa afirmação é recebida com alegria, mas não tranquiliza a comunidade por saberem que muitas decisões são tomadas na esfera federal, temendo que os debates locais sejam ignorados e decisões sejam tomadas a revelia da comunidade. (LIMA e JUCÁ, 2015, p. 81)
\end{abstract}

Outro ponto de muito destaque na pesquisa de Lima e Jucá (2012) é a identificação, no discurso dos quilombolas, da irredutibilidade do direito da comunidade de continuar utilizando a terra tradicional e seus recursos (caça, pesca, agricultura de subsistência, extrativismo etc.), segundo seu modo de vida secular.

Uma vez que a comunidade precisa se adequar às restrições
estabelecidas pela especificidade da UC de proteção integral, suas
práticas ficam submetidas a regras e normas que não foram
estabelecidas pelo grupo e este perde a autonomia sobre o seu
território. Com a titulação de suas terras, a comunidade espera
resgatar o poder sobre o seu território (...). (LIMA e JUCÁ, 2015,
p.82)

Outra preocupação da comunidade, registrada por Lima e Jucá (2015), referese ao impedimento, por parte do PNCO, de se efetuarem melhorias de infraestrutura na Vila de Cunani, como abastecimento de água, energia elétrica e acesso viário 
(estradas e ponte sobre o rio Cunani), por exemplo. Por parte da Chefia do PNCO, Lima e Jucá (2015) registrou, basicamente, duas preocupações: a primeira em relação à ocorrência do mineral manganês, na área do território pleiteado, e sobreposto ao PNCO, uma vez que não há garantias de como se dará uma eventual exploração desse recurso mineral no futuro e as consequências dessa exploração tanto para o PNCO quanto para a própria comunidade; a segunda preocupação consiste na possibilidade de a comunidade perder seu modo de vida tradicional, a partir do momento em que receber de volta seus "filhos" que foram para as cidades e/ou que tiverem acesso à informação, vinda do resto do mundo, a partir das parabólicas e internet, que invadem suas casas e mentes com desejos de consumo que há pouco tempo atrás, eles nem sabiam que existiam. (2015, p. 87).

\section{4 - Da sobreposição territorial à invisibilidade social: Conhecendo o processo de regularização do território da comunidade de Cunani}

Quando se procede a análise, o memorial descritivo que consta no decreto de criação do PNCO, nota-se que a vila da comunidade do Cunani foi identificada, mas não devidamente considerada, conforme indica o trecho do memorial descritivo:

(...) subindo o rio Cassiporé, pela sua margem direita, até a picada que liga as localidades de Vila Velha a Cunani; segue, no rumo sul, numa distância aproximada de $45 \mathrm{~km}$, até o rio Cunani, donde continua, através de uma linha seca, no sentido oeste-leste, até 10 $\mathrm{km}$ da costa no oceano Atlântico (...)".

Assim como foi historicamente negligenciada pelo INCRA em suas políticas de regularização fundiária, é possível concluir que seus direitos, enquanto comunidade tradicional, sobretudo o direito à terra, foram também negligenciados pelo decreto 84.913/1980, que criou o PARNA do Cabo Orange, mesmo tendo detectado a existência daquela comunidade em seus limites. Contudo, desde a publicação do decreto $84.913 / 1980$ não foi tomada nenhuma medida efetiva para a retirada das famílias que residem na vila.

A questão ganha novos contornos, quando o governo federal publica o 
Decreto 4.887/2003, que estabeleceu os procedimentos administrativos para a identificação, o reconhecimento, a delimitação, a demarcação e a titulação da propriedade definitiva das terras ocupadas por remanescentes das comunidades dos quilombos, de que trata 0 artigo 68 do Ato das Disposições Constitucionais Transitórias, fundando as bases para a criação, em maio de 2004, do Programa Brasil Quilombola - PBQ. Com o objetivo de implantar as ações necessárias à otimização e aplicabilidade desse decreto, foi constituído um grupo de trabalho pela Superintendência Regional do INCRA, no Amapá, que, em conjunto com o Conselho de Comunidades Quilombolas do Estado do Amapá (CONAQ/AP), atuou no levantamento de informações sobre áreas remanescentes de quilombos, no referido estado.

Como fruto desse trabalho, surge a possibilidade de iniciar-se o processo de regularização do território quilombola da comunidade do Cunani. Dessa forma, o processo administrativo foi formalizado no INCRA, de ofício, a partir do MEMO/INCRA/SR(21)GT/N007/2004, de 22 de março de 2004, objetivando a efetivação das ações de identificação, reconhecimento, delimitação, demarcação e titulação das terras ocupadas, o que deu origem ao processo administrativo INCRA SR(21)AP/54350.000346/2004-07.

Cabe ressaltar, neste momento, que a elaboração desse debate só foi possível devido à disponibilização, por parte da Superintendência Regional do INCRA no Amapá, de uma cópia digital do Processo Administrativo INCRA/SR21/AP/no 54350.000346/2004-07, que trata da Identificação, Reconhecimento, Delimitação, Demarcação e Titulação de Terras ocupadas pela Comunidade Quilombola do Cunani, doravante denominado simplesmente como Processo Administrativo INCRA. Quando nos foi disponibilizada a cópia do processo, o mesmo contava com 574 páginas distribuídas em 03 volumes.

A primeira manifestação efetiva da comunidade de Cunani, no processo em questão se deu a partir do Ofício no 104/2004, datado de 16 de setembro de 2004 e emitido pela Associação da Comunidade do Cunani, que solicita o reconhecimento e a titulação da área da referida comunidade:

(...) pois trabalhamos desde 1845 , com atividades agrícolas e extrativistas e nunca recebemos nenhum tipo de benefício e sim 
perdendo aos poucos nossas raízes culturais e religiosas pela entrada de outros povos em nossas áreas.

O processo administrativo de regularização das terras quilombolas da Comunidade de Cunani foi formalizado no INCRA em 23 de março de 2004, um dia antes da publicação da IN/INCRA 16, que foi o primeiro instrumento normativo do Decreto 4.887, que havia sido publicado em 20 de novembro de 2003. Tratava-se, portanto, de um cenário de transição ainda muito incipiente, em que o INCRA se preparava nos fundamentos mais básicos, para o recebimento dessa demanda. Assim, em 02 de Setembro de 2004 se deu o primeiro deslocamento de uma equipe do INCRA até a comunidade, para realização dos trabalhos com vistas à titulação da terra. Tratava-se da apuração de uma denúncia de invasão de terras da comunidade, mas que ao final da visita técnica, constatou-se estar fora dos limites reivindicados pela comunidade e do PNCO.

É interessante notar que, num ofício assinado pela Superintendente do INCRA no Amapá ${ }^{9}$ endereçado ao Presidente da autarquia, solicita com urgência a visita de um técnico para "emissão de laudo para certificação da comunidade como área de remanescente de quilombo", relatando urgência em seu pedido, pois havia sido acordado o dia 20 de novembro de 2004 (dia da Consciência Negra) como a data para a titulação da área. Evidentemente, havia pressa para que o pleito da comunidade do Cunani fosse cumprido até essa data simbólica.

No dia 27 de outubro de 2004, ocorreu uma reunião na comunidade do Cunani onde se discutiu a solicitação feita pela comunidade ao INCRA, para reconhecer a área como remanescente de quilombo ${ }^{10}$. Sobre essa reunião, a Sra. Rosineia, moradora da comunidade do Cunani recorda que

Fizeram uma reunião com o pessoal do INCRA, na época do IBAMA, para demarcar a área do quilombo. Aí o chefe do Parque chegou aqui no meio da reunião e chorou, chorou mesmo, por que ele não queria que demarcasse, porque ele achava a área muito grande, mas o Incra demarcou. (Sra. Rosineia, Com. Cunani. Informação verbal).

\footnotetext{
9 OFICIO/INCRA/SR(21)/AP/G/N825/04, de 20 de outubro de 2004. Folha 63 do Processo Administrativo.

10 Ata da Reunião da Associação dos Moradores e Agricultores da Comunidade de Cunani. Folha 129 do Processo Administrativo.
} 
Em 05 de novembro de 2004, ocorre a primeira comunicação formal entre INCRA e o então IBAMA, a respeito da questão que abrange a comunidade quilombola e o PNCO. Tratou-se de uma solicitação de envio de uma cópia do Decreto de Criação e Memorial Descritivo da unidade de conservação ${ }^{11}$.

Em 06 de novembro de 2004, ocorreu uma reunião na comunidade de Cunani, para que a equipe do INCRA apresentasse à comunidade o resultado de uma reunião realizada em Macapá, com os técnicos do IBAMA, sobre a ampliação da área do Cunani $^{12}$. Desta reunião, a comunidade definiu unanimemente que seu posicionamento, perante a questão com o IBAMA, seria pelo território até o Igarapé Grande, mas se não for possível atendê-la, aceita recuar até o Tralhoto.

Essa definição subsidiou a elaboração de uma planta, que comportava duas propostas de delimitação do território quilombola, identificando uma área no extremo norte do território que se estendia até o Igarapé Grande Crique, o que foi denominado pela equipe técnica responsável pelos trabalhos como área pretendida a mais pela comunidade no Parque Nacional do Cabo Orange, que media 12.471,4122 ha, bem como a definição de um segundo polígono, que considerava como limite o sul do Lago do Tralhoto, que media 36.156,5152 ha, sendo 22.1831,23 sobrepostos ao PNCO. Considerando o "plano A" da comunidade, caso conseguisse titular toda a área reivindicada, somar-se-ia uma área total de 48.627,9274 ha. A planta elaborada pela equipe técnica do INCRA em conjunto com a comunidade pode ser visualizada na Figura 08:

\footnotetext{
$\overline{11}$ OFÍCIO/INCRA/GAB/N.866/04 de 05 de novembro de 2004. Folha 164 do Processo Administrativo. 12 ATADA REUNIÃO NA COMUNIDADE DE CUNANI de 06 de novembro de 2004. Folha 166 do Processo Administrativo.
} 


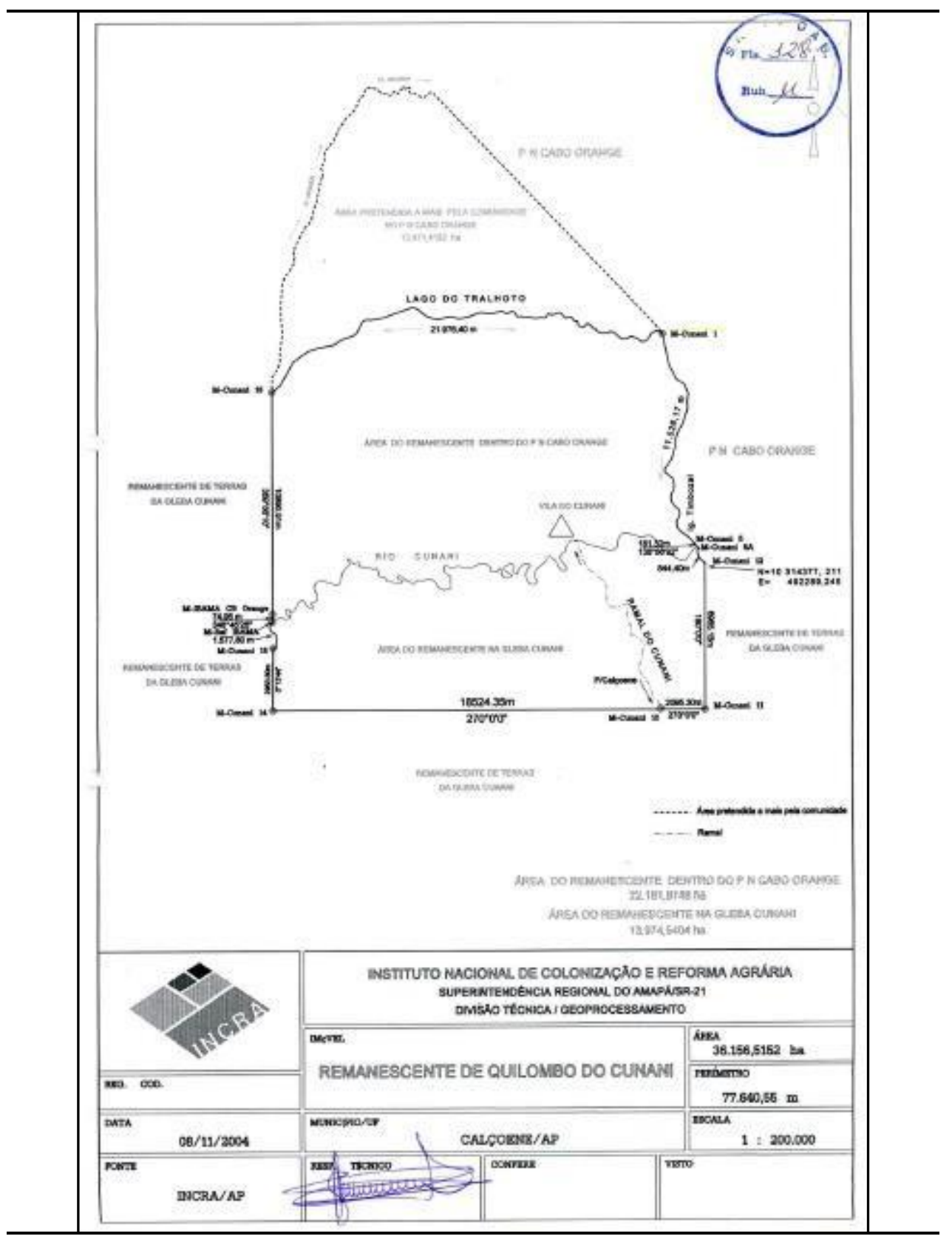

Figura 08: Primeira proposta de delimitação do Território Quilombola do Cunani. Fonte: Processo Administrativo INCRA, folha128.

A questão chave, que abarca a área que se estende do Lago do Tralhoto até o Igarapé Grande Crique é a existência em seu interior de uma antiga jazida de manganês. Esse ponto foi, no começo, motivo de estabelecimento de mais um impasse entre a comunidade e o IBAMA/ICMBio, como nos relata o sr. Amâncio: 
Tem uma jazida de manganês ai pra trás e eles pensaram que a gente ia explorar. Só que a gente fez um acordo e eles ficaram com a jazida pra lá, que desde 1885 nunca foi explorada. Por que agora ia explorar? (Sr. Amâncio, Com. Cunani. Informação verbal)

Sr. Domingo, por sua vez, pondera que

Mas hoje eu sou contra isso (jazida de manganês no território quilombola), por que o manganês fica nas cabeceiras dos igarapés e se não tiver uma forma de tratar o resíduo podia poluir os igarapés igual ao Tralhoto, pois essas terras são como no Pantanal do Mato Grosso, se vazar um pouquinho de resíduo... (Sr. Domingos, Com. Cunani. Informação verbal)

Assim, em 03 de dezembro de 2004, foi remetida à Divisão Técnica do INCRA o "Parecer Técnico sobre o Remanescente de Quilombo do Cunani". Esse documento trouxe como proposta de área, reivindicada pela comunidade, um total de 36.156,5152 ha, dos quais 22.181,2297 inseridas dentro dos limites do PNCO, tendo o Lago do Tralhoto como o limite no extremo norte do território reivindicado. Essa decisão foi referendada por unanimidade pela Comunidade do Cunani, a partir da Ata de reunião realizada no dia 02 de dezembro de 2004 (Processo Administrativo INCRA, folha 169).

Em 13 de janeiro de 2005, o processo administrativo segue para a então Superintendência Nacional de Desenvolvimento Agrário (SD), para análise e apreciação, com pedido da superintendente regional do INCRA no Amapá por agilidade por tratar-se de matéria do mais alto interesse desta $S R$, bem como uma das ações prioritárias do INCRA ${ }^{13}$.

Ocorre que, em 17 de junho de 2005, fez-se juntar ao processo administrativo um parecer técnico emitido pela equipe do IBAMA/AP intitulado Parecer Proposta de Criação de Área de Remanescente de Quilombo que trata de uma proposta da Gerência do PNCO de que a área desafetada dos limites do PNCO em favor da comunidade seja reposta pelo INCRA em áreas de relevância ambiental e estratégica na região do entorno da unidade de conservação. Dada a 


\section{importância desse documento para nossa análise, disponibilizamos seu conteúdo na íntegra na Figura 09:}

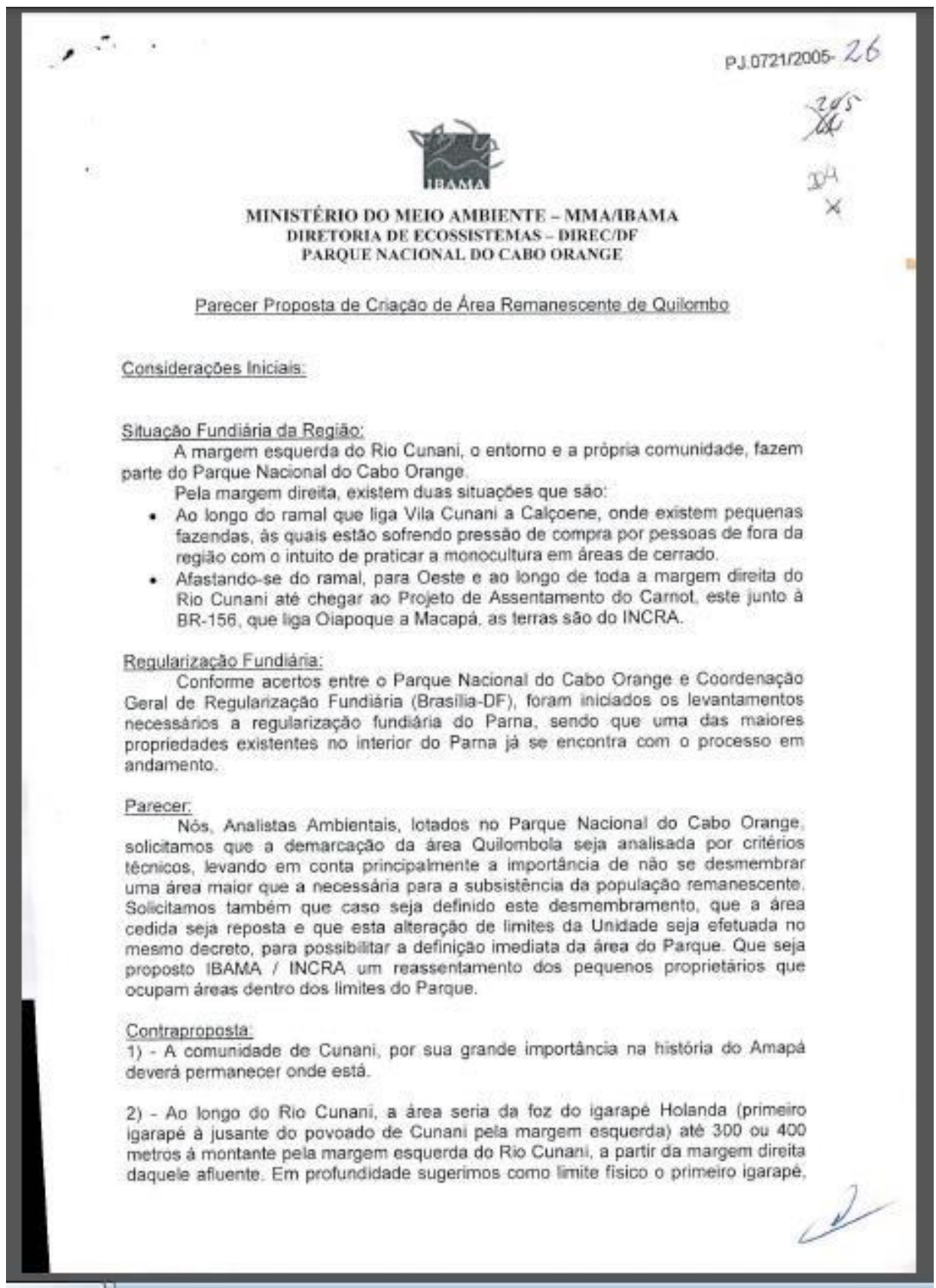




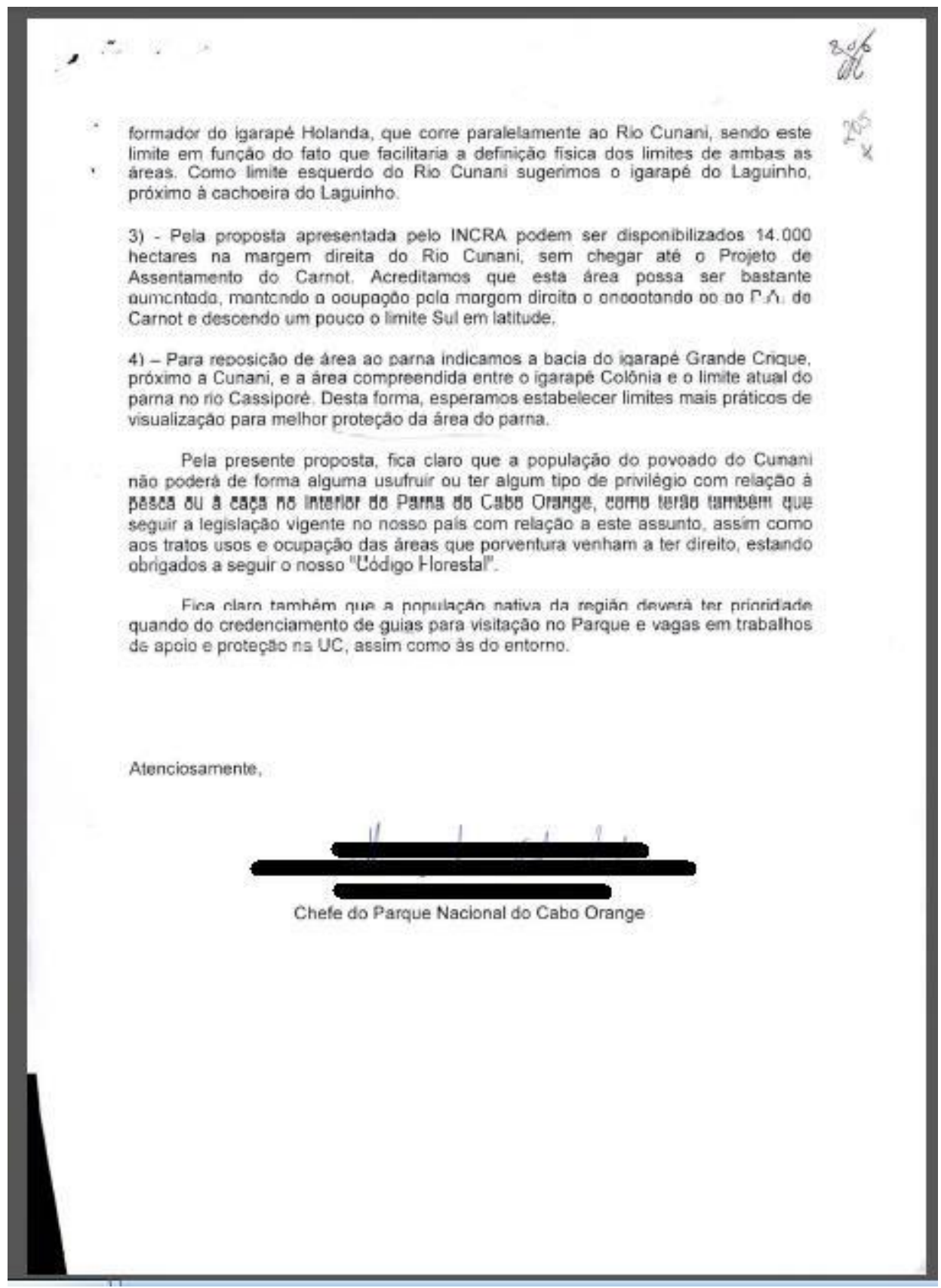

Figura 09: PNCO/IBAMA: Parecer Proposta de Criação de Remanescente de Quilombo. Fonte: Processo Administrativo INCRA/AP. (Folhas 204 e 205). Adaptado pelo autor.

Ao se analisar a proposta emitida pelo IBAMA, chama a atenção a preocupação dos técnicos em solicitar que a demarcação da área quilombola seja analisada por critérios técnicos, levando-se em conta a necessidade de não se desmembrar uma área maior do que a necessária para a subsistência da população remanescente, o que demonstra, por parte da equipe técnica do IBAMA, à época, um total desconhecimento e/ou falta de sensibilidade a respeito do significado técnico, jurídico, geográfico e antropológico da titulação das terras das comunidades 
tradicionais quilombolas. É evidente que o IBAMA reduziu a demanda quilombola aos critérios que são comuns à criação de projetos de assentamento tradicionais da reforma agrária, nos moldes dos que foram implantados até então no Amapá como, por exemplo, o Projeto de Assentamento Carnot, citado no documento, que trata, basicamente, de um projeto de colonização, estabelecido pelo INCRA, na década de 1990. Nesse entendimento proposto pelo IBAMA, a terra é classificada estritamente como meio de produção material e dotada de funcionalidade meramente econômica, desprezando-se, portanto, toda uma importância cultural, imaterial, subjetiva, cuja relevância é intangível para a valorização da identidade, que vincula a comunidade quilombola ao seu território tradicional, além de desprezar todo o ordenamento jurídico que fundamentava a titulação das terras quilombolas à época. Outro ponto que chama a atenção é a preocupação dos técnicos do IBAMA em deixar claro que a comunidade

(...) não poderá usufruir ou ter algum tipo de privilégio com relação à pesca ou à caça no interior do Parna do Cabo Orange, como terão também que seguir a legislação vigente no nosso país em relação a esse assunto, assim como aos tratos e usos e ocupação das áreas que porventura venham a ter direito, estando obrigados a seguir nosso "Código Florestal".

Apesar das evidentes limitações e abusos da proposta enviada pelo IBAMA, entende-se que, no pior dos cenários, tratava-se de uma proposta formal e constituía-se num ponto de partida para a abertura de um canal de negociação e, nesse novo momento, já admitia a negociação, via reparação da área desmembrada do PNCO. Contudo, não há no processo administrativo qualquer registro de resposta do INCRA ou da Comunidade do Cunani referente à proposta do IBAMA, até a publicação do edital de reconhecimento da comunidade, publicado no DOU em 28 de março de 2005, cujo teor disponibilizamos na Figura 10: 


\section{to \\ MINISTÉRIO DO DESENVOLVIMENTO AGRÁRIO \\ INSTITUTO NACIONAL DE COLONIZACCĀO E REFORMA AGRÁRIA - INCRA \\ SUPERINTENDÊNCIA REGIONAL DO AMAPÁ-SR-21/AP}

E D I T A L N N 001/04

O Instituto Nacional de Colonização e Reforma Agrária INCRA, pela sua Superintendente Regional do Amapá, nomeada pela Portaria/INCRA/P/N 1.102 DE $24 / 11 / 2003$, torna público, para conhecimento dos interessados, o presente edital de reconhecimento como área remanescente de comunidade quilombola, da Comunidade do CUNANI, com ärea de 36.162.5832 há (trinta e seis mil, cento e sessenta e dois hectares, cinquuenta e oito ares e trinta e dois centiares), inserida na Gleba Cunani, município de Calçoene, Estado do Amapá, arrecadada sumariamente através da Portaria/INCRA/DF/N $216 / 96$, matriculada em nome da União, sob o n 41 , Livro 2, fls. 42, em 14/04/97 - Cartório de Kegıstros de Imóveis do Municipió đe Calçoene-AP. Referida área a ser reconhecida, limita-se ao Norte com a margem sul do Lago do Tralhoto e Parque Nacional do Cabo Orange; ao Sul com terras de dominio da União, remanescentes da Gleba Cunani; a Leste com a ME do Igarapé Tímbozal e Parque Nacional do cabo Orange e a Oeste com o Parque Nacional do cabo Orange e terras de dominio da União, remanescente da Gileba Cunani.

Os interessados na contestação do presente procedimento o devem fazer no prazo de 90 (noventa) dias á contar da publicação do presente, oferecendo recurso e juntando as provas pertinentes, encaminhando o mesmo a esta Superintendência Regional.

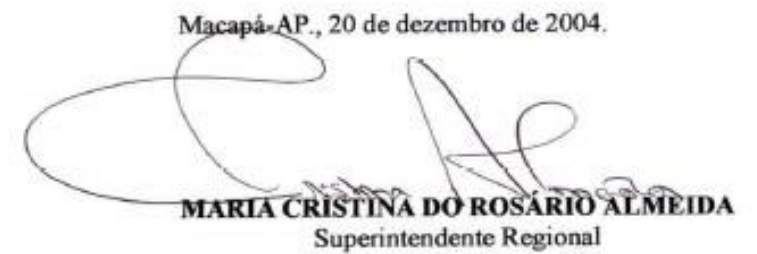

Superintendente Regional

Figura 10: Edital № 001/04: Reconhecimento como área de remanescente de comunidade quilombola da comunidade de Cunani. Fonte: Processo Administrativo, Folha 212.

Nota-se, pela análise do referido Edital, que fora reconhecida a área de 36.162.5832 ha, ou seja, tendo como limite a porção sul do Lago do Tralhoto e excluindo-se a área que continha a jazida de manganês, concessão feita pela Comunidade, em favor da resolução do impasse, em relação ao PNCO.

Dessa forma, a Procuradoria Federal no Amapá recomendou a remessa dos autos para outorga do título. Salienta, porém, a necessidade de formalização da proposta de compensação da área ao PNCO com produção de memorial descritivo e mapa da área a ser objeto de compensação. 
Ocorre que, como visto anteriormente, o processo administrativo de titulação das terras quilombolas da comunidade de Cunani teve início um dia antes da publicação da IN/16 de 2004, sendo este instrumento normativo adotado como referência para os trabalhos. Desta forma, quando o processo foi remetido pela Superintendência Regional do INCRA para apreciação da Superintendência Nacional de Desenvolvimento Agrário (Sede do INCRA, em Brasília) para autorização da emissão da titulação do território quilombola, em agosto de 2005, a IN/16 estava em vigor. Porém, quando o processo administrativo retornou à superintendência (despacho datado de 03 de outubro de 2005) para a sequência do trâmite burocrático, com vistas à titulação da área, a IN/16 havia sido revogada pela IN/20 fazia 14 dias, ou seja, em 19 de setembro de 2005.

Conforme discutido no Capítulo III, a IN/20, dentre outras alterações, passa a exigir a elaboração de um relatório antropológico, como uma etapa do Relatório Técnico de Identificação e Delimitação do perímetro, reivindicado pela comunidade. Dessa forma, o trabalho foi novamente avaliado pela Procuradoria Federal Especializada da Superintendência do Amapá que concluiu:

Apesar de ter sido publicado o Edital em dezembro de 2004, sob a égide da IN no16 de 2004, o mesmo deverá ser republicado, tendo em vista o que preceitua o art. 11 da IN n-20/05, que revogou a IN nำ16/04, pois a publicação do Edital deverá conter o Relatório Técnico de Identificação, o mapa e o memorial descritivo da área estudada (...). (Processo Administrativo INCRA, Folha 221).

Além da necessidade de elaboração do relatório antropológico, o novo parecer da AGU/PFE passou a condicionar seu posicionamento final à conclusão de outros trabalhos, sendo o mais relevante a definição da Superintendência Regional do INCRA em relação à contraproposta de compensação de área feita pelo IBAMA. Motivada pelo fato da comunidade do Cunani estar situada em faixa de fronteira com a Guiana Francesa, há que se destacar também a posição ${ }^{14}$ do Gabinete de Segurança Institucional (GSI) quanto à necessidade de se considerar as exigências da IN/20.

Nesse contexto, uma equipe do INCRA se desloca até a comunidade de

$14 \quad$ OFÍCIO No 283 - GSIPR/SAEI-AP de 27 de outubro de 2005 - Fonte: Processo Administrativo INCRA. Folha 228. 
Cunani, em 02 de novembro de 2005, para submeter à comunidade a proposta de:

(...) que fosse titulada de imediato a área pertencente à União e a outra maior onde está inserida a vila e que está o Parque, que fosse proposto um Termo de Cessão de Uso, enquanto o processo tramitasse na Câmara dos Deputados. (Fonte: Ata de Reunião. Processo Administrativo INCRA. Folha 229).

Essa proposta de titulação parcial foi tomada com desconfiança pela comunidade, afinal, a área da Vila estava totalmente incluída no interior do PNCO e o Termo de Cessão de Uso não representaria uma solução definitiva de sua situação frente ao PNCO e, portanto, às restrições que, por ventura, poderiam the ser impostas. Havia um temor que os quilombolas de Cunani passassem a sofrer as mesmas restrições impostas pelo PNCO aos moradores da vila de Taperebá, comunidade tradicional de pescadores localizada na foz do rio Cassiporé, também situada nos limites do parque. Todavia, relata o documento que as lideranças se comprometeram a se reunir com a comunidade, para decidir sobre a proposta do INCRA, ficando de mandar um documento informando ao INCRA sobre a decisão da comunidade. Contudo, apesar de não identificamos tal documento de resposta nos autos do processo, essa proposta não prosperou.

A partir daí, nota-se um hiato temporal no processo, que é retomado na data de 31 de outubro de 2006, quando o INCRA estabelece os trâmites burocráticos para uma parceria com uma antropóloga e professora da Universidade Federal do Pará para realizar uma pesquisa de campo para subsidiar o Relatório sócio-histórico da comunidade de Cunani. Tal deslocamento foi realizado entre os dias 07 e 12 de novembro de 2006 e gerou apenas um simples relatório de viagem com 05 páginas, muito aquém do produto estabelecido, precariamente naquilo, que foi denominado como parceria e do que exigido pela IN/20 de 2005.

Mais um hiato é identificado no processo até que a Coordenação Geral de Regularização de Territórios Quilombolas (DFQ/INCRA) enviou o MEMO/INCRA/DFQ/№506/2007, solicitando com a máxima brevidade, o processo referente ao território de Cunani, a fim de que possamos realizar estudos e procedimentos quanto à questão de sobreposição de áreas sobre a do IBAMA. O referido memorando fora datado em 01 de novembro de 2007. O processo fora 
protocolado na sede da autarquia em Brasília em 04 de janeiro de 2008 e retornou para a capital amapaense em 14 de março de 2008, com o Despacho da Coordenação Geral de Regularização de Territórios Quilombolas (DFQ/INCRA). Esse Despacho faz a primeira menção no âmbito do processo administrativo à Câmara de Conciliação e Arbitragem, solicitando que

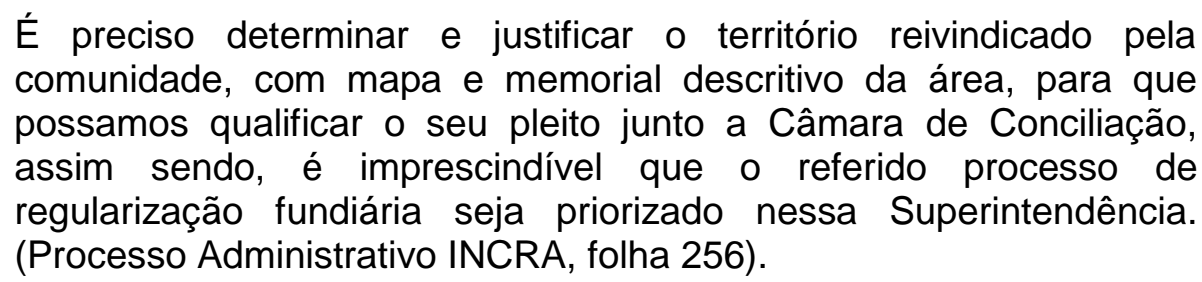

Entretanto, convém destacar que a proposta de incluir as questões, que envolviam as demandas quilombolas e as unidades de conservação geridas pelo IBAMA/ICMBio no âmbito da Câmara de Conciliação e Arbitragem (CCAF), foi uma iniciativa do ICMBio, em ofício encaminhado ao Advogado-Geral da União, em 19 de dezembro de 2007, conforme pode ser observado na cópia abaixo, que consta do processo administrativo INCRA: 


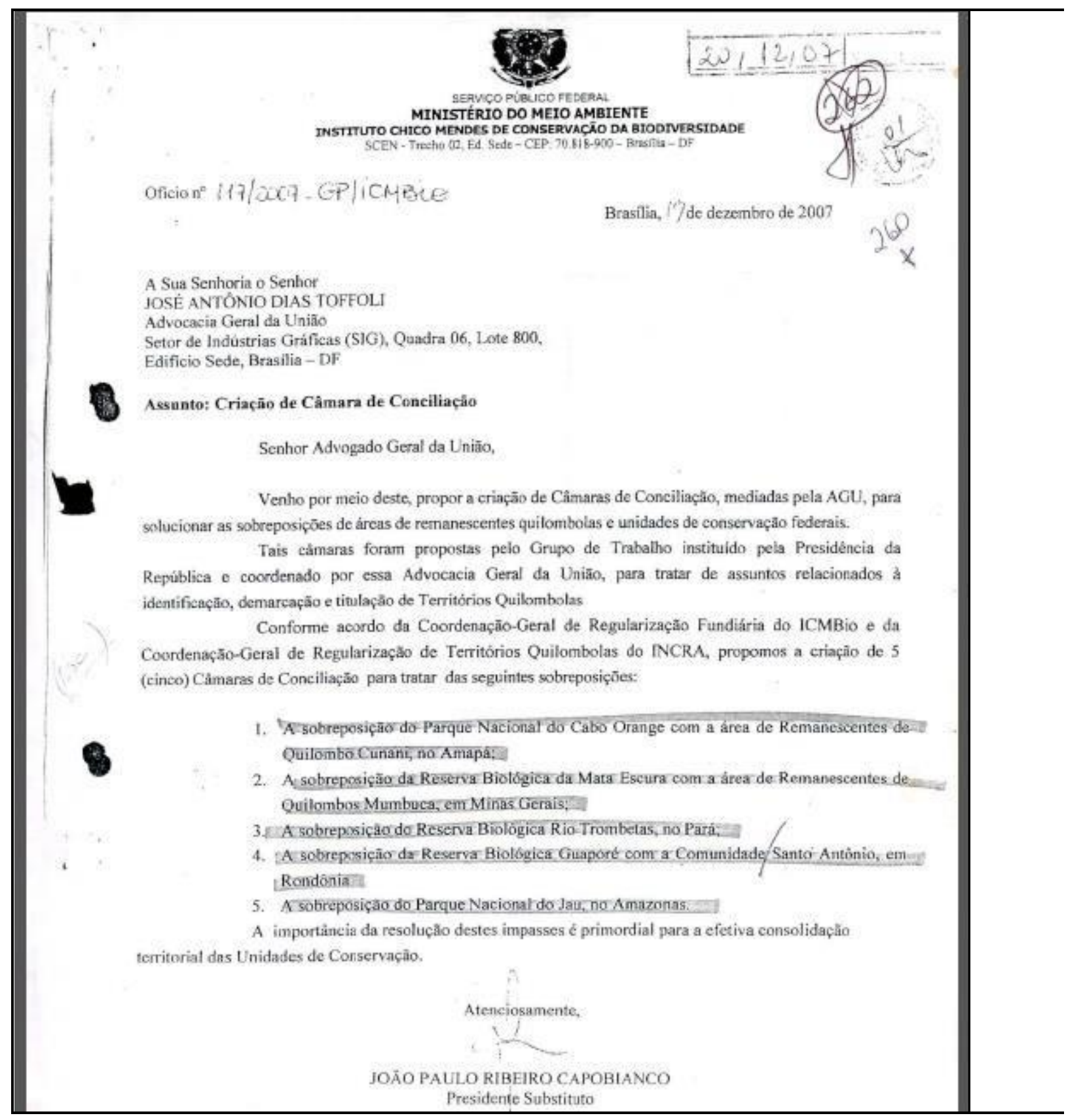

Figura 11: ICMBio: Criação da Câmara de Conciliação. Fonte: Processo Administrativo INCRA, folha 260.

Assim, iniciou-se o mais longo hiato verificado no processo de regularização do território quilombola do Cunani, que só é encerrado, quando uma equipe técnica do INCRA visita a comunidade em 06 de fevereiro de 2013, para lhes apresentar 0 Relatório Antropológico realizado pela Fundação Marco Zero (FMZ), ligada à Universidade Federal do Amapá (UNIFAP), com recursos oriundos da Agência de 
Desenvolvimento do Amapá (ADAP). O Relatório Antropológico da Comunidade do Cunani é datado de março de 2012 e fora protocolado no INCRA em junho de 2012.

A conclusão e remessa dessa peça técnica ao INCRA abriu a possibilidade de se elaborar as demais peças técnicas, que compõem o RTID, tais como o levantamento fundiário, cadastro das famílias quilombolas e levantamento de sobreposições, que culminou com o Parecer Técnico Conclusivo que definiu pela aprovação dos referidos trabalhos e pelo prosseguimento do trâmite processual visando o reconhecimento e a titulação do referido Território Quilombola.

Este documento foi assinado em 30 de janeiro de 2015. No dia 10 de fevereiro de 2015, o Conselho de Decisão Regional da Superintendência do INCRA no Amapá aprovou por unanimidade os trabalhos do RTID. A Figura 12 refere-se ao Mapa Fundiário do Território Quilombola do Cunani, que consta no referido Processo Administrativo INCRA: 


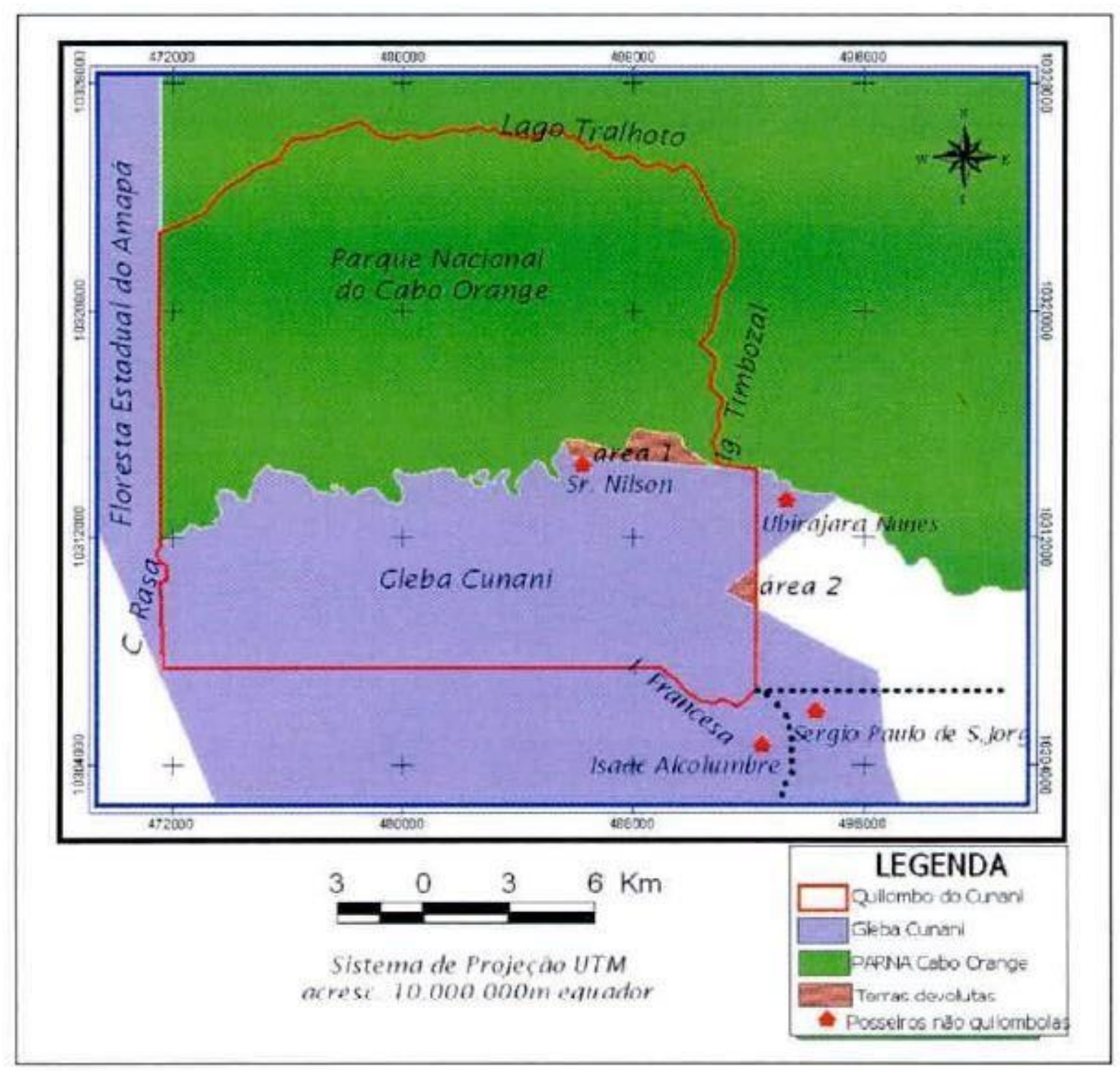

Figura 12: Quadro Fundiário do Território Quilombola do Cunani: Sobreposição com Glebas Cunani (GEA), PARNA Cabo Orange(ICMBio) e posseiros.

Fonte: Processo Administrativo INCRA.

No entanto, por força do Memorando nำ115/2015/DFQ/INCRA de 19 de junho de 2015, a superintendência regional foi informada de que, no âmbito da CCAF, fora acordada que a publicação do RTID ocorreria após a conciliação dos interesses de Estado e definição da área a ser regularizada em benefício da comunidade (Processo Administrativo INCRA, folha 400). Esse expediente poderia representar a perda de todas as peças técnicas que haviam sido produzidas e aprovadas pela superintendência regional, uma vez que uma simples alteração de limites, por menor que fosse, poderia abrigar a novas incursões a campo para atualização da planta, memorial descritivo, cadastro de ocupantes etc. o que, inevitavelmente, traria uma 
série de constrangimentos e procrastinações burocráticas ao andamento do processo administrativo.

Para que se compreenda essa situação, faz-se necessário recuperar, mesmo que resumidamente, os trâmites que a demanda da Comunidade de Cunani seguiu no âmbito da CCAF, para, em seguida, retornarmos ao processo administrativo INCRA.

\section{5 - Os procedimentos para solução da controvérsia: A peregrinação burocrática na CCAF}

Como mencionado anteriormente, com vistas à criação de condições para solucionar o conflito fundiário, que abarca a comunidade quilombola do Cunani, bem como de outras comunidades com unidades de conservação sobrepostas em seu território tradicional, foi instituída na Câmara de Conciliação e Arbitragem Federal (CCAF), o Processo no 00400.007270/2007/13 - Comunidades Quilombolas/Unidades de Conservação, com o objetivo de solucionar a controvérsia entre o ICMBio e o INCRA, cuja mediação caberia à Advocacia Geral da União (AGU). Chacpe $(2014$, p. 106) relata que

(...) aos 19 dias do mês de dezembro de 2007, o Presidente do ICMBio expediu Ofício n. 117/2007 - GP/ICMBio ao Senhor Advogado-Geral da União para propor a criação de Câmaras de Conciliação para solucionar as sobreposições de territórios quilombolas e unidades de conservação federais. Àquela época, foi proposta pela Coordenação-Geral de Regularização Fundiária do ICMBio e pela Coordenação-Geral de Regularização de Territórios Quilombolas do INCRA a criação de 5 (cinco) Câmaras de Conciliação.

Cada uma dessas Câmaras dedicou-se à conciliação e/ou arbitragem que abrange a reivindicação de uma comunidade quilombola-INCRA-FCP de um lado e, de outro, o IBAMA (posteriormente o ICMBio), como representante dos interesses da política de conservação e proteção ambiental. Dessa forma, foram criadas as 
Câmaras para solução dos seguintes impasses:

- Reserva Biológica do Guaporé e Território Quilombola Santo Antônio do Guaporé, em Rondônia;

- Reserva Biológica Mata Escura e Território Quilombola Mumbuca, em Minas Gerais;

- Parques Nacionais Aparados da Serra e Serra Geral e Território Quilombola São Roque, em Santa Cataria e Rio Grande do Sul;

- Parque Nacional do Jaú e Território Quilombola Tambor, no Amazonas;

- Parque Nacional do Cabo Orange e Território Quilombola do Cunani, no Amapá;

- Reserva Biológica do Rio Trombetas e Território Quilombola Rio Trombetas, no Pará.

O servidor do INCRA do Amapá, Engenheiro Agrônomo Marcos Quadros, foi designado para representar a autarquia no caso Cunani versus ICMBio, em Brasília. Posteriormente, o processo geral foi desmembrado em processos individuais, situação em que o processo que envolvia a comunidade do Cunani passou a receber o número 00400.010204-2010-26. Via correio eletrônico, o servidor nos relatou que: 
Em 28/10/2008, ocorreu reunião na Consultoria-Geral, edifício sede da Advocacia-Geral da União (Termo de Reunião n. CCAF-CGUAGU-SRG 088/2008), oportunidade em que o INCRA informou sobre a ausência de elaboração do relatório antropológico e a intenção de que seja realizado em conjunto com representantes da autarquia ambiental, a fim de já serem construídas paulatinamente soluções que atendam ao interesse social e ambiental. Quanto ao INCRA, foi fixado prazo para informar o início dos trabalhos de campo para elaboração do RTID, de modo que à CCAF caberia repassar a informação para os demais, notadamente à área ambiental, para que pudesse indicar técnicos para acompanhamento dos trabalhos. Esta foi a única reunião de conciliação relacionada ao conflito socioambiental específico da comunidade Cunani sobreposta ao Parque Nacional do Cabo Orange. (Informação verbal ${ }^{15}$ )

A Figura 13 é o resultado de uma consulta ao sítio eletrônico da Advocacia Geral da União (AGU) e demonstra todos os trâmites adotados no âmbito desse processo no âmbito da CCAF, assim com as datas em que tais movimentações aconteceram. 


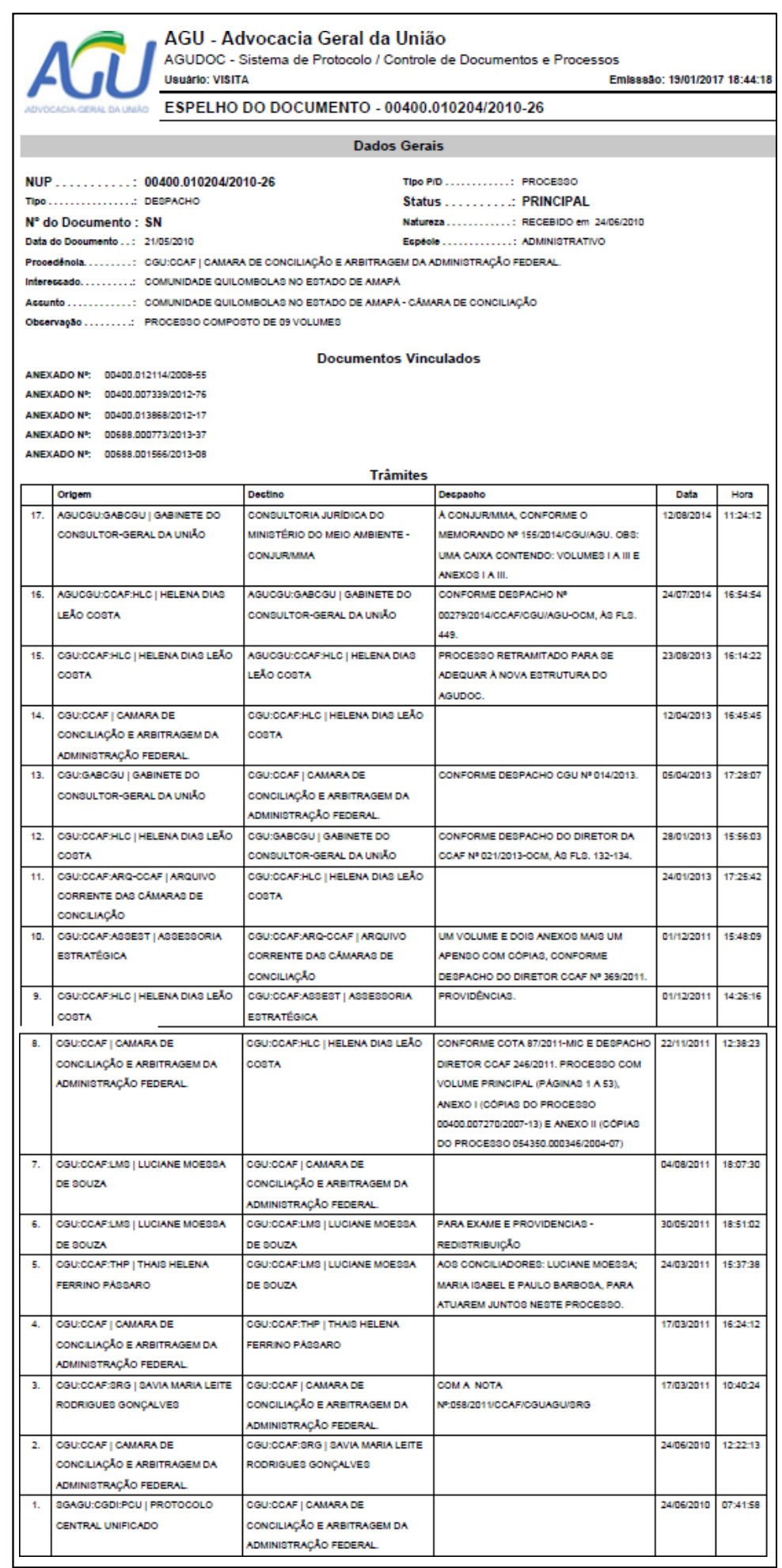

Figura 13: Tramitação do Processo Cunani/INCRA versus ICMBio no CCAF/AGU Fonte: AGU. Adaptado pelo autor.

Pelo exposto na Figura 13, nota-se uma extensa movimentação processual, que contou com várias notas, exames, despachos e memorandos. O início da peregrinação burocrática em 24 de junho de 2010 (processo individual, 
desmembrado do que envolvia as outras 05 controvérsias). A última movimentação se deu em 12 de agosto de 2014, saindo do Gabinete do Consultor Geral da União com destino à Consultoria Geral do Ministério do Meio Ambiente (CONJUR/MMA) sem, contudo, apresentar uma conciliação ou arbitragem como produto ou resposta às autarquias envolvidas e muito menos à comunidade quilombola interessada.

\section{6 - Retomando a análise do processo administrativo INCRA}

A morosidade e ineficiência da Administração Pública, em se praticar encaminhamentos para solução da controvérsia institucional que impedia até mesmo a publicação do RTID pela superintendência regional, motivou mais um ator a entrar em cena: o Ministério Público Federal - MPF/AP, no âmbito da 6a Câmara de Acompanhamento e Revisão.

Dos documentos que nos foi permitido acesso, especialmente a partir de pesquisa ao sítio eletrônico do MPF/AP <www.mpf.mp.br>, a movimentação mais antiga que trata da titulação das terras que abrangem a Comunidade de Cunani refere-se à Recomendação 01 de 24 de outubro de 2012, parte integrante do Inquérito Civil Público № 1.00.000.000991/2010-55. A Recomendação 01 de 2012 considera que

(...) há inúmeras controvérsias entre órgãos e entidades públicas federais, envolvendo a consecução de políticas públicas para a realização de direitos fundamentais, muitas delas relativas a questões indígenas e de populações tradicionais, perdurando por tempo muito além do razoável e outras que foram retiradas da Câmara de Conciliação e Arbitragem da Administração Federal (CCAF), todas sem conciliação ou arbitragem, a configurar grave omissão da União.

Após considerar que o prazo razoável para a duração de um processo é direito fundamental que se refere a processos judiciais e administrativos, recomenda ao Consultor-Geral da União promova a conciliação ou, quando não cabível esta, a arbitragem das controvérsias (...) em 180 dias. 
A atuação do MPF/AP no que se refere ao processo de regularização do território quilombola do Cunani remete também à Recomendação № 26 de 2013, em que trata da controvérsia administrativa entre o INCRA e o ICMBio em razão da sobreposição geográfica da área de interesse da Comunidade Quilombola de Cunani com a área do Parque Nacional do Cabo Orange. Relata o MPF/AP que

- No âmbito da CCAF, em nenhuma reunião, foi ouvida a comunidade remanescente de quilombo do Cunani, parte diretamente interessada na controvérsia;

- Em audiência pública realizada em 26 de novembro de 2013, a comunidade demonstrou sua insatisfação na morosidade e total falta de informações sobre o processo instaurado no INCRA;

- A comunidade solicitou o direito de ser ouvida nas reuniões perante ao CCAF, em reunião ocorrida na sede da Procuradoria da República no Amapá, em 26 de novembro de 2013.

Neste ínterim, o MPF/AP recomendou à CCAF que convide a Associação dos Moradores Remanescentes de Quilombolas de Cunani para participar de todas as reuniões necessárias à resolução da presente controvérsia, o que jamais foi atendido.

Contudo, a atuação do MPF parece ter gerado consequências fundamentais para o prosseguimento do processo. Em primeiro lugar, devido ao fato de que 0 Tribunal Regional Federal da Primeira Região - Subseção Judiciária de Oiapoque ter concedido, em parte, a liminar pleiteada, para determinar a participação da comunidade do Cunani nos procedimentos de resolução do conflito; que o INCRA e - ICMBio se abstenham de adotar qualquer medida ou solução que importe em diminuição do território identificado no RTID ou em sua remoção/realocação; que o ICMBio estabelecesse em 60 dias, normas e ações específicas destinadas a compatibilizar a presença da Comunidade do Cunani com os objetivos da unidade, sem prejuízo do modo de vida, assegurando a participação da comunidade e do 
MPF na elaboração das referidas normas e ações ${ }^{16}$.

Tendo em vista a necessidade de se cumprir a decisão judicial, os autos do processo foram então encaminhados para a DFQ/INCRA em Brasília, para que fosse possível subsidiar as tratativas na CCAF.

Entretanto, em 21 de dezembro de 2015, foi expedido pela Procuradora Federal Conciliadora e pelo Advogado da União Conciliador a Nota n00120/2015/CCAF/CGU/AGU, relativo à decisão da CCAF pelo encerramento do procedimento conciliatório, alegando inércia e falta de comprometimento institucional dos envolvidos (INCRA e ICMBio), e que não foi possível alcançar um acordo na CCAF, tampouco existe perspectiva de alcançá-lo com a utilização de métodos autocompositivos ${ }^{17}$. Terminou assim a passagem do pleito da comunidade quilombola do Cunani pela burocracia administrativa da CCAF, sem nenhuma conciliação entre INCRA e ICMBio, sem a comunidade ter o direito de participar ativamente do processo e, o que é mais intrigante: sem a CCAF ter concluído o procedimento com uma arbitragem.

Entretanto, é imperativo ressaltar que estava sendo discutida uma proposta entre ICMBio e INCRA que previa a desafetação de uma área sobreposta ao Parque bem menor do que aquela reivindicada pela comunidade, conforme ilustra o anexo que sintetiza as propostas aceitas pelo INCRA para a conciliação, a saber:

\footnotetext{
16 Processo n ${ }^{\circ}$ 0000005-38.2015.4.013102 - Vara Única de Oiapoque, de 18 de maio de 2015. Fonte: Processo Administrativo INCRA, folha 510.

Processo Administrativo INCRA, folha 528.
} 


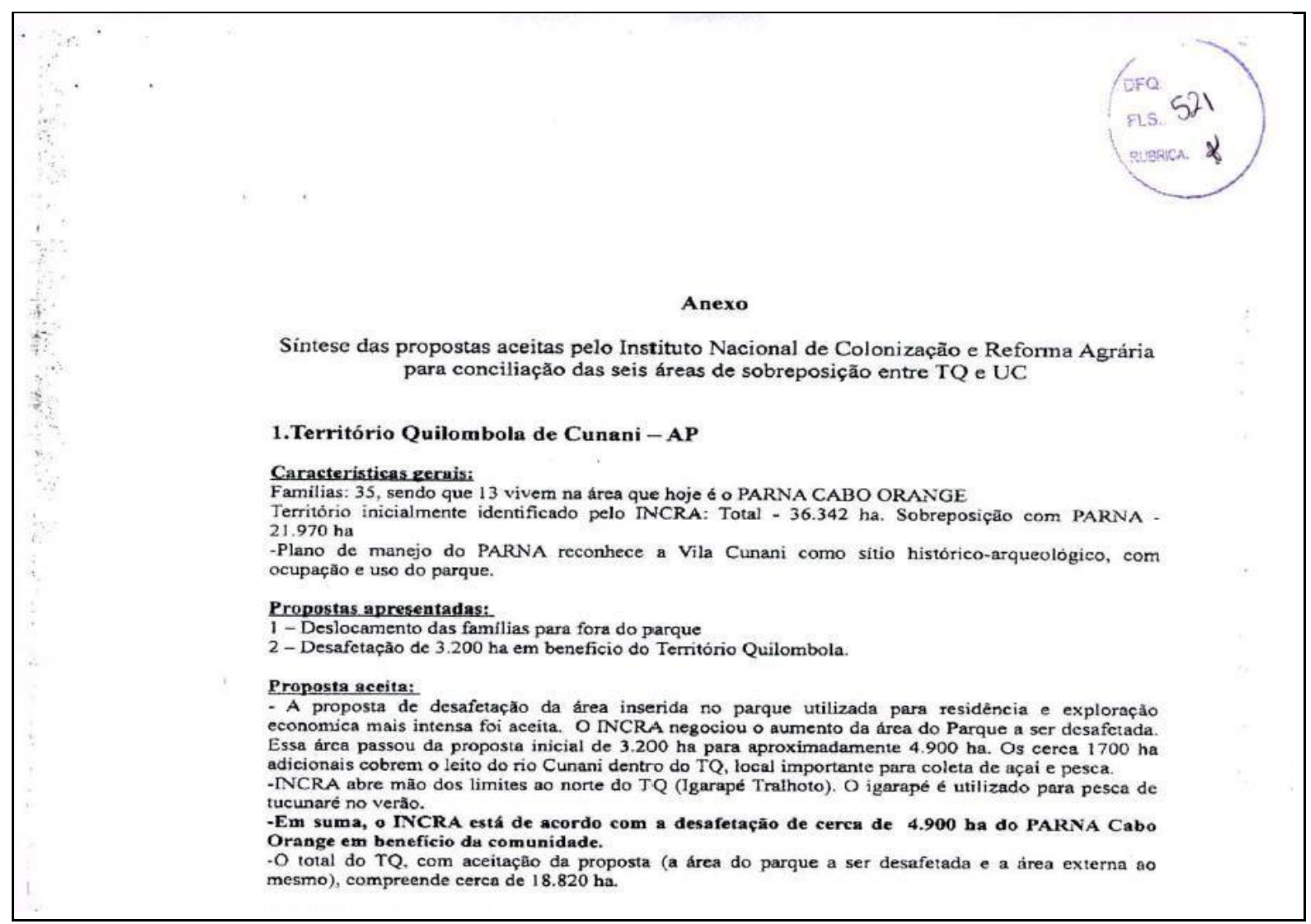

Figura 14: Proposta aceita pelo INCRA no âmbito da CCAF. Fonte: Processo administrativo, folha 521.

A mesma Nota reforça essa informação, apontando no Memorando no 316/2014/CONJUR/MMA o seguinte teor:

Houve acordo entre o ICMBio e o INCRA no sentido da revisão dos limites do Parque Nacional, para dele excluir 4.900 hectares, e destiná-los à regularização do território quilombola. O texto do acordo elaborado pelo ICMBio foi modificado pelo INCRA sem a concordância do primeiro. A matéria não chegou a ser discutida formalmente na Câmara de Conciliação porque o INCRA preferiu aguardar que se completasse um lote de seis situações. Havendo interesse do INCRA em concluir a tramitação desta situação separadamente das demais, nada obsta que seja marcada reunião na Câmara de Conciliação para compatibilização do texto no acordo.

Como não houve prosseguimento dessas tratativas devido, primeiro, à injustificada decisão de só tratar as situações em lote (o que nos parece descabido, afinal a situação envolvia pleitos diferentes e independentes entre si), bem como pelo ao encerramento em decisão unilateral do procedimento conciliatório 
pela CCAF, o ICMBio e INCRA expediram a Portaria Conjunta/nํ 01 de 29 de janeiro de 2016, que

(...) cria o Grupo de Trabalho Interinstitucional - GTI com escopo de elaborar propostas de normativos conjuntos e de procedimentos visando ações integradas e ao aprimoramento do intercâmbio de informações em temas de interesse comum das autarquias, em especial: a) elaborar fluxo de procedimentos e aprimorar 0 intercâmbio de informações no que tange às interfaces territoriais e a solução dos casos de sobreposição de interesses; (...).

Dentre os principais avanços do GTI em relação a CCAF, nota-se a possibilidade de convite a representantes de organizações das sociedade civil, tal como as lideranças quilombolas, para contribuir para a execução dos trabalhos, algo que não era possível no âmbito da CCAF/AGU e que se alinha ao que é disposto na Convenção 169 da OIT.

Em todo caso, a iniciativa do GTI (posteriormente renovado pela Portaria Conjunta no 03 de 05 de outubro de 2016), gerou um avanço estrategicamente importante para o pleito da comunidade de Cunani, que foi o consenso entre as autarquias em promover a publicação do RTID, conforme previsto pela IN/57 de 2009, uma vez que a publicação realizada em 28 de março de 2005 não atendeu à IN/20 de 2005, conforme discutido anteriormente.

Dessa forma, deram-se os encaminhamentos no âmbito do INCRA/AP, tendo o RTID sido aprovado pelo Conselho de Decisão Regional (CDR) e publicado no DOU em 04 de novembro de 2016, encontrando-se, no momento de redação deste texto, na fase de contestações e manifestações dos proprietários/ocupantes identificados na área reivindicada, bem como dos órgãos e instituições diretamente interessadas na questão, conforme normatizado pela IN/INCRA 57 de 2009.

Todavia, há que se ressaltar que este consenso entre as autarquias se deu apenas em relação à publicação do RTID, como medida que visa garantir à comunidade o acesso à área não sobreposta ao PNCO, inclusive àquelas que foram apoderadas por ocupantes não-quilombolas. Isso significa que ainda não se vislumbra uma solução para a controvérsia, conforme destaca o OFICIO SEI nº51/2017 - CR4/ICMBio/ICMBio, em que a Coordenação Regional do ICMBio - 4ª Região/Belém-Pará marcou posicionamento formal da instituição em consequência 
da publicação do RTID pelo INCRA, deixando claro que

(...) Para o caso da comunidade quilombola do Cunani e PNCO, enquanto não há finalização do processo de conciliação entre as duas autarquias, o GTI definiu, num primeiro momento, pela publicação do Edital do RTID no DOU em 01/11/2016. Ao mencionar e reconhecer „a sobreposição entre o Território Quilombola Cunani e Parque Nacional do Cabo Orange", a intenção do referido Edital foi possibilitar ao INCRA realizar a regularização fundiária da parte do território quilombola não sobreposta ao PNCO, garantindo assim, de forma mais imediata, o acesso à terra de uma importante parcela daquele território quilombola. Em relação à área sobreposta, o edital faz menção explícita que as duas autarquias „instituíram Grupo de Trabalho Interinstitucional - GTI por meio da Portaria Conjunta nํ01, de 29 de janeiro de 2016, para elaboração da proposta de conciliação dos interesses comuns das autarquias quanto à área a ser regularizada". Nesse contexto, Senhor Superintendente, ao agradecer o envio do RTID relativo à comunidade quilombola do Cunani, entendemos que o caso de sobreposição aqui retratado já conta com as iniciativas institucionais e encaminhamentos apropriados com vistas a possibilitar, em curto-médio prazo, a finalização do processo de conciliação envolvendo a definição do referido território quilombola. (Fonte: Processo Administrativo INCRA, folhas 573-4).

\section{7 - A voz da comunidade: avaliação da atuação do poder público frente ao} reconhecimento de seus direitos étnicos territoriais.

No decorrer da visita técnica, que este pesquisador realizou até a cidade de Calçoene e, posteriormente à Vila de Cunani, no chuvoso dia 24 de março de 2017, foi possível ouvir as avaliações dos cunanienses, a respeito da questão, a que foram levados a travar contra o Estado brasileiro, pelo justo direito de titulação das terras, que tradicionalmente ocupam, há várias gerações.

Os principais pontos que nortearam as entrevistas versaram a respeito:

- Da origem do impasse entre Comunidade Cunani e PNCO;

- Como esse impasse tem impactado a vida da comunidade;

- Qual a avaliação que a comunidade faz a respeito da atuação do poder 
público em relação à questão;

- Qual a importância da titulação das terras para a comunidade.

Inicialmente, notou-se claramente na fala dos entrevistados um grande ressentimento por terem sido ignorados, quando da criação e implantação do PNCO, bem como da forma com que a informação de que a Vila de Cunani e seu território tradicional estariam sobrepostas aos limites do PNCO "chegou"18" à comunidade.

A noticia da chegada do Parque veio depois de uns 5 anos... Vieram e colocaram uma placa na casinha do santo. O pessoal se assustou, porque eram muitos anos morando aqui. (Sr. Amâncio, Com. Cunani. Informação verbal)

A demanda surgiu através da deputada Cristina Almeida (à época Superintendente Regional do INCRA no Amapá) que surgiu a ideia do quilombo, que foi documentada na Fundação Palmares. Depois de dois anos descobriu que era Parque. Até o escritório deles é dentro da comunidade por que os pescadores não gostam de receber o lbama (na época era Ibama). Depois passaram a querer tirar nós de lá e começou o conflito, porque eles não aceitavam nossa proposta e nós não aceitamos a deles. (Sr. Domingos, Com. Cunani. Informação verbal).

Por outro lado, são várias as recordações dos moradores que versam sobre a vida antes "da chegada" do parque. Sr. Amâncio, por exemplo, recorda da efervescência da vila onde nasceu, nas redondezas de Cunani.

Onde eu nasci, na vila Tomásia, tinha uma vila muito grande. $O$ terreno era da mãe do meu pai. Tinha muita casa. Essa beira de rio era tudo cheia de casa. Na época que criaram o Parque ela ainda existia. Ficava do outro lado do rio (Cunani). (Sr. Amâncio, Com. Cunani. Informação verbal)

Os entrevistados são unânimes em associar a "chegada" do PNCO como um marco para a precariedade com que as famílias da comunidade foram e estão sendo acometidas desde então. Dentre os motivos que elencam como os principais, o

\footnotetext{
18 A expressão "chegada do parque" é comumente utilizada pelos cunanienses para se referir à criação e implantação do PNCO em seu território, razão pela qual esse pesquisador resolveu utilizá-la sempre que possível para expressar com a maior fidelidade possível a interpretação e sentimento da comunidade em relação à questão.
} 
primeiro a ser destacado é o veto do ICMBio à implantação na Vila da rede de fornecimento de energia elétrica:

Já era pra termos energia aqui. Acho que se não tem até hoje e não evolui é por causa deles (ICMBio). (Sr.Domingos, Com. Cunani. Informação verbal).

Nunca tivemos um conflito de estar brigando com o ICMBio. Só esse negócio da energia. Eles dizem que não é eles, mas é. (Sr. Amâncio, Com. Cunani. Informação verbal).

Outro motivo identificado é a proibição imposta pelo ICMBio de os cunanienses construírem novas moradias na área sobreposta ao PNCO, o que se revela um ponto de tensão importante da comunidade com o ICMBio. O Sr. Amâncio assevera que:

(...) tinha um acerto entre a comunidade e o IBAMA que não podia fazer mais casa, só renovar as que já tinham. Eles botaram essa humilhação pra nós. (Sr. Amâncio, Com. Cunani. Informação verbal)

$\mathrm{Na}$ ótica dos cunanienses ouvidos, a proibição por parte do ICMBio, de se construir novas casas ou um galinheiro que fosse está diretamente vinculada a outro motivo da precariedade, com que foram obrigados a lidar, que é a desativação da escola da Vila de Cunani. Sobre esse ponto, argumentam que se não há permissão de se construir novas residências, não havia possibilidade de permanência daquelas novas famílias que iam se formando ou daquelas que se interessavam em retornar à Vila de Cunani, especialmente aquelas famílias com crianças em idade escolar. Por outro lado, quando as crianças que, por ventura, já moravam na Vila concluíam o ensino básico eram obrigadas a procurar outro estabelecimento de ensino na zona urbana de Calçoene, para assim continuarem os estudos. Porque estas famílias eram obrigadas a se mudarem para a zona urbana, levavam consigo também as crianças mais novas que, mesmo tendo condições de continuar estudando na escola da vila, não o podiam, pois, assim, a família seria dividida entre aqueles que iriam para Calçoene e aqueles que continuariam em Cunani. Essa situação ocasionou, portanto, um ciclo vicioso perverso para a comunidade, que desencadeou um êxodo rural em direção a Calçoene. 
Hoje nós temos umas 10 casas que ficam direto. Mas todo final de semana o caminhão vem de Calçoene pra cá. Vem traz o óleo e volta domingo de tarde. A maioria tem que estudar e vai embora depois de trabalhar. (...) Precisa funcionar a escola. A escola fechou e as famílias têm que morar em Calçoene e só volta pra Cunani nos fins de semana. Sai sexta-feira meio-dia, trabalha no açaizal e farinha e no domingo a tarde volta pra Calçoene. (Sr. Amâncio, Com. Cunani. Informação verbal)

No que se refere à forma com que os cunanienses, que foram ouvidos, avaliam a atuação do poder público na gestão da questão que os envolve, foi solicitado que, num primeiro momento, avaliassem separadamente o INCRA e o ICMBio. Para a surpresa confessa deste pesquisador, as respostas foram as seguintes:

(...) Nota sete para o INCRA. (...) Nas várias reuniões que participamos eu nunca vi o INCRA chegar com nós e pedir pra tratar do assunto. Ele vai, não se opõe a ir, mas sempre como convidado. Como iniciativa dele, eu nunca vi o INCRA atuar. (...). Foi trocado o Dr. Thiago. Esse novo procurador chegou com um mês e já foi na comunidade. E o INCRA não. Se dependesse do INCRA... (Sr. Domingos, Com. Cunani. Informação verbal).

A nota que dou ao ICMBio é oito, pois hoje eu acredito que estamos chegando a um acordo, pela maneira que estamos nos entendendo, com acordo favorável à comunidade. Quanto a forma com que tratam a comunidade eu dou nota dez. No passado eu daria um. (Sr. Amâncio, Com. Cunani. Informação verbal)

Como o INCRA é o órgão que representa e defende os interesses da comunidade na esfera judicial e, juntamente com a AGU/PFE e FCP, esperava-se que a resposta natural a esse questionamento fosse o inverso. Porém, a presença incipiente do órgão fundiário, junto à comunidade e à sensação de descaso identificada no INCRA pela comunidade, são elementos que nos ajudam a compreender essa situação. Por outro lado, fica evidente que o relacionamento da comunidade com os gestores do PNCO tem melhorado muito, com o passar do tempo, a ponto de terem classificado esse relacionamento no passado com a nota um e, atualmente, como "nota dez". Em outra passagem que sintetiza esse histórico de relação entre comunidade e gestão do PNCO, o Sr. Domingos pondera que 
Quando a gerência era com o $\mathrm{M}$, que foi uma pessoa que nos ajudou muito. Nós queríamos ficar com o lago. Ele veio lá do Oiapoque, chegou com a gente, ajeitou. Mas depois mudou pro $\mathrm{R}$, que era contra mesmo. Hoje não. Já tivemos várias reuniões em Macapá. Eles pensavam uma coisa e hoje é outra. (Sr. Domingos, Com. Cunani. Informação verbal).

Está clara na fala dos moradores da comunidade de que a gerência do parque, com o passar do tempo, deixou de identificá-los como uma ameaça, e compreenderam que seu modo de vida não representaria um impacto significativo, para os objetivos do ICMBio na área.

Os entrevistados, também, foram instados a avaliar a atuação dos demais órgãos da administração pública federal, como Polícia Federal, Justiça Federal e da administração estadual, como a Polícia Militar. Todas estas instituições foram avaliadas, satisfatoriamente, pela comunidade. Porém, merece destaque a forma com que se referem ao MPF/AP:

Nas reuniões da CCAF o ICMBio ia, mas nós não éramos nem avisados. Então eu acho que não foi uma decisão acertada, pois nós só ficamos sabendo pelo MPF e começamos a entender como funcionavam as coisas. Era só entre INCRA e ICMBio. Todo o xís da questão estava lá e nós não participávamos. Se não fosse o Dr. Thiago, até hoje... Ele fez umas duas reuniões, trouxe juiz e ICMBio pra dentro da comunidade. Mas quando um cara desses começa a trabalhar, a grilagem de terras... Periga um cara desses a morrer. (Sr. Amâncio e Sra. Rosineia, Com. Cunani. Informação verbal)

Se o processo andou é por causa do Dr. Thiago do MPF, mas hoje para que a coisa não andasse, eles não têm mais nenhum argumento. Nós sentimos que eles não têm mais argumento pra dificultar nossa questão. Estamos mesmo só aguardando nossa titulação. (Sr. Domingos, Com. Cunani. Informação verbal).

Por fim, os entrevistados foram convidados a relatar quais as perspectivas que nutrem em relação à titulação de suas terras, expondo os benefícios que esperam usufruir a partir desse reconhecimento:

Uma vez regularizando as famílias que tinham abandonado o terreno vão voltando. Agora que autorizou a fazer casa os filhos já estão voltando de novo. Já tem gente fazendo manejo do açaí, do cacau. Daqui a dois anos vai ter produção pra exportar. As pessoas vão sair 
da cidade pra voltar para lá. A intenção é voltar para me aposentar lá e ficar sossegado. (Sr. Eronildo, Com. Cunani. Informação verbal)

Eu acho que se sair o título vai mudar muita coisa, porque quando quiser fazer alguma coisa na comunidade não vai mais ter que passar pelo IBAMA. Hoje em dia, se eles não concordarem... (...)

É evidente, na fala dos cunanienses, que a condição de quilombolas foi decisiva, para que pudessem permanecer em seu território tradicional, após a "chegada do parque".

A questão quilombola foi uma saída para resolver o nosso problema. (Sr. Domingos, Com. Cunani. Informação verbal).

A comunidade Taperebá acabou. Parece que tem só dois ou três moradores. Se nós fosse atrás deles já tínhamos saído daqui também. Aquela comunidade que tinha bonita lá acabou. Comunidade de pescadores, né? (Sr. Amâncio, Com. Cunani. Informação verbal)

Com base nesses depoimentos, fica evidenciado que, apesar de restringidos em alguns de seus direitos mais elementares, como acesso à energia elétrica, comunicação, moradia e educação, os cunanienses não abriram mão de sua identidade territorial e mantiveram, a duras penas, o vínculo com a terra tradicionalmente ocupada e encararam e ainda encaram a titulação de suas terras como um direito irredutível que deve ser reconhecido pela União, o que nos faz corroborar as palavras de Giacomini (2009, p.05): 
Em certos ecossistemas, como os de floresta, essas comunidades tradicionais tornaram-se extrativistas. Habitantes das margens de rios tornaram-se ribeirinhos e pescadores, além de agricultores, no interior das matas, à montante das cachoeiras e nas serras, lugares que serviram de abrigo e esconderijos. As simbologias e representações sobre a natureza formuladas pelos quilombolas originaram a base da identidade homem-meio em que vivem. A memória, a terra e a etnia lhes permitiram um vinculo duradouro entre si e com o lugar. Resistir e permanecer nessas terras após vários séculos representa uma luta contra a sociedade vigente, uma vitória histórica. Num sistema socioeconômico-político e territorialmente excludente, a luta pela terra efetuada pelos quilombolas é, de um lado, uma luta pela reforma agrária e de outro, uma tentativa de reparar parcialmente sua cultura, a história de exclusão social do negro no Brasil. (GIACOMINI, 2009, p. 05)

Isto se dá não apenas como forma de reparar as décadas de sofrimento e invisibilidade social a que foram acometidos. Se a criação e instalação do PNCO constituiu o capítulo mais importante para uma época de privações e violência territorial àquela comunidade, o reconhecimento e titulação das terras da tradicionais quilombola representa por outro lado início de uma nova era de prosperidade para os "filhos de Cunani", onde a dignidade, o respeito e a sustentabilidade socioambiental possam ser resgatadas, a partir da garantia da segurança fundiária, materializada pelo Título de Domínio emitido pelo INCRA. 


\section{Considerações Finais}

A previsão constitucional da titulação das terras quilombolas no Brasil se deu de forma tardia. Porém, prestes a completar três décadas desse importante marco legislativo, muito pouco foi de fato titulado e o número de famílias beneficiadas é muito baixo. O fato de a maior parte das terras tituladas terem sido aquelas situadas nas regiões que representavam menor custo financeira para o Estado e menor custo político para "quem governa" deve ser destacado, afinal, se deram em terras públicas localizadas no Norte e em rincões do Nordeste do Brasil. Os Decretos de 2003, que prometiam outro paradigma para a titulação das terras quilombolas no Brasil, constituíram fracassos não apenas do ponto de vista dos pífios resultados alcançados, mas também da constatação de que as demandas quilombolas não conseguiram sequer alcançar um papel marginal na agenda pública, quanto menos um papel de destaque.

Contudo, algumas conquistas estratégicas foram obtidas, como a consolidação de um debate acerca da condição quilombola no Brasil. É preciso, contudo, expandir cada vez mais esse olhar para a análise e avalição do papel do Estado no processo de reconhecimento destas identidades étnicas. Este tema tem se tornado cada vez mais relevante para a sociedade brasileira, tanto que se transformou num dos alvos da Comissão Parlamentar de Inquérito (CPI) na Câmara dos Deputados, cujo relatório sugere o indiciamento de servidores do INCRA, que são alvos de suspeitas de agir sem imparcialidade e impessoalidade em processos de regularização de terras quilombolas no Rio Grande do Sul. As acusações são graves e merecem o amplo direito de defesa e do contraditório, mas também servem para escancarar um problema que aflige os próprios servidores da autarquia há anos e se reflete nitidamente na baixíssima eficiência do INCRA na garantia das populações quilombolas e que foram apontados exaustivamente nesta pesquisa: falta consistência metodológica, rigor conceitual científico para estabelecer parâmetros firmes e objetivos para a definição da dita condição quilombola e da definição de seus respectivos territórios. Tanto o Decreto 4.887 de 20 de novembro de 2003 e a IN INCRA 57 de outubro de 2009 não são instrumentos que trazem qualquer segurança jurídica ou arcabouço técnico coerente para o cumprimento de demandas territoriais tão complexas e em tão larga escala e colocam os próprios 
servidores do INCRA em situação delicada na gestão do processo. O custo disso é ainda mais grave para as próprias comunidades quilombolas, uma vez que não há horizonte para que suas demandas territoriais sejam cumpridas e muito menos vontade política para superar as amarras que a legislação quilombola atual representa.

Por fim, o que se deve ressaltar é que, se em 1988 não se conhecia ao certo quem e quantas eram as comunidades quilombolas no Brasil; se ao assinar os Decretos de 2001 e 2003 esse desconhecimento persistia; é imperioso afirmar categoricamente que ainda em 2017, às vésperas de se completar trinta anos da previsão do direito constitucional, o Estado Brasileiro ainda não conhece (nem reconhece) o seu povo quilombola. Não se trata apenas de catalogar números e realizar mapeamentos ou relatórios técnicos dos órgãos oficiais, mas da paralisação do cumprimento das demandas territoriais quilombolas no Brasil, o que classifico como uma das maiores violências institucionais que uma etnia pode sofrer por parte do Estado, que é a sua permanente invisibilidade social e política.

Uma clara manifestação deste descaso do Estado com as demandas dessas populações étnicas foi demonstrada no âmbito deste trabalho, quando recuperamos o quadro das ações no Amapá e, especialmente, de como a Comunidade de Cunani vem sofrendo há décadas com tamanha violência territorial e moral. É neste momento que devo reconhecer que, como servidor público lotado no INCRA desde 2006 e no Amapá até 2013, me causou um sentimento de muita surpresa e de quase incredulidade e vergonha por ter ouvido daqueles quilombolas que a nota avaliativa que davam para o IBAMA/ICMBio, em tese a face do estado que os oprimia, era maior do que aquela atribuída ao INCRA, que é o órgão que representa sua demandas formalmente na Administração Pública.

Se perdeu pelos últimos 30 anos uma oportunidade histórica de se prover segurança fundiária para as comunidades tradicionais quilombolas no Brasil, sobretudo para atender aos interesses de grupos atingidos direta ou indiretamente pela titulação das terras, como grandes produtores rurais, ambientalistas, multinacionais do setor minerário ou grandes empresas do setor imobiliário. Trata-se de um processo muito parecido com aquele cantado nos versos de Tião Carreiro e Pardinho, o Preto Velho, que segue vivo em cada um de seus descendentes, vivendo de déu em déu, sendo sempre a madeira para o patrão, no caso o Estado, 
sempre ser o serrote.

Só nos resta trabalhar para que, desta vez, a recompensa para o povo quilombola do Brasil não seja apenas aquela que o Preto Velho só esperava vir dos céus. 


\section{Referências}

ADORNO, L.F.M. AAbordagem Geopolítica no Final do Século XX: novos e velhos paradigmas. Boletim Goiano de Geografia. Vol. 17, nำ - Jul - Dez 1997.

AGNEW, J. Territory, Politics, Governance. 1:1, 1-4, DOI: 10.1080/21622671.2013.765754. Disponível em <http://dx.doi.org/10.1080/21622671.2013.765754> Acessado em: 27/10/2015

ALBUQUERQUE, V.V.C. O Princípio da Separação dos Poderes e o Exercício da Função Normativa pelo Executivo: Paralelo entre o Direito Norte Americano e o Brasileiro. In: Ambiente Jurídico. | № 90 - Ano XIV - Julho/2011 - ISSN -1518-0360. Disponível em http://www.ambitojuridico.com.br/site/index.php?n link=revistaartigos leitura\&artigo id=9886\&revista caderno $=9$ > Acessado em 28/10/2015.

ALMEIDA, S.W.B. [Org.] et al. Cadernos de debates Nova Cartografia Social: Territórios quilombolas e conflitos. Manaus: Projeto Nova Cartografia Social da Amazônia / UEA. Edições, 2010.

ALMEIDA, B.C; PAULA, S.L. O Papel da Avaliação de Políticas Públicas no Contexto dos Governos Locais. Planejamento e Políticas Públicas - PPP. № 42, jan-jun. 2014.

AMAPÁ. LEI ESTADUAL no 1.505 de 23 de julho de 2010. Disponível em < http://www.al.ap.gov.br/ver texto lei.php?iddocumento=27337 $>$ Acessado em $27 / 06 / 2017$

ANJOS, R. S. A. Cartografia e Cultura: territórios dos remanescentes de quilombos no Brasil. In: VIII Congresso Luso-Afro-Brasileiro de Ciências Sociais. Coimbra, 16, 17 e 18 de Setembro de 2004. Disponível em < http://www.ces.uc.pt/lab2004/pdfs/rafaelsanzio.pdf> Acessado em 30 de outubro de 2015.

ARRUTI, J.M. O Quilombo entre dois governos. Revista Tempo e Presença, Rio de Janeiro, v. 25, n.330, p. 10-16, 2003.

De como a cultura se faz política e vice-versa: sobre religiões, festas, negritudes e indianidades no Nordeste contemporâneo. Comunidade Virtual de Antropologia, n.10, 2003.

Mocambo: Antropologia e história do processo de formação quilombola. 1. ed. Bauru: Edusc, 2006. 368 p.

Políticas Públicas para Quilombos: terra, saúde e educação. In: Caminhos Convergentes: Estado e Sociedade na superação das desigualdades raciais no Brasil. Orgs: Marilene de Paula, Rosana Heringer. Rio de Janeiro, Fundação Heinrich Boll, ActionAid, 2009. 
BARAVIERA, V.C.M. A Questão Racial na Legislação Brasileira. 2005. 34f. Trabalho final apresentado ao Curso de Especialização em Direito Legislativo. UNILEGIS/UFMS. Brasília, 2005.

BATISTA, E.M. Georreferenciamento de Imóveis Rurais: Aplicações e potencialidades na Amazônia Brasileira. In: II Simpósio Brasileiro de Ciências Geodésicas e Tecnologias da Geoinformação, Recife - PE, 8-11 de setembro de 2008. Disponível em < https://www.ufpe.br/cgtg/SIMGEOII CD/Organizado/cad/169.pdf > Acessado em 27/06/2017

BECKER,B.K. Revisão das políticas de ocupação da Amazônia: é possível identificar modelos para projetar cenários? Parcerias Estratégicas. №12 - Setembro de 2001.

. Geopolítica da Amazônia. Estudos Avançados 19 (53), 2005.

BOBBIO, N. O Futuro da Democracia: uma defesa das regras do jogo. Tradução de Marco Aurélio Nogueira. Rio de Janeiro: Paz e Terra, 1986.

Estado, Governo, Sociedade: por uma teoria geral da política. Tradução de Marco Aurélio Nogueira. Rio de Janeiro: Paz e Terra, 1987.

BOBBIO, N; MATTEUCCI, N. PASQUINO, G. Dicionário de Política. Tradução de Carmen C, Varriale et al.; Brasília: Editora Universidade de Brasília, 1a ed., 1998. Vol. 1: 674 p. (total: 1.330 p.)

BRAGA, S.R. Sensos, Consensos e Dissensos: Itinerários geopolíticos de Ratzel a Lacoste. Revista de Geopolítica, Ponta Grossa - PR, V.2, №1, p 146 - 163, jan jun 2011.

BRASIL. Ação Direta de Inconstitucionalidade 3.239. Disponível em < http://www.stf.jus.br/portal/geral/verPdfPaginado.asp?id=394738\&tipo=TP\&descricao =ADI\%2F3239.> Acessado em 30 de outubro de 2015.

BRASIL. Advocacia-Geral da União. Câmara de Conciliação e Arbitragem da Administração Federal - CCAF: CARTILHA. - Brasília. 2008.

BRASIL. Congresso Nacional. Câmara dos Deputados. Regimento interno da Câmara dos Deputados [recurso eletrônico] : aprovado pela Resolução № 17, de 1989, e alterado até a Resolução ํo 20, de 2016. - 18. ed. - Brasília : Câmara dos Deputados, Edições Câmara, 2017. - (Série textos básicos ; n. 141 PDF).

BRASIL. CONSTITUIÇÃO (1824). Disponível em < http://www.planalto.gov.br/ccivil_03/constituicao/constituicao24.htm> Acessado em 09/06/2017

BRASIL. CONSTITUIÇÃO (1891). Disponível em < http://www.planalto.gov.br/ccivil_03/constituicao/constituica091.htm > Acessado em 09/06/2017 
BRASIL. CONSTITUIÇÃO (1934). Disponível em < http://www.planalto.gov.br/ccivil 03/constituicao/constituicao34.htm > Acessado em 09/06/2017

BRASIL. CONSTITUIÇÃO (1937). Disponível em < http://www.planalto.gov.br/ccivil 03/constituicao/constituicao37.htm >Acessado em 09/06/2017

BRASIL. CONSTITUIÇÃO (1946). Disponível em < http://www.planalto.gov.br/ccivil 03/constituicao/constituicao46.htm >Acessado em 09/06/2017

BRASIL. CONSTITUIÇÃO (1967). Disponível em < http://www.planalto.gov.br/ccivil 03/constituicao/constituicao67.htm >Acessado em 09/06/2017

BRASIL. CONSTITUIÇÃO (1969). Disponível em < http://www.planalto.gov.br/ccivil 03/Constituicao/Emendas/Emc anterior1988/emc01 -69.htm > Acessado em 09/06/2017

BRASIL. CONSTITUIÇÃO (1988). Disponível em < http://www.planalto.gov.br/ccivil 03/constituicao/ConstituicaoCompilado.htm > Acessado em 29/10/2015

BRASIL. DECRETO № 536 de 20 de maio de 2002. Disponível em < http://www2.camara.leg.br/legin/fed/decret/1992/decreto-536-20-maio-1992-343175publicacaooriginal-1-pe.html > Acessado em 27/06/2017

BRASIL. DECRETO-LEI 5.812 de 13 de setembro de 1943. Disponível em < http://www.planalto.gov.br/ccivil 03/decreto-lei/1937-1946/Del5812.htm > Acessado em $27 / 06 / 2017$

BRASIL. DECRETO-LEI 9.760 de 05 de setembro de 1946. Disponível em < http://www.planalto.gov.br/ccivil 03/decreto-lei/Del9760.htm > Acessado em 27/06/2017

BRASIL. DECRETO-LEI № 11.049 de 17 de junho de 2009.

BRASIL. DECRETO FEDERAL № 3.912 de 10 de setembro de 2001. (Revogado pelo Decreto no 4.887, de 20.11.2003). Disponível em < http://www.planalto.gov.br/ccivil 03/decreto/2001/d3912.htm $>$ Acessado em $27 / 06 / 2017$

BRASIL. DECRETO FEDERAL № 4.340 de 22 de agosto de 2002. Disponível em < http://www.planalto.gov.br/ccivil 03/decreto/2002/d4340.htm > Acessado em $27 / 06 / 2017$

BRASIL. DECRETO FEDERAL № 4.449 de 30 de outubro de 2002. Disponível em < http://www.planalto.gov.br/ccivil 03/decreto/2002/d4449.htm > Acessado em $27 / 06 / 2017$ 
BRASIL. DECRETO FEDERAL № 4.887 de 20 de Novembro de 2003. Disponível em http://www.planalto.gov.br/ccivil 03/decreto/2003/d4887.htm Acessado em 29/10/2015. Acessado em 27/06/2017

BRASIL. DECRETO FEDERAL № 8.713 de 15 de abril de 2016. Disponível em < http://www.planalto.gov.br/ccivil 03/ ato2015-2018/2016/decreto/d8713.htm > Acessado em 27/06/2017

BRASIL. DECRETO FEDERAL № 58.824 de 14 de Julho de 1966. Disponível em < http://www.planalto.gov.br/ccivil 03/decreto/1950-1969/D58824.htm > Acessado em $27 / 06 / 2017$

BRASIL. DECRETO FEDERAL № 84.017 de 21 de Setembro de 1979. Aprova o Regulamento dos Parques Nacionais Brasileiros. Disponível em < http://www.planalto.gov.br/ccivil 03/decreto/1970-1979/D84017.htm> Acessado em 29/10/2015.

BRASIL. DECRETO FEDERAL № 84.913 de 15 de Julho de 1980. Cria, no Território Federal do Amapá, o Parque Nacional do Cabo Orange, com os limites que especifica e dá outras providências. Disponível em < http://www2.camara.leg.br/legin/fed/decret/1980-1987/decreto-84913-15-julho-1980434233-norma-pe.html> Acessado em 29/10/2015

BRASIL. DECRETO LEGISLATIVO № 20 de 1965. Disponível em < http://www2.camara.leg.br/legin/fed/decleg/1960-1969/decretolegislativo-20-30-abril1965-349517-publicacaooriginal-1-pl.html > Acessado em 27/06/2017

BRASIL. PORTARIA INTERMINISTERIAL n 210 de 13 de junho de 2014. Disponível em < https://goo.gl/CH921S > Acessado em 27/06/2017

BRASIL. Ministério da Cultura. Fundação Cultural Palmares. Portaria no 25, de 15 de agosto de 1995. Diário Oficial, Brasília, 22 ago. 1995a. Seção 1, p. 1282712828. Acessado em 27/06/2017

BRASIL. Ministério da Cultura. Fundação Cultural Palmares. Portaria no 447 de 02 de dezembro de 1999. Disponível em < http://www.cpisp.org.br/htm/leis/page.aspx?LeilD=128 > Acessado em 27/06/2017

BRASIL. PORTARIA FCP № 98 de 2007. Disponível em < https://goo.gl/TVVOrq > Acessado em 27/06/2017

BRASIL. PORTARIA INCRA № 307 de 22 de novembro de 1995. Disponível em: < https://goo.gl/eexZCp > Acessado em 27/06/2017

BRASIL. PORTARIA INCRA № 175 de 19 de abril de 2016. Disponível em < https://lex.com.br/legis 27118515 PORTARIA N 175 DE 19 DE ABRIL DE 2016 .aspx > Acessado em 27/06/2017

BRASIL. INSTRUÇÃO NORMATIVA ICMBio no 26 de 04 de julho de 2012. 
Disponível em < https://goo.gl/k23Ypi > Acessado em 27/06/2017

BRASIL. INSTRUÇÃO NORMATIVA ICMBio no 29 de 05 setembro de 2012. Disponível em < goo.gl/LUlkf9 > Acessado em 27/06/2017

BRASIL. INSTRUÇÃO NORMATIVA INCRA no 16 de 24 de março de 2004.

Disponível em < http://www.incra.gov.br/institucionall/legislacao--> Acessado em $27 / 06 / 2017$

BRASIL. INSTRUÇÃO NORMATIVA INCRA no 20 de 19 de setembro de 2005. Disponível em < http://www.incra.gov.br/institucionall/legislacao--> Acessado em $27 / 06 / 2017$

BRASIL. INSTRUÇÃO NORMATIVA INCRA no 49 de 29 de setembro de 2008. Disponível em < http://www.incra.gov.br/institucionall/legislacao--> Acessado em $27 / 06 / 2017$

BRASIL. INSTRUÇÃO NORMATIVA INCRA no 56 de 07 de outubro de 2009. Disponível em < http://www.incra.gov.br/institucionall/legislacao--> Acessado em $27 / 06 / 2017$

BRASIL. INSTRUÇÃO NORMATIVA INCRA n 57 de 20 de outubro de 2009. Disponível em < http://www.incra.gov.br/institucionall/legislacao--> Acessado em $27 / 06 / 2017$

BRASIL. INCRA. Ofício № 692/2013 - GAB/INCRA/AP (Acervo institucional analógico).

BRASIL. INCRA. PROCESSO ADMINISTRATIVO 54350.000346/2004-07.

Superintendência Regional do Amapá. (acervo analógico).

BRASIL. LEI no 04 de 10 de junho de 1835. Disponível em < http://www.planalto.gov.br/ccivil 03/leis/lim/LIM4.htm > Acessado em 27/06/2017

BRASIL. LEI 16 de Dezembro de 1830. (Revogado pelo Decreto-Lei no 2.375, de 24.11.1987). Disponível em < http://www.planalto.gov.br/ccivil 03/leis/lim/LIM-16-121830.htm > Acessado em 27/06/2017

BRASIL. LEl 1.164 de 01 de Abril de 1971. Disponível em < http://www.planalto.gov.br/ccivil 03/decreto-lei/Del1164.htm > Acessado em 27/06/2017

BRASIL. LEI 3.310 de 15 de outubro de 1886. Disponível em < http://www.planalto.gov.br/ccivil 03/leis/lim/LIM3310.htm > Acessado em 27/06/2017

BRASIL. LEI FEDERAL 4.504 de 30 de novembro de 1964. Disponível em < http://www.planalto.gov.br/ccivil 03/leis/L4504.htm > Acessado em 27/06/2017

BRASIL. LEI FEDERAL № 4.771 de 15 de Setembro de 1965. Institui o novo código florestal (revogado pela Lei Federal 12.651). Disponível em < http://www.planalto.gov.br/ccivil 03/Leis/L4771.htm> Acessado em 29/10/1965. 
BRASIL. LEI FEDERAL № 6.015, de Dezembro de 1973. Dispõe sobre os registros públicos, e dá outras providências. Disponível em: < http://www.planalto.gov.br/ccivil 03/leis/L6015original.htm > Acessado em 29/10/2015.

BRASIL. LEI FEDERAL № 6.383 de 07 de dezembro de 1976. Disponível em < http://www.planalto.gov.br/ccivil 03/leis/L6383.htm > Acessado em 27/06/2017

BRASIL. LEI FEDERAL № 6.938 de 31 de agosto de 1981. Disponível em < http://www.planalto.gov.br/ccivil 03/leis/L6938.htm > Acessado em 27/06/2017

BRASIL. LEI FEDERAL № 7.804 de 18 de julho de 1989. Disponível em < http://www.planalto.gov.br/ccivil 03/leis/L7804.htm > Acessado em 27/06/2017

BRASIL. LEI FEDERAL № 10.267, de 28 de Agosto de 2001. Disponível em < http://www.planalto.gov.br/CCivil 03/Leis/LEIS 2001/L10267.htm > Acessado em 30 de outubro de 2015.

BRASIL. LEI FEDERAL $\mathrm{n} \times \mathbf{1 0 . 3 0 4}$ de 05 de Novembro de 2001. Disponível em < http://www.planalto.gov.br/ccivil 03/leis/leis 2001/L10304.htm > Acessado em $27 / 06 / 2017$

BRASIL. LEI FEDERAL № 12.651 de 25 de Maio de 2012. Disponível em < http://www.planalto.gov.br/ccivil 03/ Ato2011-2014/2012/Lei/L12651.htm\#art83> Acessado em 29/10/2015.

BRASIL. MEDIDA PROVISÓRIA 1.911 de 29 de julho de 1999. Disponível em < http://www.planalto.gov.br/ccivil 03/mpv/Antigas/1911-8.htm $>$ Acessado em $27 / 06 / 2017$

BRASIL. Ministério Público Federal. Câmara de Coordenação e Revisão, 6. Territórios de povos e comunidades tradicionais e as unidades de conservação de proteção integral: alternativas para o asseguramento de direitos socioambientais / 6. Câmara de Coordenação e Revisão; coordenação Maria Luiza Grabner; redação Eliane Simões, Débora Stucchi. - Brasília : MPF, 2014.

BRASIL. Ministério Público Federal. Câmara de Coordenação e Revisão, 6. Ata da Audiência Pública sobre a Ação do MPF na Defesa das Comunidades Quilombolas. Sede da Procuradoria-Geral da República. 20 de novembro de 2013. Disponível em < goo.gl/UOs7W2 > Acessado em 27/06/2017

BRASIL. Ministério Público Federal - Procuradoria da República no Estado do Amapá. Ação Civil Pública 3465-49.2009.4.01.3100 de 2009.

BRASIL. Ministério Público Federal - Procuradoria da República no Estado do Amapá. Recomendação № 12 de 2007. Disponível em < http://www.mpf.mp.br/atuacao-tematica/ccr4/dados-da-atuacao/documentos/base-dedados/recomendacoes/2007/rec012 PR-AP.pdf > Acessado em 27/06/2017

BRASIL. Ministério Público Federal - Procuradoria da República no Estado do 
Amapá. Recomendação № 24 de 2012.

BRASIL. Ministério Público Federal - Procuradoria da República no Estado do Amapá. Recomendação № 21 de 2013.

BRASIL. Ministério Público Federal - Procuradoria da República no Estado do Amapá. Recomendação № 26 de 2013.

BRASIL. Ministério Público Federal - Procuradoria da República no Estado do Amapá. Recomendação № 16 de 2014. Disponível em < http://www.mpf.mp.br/ap/atuacao/recomendacoes/recomendacoes2014/016 2014.pdf > Acessado em 27/06/2017

BRASIL. Ministério Público Federal - Procuradoria da República no Estado do Amapá. Recomendação № 06 de 2015. Disponível em < http://www.mpf.mp.br/ap/atuacao/recomendacoes/recomendacoes-2015/0062015.pdf > Acessado em 27/06/2017

BRASIL. Ministério Público Federal - Procuradoria da República no Estado do Amapá. Recomendação № 46 de 2015. Disponível em < http://www.mpf.mp.br/ap/atuacao/recomendacoes/recomendacoes2015/046 2015.pdf >

BRASIL. Ministério Público Federal - Procuradoria da República no Estado do Amapá. Recomendação № 47 de 2015. Disponível em < http://www.mpf.mp.br/ap/atuacao/recomendacoes/recomendacoes2015/047 2015.pdf >

BRASIL. MENSAGEM PRESIDENCIAL № $\mathbf{3 7 0}$ de $\mathbf{1 3}$ de maio de 2002. Disponível em: < http://www.planalto.gov.br/ccivil 03/VETO TOTAL/2002/Mv370-02.htm > Acessado em 27/06/2017

BRASIL. PODER JUDICIÁRIO. Tribunal Regional Federal da Primeira Região. SubSeção Judiciária de Oiapoque. Processo № 0000005-38.2015.4.01.3102 DECISÃO. Disponível em < http://app.tjap.jus.br/tucujuris/publico/processo/index.xhtml > Acessado em $27 / 06 / 2017$

BRASIL. Projeto de Lei do Senado no 129 de 1995. Disponível em < https://goo.gl/nH5jSn > Acessado em 27/06/2017

BRASIL. Projeto de Lei no 627 de 1995. Disponível em < https://goo.gl/XGp5am > Acessado em 27/06/2017

BRASIL. Projeto de Lei no 3.654 de 2008. Disponível em < https://goo.gl/7Ul8PU > Acessado em 27/06/2017

CARVALHO, A.P.C. Tecnologias de governo, regularização de territórios quilombolas... In: Horizontes Antropológicos, Porto Alegre, ano 22, n. 46, p. 131 157, jul./dez. 2016. Disponível em < http://dx.doi.org/10.1590/S0104- 
$\underline{71832016000200005}>$ Acessado em 27/06/2017

CARRIL, L.F.B. Quilombo, Território e Geografia. AGRÁRIA, São Paulo, № 3, pp. 156-171, 2006. Disponível em < www.revistas.usp.br/agraria/article/download/92/91> Acessado em 30 de outubro de 2015.

CASTRO, E. Território, biodiversidade e saberes das populações tradicionais. Papers do NAEA. 1998.

CHACPE, J. F. Territórios Quilombolas e Unidades de Conservação de Proteção Integral: desafios da conciliação na Administração Federal. 2014. 150f. Dissertação de Mestrado. Centro de Desenvolvimento Sustentável. Universidade de Brasília. Brasília, 2014.

COMISSÃO PASTORAL DA TERRA. Conflitos no Campo. CPT Nacional: Brasil. 2012. Disponível em <

http://www.cptnacional.org.br/index.php?ltemid=23\&view=finish\&cid=316\&catid=43> Acessado em 30/10/2015

COMISSÃO PASTORAL DA TERRA. Conflitos no Campo. CPT Nacional:Brasil. 2013. Disponível em < http://cptnacional.org.br/index.php?ltemid=23\&view=finish\&cid=344\&catid=43> Acessado em 30/10/2015

COMISSÃO PASTORAL DA TERRA. Conflitos no Campo. CPT Nacional: Brasil. 2014. <

http://www.cptnacional.org.br/index.php? Itemid=23\&view=finish\&cid=2392\&catid=43 $>$ Acessado em 30/10/2015

COMISSÃO PASTORAL DA TERRA. CPT e bispo do Amapá se reúnem com governo do estado para discutir grilagem no campo e combate à violência. Disponível em < https://goo.gl//73KEF > Acessado em 30 de outubro de 2015.

COMISSÃO PRÓ-ÍNDIO DE SÃO PAULO (CPI-SP). Disponível em < http://www.cpisp.org.br/ > Acessado em 27/06/2017

COORDENAÇÃO NACIONAL DE ARTICULAÇÃO DAS COMUNIDADES NEGRAS RURAIS (CONAQ). Disponível em < www.conaq.org.br > Acessado em27/06/2017

CONVENÇÃo NACIONAL DO NEGRO PELA CONSTITUINTE. 26 A 27 de Agosto de 1986. Brasília/DF. Disponível em < goo.gl/Fczxbq > Acessado em 27/06/2017

CORREA, R. L. Os Centros de Gestão do Território: Uma Nota. In: Revista Território, 1 (1), 1996.

COSTA, W.M. Geografia Política e Geografia: Discursos sobre o território e o poder. Editora Hucitec. São Paulo: 1992. 
CPISP. Terras de Quilombo: Balanço 2009. Comissão Pró-Índio de São Paulo, 2009. Disponível em: < https://goo.gl/kaKJO9 > Acessado em 27/06/2017

DAHL, R.A. The Behaviorall Approach in Poliiical Science: Eptiaph lor a Monument lo a Sucessful Protest. In American Pontual Science Review, LV, September 1961, pp. 763-72

De PAULA, Ana P. P. Por uma nova gestão pública : limites e potencialidades da experiência contemporânea. Rio de Janeiro: FGV, 2005.

DIEGUES, A.C.S. O Mito Moderno da Natureza Intocada. Editora Hucitec. São Paulo: 2001.

DOMINGUES, P. Movimento Negro Brasileiro: alguns apontamentos históricos. In: Tempo. 2007.

DOS ANJOS, R. S. A. Cartografia e Quilombos: territórios étnicos africanos no Brasil. In: Africana Studia. № 09, 2006. Edição do Centro de Estudos Africanos da Universidade do Porto. (CEAUP).

FAGUNDES, H.; MOURA, A. B. de. Avaliação de programas e políticas públicas. Revista Textos \& Contextos, v. 8, n.1, Porto Alegre, jan./jun. 2009, p. 89-103.

FARIA, C.A.P. A política de avaliação de políticas públicas. Revista Brasileira de Ciências Sociais. Vol. 20, n־59

FERNANDES, B. M. O MST e as Reformas Agrárias no Brasil. Boletim DATALUTA. Artigo do mês: dezembro de 2008. ISSN 2177-4463

FARIAS JUNIOR, E.A.F. Do Rio dos Pretos ao Quilombo do Tambor. Revista EDUCAMAZÔNIA - Educação Sociedade e Meio Ambiente, Humaitá, LAPESAM, GISREA/UFAM/CNPq/EDUA - ISSN 1983-3423 - Ano 3, Vol 1, jan-jun, 2010, Pág. 147-165. Disponível em < dialnet.unirioja.es/descarga/articulo/4002448.pdf > Acessado em 30 de outubro de 2015.

FELLET, J. Governo Temer trava demarcações de áreas quilombolas - BBC Brasil. 18 de abril de 2017. Disponível em < http://www.bbc.com/portuguese/brasil39625624> Acessado em 31/05/2017.

FIABANI, A. Mato, palhoça e pilão: o quilombo, da escravidão às comunidades remanescentes [1532-2004]. São Paulo: Expressão Popular, 2005.

. O Quilombo Antigo e o Quilombo Contemporâneo. Verdades e construções. In: XXIV Simpósio Nacional de História, 2007. Disponível em < http://snh2007.anpuh.org/resources/content/anais/Adelmir\%20Fiabani.pdf > Acessado em 27/06/2017

Os Novos Quilombos: Luta pela Terra e afirmação étnica no Brasil [1988-2008]. 2008. 275 p. Tese (Doutorado em História). Universidade do Vale do Rio dos Sinos. São Leopoldo, 2008. 
Em Busca da Terra Prometida. Revista Convergência Crítica. N.04, 2014. ISSN 2238-9288.

FRANCO, J. L.A; DRUMOND, J.A. Terras de Quilombolas e Unidades de Conservação: uma discussão conceitual e política, com ênfase nos prejuízos para a conservação da natureza. Territórios Quilombolas e Unidades de Conservação. Grupo Iguaçu, 2009.

. A Invenção de um quilombo no Parque Nacional do Jaú: a arte de semear conflitos. Territórios Quilombolas e Unidades de Conservação. Grupo Iguaçu, 2009

. Ameaças a biodiversidade nos Parques Nacionais de Aparados da Serra e Serra Geral: o surgimento de uma suposta comunidade remanescente de quilombo. Territórios Quilombolas e Unidades de Conservação. Grupo Iguaçu, 2009

FREY, K. Políticas Públicas: um debate conceitual e reflexões referentes à prática da análise das políticas públicas no Brasil. Planejamento e Políticas Públicas. №21, JUN/2000.

FRANCO, R.; COHEN, E. Evaluación de Proyectos Sociales. Bogotá: Siglo XXI. 1992.

FREITAS, $\mathrm{H}$ et al. . O método de pesquisa survey. Revista de Administração, São Paulo,v.35, nn. 3, n.3, jul/set, 2000.

GIACOMINI, R. L. B. A Territorialidade das Comunidades de Quilombos no Vale do Ribeira: do direito étnico a posse definitiva do território. In: XIX Encontro Nacional de Geografia Agrária. São Paulo: 2009. P:1-33.

GIL, A.C. Métodos e técnicas de pesquisa social. São Paulo: Atlas, 1991.

GODOY, L.S. Os Pressupostos Jurídicos para Regularização Fundiária das Áreas Remanescentes de Comunidades de Quilombos. Quilombos em São Paulo tradições, direitos e lutas. São Paulo: ITESP, 1997: p. 63-68.

GOMES, F. S. Negros e Política (1888-1937). Rio de Janeiro: Jorge Zahar Editor. 2005. 92p.

GUARIM, V.L. Sustentabilidade Ambiental em Comunidades Ribeirinhas Tradicionais. In: III Simpósio sobre Recursos Naturais e Sócio-Econômicos do Pantanal. De 27 a 30 de Novembro de 2000. Disponível em < http://www.cpap.embrapa.br/agencia/congresso/Socio/GUARIM-072.pdf> Acessado em 30 de outubro de 2015.

HAESBAERT, R. Região, diversidade territorial e globalização. Revista Geographia - Ano 1, no1 - 1.999. 
. O mito da desterritorialização: do "fim dos territórios" à multiterritorialidade. Rio de Janeiro: Bertrand Brasil. 2004.

- Da desterritorialização à multiterritorialidade. Anais do X Encontro de Geógrafos da América Latina - 20 a 26 de março de 2005 - Universidade deSão Paulo.

INESC. Orçamento Quilombola: governo federal orça mas não gasta. Nota Técnica INESC nำ126. Março de 2007.

. Orçamento Quilombola: entre o previsto e o gasto. Nota Técnica INESC no 139. Julho de 2008.

. Orçamento Quilombola 2008 - 2010: e a maquiagem na titulação. Nota Técnica INESC nำ168. Julho de 2010.

O orçamento das políticas federais de promoção da igualdade racial e combate ao racismo: baixa prioridade e execução. Nota Técnica INESC no 179. Novembro de 2012.

JORGE, A.L. O Movimento Social Quilombola. Considerações sobre sua origem e trajetória. Revista Vértices. Campos dos Goytacazes/RJ, v.17, n. 03, p. 139-151, set/dez. 2015.

LASCOUMES. Pratiques et modèles de l'evaluation. In: KRESSLER, Marie Christine et al (Orgs). Evaluation des politiques publiques. Paris: L'harmattan, 1988. P. 23-33.

LEITE, I.B. Territórios Quilombolas: reconhecimento e titulação das terras. Boletim Informativo do NUER - 2. ed. Florianópolis: NUER, 2005. v. 1. 262p.

LIMA, R. A. P. ; JUCA, T. S. S. Conflitos entre o Parque Nacional do Cabo Orange e a Comunidade Remanescente do Quilombo de Cunani, no Estado do Amapá. In:

Boletim Amazônico de Geografia. (ISSN: 2358-7040 - on line), Belém, v. 02, n. 03, p. 153-174. jan./jun. 2015.

LIMA,R.A. P; PORTO, J.L. R. Ordenamento Territorial Amapaense: Dinamicas de um estado brasileiro na fronteira amazônica. In: X Coloquio Internacional de

Geocrítica: Diez anos de cambios en el mundo, en la geografia y las ciencias sociales, 1999-2008. Barcelona, 2008. Disponível em < http://www.ub.edu/geocrit/xcol/100.htm > Acessado em 30 de outubro de 2015.

LISBOA, A.R.F. Revisitando Montesquieu: uma análise contemporânea da teoria da separação dos poderes. In: Âmbito Jurídico, Rio Grande, Ano XI, nํ52, Abr. 2008. Disponível em < http://www.ambito-juridico.com.br/site/index.php?n link=revista artigos leitura\&artig o id=2670 > Acessado em 30/10/2015. 
LOCKE. J. Segundo Tratado do Governo Civil. Tradução de Marta Lopes e Marisa Lobo da Costa. Editora Vozes. Distribuição: Clube do Livro Liberal. 2006. Disponível em < http://www.xr.pro.br/IF/LOCKE-Segundo tratado Sobre O Governo.pdf > Acessado em 30/10/2015.

KORNIJEZUK, N.B.S. Cultura e Biodiversidade: uma comparação entre a gestão do Parque Nacional do Cabo Orange, no Brasil, e a do Parque Nacional da Vanoise, na França. 2012. 214f. Tese de Doutorado. Centro de Desenvolvimento Sustentável. Universidade de Brasília. Brasília, 2012.

KOHLHEPP, G. Conflitos de Interesse no Ordenamento Territorial da Amazônia Brasileira. In: Estudos Avançados 16 (45). 2002.

MAARA/INCRA. Aspectos Sócio-Econômicos e Fundiários da Bacia do Rio Trombetas localizada no município de Oriximiná. Ministério da Agricultura, do Abastecimento e da Reforma Agrária/INCRA. Brasília, abril de 1994.

MAGNOLI, Demétrio. Uma gota de sangue. História do Pensamento Racial. São Paulo: Contexto. 2008. 400p.

MDA. II PLANO NACIONAL DE REFORMA AGRÁRIA. 2003. Disponível em < http://sistemas.mda.gov.br/arquivos/PNRA 2004.pdf > Acessado em 29/10/2015.

MEDEIROS, M. A trajetória do Welfare State no Brasil. Papel redistributivo das políticas públics sociais dos anos 1930 aos anos 1990. IPEA: Texto para Discussão ํo 852. ISSN: 1415-4765. Brasília, dezembro de 2001.

MELO, G. M. A Leitura da Gestão dos Parques Nacionais Sob a Ótica das Populações Locais: os Parques Nacionais Montanhas do Tumucumaque e Cabo Orange. 2007. 115f. Dissertação Mestrado. - Universidade Federal do Rio de Janeiro - UFRJ, Programa de Pós Graduação em Psicossociologia de Comunidades e Ecologia Social - EICOS, 2007.

MELLO. N. A. Contradições Territoriais: signos do modelo aplicado na Amazônia. Sociedade e Estado, Brasília, v. 18, n. 1/2, p. 339-360, jan./dez. 2003. Disponível em < http://www.scielo.br/pdf/se/v18n1-2/v18n1a15.pdf $>$ Acessado em 12/06/2017.

MELLO-THERY, N.A. de. Políticas Territoriais na Amazônia. São Paulo: Annablume, 2006.

Território e Gestão Ambiental na Amazônia. Terras públicas e os dilemas do Estado. São Paulo: Annablume, 2011.

(b). Política (e ação) Pública, território e o papel da geografia.

Revista da ANPEGE. V7. no1, número especial, pág. 11-19, out. 2011.

MONTESQUIEU, C.L.S. O Espírito das Leis. Tradução de Fernando Henrique Cardoso e Leôncio Martins Rodrigues. Brasília: Editora Universidade de Brasília, 1995. 556 p. 
NASCIMENTO, A. O Quilombismo. 2 ed. Brasília/Rio: Fundação Cultural Palmares; O.R. Editora, 2002. Disponível em < http://www.abdias.com.br/movimneto negro/quilombismo.htm > Acessado em $27 / 06 / 2017$

NASCIMENTO, A. G. A Reforma Agrária no Estado do Amapá: o processo histórico-institucional fundiário e as consequências dos projetos de assentamento sobre a cobertura florestal. Dissertação de Mestrado. Programa de Pós-Graduação em Direito Ambiental - UNIFAP. Macapá, 2009.

NYE JR., J.S. O Futuro do Poder. Tradução de Magda Lopes. São Paulo:Benvirá, 2012.

O'DWYER, E. C. Estratégias de redefinição do Estado no contexto de reconhecimento das Terras de Quilombo no Brasil. Novos Debates, v. 1, p. 80-86, 2014.

OIT. Convenção 107 da Organização Internacional do Trabalho Sobre Populações Indígenas e Tribais de 1957 / Organização Internacional do Trabalho. Disponível em < https://goo.gl/Drn9eZ > Acessado em 27/06/2017

OIT. Convenção $n^{\circ} 169$ sobre povos indígenas e tribais e Resolução referente à ação da OIT / Organização Internacional do Trabalho. - Brasilia: OIT, 2011. Disponível em < http://portal.iphan.gov.br/uploads/ckfinder/arquivos/Convencao 169 OIT.pdf>

OLIVEIRA, A.U. Amazônia: monopólio expropriação e conflito. Campinas: Editora Papirus, 1995.

OMMATI, F. Dos Freios e Contrapesos entre os Poderes do Estado. Revista Inf. Legisl. Brasília. Ano 14, ํo55, jul - set, 1977.

PAGLIARINI, M.; BATISTA, E. M. Uso da tecnologia GPS para intermediação de conflitos agrários. II Simpósio Brasileiro de Ciências Geodésicas e Tecnologias da Geoinformação. Recife - PE, 8-11 de setembro de 2008. Disponível em < https://www.ufpe.br/cgtg/SIMGEOII CD/Organizado/geo/107.pdf > Acessado em 30 de outubro de 2015.

PRICE, R. Maroons Societies: Rebel slaves communities in the Americas. The John Hopkins University Press: Baltimore and London. Third edition, 1996.

Maroons: Rebel Slaves in the Americas. This article was originally published in the 1992 Festival of American Folklife. Disponível em < http://www.folklife.si.edu/resources/maroon/educational guide/23.htm $>$ Acessado em 11/06/2017.

PORTO, J.L.R. Transformações Espaciais e Institucionais do Amapá: Conflitos e perspectivas. In: Anais do X Encontro de Geógrafos da América Latina - 20 a 26 de março de 2005 - Universidade de São Paulo. 
QUEIROZ, J.M. História, Mito e Memória: o Cunani e outras repúblicas. In: GOMES, F.S (org). Nas terras do Cabo Norte: fronteiras, colonização e escravidão na Guiana Brasileira (séculos XVIII-XIX). XVIII-XIX). 1988. p333-4.

RAFFESTIN, C. Por uma Geografia do Poder. Tradução de Maria Cecília França. São Paulo: Editora Ática. 1993. 269p.

REIS, A.C.F. Território do Amapá - perfil histórico. Rio de Janeiro: Departamento de Imprensa Nacional, 1949.

REIS, J.J.; GOMES, F.S. Quilombo: Brazilian maroons during slavery. In: Cultural Survival Quarterly Magazine. Dezembro de 2001. Disponível em:

$<$ https://www.culturalsurvival.org/publications/cultural-survival-quarterly/quilombobrazilian-maroons-during-slavery > Acessado em 11/06/2017.

RIBEIRO, J.G.; ESTENDER, A.C.; JULIANO, M.C. Reserva Extrativista do Quilombo Frechal. Observatório do Negro. Disponível em < http://www.observatoriodonegro.org.br/index.php/10-artigos/55-reserva-extrativistasdo-quilombo-frechal > Acessado em 27/06/2017

ROCHA, M.I.C. Estado e Governo: Diferença conceitual e implicações práticas na pós-modernidade. Revista UNIARA, n² 21/22, 2008/2009.

RODRIGUES, R.J.P. Desenvolvimento das Ações Políticas da Sociedade Civil Dentro e Fora do Congresso Nacional. (Consultoria Legislativa da Câmara dos Deputados) . Biblioteca Digital da Câmara dos Deputados. 2000. Disponível em < https://goo.gl/tEic3a > Acessado em 27/06/2017

RODRIGUES, L. C. Propostas para uma Avaliação em Profundidade de Políticas Públicas Sociais. In: Revista Avaliação de Políticas Públicas. № 10, Jan/Jun 2008.

RODRIGUES, V. Programa Brasil Quilombola: Um ensaio sobre a política pública de promoção da igualdade racial para comunidades de quilombos. In: Cadernos Gestão Pública e Cidadania / v. 15, n. 57. São Paulo: 2010

. Entre Quilombos e Palenques: Um estudo antropológico sobre políticas públicas de reconhecimento no Brasil e na Colômbia. 2012. Tese de Doutorado. Faculdade de Filosofia, Letras e Ciências Humanas do Curso de Pós Graduação em Ciências Sociais - Universidade de São Paulo. São Paulo, 2012.

RUCKERT, A. A. Políticas Territoriais, Ciência \& Tecnologia e a Ação de Atores Locais e Regionais. Sociologias, Porto Alegre, ano 6, no 11, jan/jun 2004, p. 148183. Disponível em < http://www.scielo.br/pdf/soc/n11/n11a08.pdf $>$ Acessado em 12/06/2017.

. Uso do Território e Políticas Territoriais Contemporâneas: Alguns cenários no Brasil, União Europeia e Mercosul. Revista de Geopolítica. Ponta Grossa - PR. V.1, N.1, p.17-32, Jan/Jun. 2010. 
SANTOS, S. R. Comunidades Quilombolas: As lutas por reconhecimento de direitos na esfera pública brasileira. 2012. Tese de Doutorado em Serviço Social. Programa de Pós-Graduação da Faculdade de Serviço Social, Faculdade de Serviço Social, Pontifícia Universidade Católica do Rio Grande do Sul. Porto Alegre, 2012.

SANTOS, V.M; VERRIER, P. E. Le Management Public. Paris: PUG, 1993.

SEPPIR. Guia de Políticas Públicas para Comunidades Quilombolas. Brasília, 2013. Disponível em: < http://www.seppir.gov.br/portal-antigo/arquivos-pdf/guia-pbq> Acessado em 30 de outubro de 2015.

SILVA, D. S. Apontamentos para Compreender a Origem e Propostas de Regulamentação do Artigo 68 do Ato das Disposições Constitucionais Transitórias de 1988. In: Boletim NUER/FCP. V.1, N.1, 2ed. Florianópolis, 1997.

SILVA, M.G. Territórios Quilombolas no Estado do Amapá: um diagnóstico. In: XXI Encontro Nacional de Geografia Agrária. Uberlândia - MG. 1519 de outubro de 2012.

. Políticas Públicas, Território e Poder: Uma Análise Acerca das Políticas Públicas de Gestão do Território na Amazônia Brasileira. In: III CONGRESO INTERNACIONAL DE ORDENAMIENTO TERRITORIAL Y TECNOLOGIAS DE LA INFORMACION GEOGRAFICA, 2014, Buenos Aires. Não há. 2014.

SILVA, M. G da. (Org.); Lomba, Roni Mayer (Org.) ; Rangel, Kátia de Souza (Org.); SILVA, Geovane Grangeiro da. (Org.) ;. Conflito, Territorialidade e Desenvolvimento: Algumas reflexões sobre o campo amapaense. $1^{1}$ a ed. Dourados/MS: UFGD, 2014. v. 1. 144p .

SILVA, M.G; MELLO-THERY, N.A. Políticas Públicas, Território e Poder: uma análise sobre a política de regularização de territórios quilombolas na Amazônia brasileira. In: XI Encontro Nacional da ANPEGE. 09 a 12 de outubro de 2015.

. A Política de Regularização de Territórios Quilombolas: uma contribuição para a análise e avaliação. In: VII Simpósio Internacional de Geografia Agrária, VIII Simpósio Nacional de Geografia Agrária e Jornada das Águas e Comunidades Tradicionais. 30 de outubro a 03 de novembro de 2015. Universidade Federal de Goiás (UFG), Goiânia-GO

SHERMAN GE, SUTTON T, BLAZEK R, HOLL S, DASSAU O, MORELY B, MITCHELL T AND LUTHMAN L. 2011. Quantum GIS User Guide - Version 1.7 "Wroclaw". Disponível em: <http://download.osgeo.org/qgis/doc/manual/qgis1.7 .0 user guide en.pdf">http://download.osgeo.org/qgis/doc/manual/qgis1.7.0 user guide en.pdf $>$ Acessado em: 12/06/2017.

SOUZA, A. L; FILIPPI, E.E. O Programa Amazônia Sustentável. Novas e velhas estratégias de inserção continental. Amazônia: Ci. \& Desenv., Belém, v6, nำ11, jul./dez. 2010.

SOUZA, C. "Estado do Campo" da pesquisa em políticas públicas no Brasil. Revista Brasileira de Ciências Sociais. Vol 18, nํ51. Fev/2003. 
SOUZA, C. Políticas Públicas: uma revisão da literatura. Sociologia, Porto Alegre. Ano 08, no16, jul-dez de 2006.

SOUZA, J.G. Limites do Território. Agrária, São Paulo, no 10/11, pp. 99-130, 2009.

SOUZA, O. B. O que o Governo Dilma fez (e não fez) pelos territórios quilombolas? Instituto Socioambiental - ISA. 14 de junho de 2016. Disponível em < https://www.socioambiental.org/pt-br/noticias-socioambientais/o-que-o-governodilma-fez-e-nao-fez-pelos-territorios-quilombolas > Acessado em 27/06/2017.

TAVARES, F.B. Os conflitos agrários e o processo de reordenamento fundiário na região sudeste do Pará: uma proposta de abordagem a partir da sociologia dos regimes de ação. In: Revista Ideas: Interfaces em Desenvolvimento, Agricultura e Sociedade. v. 3, n. especial, p. 440-474, 2009.

TENÓRIO, F. Gestão social: uma perspectiva conceitual. Revista de Administração Pública, v. 32, n. 5, p. 7-23, 1998.

TIÃO CARREIRO E PARDINHO. Preto Velho. In: Navalha na Carne. Gravadora Warner Music / WM Records. 2000. CD (digital).

TINOCO, D.S.; SOUZA, L.M.; OLIVEIRA, A.B. Avaliação de Políticas Públicas: modelos tradicional de pluralista. Revista de Políticas Públicas, São Luiz, v.15, n0.02, jul - dez de 2011.

TREVISAN, A.P; van BELEN, H.M. Avaliação de políticas públicas: uma revisão teórica de um campo em construção. Revista de Administração Pública. Rio de Janeiro 42(3):529-50, MAI/JUN 2008.

TRUMAN, D. B. The governmental process: Political interests and public opinion. New York: Alfred A. Knopf. 2008.

VARGAS, G.M.; BASTOS, C.M. Conflitos ambientais urbanos e processos de urbanização na Ressaca Lagoa dos Índios em Macapá/AP. Cadernos Metrópole, vol. 15, núm. 29, jan/jun, 2013, pp. 265-288.

VEIGA RIOS, A. V. Quilombos: Raízes, conceitos, perspectivas. In: Regulamentação de Terras de Negros no Brasil. Boletim Informativo NUER, Vol I, nº1. Florianópolis: UFSC, 1996: 65-77.

VERDUM, R. Território Quilombola, Terra de Direito. Boletim INESC 26. Ano X. Outubro de 2011.

VERDUM, R. A Recorrente Baixa Execução Orçamentária. In: Violência contra os Povos Indígenas no Brasil - Dados de 2014, Brasília: Conselho Indigenista Missionário, 2015, pp. 30-36.

VESENTINI, J.W. Novas Geopolíticas: As representações do século XXI. 2ª Ed. São Paulo: Editora Contexto, 2003. 
VIANNA, A.L. Abordagens Metodológicas em Políticas Públicas. Revista da Administração Pública. Rio de Janeiro, 30 (2). Mar - Abr de 1996.

\section{Fontes Eletrônicas}

INCRA. Quadro Geral da Política de Regularização de Territórios Quilombolas. Disponível em <HTTP://www.incra.gov.br/quilombolas> Acessado em 01/07/2017.

INCRA. Coordenação de Regularização de Territórios Quilombolas. Publicação eletrônica [mensagem pessoal]. Mensagem recebida por < marcelo.engufu@gmail.com > em 20/02/2017.

MPF/AP. Procuradoria da Republica no Amapá - Ministério Público Federal. Disponível em < https://goo.gl/nKbA42 >

MPF. Procuradoria Geral da República - Ministério Público Federal - 6a Câmara de Coordenação e Revisão. Disponível em < http://www.mpf.mp.br/atuacaotematica/ccr6 >

MPOG. Glossário do Orçamento Federal. Disponível em $<$ HTTP://www.orcamentofederal.gov.br/glossario-1/glossario view?letra=D> Acessado em 01/07/2015.

PROJETO NOVA CARTOGRAFIA SOCIAL DA AMAZONIA. Disponível em < http://novacartografiasocial.com/> Acessado em 08/06/2017.

SPU. Coordenação-Geral de Habitação e Regularização Fundiária. Publicação eletrônica [mensagem pessoal]. Mensagem recebida por < marcelo.engufu@gmail.com > em 17/03/2017. 
ANEXO A - Dados orçamentários, financeiros e de resultados alcançados. (Fonte: INCRA)

AREA TITULADA

$\begin{array}{lccc}\text { Região } & \text { Área Total 1995-03 } & \text { Área INCRA 1995-03 } & \text { \% Área 1995-03 INCRA } \\ \text { Norte } & 541.330,0 & 96.100,00 & 17,8 \\ \text { Nordeste } & 32.130,0 & - & - \\ \text { Centro-Oeste } & 267.348,5 & - & - \\ \text { Sudeste } & 18.273,9 & - & - \\ \text { Sul } & - & - & - \\ \text { Total } & 859.082,3 & 96.100,00 & 11,2\end{array}$

$\begin{array}{lccc} & \text { Área Total 2004-07 } & \text { Área INCRA 2004-07 } & \text { \% Área INCRA 2004-07 } \\ \text { Norte } & 29.637,11 & 14.799,00 & 49,9 \\ \text { Nordeste } & 38.776,80 & 12.372,30 & 31,9 \\ \text { Centro-Oeste } & 73,3 & - & - \\ \text { Sudeste } & 1.869,60 & - & - \\ \text { Sul } & - & - & - \\ \text { Total } & 70.356,80 & 27.171,30 & 38,6\end{array}$

$\begin{array}{lccc} & \text { Área Total 2008-11 } & \text { Área INCRA 2008-11 } & \% \text { Área INCRA 2008-11 } \\ \text { Norte } & 35.360,70 & 11.608,60 & 32,8 \\ \text { Nordeste } & 17.007,60 & 8.125,40 & 47,8 \\ \text { Centro-Oeste } & 333,1 & 333,1 & 100 \\ \text { Sudeste } & 2.125,70 & 2.125,70 & 100 \\ \text { Sul } & 1.209,30 & 1.209,30 & 100 \\ \text { Total } & 56.036,40 & 23.402,00 & 41,8\end{array}$

$\begin{array}{lccc} & \text { Área Total } 2012-15 & \text { Área INCRA 2012-15 } & \text { \% Área INCRA 2012-15 } \\ \text { Norte } & 13.239,60 & - & - \\ \text { Nordeste } & 27.483,30 & 5.419,20 & 19,7 \\ \text { Centro-Oeste } & 6.041,50 & 6.041,50 & 100 \\ \text { Sudeste } & 1.174,40 & 53 & 4,5 \\ \text { Sul } & 291,5 & 291,5 & 100 \\ \text { Total } & 48.230,30 & 11.805,20 & 24,5 \\ & & & \\ & \text { Área Total por Região (2004- } & \text { Área INCRA Por Região 2004- } & \text { \% Área INCRA 2004-15 } \\ \text { Norte } & 2015) & 15 & 33,8 \\ \text { Nordeste } & 78.237,44 & 26.407,70 & 31,1 \\ \text { Centro-Oeste } & 83.267,75 & 25.916,80 & 98,9 \\ \text { Sudeste } & 6.447,93 & 6.374,60 & 42,1 \\ \text { Sul } & 5.169,65 & 2.178,70 & 100,0 \\ \text { Total } & 1.500,77 & 1.500,80 & 35,7\end{array}$


FAMILIAS BENEFICIADAS

$\begin{array}{lrcc}\text { Região } & \text { Total (1995-03) } & \text { INCRA (1995-03) } & \text { \% INCRA (1995-03) } \\ \text { Norte } & 3904 & 574 & 14,7 \\ \text { Nordeste } & 1934 & 0 & 0,0 \\ \text { Centro-Oeste } & 1162 & 0 & 0,0 \\ \text { Sudeste } & 360 & 0 & 0,0 \\ \text { Sul } & 0 & 0 & 0,0 \\ \text { Total } & 7360 & 574 & 7,8\end{array}$

$\begin{array}{lccc} & \text { Total (2004-07) } & \text { \% INCRA (2004- } \\ \text { Norte } & 518 & 99 & 07) \\ \text { Nordeste } & 1951 & 310 & 19,1 \\ \text { Centro-Oeste } & 0 & 0 & 15,9 \\ \text { Sudeste } & 32 & 0 & 0,0 \\ \text { Sul } & 0 & 0 & 0,0 \\ \text { Total } & 2501 & 409 & 0,0 \\ & & & 16,4\end{array}$

$\begin{array}{lccc} & \text { Total (2008-11) } & \text { INCRA (2008-11) } & \text { \% INCRA (2008- } \\ \text { Norte } & 910 & 192 & 21,1 \\ \text { Nordeste } & 1180 & 314 & 26,6 \\ \text { Centro-Oeste } & 28 & 28 & 100,0 \\ \text { Sudeste } & 12 & 0 & 0,0 \\ \text { Sul } & 117 & 117 & 100,0 \\ \text { Total } & 2247 & 651 & 29,0\end{array}$

$\begin{array}{lccc} & \text { Total }(2012-15) & \text { INCRA (2012-15) } & \text { \% INCRA (2012-15 } \\ \text { Norte } & 329 & 0 & 0 \\ \text { Nordeste } & 3658 & 2027 & 55,4 \\ \text { Centro-Oeste } & 619 & 619 & 100 \\ \text { Sudeste } & 124 & 124 & 100 \\ \text { Sul } & 139 & 139 & 100 \\ \text { Total } & 4869 & 2909 & 59,7 \\ & & & \\ \text { Norte } & \text { Famílias Total } 1995-15 & \text { Famílias INCRA 1995-15 } & \% \text { INCRA } \\ \text { Nordeste } & 5.661 & 865 & 15,3 \\ \text { Centro-Oeste } & 8.723 & 2.651 & 30,4 \\ \text { Sudeste } & 1.809 & 647 & 35,8 \\ \text { Sul } & 528 & 124 & 23,5 \\ \text { Total } & 256 & 256 & 100,0 \\ & 16.977 & 4.543 & 26,8\end{array}$


Recursos orçamentários e financeiros

\begin{tabular}{|c|c|c|c|c|}
\hline lespesas Correntes & $2004-2007$ & $2008-2011$ & $2012-2015$ & $2004-2015$ \\
\hline Previsto & $\mathrm{R} \$ 13.389 .511,00$ & $\mathrm{R} \$ 33.507 .130,00$ & $\mathrm{R} \$ 21.500 .000,00$ & $\mathrm{R} \$ 68.396 .641,00$ \\
\hline utc & R\$ 12.626 .9 & $\mathrm{R} \$ 22.976 .738,00$ & $367.592,41$ & $.300,41$ \\
\hline Valores Pagos & R\$7.401.283,00 & $\mathrm{R} \$ 11.654 .069,00$ & $\mathrm{R} \$ 10.782 .842,22$ & $\mathrm{R} \$ 29.838 .194,22$ \\
\hline
\end{tabular}

$\begin{array}{lcrrr}\text { Despesas de Capital } & 2004-2007 & 2008-2011 & 2012-2015 & 2004-2015 \\ \text { Previsto } & \text { R\$ 74.740.581,00 } & \text { R\$ } 160.071 .111,00 & \text { R\$ 125.000.000,00 } & \text { R\$ 359.811.692,00 } \\ \text { Autorizado } & \text { R\$40.248.512,00 } & \text { R\$51.948.472,00 } & \text { R\$ 128.799.009,70 } & \text { R\$ 220.995.993,70 } \\ \text { Valores Pagos } & \text { R\$4.838.517,00 } & \text { R\$35.570.411,00 } & \text { R\$ 26.707.562,28 } & \text { R\$ 67.116.490,28 }\end{array}$


ANEXO B - Registro Fotográfico

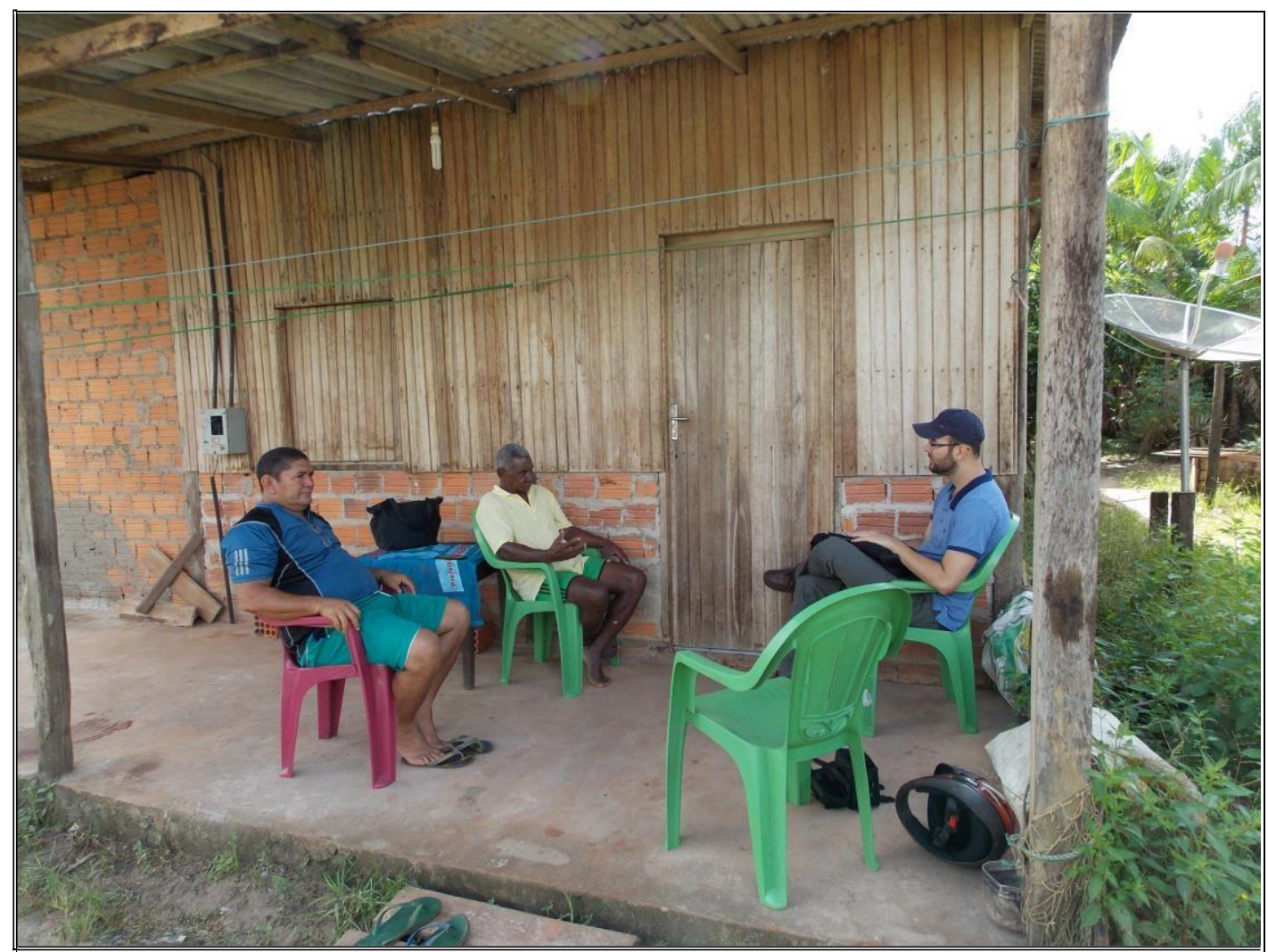

Na cidade de Calçoene, com o Sr. Eronildo (esquerda) e Sr. Domingos (centro).

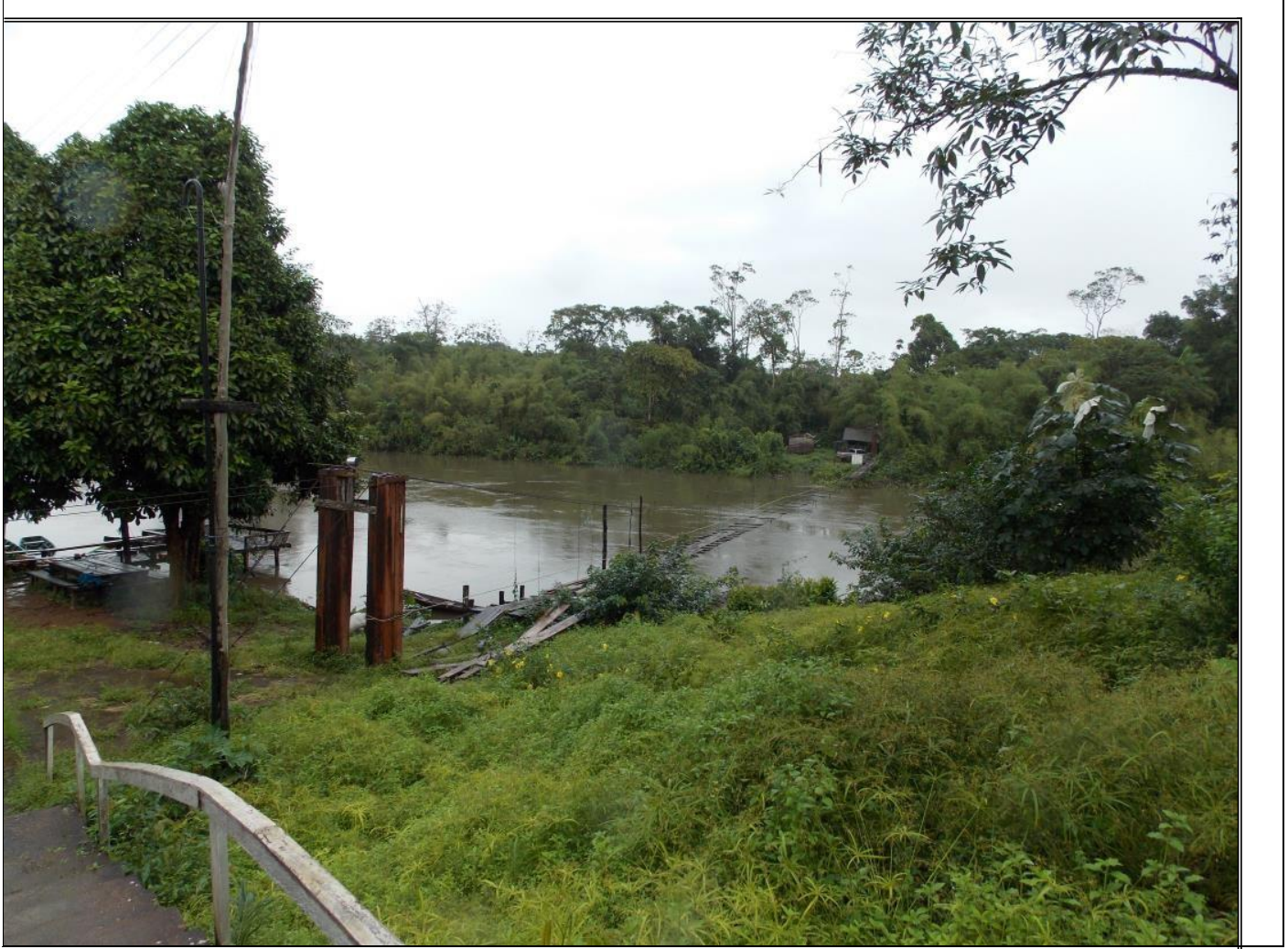

Vila de Cunani. Ponte sobre o rio Cunani. 


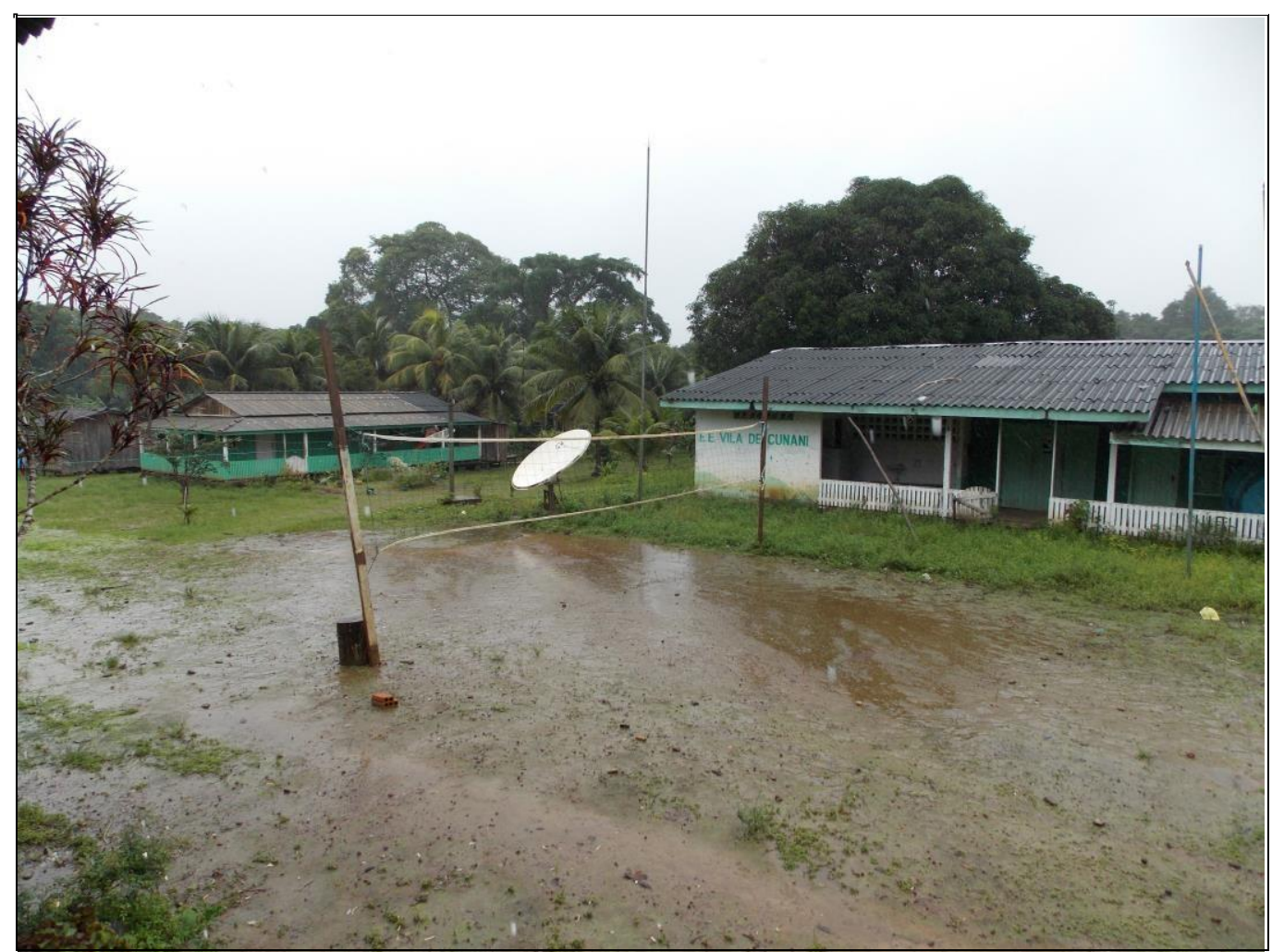

Vila de Cunani - Vista Geral

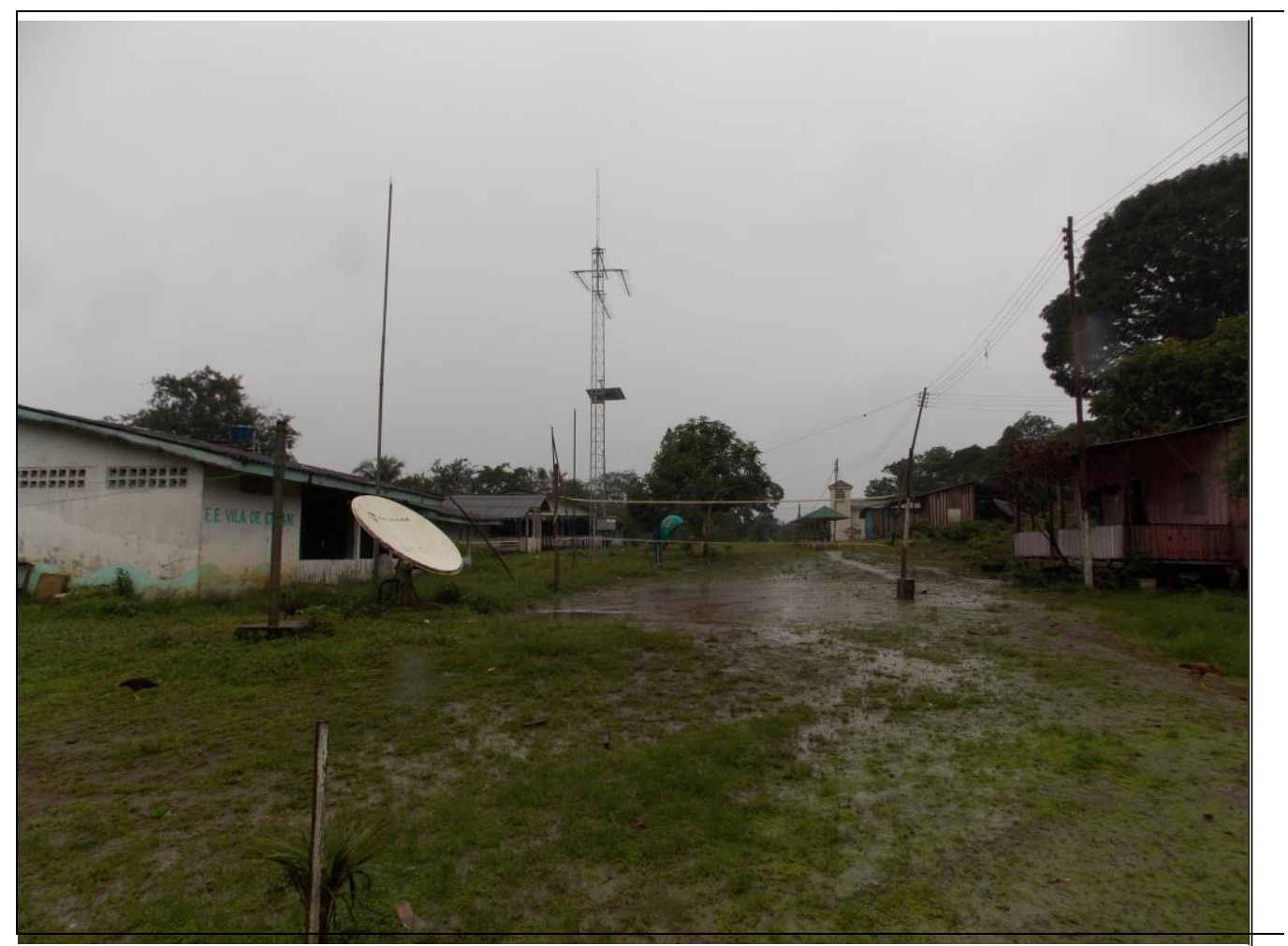

Vila de Cunani - Vista Geral. 


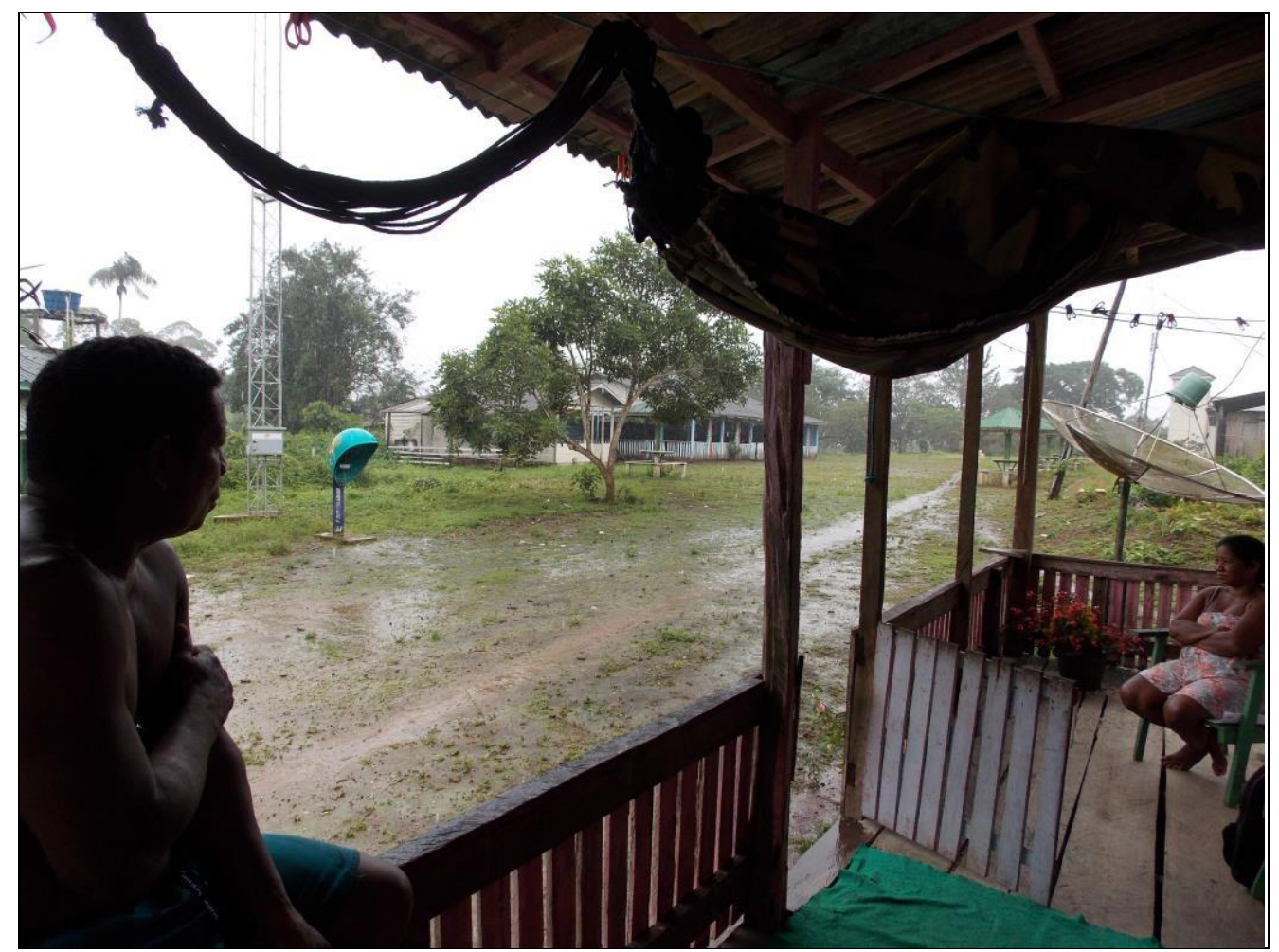

Sr. Amâncio e Sra. Rosineia. Vila de Cunani.

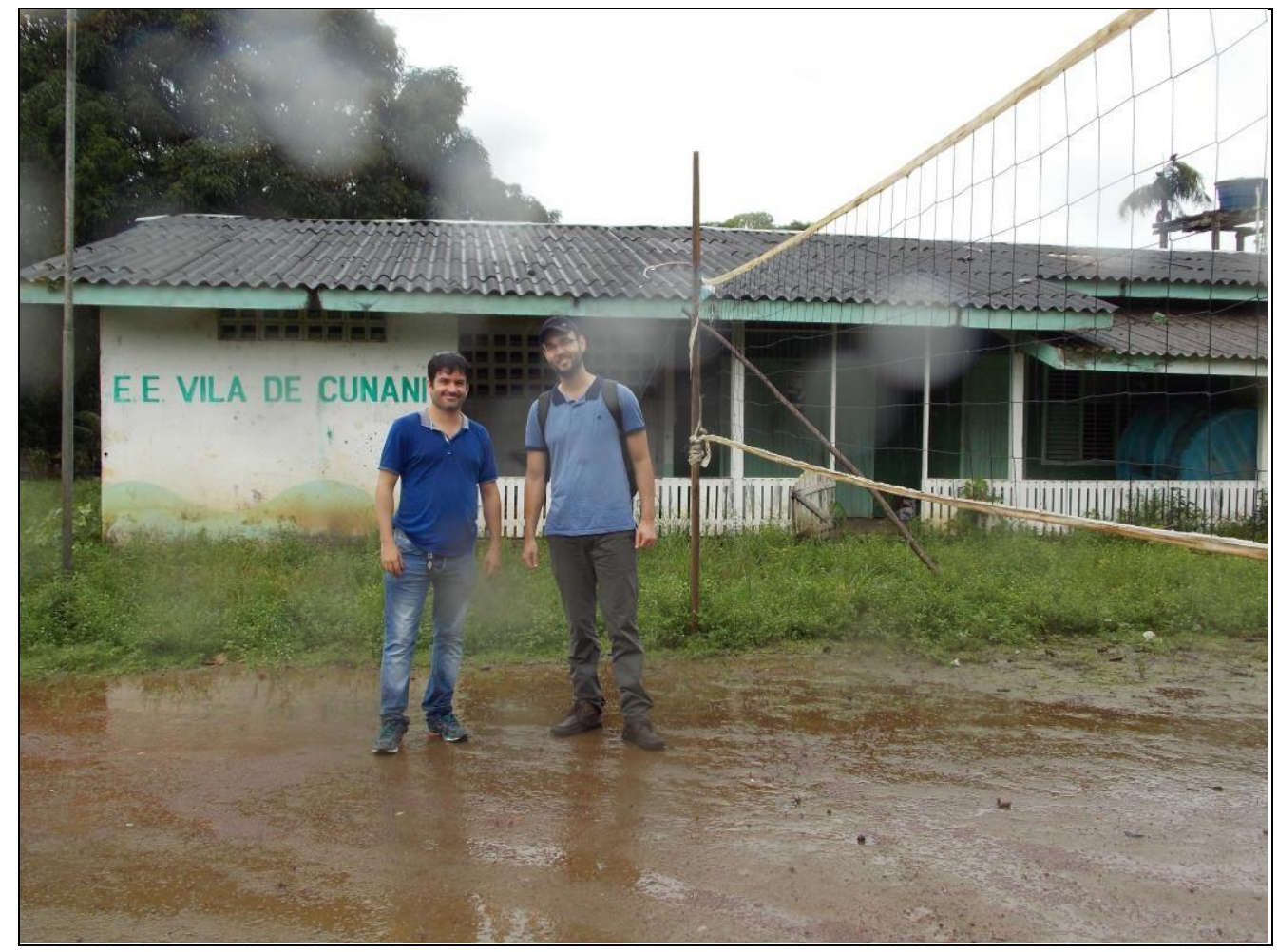

E.E. Vila de Cunani 